\title{
Samarbeid om selvhjelp
}

En antologi om den nye selvhjelpsbevegelsen i Norge

Ånund Brottveit og Marte Feiring (red.) 
Samarbeid om selvhjelp 

Ånund Brottveit og Marte Feiring (red.)

\section{Samarbeid om selvhjelp}

EN ANTOLOGI OM DEN NYE SELVHJELPSBEVEGELSEN I NORGE 
(C) 2019 Ånund Brottveit, Marte Feiring, Nora Gotaas og Hilde Hatleskog Zeiner.

Dette verket omfattes av bestemmelsene i Lov om opphavsretten til åndsverk m.v. av 1961. Verket utgis Open Access under betingelsene i Creative Commons-lisensen CC-BY 4.0 (http://creativecommons.org/licenses/by/4.0/). Denne tillater tredjepart å kopiere, distribuere og spre verket i hvilket som helst medium eller format, og å remixe, endre, og bygge videre på materialet til et hvilket som helst formål, inkludert kommersielle, under betingelse av at korrekt kreditering og en lenke til lisensen er oppgitt, og at man indikerer om endringer er blitt gjort. Tredjepart kan gjøre dette på enhver rimelig måte, men uten at det kan forstås slik at lisensgiver bifaller tredjepart eller tredjeparts bruk av verket.

Boka er utgitt med støtte fra OsloMet - storbyuniversitetet.

ISBN trykt bok: 978-82-02-64657-8

ISBN PDF: 978-82-02-59046-8

ISBN EPUB: 978-82-02-63254-0

ISBN HTML: 978-82-02-64872-5

ISBN XML: 978-82-02-64873-2

DOI: https://doi.org/10.23865/noasp.68

Dette er en fagfellevurdert antologi.

Omslagsdesign: Cappelen Damm AS

Forsidebilde: ARTQU/iStock/Getty Images Plus. Bildet er brukt med tillatelse fra Getty Images, og er ikke omfattet av CC-BY 4.0-lisens. Bildet kan ikke gjenbrukes uten tillatelse fra Getty Images.

Cappelen Damm Akademisk/NOASP

noasp@cappelendamm.no 


\section{Innhold}

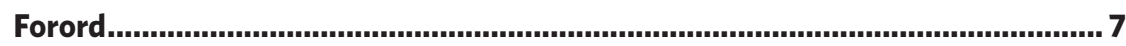

Kapittel 1 Den nye selvhjelpsbevegelsen .......................................................9 Anund Brottveit, Nora Gotaas, Hilde Hatleskog Zeiner, Marte Feiring

Kapittel 2 Selvhjelpsgrupper og behandlingsgruppers tilnærming til personlig endring - hva er likt og ulikt?

Anund Brottveit

Kapittel 3 Fra frivillig arbeid til folkehelsearbeid - om politisering av selvhjelpssaken .69

Marte Feiring

Kapittel 4 «Midt i smørøyet»- samarbeid og ambivalens i grenseflater mellom profesjons- og erfaringskunnskap 91 Nora Gotaas

Kapittel 5 Nasjonal selvhjelpssatsing møter lokalsamfunnet. 115 Marte Feiring

Kapittel 6 Rom for selvhjelp. Sosialt entreprenørskap og offentlig-frivillig samarbeid. 139

Ånund Brottveit

Kapittel 7 Fra felt til verktøy: Om Selvhjelp Norge som koordinerende enhet 167

Hilde Hatleskog Zeiner

Kapittel 8 Selvhjelp i grenseland - en ny type helsebevegelse? 191 Anund Brottveit, Marte Feiring, Hilde Hatleskog Zeiner 



\section{Forord}

Med denne antologien avslutter vi 10 års forskning innen det vi omtaler som den nye selvhjelpsbevegelsen i Norge. Vi startet opp dette prosjektet ved Norsk institutt for by- og regionforskning (NIBR, i dag del av SVA/ OsloMet) med forskningsmidler fra Helsedirektoratet våren 2009, og mottok midler i fem år. Mye av denne forskningen er formidlet tilbake til selvhjelpsfeltet i form av foredrag, seminarbidrag og rapporter. Vi har her valgt å samle denne forskningen og sette den inn i en mer akademisk sammenheng. En del av denne forskningen er også et doktorgradsprosjekt (Gotaas 2019) ${ }^{1}$ som er under ferdigstilling. De første årene av forskningsprosjektet arbeidet vi sammen med to andre norske miljøer, Lærings- og mestringssenteret i Volda og Høgskolen i Nord-Trøndelag (nå Nord universitet). Vi takker for interessante seminarer i dette nettverket som også hadde bred internasjonal deltakelse med nestoren innen feltet, Thomasina Borkman. Vi utvidet etter hvert antallet forskere i vårt prosjekt fra to til fire, og av medforfatterne i denne boka er det to antropologer, en sosiolog og en statsviter. Publiseringen av antologien er finansiert av forfatternes institusjoner, først av NIBR, deretter OsloMet og KIFO, Institutt for kirke-, religions- og livssynsforskning. En stor takk til alle gruppedeltakere og lokale selvhjelpsaktivister som har vært svært åpne og lagt forholdene til rette for forskerne. Vi takker samtidig de sentrale selvhjelpsaktørene, med hovedvekt på kompetansesenteret Selvhjelp Norge, for å åpne opp for tilgang til ulike deler av selvhjelpsvirksomheten og for et mangeårig samarbeide. Innholdet i denne antologien er ene og alene forfatternes ansvar.

Oslo, mai 2019

Marte Feiring og Ånund Brottveit

1 Nora Gotaas (2019, under ferdigstilling): «Takk for tilliten». Gjensidighet, transformasjon og rituell grammatikk $i$ selvorganiserte selvhjelpsgrupper. Manus til ph.d-avhandling, Sosialantropologisk institutt, Universitetet i Oslo 



\title{
KAPITTEL 1
}

\section{Den nye selvhjelpsbevegelsen}

\author{
Ånund Brottveit \\ KIFO - Institutt for kirke-, regions- og livssynsforskning
}

Nora Gotaas

By- og regionforskningsinstituttet NIBR, OsloMet - Storbyuniversitetet

Hilde Hatleskog Zeiner

By- og regionforskningsinstituttet NIBR, OsloMet - Storbyuniversitetet

\section{Marte Feiring}

Fakultet for helsevitenskap, OsloMet - Storbyuniversitetet

\begin{abstract}
In order to provide a background for subsequent discussions, the chapter introduces the notion of the "new self-help movement" in Norway. The 1980s and 90s saw the establishment of self-help groups that differed from more traditional approaches, such as Alcoholics Anonymous and other 12-step groups. The new self-help movement, we argue, cannot be understood independently of broader social developments. The chapter, therefore, discusses the self-help movement in light of recent welfare reforms and processes of individualization more generally. Developments in the new Norwegian self-help movement is part of a larger, international trend. Internationally, as well as in Norway, new self-help groups increasingly have a psychological and therapeutic orientation. Our aim, however, is not to contribute to the growing literature on causes and effects of the "therapeutic" or "self-help culture". Rather, our interest lies in collective, group-based forms of selfhelp. We argue that the context for group-based self-help activities has changed, and that this, in turn, changes the content and form of contemporary self-help groups and movements. We then proceed to introduce the theoretical framework on which the various contributions draw, and, finally, to introduce the various contributions.
\end{abstract}

Keywords: self-help groups, social movements, welfare reforms, individualization, boundary objects, politicization, social fields

Sitering av dette kapittelet: Brottveit, Å., Gotaas, N., Zeiner, H. H. \& Feiring M. (2019). Den nye selvhjelpsbevegelsen. I Å. Brottveit \& M. Feiring (Red.), Samarbeid om selvhjelp. En antologi om den nye selvhjelpsbevegelsen $i$ Norge (s. 9-46). Oslo: Cappelen Damm Akademisk. https://doi.org/10.23865/noasp.68.ch1

Lisens: CC BY 4.0 
Den nye interessen for selvhjelpsgrupper i Norge har sitt utspring i grupper og organisasjoner som etablerte seg på 1980- og 90-tallet. Ved siden av de «rene» selvhjelpsorganisasjonene etablerte også flere interesseog brukerorganisasjoner selvhjelp som et tilbud til sine medlemmer. Felles for disse organisasjonene er at de stod på to ben, hvor interessepolitikk utgjorde det ene benet og selvhjelp det andre (Zeiner, 2014). De nye selvhjelpsgruppene og organisasjonene kom ikke til fortrengsel for tradisjonelle selvhjelpsgrupper som Anonyme Alkoholikere (AA). ${ }^{1}$ I stedet opplevde også AA og lignende grupper som fulgte AA sin 12-trinnsmetode, en oppblomstring de siste tiårene før årtusenskiftet. I løpet av en relativt kort periode økte dermed både antallet selvhjelpsgrupper og variasjonen i tilbudet.

Angstringen er kanskje det tydeligste eksempelet på fremveksten av en ny form for selvhjelpsgrupper. Den første angstringen ble startet opp i 1986, og utviklet seg etter hvert til et nettverk av selvorganiserte selvhjelpsgrupper (angstringer). Inspirert av empowerment-ideer og terapeutiske prinsipper fra psykoterapien utviklet angstringene sine egne arbeidsformer og prinsipper for gruppesamtaler. Stiftelsen Angstringen Norge ble etablert for å drive informasjonsarbeid og nettverksarbeid med lokale angstringer. Til forskjell fra brukerorganisasjonene prioriterte Angstringen individrettet terapeutisk aktivitet i gruppene fremfor å drive interessepolitikk. Angstringen kan således stå som et tidlig eksempel på den innoverrettede dreiningen i det vi kaller «den nye selvhjelpsbevegelsen». Dette er trekk som kjennetegner selvhjelpsaktøren Selvhjelp Norge,

1 En rekke 12-trinnsgrupper, i og utenfor rusfeltet, ble etablert i denne perioden, så som Anonyme Narkomane, Anonyme Overspisere, Anonyme Gamblere og Al-anon (for pårørende til alkoholikere). Kjernen i disse gruppene er 12-trinnsprogrammet, som tilpasses deltakernes avhengighetsproblem, enten det dreier seg om avhengighet til alkohol, et narkotisk stoff, mat, spillavhengighet eller pårørendes medavhengighet. Til sammen utgjør de 12 trinnene en måte å leve livet på som starter med å innrømme at en har et problem, deretter oppsøker hjelp, utarbeider et personlig og moralsk regnskap, gjør opp for seg og ender med å arbeide for at andre rusavhengige skal kunne komme seg ut av sitt misbruk (Vederhus, 2011). I likhet med Angstringen har også disse gruppene først og fremst et terapeutisk formål. De skiller seg imidlertid fra den nye generasjonen selvhjelpsgrupper i sin vektlegging av anonymitet. Mens den nye selvhjelpsbevegelsen gjerne markedsfører sin virksomhet utad, har 12-trinnsorganisasjonene som prinsipp ikke å delta i offentlig debatt eller motta noen form for offentlig støtte. De oppfordrer også sine medlemmer til å bevare sin anonymitet i offentligheten. Felles for AA og den nye generasjonen selvhjelpsgrupper er deltakernes forpliktelse til å bevare andre deltakeres anonymitet. 
som på mange måter er den nye selvhjelpsbevegelsens «ektefødte barn» i dag. Selvhjelp Norge er samtidig et eksempel på en ny organisasjonsform, en mellomting mellom en statlig institusjon og en sivilsamfunnsaktør. Analytikere forbinder slike nye organisasjoner med styringsformer som er karakteristiske for et sen-moderne og post-velferdsstatlig liberalt samfunn² (Rose \& Miller, 1992).

\section{Selvhjelp sammen med andre}

Denne boken handler om den nye selvhjelpsbevegelsen i Norge; om hva som skjer i selvhjelpsgruppene, i lokalsamfunnet, i møtet med sivilsamfunnsaktører og profesjoner, og i samarbeidet med lokale og nasjonale myndigheter. Fremveksten av selvhjelpsbevegelsen kan ikke sees uavhengig av den mer generelle samfunnsutviklingen, men må forstås i lys av velferdsreformer og individualiseringsprosesser i samfunnet mer generelt. De nye selvhjelpsgruppene i Norge følger en internasjonal trend (Pistrang, Barker \& Humphreys, 20o8). Den psykologiserende og terapeutiske orienteringen til de nye gruppene samsvarer med utviklingstrekk i andre vestlige land (Illouz, 20o8; Oka \& Borkman, 200o).

Vårt bidrag er ikke primært et innlegg i debatten om årsaker og virkninger av det som har blitt kalt «den terapeutiske kultur» eller «selvhjelpskulturen» (Brinkmann, 2015; Illouz, 2008; Kroken \& Madsen, 2016; Madsen, 2010, 2014). Det er den kollektive, gruppebaserte formen for selvhjelp vi har i fokus, ikke den selvsentrerte trenden med selvhjelpsbøker og rådgivning basert på «positiv psykologi»(Seligman, 2006). Med begrepet «sosial bevegelse» (Goodwin, Jasper \& Polletta, 2001) som innfallsvinkel antyder vi at konteksten for selvhjelpsarbeid har endret seg sammenlignet med tidligere former for kollektiv selvhjelp, både med henblikk på arbeiderbevegelsen og den mer religiøst forankrede AA-bevegelsen. Det er nettopp fordi konteksten har forandret seg, at vi må forvente at nye sosiale bevegelser vil være annerledes enn de gamle. Vi finner det også interessant å analysere hvordan et fenomen som i starten er løselig

2 Begrepet «post-velferdsstatlig» betyr ikke avvikling av velferdsstaten, men at premisser om offentlig ansvar og finansiering svekkes i den politiske diskursen samtidig som sparepolitikk, markedsbaserte løsninger og offentlig-frivillig samarbeid introduseres. 
organisert og diffust formulert, blir institusjonalisert, politisert og profesjonalisert. Den nye selvhjelpsbevegelsen har utviklet et gradvis tettere samarbeid med offentlige aktører, noe vi forstår i lys av mer generelle politiserings- og profesjonaliseringsprosesser.

Selv om den nye selvhjelpsbevegelsen i hovedtrekk har representert en dreining fra sosialpolitisk virksomhet til en mer innoverrettet, terapeutisk virksomhet, så har den samtidig vært mer utoverrettet når det gjelder å søke ulike samarbeidsallianser innen hjelpeapparatet og offentlige institusjoner. Vi argumenterer for at dette er et trekk som best forklares med endringer i retning av en post-velferdsstatlig styringsform - det som Foucault kalte overgangen fra «government» til «governance» eller «governmentality» (Foucault, 1991).

I norsk velferdspolitikk skjedde dette i en periode preget av en nedbygging og desentralisering av psykiatriske institusjoner, samtidig som brukermedvirkning, samfunnspsykiatri, frivillighet og «tredje sektor» ble honnørord i politisk retorikk. Opptrappingsplanen for psykisk helse på 1990-tallet innebar en ny politisk og finansiell satsing på forebyggende tiltak og samarbeid med aktører i sivilsamfunnet. I forlengelsen av denne satsingen kom også en egen støtteordning for selvhjelpsprosjekter. Da var allerede stiftelsen Norsk selvhjelpsforum etablert, en ny type selvhjelpsorganisasjon som ble «moderorganisasjonen» til Selvhjelp Norge.

Siden Selvhjelp Norge har blitt en sentral aktør, premissleverandør og viktig promotør av en psykologisk inspirert selvhjelpsgruppemodell, vil mye av denne boken dreie seg om nettopp denne organisasjonen. Formålet med Selvhjelp Norge - et kompetansesenter, som i starten var organisert som et prosjekt - var å samle og videreformidle kunnskap om selvhjelp, samt å bidra til at lokale selvhjelpsgrupper og selvhjelpshus kunne etableres. Selvhjelp Norge er ikke en medlemsorganisasjon og er heller ikke selv «drivere» av selvhjelpsgrupper. Som kompetansesenter har Selvhjelp Norge imidlertid formidlet nokså klare oppfatninger om hvordan selvhjelpsgrupper bør organiseres og arbeide, og det har bidratt med informasjonsmateriell og kursholdere. Selvhjelp Norge har også formidlet kontakt til personer som grunnet egen erfaring og engasjement har kunnet fungere som «igangsettere» for lokale grupper. 
Selvhjelp Norge har på mange måter vært en vellykket virksomhet, fordi den ved hjelp av statlig støtte har fått stor innflytelse innen det vi kaller «selvhjelpsfeltet», fordi den har utviklet en innovativ halvoffentlig organisasjonsform, og fordi den har formulert og videreformidlet en moderne og tilsynelatende «tidsriktig» modell for selvhjelpsgrupper. Selvhjelp Norge har gjennom sitt hovedkontor, sine distriktskontorer og sitt nettverk av selvhjelpsfrivillige bidratt til en oppblomstring av aktivitetene på selvhjelpsfeltet. Likevel er det en del ting i dette bildet som skurrer: Flere samarbeidspartnere har falt ifra, og mange av selvhjelpsorganisasjonene foretrekker å drive for seg selv, uten å søke samhold under Selvhjelp Norges «paraply».

Den «nye» selvhjelpsbevegelsen, representert ved Selvhjelp Norge, samler ikke hele selvhjelpsbevegelsen slik intensjonen opprinnelig var. Flere av bidragene i denne boken registrerer friksjon når det gjelder lokale samarbeidsbestrebelser og når det gjelder sentral definisjonsmakt. Hva er «selvhjelp» og hva er en «selvhjelpsgruppe»? Svarene er mer omstridt enn en utenforstående kunne ane. Striden om definisjonene handler også om makten til å definere. Organisasjonskamp og faglig uenighet kan ikke skilles helt ifra hverandre.

Begrepet «selvhjelp» har blitt inngående kommentert og analysert i media og faglige publikasjoner, og da særlig den «selvopptatte» individorienteringen. En utbredt tolkning av denne nye opptattheten av selvhjelp er at det er et uttrykk for en selvsentrert kultur besatt av selvforbedring (Illouz, 2008). Observatører ser spor av denne selvhjelpskulturen både i måten vi organiserer våre private liv på (Madsen, 2010, 2014) og i måten vi organiserer samfunnet på (se bidrag i Kroken \& Madsen, 2016). Selvhjelpsbøker med oppskrifter på økonomisk suksess og et lykkelig samliv, og medienes økende vekt på såkalt «du-journalistikk», blir gjerne fremhevet som kjennetegn ved denne kulturen. Hos disse observatørene er det selvhjelpskulturens skyggesider som tematiseres. Det dreier seg ikke bare om en tendens til å individualisere strukturelle problemer, men om en «narsissistisk» kultur som gjennomsyres av konsumpsjon, individualisering, psykologisering og jakt på enkle løsninger (Illouz, 2008; Madsen, 2010).

Den nye selvhjelpsbevegelsen har selv en annen tolkning, selv om den også representerer en psykologiserende vending. Men i motsetning til 
selvhjelpslitteraturens fokus på ferdige "oppskrifter», så vektlegger den nye selvhjelpsbevegelsen troen på egen erfaringskunnskap og gjensidig kunnskapsdeling. Det er også en vektlegging av egne krefter og et håp om å vende en vanskelig situasjon. Selv om det kan være et forholdsvis sterkt fokus på egne følelser og indre psykologiske prosesser, så er det likevel en insistering på at dette skal fortolkes i en kollektiv setting, ved hjelp av andre mennesker i en gruppesetting. Selvhjelpsgruppen er et forpliktende kollektiv. Deltakere vil også hevde at støtten fra et gruppefellesskap er viktig, men at læreprosessene som kan oppstå i gruppene er minst like viktig. Både læring og selvutvikling finner sted innenfor en kollektiv ramme.

Den sosiale settingen gjør en vesentlig forskjell, tror vi. Erfaringskompetansen hentes ut av deltakernes egen livserfaring og deles gjennom samtalene og gjennom de felles opplevelsene som skapes i gruppen. Dette er noe helt annet enn å se tv-programmer om selvhjelp, lese selvhjelpsbøker eller få råd via nettsider. Ifølge den nye selvhjelpsbevegelsen kan selvhjelp like gjerne dreie seg om kollektiv frigjøring som individuell frigjøring - men middelet er den kollektive organiseringen.

I tidligere historiske kontekster har organiserte kollektive selvhjelpsgrupper vokst frem av behov og interesser som ikke var dekket på andre måter. Laug, fagforeninger og lignende er tidlige eksempler på lokalt organiserte, selvstyrte grupper som målbar prinsippet om hjelp til selvhjelp i møte med strukturendringer i samfunnet. Før velferdsstaten tjente de et todelt formål: De tilbød økonomisk, praktisk og moralsk støtte, og de bidro til en bevisstgjøring og politisering av medlemsmassen (Katz \& Bender, 1976, s. 270). Solidaritetsprinsippet var basert på gjensidig støtte mellom likepersoner, ikke paternalistisk hjelp fra velmenende makthavere. I denne tradisjonen kan brukerorganisasjoner, kvinnebevegelsen og den amerikanske borgerrettsbevegelsen alle forstås som selvhjelpsbevegelser (Borkman, 1999).

Både den kritiske og den positive tolkningen av fenomenet «selvhjelp» ser det i sammenheng med «tidsånden», og begge knytter selvhjelp til individualiseringsprosesser i samfunnet - enten som «medskyldig» i den, eller som et forsøk på å «reparere» virkningene av den. Dagens selvhjelpsgrupper kan, som de to tolkningene ovenfor viser, forstås både som årsak til og svar på individualiseringen av samfunnet. 
Organisasjonsformen til Selvhjelp Norge kan også forstås som et tegn i tiden, i det at den er verken en ren frivillig eller en helt statlig organisasjon. Vi skal gi et kort riss av den historiske bakgrunnen for dette.

\section{En ny type selvhjelpsorganisasjon}

Selvhjelp er en utpreget sivilsamfunnsaktivitet. I motsetning til andre former for frivillighet, hvor forskere har identifisert nasjonale særpreg (se for eksempel Selle, Strømsnes \& Loga, 2018), er beskrivelsene av selvhjelp som aktivitet relativt like fra land til land (se for eksempel Borkman, 1999; Hjemdal, 1995; Karlsson, 2006; Matzat, 1992; Munn-Giddings \& Borkman, 2005). En mulig forklaring kan være at selvhjelpsgrupper krever relativt lite ressurser sammenlignet med andre former for frivillighet. Selvhjelpsgrupper er ikke direkte interessepolitiske eller innrettet mot tjenesteproduksjon. De kan formes og organiseres uten et større apparat. Det eneste som kreves er at to eller flere finner sammen, og velger å håndtere sine livsproblem sammen. Selvhjelpsgrupper er heller ikke medlemsbaserte, og utover de krav som stilles til deltakelse i gruppen, hefter det som hovedregel heller ikke andre forpliktelser ved deltakelse i en gruppe. Slike trekk ved selvhjelpsgruppene kan være en forklaring på at selvhjelp som aktivitet tilsynelatende er mindre farget av sin nasjonale kontekst enn andre former for frivillighet. Matzat $(1992,2002)$ har for øvrig identifisert at selvhjelpsgrupper er mer utbredt i protestantiske enn i katolske land.

Videre har vi sett en viktig forskjell mellom selvhjelpsfeltet i Norge og internasjonalt. I motsetning til andre land har Norge en nasjonal plan som fastsetter mål og ambisjoner for selvhjelpsarbeidet. Planen er, som vi skal se, frukten av et samarbeid mellom en offentlig aktør og en sivilsamfunnsaktør. Dette samarbeidet er unikt, og i mange land ville det sannsynligvis også være utenkelig med et slikt samarbeid. At det vokser fram i Norge, skyldes nok i stor grad entreprenørskap; at noen har sett verdien av, og drevet fram, et partnerskap mellom stat og sivilsamfunn (Brottveit, 2012). Samtidig er dette en videreutvikling av en kjent modell. Norge, og Norden for øvrig, er kjennetegnet av høy grad av tillit til staten, 
og har en lang tradisjon for samarbeid mellom offentlige og frivillige aktører om utvikling av velferdstjenester og tilbud (Selle et al., 2018; Trägårdh, 1997). Andre land har valgt andre tilnærminger, som passer bedre med deres organisering av velferdstjenester og tilbud. I Tyskland, for eksempel, er selvhjelpsgrupper inkludert i sosialforsikringssystemet (Matzat, 2002). I det følgende vil vi se på hvordan samarbeidet mellom Norsk selvhjelpsforum og helsemyndighetene er vokst frem.

Oppblomstringen av selvhjelpsgrupper i Norge fra 1980-tallet og utover førte til økt offentlig oppmerksomhet rundt fenomenet selvhjelp. Samtidig opplevde flere av selvhjelpsaktørene at de hadde et behov for erfaringsutveksling og nettverksbygging. Fra midten av 1990-tallet ble det gjort forsøk på å etablere flere nettverk eller samarbeidsprosjekt mellom brukerorganisasjoner, frivillige, profesjonelle og offentlige aktører.

Studiesenteret for selvhjelp, et treårig forsøks- og forskningsprosjekt ved Norges kommunal- og sosialhøgskole (i dag en del av OsloMet Storbyuniversitetet), tok initiativ til det første, vidtfavnende forsøk på nettverks- eller relasjonsbygging på feltet, nemlig seminarrekken «Selvhjelp på norsk» i 1995. Andre eksempler er samarbeidsgruppen «På egne vegne», som hadde sitt utspring i Sosial- og helsedepartementets arbeid med Opptrappingsplanen for psykisk helse og Nasjonalt egenkraftsenter (NEKS), som ble forsøkt etablert av en arbeidsgruppe bestående av Voksne for barn, Interessegruppa for kvinner med spiseforstyrrelser (IKS), Landsforeningen for pårørende innen psykisk helse, Anorexia-Bulimia Foreningen, Mental Helse og Norsk selvhjelpsforum (NSF). Sistnevnte organisasjon skilte seg imidlertid ut fra de øvrige organisasjonene, noe vi skal komme tilbake til.

Norsk offentlig politikk og styringsideologi var fra 1980-tallet og utover preget av et mer positivt syn på markedsløsninger, rollen til sivilsamfunnsorganisasjoner og hensyn til brukerperspektiver. Målstyring og andre elementer i det som gjerne kalles New Public Management (NPM) ble innført for å rasjonalisere og begrense kostnadene forbundet med de rause velferdsordningene som fremdeles kjennetegner de skandinaviske landene. På bakgrunn av denne samfunnsutviklingen kan man godt si at myndighetene hadde behov for nye «partnere» i sivilsamfunnet, spesielt når det gjaldt forebyggende arbeid innenfor helse- og sosialsektoren. 
Norsk selvhjelpsforum (NSF) ble stiftet i 1998 av personer med bakgrunn fra arbeid i Angstringen og skal være et «nasjonalt kompetanse- og ressurssenter for bruk av selvhjelp» (Feiring, 2013; NSF, 2000). NSF har fra starten av mottatt finansiering fra ulike prosjekter som har vært rettet mot kunnskapsinnhenting og videreformidling om selvhjelpsarbeid. Stiftelsen Helse og Rehabilitering, som årlig utdeler midler til forsknings-, utviklings- og rehabiliteringsprosjekter har, ved siden av Oslo kommune, vært en viktig finansieringskilde.

NSF har gradvis blitt knyttet sterkere til det statlige styringsapparatet for helse- og sosialsektoren gjennom engasjementer og oppdrag for direktorat og departement. Årsmeldingene avspeiler samtidig en gradvis nedtrapping av nettverksarbeidet innenfor sivilsamfunnsorganisasjonene. Den prioriterte arbeidsoppgaven i $2001 \mathrm{om}$ «(u)tvikling av samarbeidet med de frivillige organisasjonene (lokalt og nasjonalt)» (NSF, 2002) har i 2002 blitt erstattet med et punkt om at det er «også nødvendig å arbeide med informasjons- og kunnskapsformidling mot ulike deler av tjenesteapparatet og offentlig sektor» (NSF, 2003).

Det er NSF som får oppgaven med å utarbeide et første utkast til en «Nasjonal plan for selvhjelp» for Sosial- og helsedirektoratet i $2001 \mathrm{og}$ 2002. Folkehelsemeldingen Resept for et sunnere Norge (Helsedepartementet, 2003) viser til denne foreløpige planen, og bidrar på denne måten til å gi selvhjelpsgruppene økt anerkjennelse. Helsedirektoratet inviterer imidlertid inn flere av de andre aktørene på selvhjelpsfeltet til å gi innspill, før de lager en endelig versjon av «Nasjonal plan for selvhjelp» i 2004 (Sosial- og helsedirektoratet, 2004). Dette indikerer et viktig gjennomslag for den nye selvhjelpsbevegelsen og at NSF har fått en helt sentral rolle. Samtidig illustrerer det at den nye organisasjonen ikke oppfattes som et representativt talerør for hele selvhjelpsfeltet. De ideologiske og strukturelle spenningene forbundet med NSFs og senere Selvhjelp Norges (SN) sentrale posisjon er som nevnt et tema vi vil vie mer oppmerksomhet $\mathrm{i}$ denne boken.

Da «Nasjonal plan for selvhjelp» ble lansert, signaliserte man i styringsdokumentet at selvhjelpsfeltets store mangfold var problematisk (Sosial- og helsedirektoratet, 2004). Som et virkemiddel i utviklingsarbeidet lanserer planen derfor forslag om å etablere «et knutepunkt for 
selvhjelp» som skal koordinere informasjons- og nettverksarbeid. Etter en utlysning fikk NSF i oppdrag å drifte det nasjonale knutepunktet i form av prosjektorganisasjonen Selvhjelp Norge. Selvhjelp Norge ble senere etablert som et nasjonalt kompetansesenter med NSF som eier og Helsedirektoratet som oppdragsgiver. Selvhjelp Norge ble altså opprettet i 2006, som et statlig virkemiddel, for å nå målsettingene i den nasjonale planen for selvhjelp om at «alle i Norge skal vite hva selvorganisert selvhjelp er, og hvordan de kan ta dette verktøyet i bruk når livsproblemer oppstår» (Helsedirektoratet, 2014, s. 6).

Selvhjelp Norge samarbeider offisielt med AA og 12-trinnsbevegelsen, med bruker- og interesseorganisasjonenes selvhjelpstilbud og med de frivillige organisasjonene, men Selvhjelp Norge blir ikke den samlende paraplyorganisasjonen som den var intendert å være. Som vi vil vise i denne boken, kan noe av årsaken være ideologisk. Selvhjelp Norges apolitiske policy om å ikke drive rettighetskamp bryter med interesseorganisasjonenes holdning om at dette er mulig og ønskelig å kombinere. Dette er samtidig mer på linje med AA og 12-trinnsbevegelsens tradisjonelle prinsipp om å aldri uttale seg offentlig om samfunnsspørsmål. På den annen side skiller Selvhjelp Norge seg markant ifra AA-bevegelsen når det gjelder sitt nære forhold til myndighetene. Det faktum at Selvhjelp Norge er fullfinansiert av staten og har et positivt syn på å samarbeide med direktorater, departementer og andre offentlige instanser for å utbre og promotere sin selvhjelpsmodell og filosofi, bryter med AA sitt konsekvente prinsipp om fullstendig autonomi overfor myndigheter og at de ikke tar imot offentlig støtte. På dette punktet er bruker- og interesseorganisasjonene derimot mer på linje med Selvhjelp Norge, idet at de gjerne ser på staten som en sponsor og kan godt delta som samarbeidspartner i offentlige helsekampanjer.

Etter noen års drift endrer Selvhjelp Norge status, fra å omtale seg selv som et knutepunkt til å bli et kompetansesenter. Fra 2010 starter oppbyggingen av Selvhjelp Norges landsomfattende nett av distriktskontorer. Distriktskontormodellen legger opp til nettverksbygging lokalt og styrking av det lokale arbeidet, men signaliserer samtidig en ambisjon om sterkere sentral styring av de lokale initiativene. Selvhjelp Norge beskriver «distriktskontorene som en forlenget arm» (Selvhjelp Norge, 2012, s. 36). 
Selvhjelp Norge er en prosjektorganisasjon med egne ansatte og er i likhet med moderorganisasjonen Norsk selvhjelpsforum (NSF) ingen medlemsorganisasjon. Vi ser her en ny type organisering som på grunn av sin sterke tilknytning til myndighetene ligger i et grenseland mellom staten og sivilsamfunnet. Denne organisatoriske innovasjonen følger en trend i sen-moderne og post-velferdsstatlig offentlig styring, omlegging til mer indirekte styring og delegering av oppgaver og ansvar til sivilsamfunnet. Vi reiser spørsmål om denne trenden ikke også skaper strukturelle spenninger innenfor selvhjelpsfeltet. Spenninger som avspeiles i ideologiske konflikter - noe vi finner indikasjoner på i de langvarige definisjonsstridene om hva «selvhjelp» er og skal være.

\section{Selvhjelp og velferdsstaten}

Den norske velferdsstaten er et eksempel på «den nordiske modellen», kjennetegnet av sjenerøse og samtidig universelle og individbaserte ordninger. Vi har rett til ytelser som borgere, ikke bare som arbeidstakere eller kjøpesterke konsumenter. Rettighetene er i hovedsak individuelle, ikke indirekte ved at familieforsørgeren er medlem av en jobbrelatert forsikringsordning eller har kjøpt helseforsikring på det åpne markedet. Den nordiske modellen er på samme tid mer individrettet og mer statlig enn kontinentaleuropeiske og nordamerikanske modeller (Trägårdh, Selle, Henriksen \& Hallin, 2013).

Mot bakgrunn av velferdsstatens ekspansjon kan oppblomstringen av selvhjelpsgrupper og selvhjelpsrelatert virksomhet virke paradoksal. Likevel er utviklingen av den moderne selvhjelpsbevegelsen fra 1930-tallet og utover nært forbundet med utviklingen av velferdsstaten. Den nye selvhjelpsbevegelsen kan, ifølge Feiring (2014; Kuhnle \& Solheim, 1991), «knyttes til en velferdsstat i krise og en begynnende omstillingsprosess med større verdsetting av sivilsamfunnets organisasjoner og aktiviteter». På 1970- og 80-tallet ble spørsmål knyttet til velferdsstatens grenser for alvor satt på dagsorden. Det var en erkjennelse av at velferdsstaten verken kan eller bør løse alle problemer, men at også sivilsamfunnets organisasjoner og aktiviteter vil måtte spille en rolle i utviklingen av samfunnets velferdsordninger. Denne erkjennelsen sammenfalt med fremveksten av 
det vi i dag omtaler som empowerment-tankegangen og kampen for å bedre marginaliserte gruppers livsvilkår og rettigheter (se Feiring kapittel 3 i denne boken). Forståelsen av en velferdsstatlig krise ledet til en rekke reformer og omlegginger som blir betegnet som post-velferdsstatlige.

Fra midten av 1990-tallet og utover har omstruktureringen av velferdsstaten i økende grad vært inspirert av New Public Management (NPM) (Christensen, Lægreid, Roness \& Røvik, 2009). Styringsmodellene og finansieringsordningene har fått et sterkere innslag av markedsmekanismer og styringsidealer hentet fra det private næringslivet. I Norge har den reformfasen som velferdsstaten er inne i, medført at det offentlige har påtatt seg et større ansvar for borgernes helse og velvære, samtidig som oppgaver delegeres nedover og enkeltindividets og lokalsamfunnets ansvar artikuleres tydeligere (Vike, 2004). Denne tendensen er fremtredende i senere års offentlige politikk og retorikk. Vi ser for eksempel at samhandlingsreformen har gitt kommunene et stort ansvar for sine innbyggeres helse og velvære, gjennom en folkehelsepolitikk som «skal fremme befolkningens helse, trivsel, og de sosiale og miljømessige forhold og bidra til å forebygge psykisk og somatisk sykdom, skade eller lidelse, bidra til utjevningen av sosiale helseforskjeller og bidra til å beskytte befolkningen mot faktorer som kan ha negativ innvirkning på helsen». ${ }^{3}$ I andre sammenhenger er man opptatt av å få frem innbyggernes medansvar. I Stortingsmeldingen «Morgendagens omsorg» heter det for eksempel at et «sterkt velferdssamfunn kan bare skapes sammen med innbyggerne. Det må bygges på tillit til at folk selv vil ta ansvar og delta aktivt i fellesskapet, ikke bare gjennom offentlige ordninger, men ved å stille opp og utgjøre en forskjell for hverandre i det daglige» (Helse- og omsorgsdepartementet, 2013, s. 12).

Likeså er begrunnelsen for NPM-reformer todelt. På den ene siden er reformene økonomisk motivert (jf. Clayton \& Pontusson, 1998). Etterkrigstidens optimisme, oppgangskonjunktur og store utvidelse av velferdstilbudene har siden 1970-tallet møtt flere tilbakeslag, økonomiske, $ø \mathrm{kt}$ arbeidsløshet, pessimisme, en aldrende befolkning og motstand mot å betale velferdsstatens økende utgifter over skatteseddelen. Reformene 
er dermed delvis et svar på krav om effektivisering og modernisering av offentlig sektor. På den annen side har flere reformer vært begrunnet $\mathrm{i}$ ønsket om en styrking av brukernes makt gjennom tiltak for brukermedvirkning og valgfrihet. Hvorvidt de faktisk er egnet til å realisere denne målsettingen er imidlertid omstridt. En del samfunnsforskere har i senere tid viet mye oppmerksomhet til nye former for statlig styring og vært ivrige til å påpeke at en tilsynelatende deregulering, demokratisering og markedstilpasning har gitt opphav til nye styringslogikker (Dean, 2006; Rose \& Miller, 1992). Innføringen av kravspesifikasjoner, rapporteringskrav, godkjente kvalitetssikringssystemer og sertifiseringsregimer har samtidig gitt staten like stor kontroll og påvirkningsmulighet som tidligere, hevdes det. Dette gjelder ikke bare for private selskaper og ikke-statlige organisasjoner, men også borgerne - hva enten i egenskap av å være markedskonsumenter eller tjenestebrukere. «Valgfrihet» er blitt et viktig politisk slagord, og brukermedvirkning og autonomi viktige honnørord. Baksiden av medaljen kan være at de nye brukerrettighetene og understrekingen av pasientautonomi også flytter ansvar over på brukerne/pasientene. Retten til å velge sykehus eller behandlingsform kan også bli en ansvarsfraskrivelse fra myndighetenes side og kanskje en illusorisk frihet. Valgfrihet forutsetter at den enkelte kan gjøre «informerte valg», det forutsetter både god informasjon, forståelse av denne og evnen til å velge.

Den nye selvhjelpsbevegelsen kan forstås både som et produkt av og en reaksjon på disse omstillingene i velferdsstaten. Ifølge Hjemdal (1996) er det ikke først og fremst motstand mot velferdsstaten eller misnøye med velferdstilbudet som har gitt grobunn for nye selvhjelpsorganisasjoner og -grupper, men snarere de mer overordnede sosiale og kulturelle strømningene som preger vår tid. Det dreier seg om endringer i sosiale relasjoner, i relasjonen mellom lekkunnskap og profesjonell kunnskap, og mellom stat og sivilsamfunn. Som vi har sett inngår empowerment, likestilling, autonomi og individets ansvar også i den nye selvhjelpsbevegelsens repertoar. Det handler om grensene for det offentlige ansvaret og de profesjonelle løsningene, om sivilsamfunnets og det sosiale nettverkets ansvar og ressurser og om betydningen av frivillig engasjement og gjensidig støtte. Et fellestrekk ved denne sammensatte motstandsbevegelsen er at den i større grad enn å reise politiske krav, peker på alternative verdier 
og ber om anerkjennelse av nye former for lidelse. Bevegelsen er svært heterogen og bæres ikke frem av én kollektiv identitet, men like fullt krever den og tilbyr for sine deltakere nye egendefinerte identiteter. De nye identitetene beskrives som myndiggjorte, handlende, ikke bare behandlede, overlevende etter overgrep eller lange sykdomsforløp, og hovedpersoner i egne liv.

Den nye selvhjelpsbevegelsen kan forstås som et motkulturelt fenomen. Høgsbro (1992) kaller den nye selvhjelpsbevegelsen en sivilisasjonskritisk strømning; en motstrøm kjennetegnet av en bred, tverrpolitiske appell, et kritisk blikk på både stat og marked, og en diffus ideologisk orientering (se også diskusjon i Feiring, 2014). Vi kan, med andre ord, si at selvhjelpsbevegelsen både tar opp i seg og forholder seg kritisk til de politiske, sosiale og kulturelle strømningene som har bidratt til å omstrukturere velferdsstatens form og retning.

\section{Individualisering}

Vi ser at det finner sted en økt fristilling av individet, både i forhold til tradisjon, moralske forpliktelser innenfor sivilsamfunnet, arbeidsmarked og organisasjonstilhørighet, men også overfor offentlige organer og myndigheter. Individuell selvrealisering, karriereplanlegging, bevisste livsstilsvalg og personlig image-bygging er gjengangstema i ukeblader og løssalgsaviser. Idealet om «å realisere seg selv» kan imidlertid, som Beck (Beck \& Beck-Gernstein, 2002) skriver, fort oppleves som en «livstidsdom» i stedet for en «frihet». Prisen kan være betydelig økt usikkerhet, identitetsforvirring, framtidspessimisme og ulike psykiske problemer. Samtidig ser vi at nye sosiale bevegelser, som vektlegger identitet og henter energi fra deltakernes emosjoner, tilbyr et fellesskap som kan bøte på slike menneskelige kostnader (Goodwin et al., 2001).

Individualiseringen innebærer i tillegg økt vektlegging av selvkontroll og egenansvar. Frigjøringspotensialet er en av drivkreftene, men neppe den eneste. Utviklingen av den globale økonomien og den sen-moderne organiseringen av arbeidslivet, samt visse trekk ved den demografiske utviklingen, drar også i retning av økt individualisering. Mobilitet, livslang læring, endringskompetanse og fleksibilitet er positivt ladede ord 
i politiske diskurser, men vi mer enn aner at det også er en individuell kostnadsside her. Vi antar at denne samfunnsutviklingen kan frembringe nye typer utenforskap.

Tilstrømningen til ulike selvhjelpsgrupper kan forklares på flere måter. Den nye selvhjelpsgruppebevegelsen kan betraktes som et tegn på at en økende gruppe mennesker mangler en opplevelse av å mestre, eller finne seg til rette i samfunnet vårt. Det kan skyldes at det ytre prestasjonskravet er blitt sterkere, men det er også tenkelig at de selv legger lista høyere for seg selv enn hva tidligere generasjoner gjorde. Uansett forklaring synes skamfølelsen over å ikke lykkes å være den samme. I likhet med tidligere tiders selvhjelpsvirksomhet - fagforeningenes streike- og sykekasser og bøndenes lokale samarbeidsordninger og nasjonale samvirkeorganisasjoner - kan nåtidens psykologisk orienterte samtalegrupper betraktes som en slags beskyttelse mot omkostningene ved en bestemt samfunnsmodell.

Vår tids kultur har kanskje høyere sensitivitet enn tidligere overfor de psykiske belastningene som livet medfører. I det minste observerer vi en sterkere tendens til å tolke ulike livsproblemer i psykologiske termer. Samtidig er det mulig at så vel arbeidslivet som familielivet nå stiller større krav om psykisk balanse og overskudd. Nye kjønnsroller, sterkere vektlegging av samarbeidsevner og kommunikative ferdigheter, og tilsvarende lavere toleranse for sære og avvikende personlighetstyper, kan være begrunnet i så vel hvordan dagens arbeidsliv er innrettet som i nye idealer for privatlivene våre. Man kan mislike eller beklage dette, men det er trolig både feilslått og nytteløst å neglisjere det eller avfeie det som en individuell karakterbrist. «Selvhjelpskulturen» (Illouz, 2008) kan være et symptom på at noe er dysfunksjonelt i vårt samfunn, men det er ikke årsaken til det.

En side ved samtidskulturen som kommer ekstra tydelig frem i de nye selvhjelpsgruppene, er troen på følelseslivets autentisitet. Dyrkingen av det «autentiske mennesket» er ikke noe nytt, men har kommet i ulike former siden opplysningsfilosofenes tid. Etter Freuds bøker om betydningen av det irrasjonelle sjelslivet og etter en epoke der hans arv, det psykodynamiske paradigmet, dominerte i psykiatrien, finner vi fortsatt mye av dette tankegodset i populærkulturen og selvhjelpsgruppenes psykologiske 
forståelser. De emosjonelle, eventuelt kroppslige, reaksjonene fortolkes som budbringere for «dyptliggende» konflikter og disharmonier, og oppfattes som «sannere» enn det som sies med rene ord. Menneskers evne til forstillelse og selvbedrag betraktes som bortimot grenseløst, mens følelsene derimot ikke lyver. Det kan synes som om det indre sjelslivet og emosjonelle uttrykk har fått en videre betydning og nærmest ubestridelig autoritet som veiviser i eksistensielle og mellommenneskelige kriser. At vår «indre natur» nettopp er «natur». Antropologisk forskning, emosjonssosiologi og krysskulturelle psykologiske studier viser imidlertid en variasjon som peker i en annen retning, nemlig at emosjoner også er kulturelt formet - ikke bare uttrykksformene, men også deres kilder og konteksten de vanligvis opptrer $\mathrm{i}$.

Likevel er det kanskje nettopp i sin tilnærming til emosjoner og følelsesmessig bearbeiding at selvhjelpsgruppene har potensial til å være en motkultur i samfunnsutviklingen. Rett nok viser vår forskning at de nye selvhjelpsgruppene ofte legger svært stor vekt på tolkning av individuelle emosjoner. Her vil vi imidlertid peke på et annet poeng som kritikere av «selvhjelpskulturen» altfor ofte overser: Denne utforskingen skjer ikke i enerom, men i en flerstemmig sosial setting. Selvhjelpsgruppen er også en sosial kontekst - et sosialt mikrokosmos der deltakerne kan speile seg selv i de andre. Den mytologiske Narcissus ble forgapt i sitt eget speilbilde og ble ute av stand til å elske andre enn seg selv. Selvhjelpsgruppen, slik vi har erfart den gjennom forskningen vår, er svært langt fra et slikt passivt og ensidig bekreftende speil. Gruppen krever gjensidig speiling og interaksjon. En selvhjelpsgruppe er et forpliktende sosialt fellesskap, basert på gjensidighet og åpenhet, med samtale og selvrefleksjon som viktigste virkemidler. Det lyder derfor ikke helt urimelig når selvhjelpsgruppedeltakere omtaler dette som «arbeid». Faren for problemdyrking og selvnytelse lurer alle steder i dagens samfunn, selvhjelpsgrupper inkludert (Lasch, 1991). Men vi mener at de andres tilstedeværelse og den gjensidige moralske forpliktelsen kan demme opp for den narsissistiske faren.

Selvhjelpsgruppen representerer også et alternativt sosialt rom, et beskyttet «bakrom» der vi kan legge til side «fasaden» og finne støtte hos likemenn (Goffman, 1971). Vi finner det interessant at mange ser ut til å 
velge en selvhjelpsgruppe, sammensatt av «fortrolige fremmede», fremfor familie og venner, for å samtale om dypt personlige livsproblemer. I Goffmans (1971) teatermetafor for det moderne samfunnet er det offentlige rommet sammenlignet med en teaterscene hvor menneskene hele tiden må levere en presentasjon av seg selv i samsvar med allmenne forventninger og konvensjoner. Dette orker vi ikke i lengden, uten å ha et bakrom, en «back-stage», der vi kan gå ut av rollen og spøke og le sammen med våre lagkamerater. Her kan vi også trøste hverandre når det trengs. Goffman skrev om dette allerede på 1950-tallet, men behovet for et bakrom er neppe blitt mindre i et sen-moderne samfunnet som i økende grad tilbyr, eller krever, mer personliggjorte roller. Beck (Beck \& Beck-Gernstein, 2002) mener at denne utviklingen stiller oss overfor en mye mer krevende oppgave og at den moralske dommen overfor dem som mislykkes, også er blitt hardere, og mer ensom.

Det kan hende at vi ikke finner så lett lagkamerater i et arbeidsliv som preges stadig mer av usikkerhet og karrieretenkning. Det er også mulig at nye kjønnsroller og nye og mindre stabile samlivsformer gjør det mer krevende å forme en identitet og finne en god rolle i privatlivet. Endringer i kjønnsrollemønsteret har også medført en større overlapp i fritidsinteresser og vennenettverk til ektepar/partnere. Det kan bety at det potensielle bakrommet til det intime familielivet har blitt innskrenket - at det er blitt vanskeligere å finne fortrolige samtalepartnere som samtidig står utenfor familiens intimsfære. Til tross for at «gutteturer» og «syklubber» har hatt en viss renessanse, så kan det tenkes at selvhjelpsgruppene møter et voksende behov for en alternativ intim sosial setting i det sen-moderne samfunnet - et fellesskap som ikke er familie- eller kollegabasert, men som består av «fortrolige fremmede».

Individualiseringsprosessene i samfunnet kan ha gitt grobunn til en ny etterspørsel etter nye psykososiale tilbud - det som har blitt kalt nye «sosiale teknologier» (Dean, 2006) - for å hjelpe oss som enkeltindivider til å utvikle og realisere en fungerende identitet/rolle. Vi skal ikke bare ha en velfungerende identitet sosialt sett, men en identitet vi personlig kan leve med. Dette nye behovet vil, dersom det er et samfunnsmessig utbredt fenomen, på ulike måter bli artikulert og fange oppmerksomhet. Den nye selvhjelpsbevegelsen er en slik artikulering. 


\section{Politisering}

Fremveksten av de nye selvhjelpsorganisasjonene og statens rolle i denne utviklingen passer ikke helt inn i den samfunnsvitenskapelige standardteorien om sivilsamfunnets ønske om mer autonomi og myndighetenes sterke styringsvilje og -evne. Dette kan henge sammen med at statens rolle i de nordiske landene trolig har vært annerledes enn i andre vestlige land og at det hersker et spesielt tillitsforhold mellom borgerne og staten (Trägårdh, 1997). Denne formen for tillit forklarer hvorfor et samarbeid med staten ikke alltid oppleves som å være statsstyrt. Utviklingen av den fullt ut statsfinansierte organisasjonen Selvhjelp Norge var, som nevnt, et klart brudd med den tradisjonen som Anonyme Alkoholikere hele tiden har fulgt. Selvhjelp Norge vil imidlertid hevde at de gjennom dette samarbeidet har satt selvhjelp på dagsorden og realisert et landsomfattende tilretteleggingsapparat for lokale selvhjelpsgrupper. Offentlig-frivillig samarbeid har skjedd på ulike nivåer, både sentralt, fylkeskommunalt og kommunalt. Disse eksemplene utfordrer den tradisjonelle forståelsen av selvhjelp som en ren sivilsamfunnsaktivitet, og reiser spørsmål om hvordan myndighetenes inntreden på selvhjelpsfeltet påvirker selvhjelp som idé og som verktøy. For en organisasjon som Selvhjelp Norge handler dette til en viss grad om å avgrense selvhjelp mot offentlige tjenester, mens det fra myndighetenes side handler om at en del av satsingen på psykisk helse, og folkehelsepolitikken mer generelt, overlates til en frivillig aktør.

Vi prøver å forstå utviklingen av den organiserte selvhjelpen, både fra et organisatorisk-politisk perspektiv og fra et kunnskapsteoretisk perspektiv. Selvhjelpspraksis har blitt gjort til en «sak» og løftet fra privatsfæren og inn i statsbudsjettet gjennom en flerfaset politiseringsprosess, der hver fase eller stadium har bidratt til større offentlig oppmerksomhet og sterkere grad av organisering. Latour har lansert et teoretisk perspektiv som ser på hvordan enhver «sak» kan bevege seg gjennom ulike faser eller stanse opp:

1: Nye, tidligere uomtalte, relasjoner mellom mennesker eller materielle objekter blir lagt merke til og identifiserer på den måten en ny «sak». Dette gjøres ofte av individer som vi omtaler som «sosiale entreprenører», fordi de identifiserer og navngir «noe» som ingen har gjort før dem; 
2: Mobilisering av en gruppe som deler interessen for eller ansvarsfølelsen for å gjøre noe med denne aktuelle «saken». Dette er kimen til en ny sosial bevegelse og til en ny kollektiv praksis - «saken» har blitt et felles anliggende for noen, og kan få organisatoriske uttrykk;

3: «Saken» får offisiell anerkjennelse ved at myndighetene anerkjenner dens gyldighet og sitt ansvar for å utforme en politikk. Dette innebærer et gjennomslag i offentligheten, samtidig som «saken» utsettes for politisk «styring» eller forsøk på dette;

4: Den nye «saken» blir så gjenstand for politisk debatt og politiske dragkamper, fordi den nå vil kunne utløse bindende politiske vedtak og ressursprioriteringer;

5: «Saken» har nå blitt anerkjent i en slik grad at den har blitt «løftet over» det politiske spillet, blitt rutinisert og avpolitisert.

(Harman, 2014; Heaney, 2015; Latour, 2008)

\section{Felt}

Vi bruker begrepet «selvhjelpsfeltet» om alle aktørene, praksisene og forståelsene som kan identifiseres og som deltar i forhandlinger om hva selvhjelp er. Det kan nok diskuteres hvor hensiktsmessig denne avgrensingen er i analytisk forstand: om alle de forskjellige praksisene og forståelsene som bruker ordet «selvhjelp» har tilstrekkelige fellesnevnere til å utgjøre et noenlunde felles felt, og å være et felt i seg selv. Vi kommer tilbake til dette i kapitlene, men her vil vi klargjøre litt hva vi forstår med begrepet felt.

Et felt i sosiologisk forstand (Bourdieu, 1977; Bourdieu \& Wacquant, 1992) impliserer at vi har aktører som deler en interesse om knappe goder og at de konkurrerer eller samarbeider for å tilegne seg disse. En selvhjelpsorganisasjon kan oppleves som en konkurrent til et nærliggende offentlig lærings- og mestringssenter som også tilrettelegger for selvhjelpsgrupper, fordi de rekrutterer fra den samme målgruppen. En brukerorganisasjon, som har selvhjelpsgrupper som en del av sin virksomhet, kan konkurrere med en «ren» selvhjelpsorganisasjon om å få disponere lokaler i et kommunalt bygg. Ulike aktører som alle ønsker å promotere selvhjelpsgrupper, kan kjempe om statlige midler til sin formidlingsvirksomhet. Den «knappe ressursen» kan med andre ord være ulike ting, og den kan også 
være av mer symbolsk art som synlighet i offentligheten og statlig anerkjennelse. Bourdieu bruker begrepet kapital om ressursene som «står på spill» i stridene på et felt, og understreker at dette omfatter mer enn penger. Bourdieu har, foruten økonomisk kapital (materielle goder), beskrevet sosial kapital (nyttige sosiale forbindelser), kulturell kapital (kompetanse) og symbolsk kapital (prestisje) (Jenkins, 1992, s. 85).

Det kan være at selvhjelpsfeltet, som vi her har avgrenset for en analyse, er del av et større felt. Selvhjelpsfeltet kan for eksempel være en del av et «for lokal helse- og velferdsproduksjon» som regulerer helse- og omsorgsvirksomhet i bredere forstand. Dette er delvis et empirisk spørsmål, avhengig av hva vi konkret finner i den sosiale konteksten, og delvis et spørsmål om hva som er hensiktsmessig gitt problemstillingen vi arbeider ut fra. Feltbegrepet gjør det lettere å forstå hvordan ulike aktører forholder seg til hverandre. Vi kan lettere forstå hvorfor noen aktører velger å samarbeide, mens andre kanskje motarbeider hverandre, og atter andre «melder seg ut», eventuelt blir definert ut (Bourdieu \& Wacquant, 1992; Fligstein \& McAdam, 2012).

I litteraturen finner vi ulike tilnærminger til feltbegrepet. Mens feltbegrepet i Bourdieus forståelse reserveres for etablerte og til en viss grad monopoliserte fenomener, som for eksempel «det psykiatriske felt», anvender Fligstein og McAdam (2012) feltbegrepet for å beskrive og forklare hvordan sosiale bevegelser vokser fram, vedlikeholdes og forvitrer. Et felt i Bourdieus forstand er kjennetegnet av gitte posisjoner og relasjoner, selv om det kan variere hvem som til enhver tid innehar de ulike posisjonene. Aktørene prøver også å forbedre sine posisjoner gjennom å allokere mer kapital. Fligstein og McAdam, på sin side, skiller mellom fremvoksende og etablerte felt. De vektlegger sterkere en dynamisk forståelse av felt, hvor posisjoner og relasjoner er et produkt av stadige forhandlinger og reforhandlinger. Et fremvoksende felt består av to eller flere aktører hvis handlinger er orientert mot hverandre, men hvor det ikke er etablert en orden som bidrar til å rutinisere interaksjonen mellom dem (Fligstein \& McAdam, 2012, s. 86)

Et felt er etablert når aktørene er i stand til å reprodusere seg selv og feltet over en lengre tidsperiode. Posisjonene og spillereglene er avklart, og aktørene har en felles referanseramme som gjør det mulig for dem 
å identifisere handlingsalternativer og å tolke de øvrige aktørenes handlinger (Fligstein \& McAdam, 2012, s. 86).

Fligstein og McAdams dynamiske feltforståelse innebærer også at blikket i økende grad rettes mot relasjoner mellom aktører innen ulike felt, særlig mellom sivilsamfunnsaktører og aktører på statlig nivå (Fligstein \& McAdam, 2012). Vi er derfor også opptatt av hvordan selvhjelp som fenomen fungerer som et grenseobjekt mellom frivillig og offentlig sektor, og mellom selvhjelpsaktører og det profesjonelle hjelpeapparatet.

\section{Sosialt entreprenørskap og grenseobjekter}

En langvarig trend i det moderne samfunnet har vært en profesjonalisering av en rekke samfunnsmessige funksjoner ved at disse har blitt omgjort til lønnet arbeid med krav til utdanning for den som skal utføre dem. «Frivillig arbeid» har vært definert ut fra hva det ikke er - ulønnet arbeid som ikke krever profesjonsutdanning. Utviklingen av velferdsstaten har skjedd ved at en rekke uformelle frivillige oppgaver har blitt gjort til statens ansvar og «profesjonalisert». I denne utviklingen har det også blitt identifisert nye behov og nye kategorier tjenestebrukere som ikke hadde eksplisitte tilbud tidligere. Sosialt entreprenørskap har ofte dreiet seg om nettopp dette - å identifisere og utforme svar på nye behov i befolkningen. Frivillig sektor i form av organisasjonene har ofte utviklet nye samfunnsinstitusjoner og tjenester som det offentlige senere har tatt ansvar for. En slik utvikling og formalisering av sosiale institusjoner, også omtalt som "politisering» (Latour, 2007), er med andre ord ikke noe nytt. Det er heller ikke rollen sosiale entreprenører kan spille i en slik prosess. Det er likevel noe som er nytt i den konteksten som den nye selvhjelpsbevegelsen oppstår innenfor.

Nordiske velferdsstater har lenge vært kjennetegnet av et tett samarbeid mellom stat og frivillighet (Selle et al., 2018; Trägårdh, 1997), og flere velferdsordninger har sitt utspring i frivillige initiativer som senere er blitt til statlige eller kommunale velferdsordninger (se blant annet Norske kvinners sanitetsforening, 1971; Stefansen, 2006). Fra 1980-tallet og utover har imidlertid staten tatt til orde for en annen form for, og annerledes begrunnet, samarbeid med frivilligheten, og oppmuntret 
til organiserte former for offentlig-frivillig samarbeid. Dette har vært begrunnet både økonomisk og ideologisk. Velferdsstaten har blitt kritisert både for manglende økonomisk bæreevne og for maktkonsentrasjon og formynderi. Det offentlige hjelpeapparatet og hegemoniet til den profesjonsbaserte kunnskapen har med dette blitt utfordret fra flere hold. Både av dem som har ønsket å slippe til private aktører og tilbud basert på alternative faglige tilnærminger, og fra dem som primært har ønsket en sterkere brukerstyring av egen behandling og i utformingen av de offentlige tjenestene.

De politiske regimene ble på 1980-tallet preget av en ny-liberal ideologi som promoterte en nedbygging av offentlige velferdsordninger, større ansvar til enkeltindivider og sivilsamfunn, og åpning for private, kommersielle tilbydere på helse- og sosialområdet. Man har forklart dette med at staten ikke lenger kan påta seg å levere tjenester på alle psyko-sosiale behov i befolkningen. I stedet kan staten ta en sterkere rolle som kvalitetssikrer. Staten eller kommunen kan bestille tjenester, og så vel offentlige tjenestetilbydere som humanitære non-profitt-tilbydere kan konkurranseutsettes. I denne nye politiske konteksten har det også blitt åpnet for å ta initiativ til hybride samarbeidskonstellasjoner med frivillige og kommersielle aktører. De offentlige myndighetene har i mange tilfeller begrenset seg til å være kvalitetssikrere. Standardkrav, regnskapsrutiner og vandelsattester aksepteres av frivillige og kommersielle aktører i bytte mot offentlige kroner, samfunnsoppdrag og offisiell legitimitet. De nye organisasjonsformene og relasjonstypene spenner i fra relativt formaliserte organisasjoner som aksjeselskaper og stiftelser til løsere samarbeidskonstellasjoner rundt enkeltprosjekter og sak-til-sak-samarbeid. Når slike innovasjoner finner sted på helse- og sosialområdet, blir det ofte betraktet som et resultat av sosialt entreprenørskap.

Sosialt entreprenørskap handler om å skape sosial verdi gjennom innovasjon, og er ofte drevet fram av sivilsamfunnsaktører, for eksempel sterkt engasjerte enkeltindivider som vi gjerne kaller «ildsjeler» (Lundgaard Andersen \& Hulgård, 2014, s. 35). Det er forbundet med en evne til å «lese» behov og mangler i samfunnet og til å forestille seg og realisere kollektive løsninger på disse behovene. Sosialt entreprenørskap 
kan ha en økonomisk betydning, men for den sosiale entreprenøren er det ikke den økonomiske bunnlinjen, men snarere den sosiale bunnlinjen som teller (Austin, Stevenson \& Wei-Skillern, 2006; Lundgaard Andersen \& Hulgård, 2014). Den sosiale entreprenøren kan være både kreativ og handlekraftig, og ikke minst i stand til å krysse oppgåtte grenser mellom samfunnssektorer og kulturelle domener. De nye løsningene innebærer innovative organisasjonsformer, nye samarbeidsrelasjoner og nye arbeidsmetoder (Barth, 1972; Førde \& Borch, 2010; Ingstad, 2009).

Den nye selvhjelpsbevegelsen har brakt med seg eksempler på organisasjonsdannelser, virksomhetsformer og forståelsesmåter som illustrerer sosialt entreprenørskap. 1980-tallet representerer samtidig en annen kontekst enn 1950-tallet, og dette gir andre forutsetninger for organisasjonsdannelse og posisjonering vis-à-vis myndighetene. Tradisjonelt har selvhjelpsbevegelsen, representert ved AA, lagt meget stor vekt på autonomi. Denne tradisjonen kan forklare noe av ambivalensen vi kan spore hos den nye selvhjelpsbevegelsen i sin relasjon til myndigheter og offentlige tjenester. Selvhjelp Norge har inngått et svært nært samarbeid med staten, men forsøkt å holde distanse til det profesjonelle hjelpeapparatet. Samtidig finner vi her et eksempel på en ny hybrid organisasjon, som både gir staten innflytelse på selvhjelpsfeltet og Selvhjelp Norge innflytelse på statens selvhjelpspolitikk. Selvhjelp Norge har samtidig et mer diffust samarbeid med de andre selvhjelpsorganisasjonene. Den diffuse samarbeidsformen er også et trekk i tiden, et fenomen noen teoretikere kaller «grenseobjekt».

Et grenseobjekt er et analytisk begrep for det som samarbeidende aktører deler, men som gjerne tolkes og beskrives forskjellig av de samme samarbeidspartene (Callon, 1984). De har imidlertid en felles interesse i dette objektet og er avhengig av samarbeid for å utnytte potensialet som det gir. Noen ganger kan objektet være et felles middel for å oppnå ulike mål, for eksempel ved at de deler en nettside, men promoterer ulike produkter eller agendaer. Andre ganger kan det tvert om være et felles mål som er grenseobjektet, men at partene likevel tolker målformuleringen forskjellig, de «oversetter» det ulikt. Star og Griesemer vektlegger grenseobjektets «plastisitet»: 
Boundary objects are objects which are both plastic enough to adapt to local needs and the constraints of the several parties employing them, yet robust enough to maintain a common identity across sites. (Star \& Griesemer, 1989, s. 393)

Selvhjelp Norge kan godt kalles et grenseobjekt (eller grenseorganisasjon), men vi vil her primært fremheve selvhjelpen som idé som et grenseobjekt. Grenseobjektet er i dette tilfellet den ideologiske fremstillingen av «selvhjelp i Norge». Selvhjelp Norge har hele tiden tatt mål av seg til å formidle innholdet av denne ideen til den norske offentligheten gjennom diverse kampanjer, til myndighetene gjennom møter og skriftlige dokumenter, til profesjonelle og til andre aktører på selvhjelpsfeltet gjennom brosjyrer, igangsetterkurs og konferanser, og til lokale selvhjelpsgrupper gjennom rådgivning, informasjonsmateriell og igangsettere. Selvhjelp Norge har på sett og vis forsøkt å ta «eierskap» til begrepet selvhjelp, men de har aldri forvaltet dette begrepet alene. Det finnes en rekke andre aktører som også driver en aktivitet de forstår som selvhjelp. Det kritiske spørsmålet er om den selvhjelpsideologien som Selvhjelp Norge har tatt mål av seg til å formulere, formidle og promotere på vegne av «alle» - om den i praksis deles og støttes av alle?

I Star og Griesemers klassiske eksempel på hva et grenseobjekt kan være i praksis, beskriver de samarbeidet mellom det vitenskapelige personalet på et zoologisk museum for virveldyr i California og blant andre en gruppe jegere. Museet var avhengig av innsamlet materiale av smågnagere, fugler, øgler og pattedyr tilhørende et avgrenset geografisk område hvor jegere drev mye jakt med feller og skytevåpen. For at materialet skulle ha verdi for museet, måtte det medfølge en rapport om habitat og tidspunkt i form av et utfylt standardskjema. Dette måtte ikke være for omfattende eller be om umulige opplysninger, skulle jegerne orke å fylle det ut på en samvittighetsfull måte. Det var også viktig at skjeletter og spesielt kranier var mest mulig intakte. Det fortelles at de måtte bruke mye tid på å få jegerne til å endre sin vante praksis med å avlive fangede eller skadede dyr ved å smadre hodet på dem. Dette innsamlingsarbeidet forståes som et grenseobjekt, og man kan godt si at det utviklede skjemaet også var et grenseobjekt. Det var et samarbeid mellom svært ulike aktører og på bakgrunn av svært forskjellige motiver - jaktinteresse og 
økonomisk kompensasjon versus vitenskapelig interesse og dokumentasjon av et naturlig habitatsområde. Samarbeidet skapte en grenseflate hvor det oppstod en felles interesse i å få det til å fungere for begge parter. Det ble også utviklet en felles identifikasjon med innsamlingsprosjektet fra begge parter, selv om utgangspunktet var svært ulikt. Star og Griesemers poeng er at dette ikke ville ha fungert dersom museet hadde stått ensidig på sine krav og behov uten å ta hensyn til den andre partens virkelighetsforståelse. En ensidig kommunikasjon er dømt til å feile. Det samme kan jo sies om jegerne, dersom de hadde avvist å fylle ut noen form for skjema eller insistert på å fortsette med å knuse hodeskaller. Det største ansvaret for å få dette til å fungere lå imidlertid på museets ledelse, siden dette hadde koordinatorfunksjonen, et "centre of authority» for grenseobjektet (Star \& Griesemer, 1989).

En selvhjelpsgruppe eller et lokalt selvhjelpshus (LINK) som kan huse og støtte flere selvhjelpsgrupper, kan også betraktes som grenseobjekter. I dagens kontekst synes etablering av selvhjelp, etter Selvhjelp Norges modell, å være avhengig av en rekke ulike støttespillere. En viktig forskjell fra tidligere tiders samfunnskontekst er en ny holdning til offentligfrivillig samarbeid og en kobling av ganske forskjelligartede organisasjoner, etater og private virksomheter om enkeltprosjekter. I forskningen har vi sett dette i etableringen av selvhjelpsgrupper i enkelte lokalsamfunn - ja, det synes som om det er nettopp dette som har vært avgjørende for å lykkes med etableringen.

Samarbeid om selvhjelp kan for en selvhjelpsorganisasjon bety hjelp til å få i gang flere selvhjelpsgrupper og til å spre informasjon til potensielle deltakere i lokalsamfunnet. For en offentlig samarbeidspart kan det bety å legge til rette for at deres tjenestebrukere finner en selvhjelpsgruppe og på den måten greier å ta mer egen-ansvar for sin egen helse og samtidig avlaste hjelpeapparatet. Begge parter kan enes om målformulering og virkemidler, selv om de kanskje har forskjellige motiver for å gå inn i dette samarbeidet, og betrakter det med ulike «briller». Måten «selvhjelp» beskrives på i felles dokumenter og informasjonsnettsider, må være generell og fleksibel nok til at alle parter kan identifisere seg med innholdet, samtidig som det gis rom for å konkretisere informasjonen slik at den blir anvendbar for egen kontekst. 
Det er en innebygget spenning mellom behovet for å standardisere grenseobjektet og behovet for fleksibilitet. Ofte vil en aktør innta en koordinerende rolle i samarbeidsrelasjonene rundt et grenseobjekt - det Star og Griesemer kaller autoritativt senter (Star \& Griesemer, 1989), som får en slags forvalterrolle. Et slikt autoritativt senter i et samarbeidsnettverk vil kunne utøve definisjonsmakt og vektlegge standardisering, på bekostning av fleksibilitet og andre aktørers ønsker. I Star og Griesemers eksempel var det museumsledelsen som fungerte som autoritativt senter.

Vårt utgangspunkt er at nye innovative organisasjoner ofte er resultat av sosialt entreprenørskap, og at de vil ofte ha kjennetegn som grenseobjekter. Hvilke potensielle fordeler og fallgruver innebærer det? Vi har allerede pekt på sosiale entreprenørers egenskaper når det gjelder å gå nye veier og krysse tradisjonelle barrierer. Evnen til å krysse grenser er spesielt «etterspurt» $\mathrm{i}$ en tid da nye grenseoverskridende organisasjonsformer for å løse samfunnsoppgaver ser ut til å «vinne terreng». Enten entreprenøren opererer på et lokalt eller nasjonalt nivå, har personlige nettverk ofte stor betydning i nyskapingsarbeid. Et bredt og sammensatt personlig nettverk er et godt utgangspunkt for å kunne «tolke sin egen tid» og «lese sitt eget lokalsamfunn». Fokuseringen på sosiale entreprenører kan gi enkeltindivider en overdrevet betydning. Selv om «ildsjeler» ofte kan være viktige utløsere, så er likevel sosialt entreprenørskap sjelden et «sololøp». Det er ikke tilfeldig at en forskningsartikkel om sosialt entreprenørskap har valgt tittelen «Ildsjelen og de gode hjelperne» (Borch \& Vestrum, 2010), fritt etter folkeeventyret om «Espen Askeladd og de gode hjelperne». Nettverket er ofte en viktig del av «løsningen», når entreprenøren først har identifisert et samfunnsproblem. En utfordring for den eller de som har spilt rollen som sosiale entreprenører kan være deres sterke eierskap til prosjektet. I Star og Griesemers artikkel understreker de viktigheten av fleksibilitet og hensyn til samarbeidspartnernes forskjellighet. De skriver at «imperialistiske innføringer» av bestemte definisjoner gjør at samarbeidet nødvendigvis mislykkes (Star \& Griesemer, 1989, s. 413-414). Det er i dette perspektivet vi vil granske selvhjelpsaktørenes - Selvhjelp Norge i særdeleshet - roller, innbyrdes relasjoner og definisjoner av selvhjelpsfeltet. 


\section{Forskning på selvhjelp}

Samfunnets økte interesse for selvhjelpsgrupper har også medført økt forskningsaktivitet. Lenge har denne forskningslitteraturen vært opptatt av individet, mens analyser av selvhjelp på gruppe-, organisasjons- og samfunnsnivå har vært mindre fremtredende (et unntak er Katz, 1993; se også Salem, 1996). Dette kan blant annet skyldes at forskningen i stor grad har fokusert på selvhjelpsgrupper som et alternativ eller komplement til offentlige velferdstjenester, gjerne ved at effekten av deltakelse i slike grupper sammenlignes med andre behandlingstilbud (Pistrang et al., 2008). Videre har den internasjonale forskningslitteraturen om selvhjelpsgrupper i stor grad vært fokusert på AA-grupper - som spesielt i USA har fått en særegen posisjon (Humphreys et al., 2004). Nyere forskning tar i større grad for seg andre grupper som ikke har avhengighetsproblematikk, men psykiske problemer og livsproblemer knyttet til sykdom, funksjonsnedsettelse eller dødsfall. Mye av denne forskningen er imidlertid knyttet til grupper initiert av det offentlige tjenesteapparatet. Selvledete selvhjelpsgrupper har det ikke blitt forsket like mye på, og en årsak til det kan være at slike grupper ikke registreres eller finansieres av myndighetene og derfor «går under radaren».

Organiseringen av selvhjelpsgrupper med tilknytning til det nasjonale kompetansesenteret Selvhjelp Norge, og det at den offentlige tilskuddsordningen åpnet for forskningsprosjekter, har gitt muligheter for en ny type selvhjelpsforskning. De mange nye selvhjelpsgruppene for «selvorganisert selvhjelp» og Selvhjelp Norges funksjon som bindeledd har åpnet for forskning på den nye generasjonen av psykologisk orienterte, men samtidig selvledete, selvhjelpsgrupper i en norsk kontekst. I tillegg til vårt eget forskningsprosjekt som vil bli presentert nærmere nedenfor, har det blitt drevet forskning med utgangspunkt i Høgskolen i Nord-Trøndelag og Høgskolen i Volda (Aglen, Hedlund \& Landstad, 2011; Hedlund \& Landstad, 2012; Stokken, 2015; Stokken, Barstad \& Thokle, 2012).

Forskningen på den nye selvhjelpsbevegelsen kompletterer annen selvhjelpsforskning som har studert AA-grupper (Vederhus, 2009, 2011; Vederhus \& Kristensen, 2006). Fokuset på bevegelsens organisatoriske og samfunnsmessige dimensjoner er en ny tilnærming, og måten staten nå 
involverer seg på selvhjelpsfeltet åpner også for helt nye problemstillinger (Zeiner, 2014).

To teoretiske perspektiver har vært særlig fremtredende i den senere tids forskning: Foucault-inspirerte tekstanalyser og en habermasiansk tilnærming. Den første ser statens engasjement i selvhjelp som et uttrykk for en medborgerteknologisk strategi, hvor staten gjennom å konstituere autonome og ansvarsfulle borgere kan redusere velferdsstatens kostnader (Hedlund \& Landstad, 2012; Lundgren, 2010). Den habermasianske tilnærmingen sidestiller, på sin side, statens engasjement på selvhjelpsfeltet med systemets inntreden i livsverden (Stokken et al., 2012). Felles for de to tilnærmingene er at de betrakter statens engasjement med et mistenksomt blikk, og spør om dette engasjementet medfører en dreining fra grasrotinitiativ til mer toppstyrte prosesser (Lundgren, 2010; Stokken et al., 2012; Zeiner, 2014).

I likhet med denne forskningen er vi i denne boken opptatt av hva som skjer på både gruppe-, organisasjons- og samfunnsnivå. Vårt utgangspunkt er likevel et litt annet. I likhet med Katz (1993) anvender vi begrepet sosiale bevegelser som inngangsport for å analysere ulike sider ved den nye selvhjelpsbevegelsen. Som vi har vært inne på over, kan målsettinger om empowerment danne et utgangspunkt for selvhjelpsgrupper og selvhjelpsorganisasjoner. Empowerment refererer både til en verdi, en målsetting og en tolkningsramme som tar opp i seg - og reagerer på - en rekke politiske, sosiale og kulturelle utfordringer på nye og ukonvensjonelle måter.

I sin bok konkluderte Katz likevel med at selvhjelp i USA ikke er en sosial bevegelse, til det er selvhjelpsfeltet for heterogent (1993). Utover verdier som gjensidighet og autonomi, samt viktigheten av erfaringsbasert kunnskap, har selvhjelpsorganisasjoner i liten grad samlet seg om felles verdier, overbevisninger eller solidaritet. I fravær av felles målsettinger, verdier eller ambisjoner har de heller ikke bygget nettverk. En viktig forskjell mellom selvhjelpsfeltet i USA på 1990-tallet og selvhjelpsfeltet i Norge på 200o-tallet er imidlertid at sistnevnte i langt større grad er organisert. Selvhjelp Norge var ment å være et koordinerende middel for en slik organisering og samordning av selvhjelpsfeltet. Det er likevel et spørsmål om det nasjonale kompetansesenteret Selvhjelp Norge kan sies å ha bidratt til en slik samling (Zeiner, 2014). 
Med utgangspunkt i dette spørsmålet ønsker vi i denne boken å danne et bilde av et fenomen som på mange måter fremstår som mer nyansert og mangefasettert enn det som gjerne formidles i den offentlige debatten. Vi betrakter Selvhjelp Norges virksomhet fra flere vinkler: fra innsiden av gruppene, fra samarbeid med lokale myndigheter og lokale organisasjoner, fra profesjonenes ståsted, fra Stortingsmeldinger, offentlige planer og andre dokument, og fra samarbeid med frivillige organisasjoner og andre selvhjelpsaktører. For å belyse dette fenomenet har vi valgt å benytte ulike teoretiske perspektiv for å forstå selvhjelp generelt og Selvhjelp Norges virksomhet mer spesielt. Vi nærmer oss spørsmålet om hvorvidt og hvordan selvhjelp kan sies å utgjøre en sosial bevegelse gjennom begrepene politisering, felt og grenseobjekt, og relaterer denne bevegelsens fremvekst til individualiseringsprosesser i samfunnet.

\section{Vårt bidrag}

I denne boken presenterer vi egen forskning som undersøker hvordan selvhjelp i de siste tiårene har økt kraftig i omfang og blitt et offentlig anliggende. Forskningen som presenteres her, ble startet i 2009 og datainnsamlingen har skjedd i perioden 2009-2014. Kapitlene i denne boken reflekterer de sentrale problemstillingene i forskningsprosjektet. Vi har lagt vekt på fire hovedtema: endrings- og mestringsarbeidet som foregår i gruppene, hvordan ulike instanser samarbeider for å legge til rette for selvhjelpsarbeid, forholdet mellom erfaringsbasert og profesjonsbasert kunnskap, og hvordan selvhjelp kan vokse fram i ulike typer lokalsamfunn. Ettersom prosjektet starter opp i 2009 og vi deretter søkte og fikk midler flere etterfølgende år, har forskningsspørsmålene gradvis blitt utvidet. Blant annet har vi kunnet gjøre studier av arbeidet knyttet til flere lokalsamfunn og i flere tilfeller fulgt prosesser over tid.

Kvalitativ metode er egnet til å gripe slike endringer. Generelt har vi vært på jakt etter å se sammenhenger mellom hvordan ulike aktører forstår selvhjelpsarbeid, hvilke strukturelle og ressursmessige betingelser som er til stede og hva slags form og føringer det gir til arbeidet. Vi har brukt intervjuer og dokumentanalyser, vært til stede som observatører på ulike typer møter og arrangementer, samt hatt en rekke uformelle 
samtaler med ulike aktører. Arbeid knyttet til selvhjelpsgrupper er særlig sensitivt og prosjektet er meldt inn til Personvernombudet for forskning, Norsk samfunnsvitenskapelig datatjeneste. I kapitlene redegjør vi kort for datainnsamlingen knyttet til hvert delprosjekt.

I samfunnsvitenskapene er informantene langt fra bare «objekter» som skal studeres, men folk som forskerne ofte er avhengig av å utvikle gode i samarbeidsrelasjoner med. Det var også en eksplisitt forutsetning fra Helsedirektoratets side. Vi har hatt en fortløpende dialog med de sentrale aktørene på feltet, Norsk selvhjelpsforum (NSF) og Selvhjelp Norge, og en relativt jevn tilbakeføring av resultater, i form av ett til to arbeidsmøter i året med NSF og Helsedirektoratet, foredrag og innlegg på konferanser og skriftlig rapportering. Dialogorienteringen overfor informanter er også fremtredende i delprosjektene. I forskning hvor man er ute etter folks forståelsesformer, er dette også en forutsetning for å få frem relevante og gyldige data. Disse forutsetningene fører samtidig til at relasjonen mellom informanter og forskere blir mer sammensatt enn tidligere og partene kan ha flere roller overfor hverandre.

Vårt utgangspunkt er at det vi kaller politiseringen av selvhjelp, har bidratt til at selvhjelp har blitt mer tydelig som fenomen, men samtidig vidtfavnende og uavgrenset. På tross av at vi med Selvhjelp Norge har et nasjonalt kompetansesenter, som skal bidra til å samle inn, bearbeide og spre kunnskap om selvhjelpsgrupper, betraktes likevel selvhjelp fra utsiden ofte som en usosial aktivitet; en aktivitet som fremhever individet på bekostning av fellesskapet. Men selvhjelp er også noe annet, nemlig «gjensidig hjelp» (Borkman, 1999), og det er den gjensidige formen for selvhjelp - det at mennesker kommer sammen for å arbeide med sine livsproblem - vi ønsker å utforske.

Dette, som vi kan kalle selvhjelpens kollektive dimensjon, underkommuniseres ofte i den offentlige debatten om selvhjelp. I stedet presenteres gjerne en forenklet og kanskje også karikert versjon av selvhjelp, hvor målet er å bli en bedre utgave av seg selv. Vi ser derfor behov for å beskrive og analysere selvhjelp som en gruppeaktivitet. Det finnes en kollektiv dimensjon i den nye selvhjelpsgruppebevegelsen, selv om de ikke vil opptre interessepolitisk. Vi begynner derfor denne boken med 
et innblikk i selvhjelpsgruppenes «indre liv» for å gi et innblikk i selve kjernevirksomheten i selvhjelpsarbeidet. I det første kapittelet, Selvhjelpsgrupper og behandlingsgruppers tilnoerming til personlig endring - hva er likt og ulikt?, ser Brottveit nærmere på selvhjelpsgruppenes arbeidsform, hva slags fellesskap en selvhjelpsgruppe er, og hva som skjer der. Kapittelet drøfter to hovedmodeller for selvorganiserte selvhjelpsgrupper og peker på en del felles «terapeutiske mekanismer» som også behandlingsgrupper gjør bruk av. Samtidig er det interessante forskjeller, ikke bare mellom gruppebehandling og selvhjelpsgruppene, men også mellom en 12-trinnsgruppe (for eksempel AA eller Anonyme Narkomane) og en «Selvhjelp Norge-gruppe». Selvhjelp Norge er mer psykologisk orientert og vektlegger personlig autonomi og selvkontroll, mens AA-grupper bygger opp under en kollektiv identitet samtidig som selvkontroll oppfattes som et illusorisk og umulig mål for en rusmisbruker.

Vi tar så et lite sideblikk på den historiske bakgrunnen for Selvhjelp Norges modell for selvorganiserte selvhjelpsgrupper. I kapittelet Fra frivillig arbeid til folkehelsearbeid - om politisering av selvhjelpssaken ser Feiring på hvordan selvhjelp omtales og oversettes i sentrale politiske og andre dokumenter. Hun viser hvordan selvhjelp redefineres i ulike tekster skrevet av politikere, fagfolk og aktivister. Ved hjelp av begrepet politisering ser hun på hvordan selvhjelpsaken beveger seg gjennom ulike politiske stadier, fra selvhjelp som frivillig arbeid, via selvhjelp som psykisk helsearbeid, til selvhjelp som folkehelsearbeid. Feiring konkluderer med at den nasjonale selvhjelpsvirksomheten i dag er betydelig mer politisert enn for tre tiår siden, samtidig som de mange selvhjelpsaktørene er mer fragmentert enn på lenge. Bildet som tegnes av selvhjelpsfeltet i Norge, støtter opp om de lokale eksemplene som blir belyst i boken, men settes her inn i en bredere historisk og teoretisk ramme.

Deretter beveger vi oss til selvhjelpsgruppenes omgivelser, til lokalsamfunnene og hvordan selvhjelpsarbeid har kommet i gang og blitt formet ulike steder og ut ifra ulike betingelser. Vi er samtidig på leting etter fellesnevnere som kan være med å belyse hvordan selvhjelpsarbeid mange steder er blitt promotert av «ildsjeler» som en form for «sosialt entreprenørskap» og hvordan nye samarbeidsrelasjoner rundt denne praksisen kan forstås som «grenseobjekter» eller «grense-organisasjoner». 
«Midt i smørøyet» - samarbeid og ambivalens i grenseflater mellom profesjons- og erfaringskunnskap. I dette kapittelet tar Gotaas utgangspunkt i et viktig spørsmål i selvhjelpsarbeid generelt: Hvilke roller kan fagfolk spille i forhold til en sosial praksis som i utgangspunktet er definert som en sivilsamfunnsaktivitet og en grasrotbevegelse? Et miljø av fagfolk i Vestfold, knyttet til lærings- og mestringssentrene, og delvis psykiatrien, etablerte et nettverk for å bygge opp selvhjelpsarbeid i fylket som blir karakterisert som svært vellykket. Samtidig var det tydelig preget av spenningsforhold mellom erfarings/lekkunnskap og fagkunnskap og mellom motstridende krav om fleksibilitet og standardisering. Vi får her en god illustrasjon av den innebygde spenningen i det vi omtaler som «grenseobjekter» - et felles anliggende som ulike aktører i et løst organisert samarbeid kan identifisere seg med. Vestfold-eksempelet brukes også som en inngang til å diskutere mer generelle utfordringer ved at selvhjelpsarbeid befinner seg i skjæringspunktet mellom profesjonelle tjenester og frivillig arbeid og hvordan dette kan håndteres.

Nasjonal selvhjelpsatsing møter lokalsamfunnet: I dette kapittelet analyserer Feiring et offentlig/sivilt samarbeid i forbindelse med utforming av lokale møteplasser for selvhjelpsaktivitet. Det er etablering av en regional og en lokal møteplass for selvhjelp i Østlandsregionen som settes under lupen. Samarbeidet utspiller seg mellom nasjonale selvhjelpsaktører og en bykommune. Prosessen analyseres gjennom ulike stadier: Oppstarten av samarbeidet innebærer konstituering av en felles sak som er målsettingen om en lokal møteplass for selvhjelp. Feiring diskuterer hvordan aktørene utformer grenseobjekter, som et grunnlag for fellesskap og felles identitet som forener dem på tvers ulike sosiale kontekster. Dette kommer til syne i hvordan aktørene «oversetter» sitt felles anliggende i skriftlige beskrivelser, i diverse planer og andre dokumenter. Feiring viser at utviklingen av fleksible grenseobjekter er av betydning for at et samarbeid mellom offentlige og sivile aktører skal fungere i praksis.

I kapittelet Rom for selvhjelp. Sosialt entreprenørskap og offentligfrivillig samarbeid beskriver Brottveit erfaringer med å opprette Norges andre LINK i en liten nordnorsk kommune. Brottveit peker på at en lokal «ildsjel», strategisk nettverksbygging, gode kommunikasjonskanaler og samtidig legitimering fra nasjonale aktører var tilsynelatende viktige 
faktorer. Etableringsprosessen belyses med teori om sosialt entreprenørskap og feltteori. Analysen har overføringsverdi til andre lokaliteter hvor folkehelseprosjekter forsøkes implementert og til forstålsen av entreprenørvirksomhet i lokale kontekster mer generelt. Feltteorien brukes her som grunnlag til å forstå den sosiale entreprenørens mulighet til ressursmobilisering - i form av økonomisk, sosial, kulturell og symbolsk kapital.

Fra felt til verktøy: om Selvhjelp Norge som koordinerende enhet spør hvordan og på hvilke måter Nasjonal plan for selvhjelp og Selvhjelp Norge koordinerer relasjoner og interaksjoner mellom selvhjelpsorganisasjoner og andre sivilsamfunnsaktører som driver selvhjelpsrelatert arbeid. Kapittelet sammenligner to samarbeid mellom frivillige organisasjoner på selvhjelpsfeltet: selvhjelpsseminarene på 1990-tallet og forhandlingene som fant sted før opprettelsen av LINK Trondheim. Analysen viser at nasjonal plan for selvhjelp har påvirket og endret relasjonene mellom aktørene, men til dels på andre måter enn hva som var forutsatt i planen fra 2004. Intervjuer med de involverte i opprettelsen av LINK Trondheim, og med andre organisasjoner som driver selvhjelpsrelatert virksomhet, indikerer imidlertid at det er mindre interaksjon mellom aktørene nå enn for 20 år siden. Zeiner spør om det var en feilaktig diagnose som lå til grunn for Nasjonal plan for selvhjelp. Heller enn et tegn på fragmentering kan det hende at mangfold er et tegn på en fungerende selvhjelpsbevegelse. Dersom dette stemmer, er det problematisk at den nasjonale planen for selvhjelp fremmer en bestemt tilnærming til selvhjelp. Undersøkelsen gir ikke grunnlag for å fastslå om det er Selvhjelp Norge som har vendt seg bort fra organisasjonene, eller om det er organisasjonene som har vendt seg bort fra Selvhjelp Norge. Den kan imidlertid tyde på at Selvhjelp Norge ikke tilbyr ressurser som er sentrale nok for organisasjonene til at de velger å posisjonere seg i kampen om den. I stedet kan det synes som om Selvhjelp Norge i større grad henvender seg til andre aktører, så som velferdstjenester og profesjoner, frivilligsentraler, kommuner og andre offentlige myndigheter. Dette reiser spørsmålet om vi ser konturene av et nytt selvhjelpsfelt, organisert rundt andre aktører, interesser og ressurser.

I avslutningskapittelet Selvhjelp $i$ grenseland - en ny type helsebevegelse? trekker vi trådene sammen. Boken har ved å beskrive den nye 
selvhjelpsbevegelsens fremvekst i forskjellige kontekster fått frem et bilde av en ny type organisasjon og nye arbeidsmåter i grenselandet mellom stat og sivilsamfunn. Vi fokuserer på hvordan de nasjonale selvhjelpsaktørene, Norsk selvhjelpsforum og Selvhjelp Norge, har fremmet selvhjelpssaken innenfor et statlig styringsregime, samtidig som statens politiske målsettinger også har blitt hjulpet frem av de samme selvhjelpsaktørene. Vi beskriver dette som «grensearbeid», som man må forvente bringer frem i lyset iboende spenninger mellom sivilsamfunn og offentlige myndigheter, erfaringskunnskap og profesjonskunnskap, frivillige og fagpersoner. Vi stiller spørsmål om hvor utviklingen går videre. Vi viser til at Norsk selvhjelpsforum og Selvhjelp Norges gjennomslag hos staten er internasjonalt unikt, og i seg selv bemerkelsesverdig. Men det kan også ha hatt en kostnadsside, i form av mindre legitimitet og relevans hos de andre selvhjelpsorganisasjonene.

\section{Referanser}

Aglen, B., Hedlund, M., \& Landstad, B. J. (2011). Self-help and self-help groups for people with long-lasting health problems or mental health difficulties in a nordic context: A review. Scandinavian journal of public health, 39(8), 813-822. https:// doi.org/10.1177/1403494811425603

Austin, J., Stevenson, H., \& Wei-Skillern, J. (2006). Social and commercial entrepreneurship: Same, different, or both? Entrepreneurship Theory and Practice, 30(1), 1-22. https://doi.org/10.1111/j.1540-6520.2006.00107.x

Barth, F. (1972). The role of the entrepreneur in social change in northern norway. Oslo: Universitetsforlaget.

Beck, U., \& Beck-Gernstein, E. (2002). Individualization. Institutional individualism and its social and political consequences. London: Sage.

Borch, O. J., \& Vestrum, I. (2010). Samfunnsentreprenøren og «de gode hjelperne». I O. J. Borch \& A. Førde (Red.), Innovative bygdemiljø: Ildsjeler og nyskapingsarbeid (s. 83-94). Bergen: Fagbokforlaget.

Borkman, T. (1999). Understanding self-help/mutual aid: Experiential learning in the commons. New Brunswick, N.J.: Rutgers University Press.

Bourdieu, P. (1977). Outline of a theory of practice (vol. 16). Cambridge: Cambridge University Press.

Bourdieu, P., \& Wacquant, L. J. (1992). An invitation to reflexive sociology. Chicago: University of Chicago Press.

Brinkmann, S. (2015). Stå imot. Si nei til selvutviklingen. Oslo: Forlaget Press. 
Brottveit, A. (2012). Selvhjelpsarbeid i en lokalsamfunnskontekst: Notat fra en forstudie. Oslo: Diakonhjemmet høgskole.

Callon, M. (1984). Some elements of a sociology of translation: Domestication of the scallops and the fishermen of St Brieuc Bay. The Sociological Review, 32(1_suppl), 196-233. https://doi.org/10.1111/j.1467-954X.1984.tboo113.X

Christensen, T., Lærgreid, P., Roness, P. G., \& Røvik, K. A. (2009). Organisasjonsteori for offentlig sektor: Instrument, kultur, myte (2. Utg.). Oslo: Universitetsforlaget.

Clayton, R., \& Pontusson, J. (1998). Welfare-state retrenchment revisited: Entitlement cuts, public sector restructuring, and inegalitarian trends in advanced capitalist societies. World Politics, 51(1), 67-98. https://doi.org/10.1017/ Soo43887100007796

Dean, M. (2006). Governmentality. Magt \& styring $i$ det moderne samfund. Frederiksberg C: Forlaget Sociologi.

Feiring, M. (2013). Politicisation of Self-Help in Norway. I L. Nicolaou-Smokoviti, Sünker, Heintz, Rozanova, Julia \& Pekka Economou, Victoria (Red.), Citizenship and social development. Citizen participation and community involvement in social welfare and social policy. Frankfurt am Main: Peter Lang Publishing Group.

Fligstein, N. (2001). Social skill and the theory of fields. Sociological Theory, 19(2), 105-125. https://doi.org/10.1111/0735-2751.00132

Fligstein, N., \& McAdam, D. (2012). A theory of fields. Oxford: Oxford University Press.

Foucault, M. (1991). Governmentality. I G. Burchell, C. Gordon \& P. Miller (Red.), The Foucault effect: Studies in governmentality (s. 87-104). Chicago: University of Chicago Press.

Førde, A., \& Borch, O. J. (2010). Innovative bygdemiljø. Ildsjeler og nyskapningsarbeid. Bergen: Fagbokforlaget.

Goffman, E. (1971). The presentation of self in everyday life. Harmondsworth: Penguin Books.

Goodwin, J., Jasper, J. M., \& Polletta, F. (2001). Passionate politics: Emotions and social movements. Chicago: University of Chicago Press.

Harman, G. (2014). Bruno latour: Reassembling the political. London: Pluto Press.

Heaney, C. (2015). Review of Graham Harman's Bruno Latour: Reassembling the political. Theory, Culture \& Society.

Hedlund, M., \& Landstad, B. (2012). The construction of self-help in Norwegian health policy. International Journal of Self Help and Self Care, 6(1), 65-87.

Helsedepartementet. (2003). Resept for et sunnere Norge: Folkehelsepolitikken (St. Meld. Nr. 16 (2002-2003)). Oslo: Helse- og omsorgsdepartementet.

Helse- og omsorgsdepartementet. (2013). Morgendagens omsorg (St. Meld. Nr. 29 (2012-2013)). Oslo: Helse- og omsorgsdepartementet.

Helsedirektoratet. (2014). Nasjonal plan for selvhjelp 2014-2018. Oslo: Helsedirektoratet. 
Hjemdal, O. K. (1995). Oversikt over det mangfold av selvhjelpsvirksomhet som finnes i Norge. I S. Nilsen \& S. Talseth (Red.), Selvhjelp på norsk: Rapport fra selvhjelpsseminaret 12.-13. Februar 1995. Oslo: NotaBene, Ø.K.S-rapport nr. 95:6.

Hjemdal, O. K. (1996). Status for selvhjelpsfeltet. I O. Sandvik (Red.), Selvhjelp på norsk. Rapport fra selvhjelpsseminaret26.-28. April 1996. Oslo: Høgskolen i Oslo, Avdeling for økonomi-, kommunal- og sosialfag.

Humphreys, K., Wing, S., McCarty, D., Chappel, J., Gallant, L., Haberle, B., Horvath, T., Kaskutas, L. A., Kirk, T., Kivlahan, D. Laudet, A., McCrady, B. S., McLellan, T., Morgenstern, J., Townsend, M. \& Weiss, R (2004). Self-help organizations for alcohol and drug problems: Toward evidence-based practice and policy. Journal of Substance Abuse Treatment, 26(3), 151-158. https://doi.org/10.1016/So740-5472(03)oo212-5

Høgsbro, K. (1992). Sociale problemer og selvorganiseret selvhjoelp i Danmark. Fredriksberg: Samfundslitteratur.

Illouz, E. (2008). Saving the modern soul. Therapy, emotions, and the culture of selfhelp. Berkeley: University of California Press.

Ingstad, E. S. L. (2009). Sosialt entreprenørskap - en klargjøring av begrepet. I B. Schei \& E. Rønnevig (Red.), Vilje til endring: Sosialt entreprenørskap på norsk. Notodden: Mother Courage.

Jenkins, R. (1992). Pierre Bourdieu. London: Routledge.

Karlsson, M. (2006). Självhjälpsgrupper: Teori och praktik. Lund: Studentlitteratur.

Katz, A. H. (1993). Self-help in America: A social movement perspective. New York: Twayne Publishers.

Katz, A. H., \& Bender, E. I. (1976). Self-help groups in Western society: History and prospects. The Journal of Applied Behavioral Science, 12(3), 265-282.

Kroken, R., \& Madsen, O. J. (Red.). (2016). Forvaltning av makt og moral i velferdsstaten. Fra sosialt arbeid til «arbeid med deg selv»? Oslo: Gyldendal Akademisk.

Kuhnle, S., \& Solheim, L. (1991). Velferdsstaten-vekst og omstilling. Oslo: Tano.

Lasch, C. (1991). The culture of narcissism: American life in an age of diminishing expectations. New York: Norton.

Latour, B. (2007). Turning around politics: A note on Gerard de Vries' paper. Social Studies of Science, 37(5), 811-820.

Latour, B. (2008). Pour un dialogue entre science politique et science studies. [For a dialogue between political science and science studies]. Revue française de science politique, 58(4), 657-678. https://doi.org/10.3917/rfsp.584.0657

Lundgaard Andersen, L., \& Hulgård, L. (2014). Socialt entreprenørskab og social innovation. I N. ministerråd (Red.), Sosialt entreprenørskap og sosial innovasjon. Kartlegging av innsatser for sosialt entreprenørskap og sosial innovasjon i norden. København: Nordisk ministerråd.

Lundgren, G. V. (2010). Självhjälpens retorik: En Foucaultinspirerad textanalys av norsk selvhjelpsformums introduktionshäfte sevlhjelp: En innføring. Master i helsefag, Universitetet i Oslo, Oslo. 
Madsen, O. J. (2010). Den terapeutiske kultur. Oslo: Universitetsforlaget.

Madsen, O. J. (2014). Det er innover vi må gå. En kulturpsykologisk studie av selvhjelp. Oslo: Universitetsforlaget.

Matzat, J. (1992). Selvhjelpsgrupper som grunnleggende behandlingsform i psykoterapi og sosialt arbeid. I L. Fyrand (Red.), Perspektiver på sosialt nettverk (s. 180-186). Oslo: Universitetsforlaget.

Matzat, J. (2002). The development of self-help groups and support for them in Germany. International Journal of Self Help and Self Care, 1(4), 307-322.

Munn-Giddings, C., \& Borkman, T. (2005). Self-help/mutual aid as a psychosocial phenomenon. I S. Ramon \& J. Williams (Red.), Mental health at the crossroads. The promise of the psychosocial approach. Aldershot: Ashgate Publishing.

Norske kvinners sanitetsforening. (1971). Norske kvinners sanitetsforening 1946-1971: B. 2: Arbeidsperioden 1946-1971 (Vol. B. 2). Oslo: Foreningen.

NSF. (200o). Årsmelding 1999 Hentet fra http://norskselvhjelpsforum.no/filestore/ NSF_rsmelding_1999.pdf

NSF. (2002). Årsrapport 2001 Hentet fra http://norskselvhjelpsforum.no/filestore/ NSF_rsmelding_2001.pdf

NSF. (2003). Årsmelding 2002 Hentet fra http://norskselvhjelpsforum.no/filestore/ NSF_rsmelding_2002.pdf

Oka, T., \& Borkman, T. (200o). The history, concepts and theories of self-help groups: From an international perspective. Japanese Journal of Occupational Therapy, 37, 718-722.

Pistrang, N., Barker, C., \& Humphreys, K. (2008). Mutual help groups for mental health problems: A review of effectiveness studies. American Journal of Community Psychology, 42(1), 110-121. https://doi.org/10.1007/s10464-0089181-O

Rose, N., \& Miller, P. (1992). Political power beyond the state: Problematics of government. British Journal of Sociology, 43(2), 173-205.

Salem, D. A. (1996). Book review: Self-help in America: A social movements perspective, a. H. Katz, NY, Twayne Publishers, 1993, 128 pp. Health, Education \& Behaviour, 23(1), 116-199.

Seligman, M. E. P. (2006). Learned optimism: How to change your mind and your life. New York: Vintage.

Selle, P., Strømsnes, K., \& Loga, J. (2018). State and civil society: A regime change? I B. Enjolras \& K. Strømsnes (Red.), Scandinavian civil society and social transformations: The case of Norway (s. 117-163). Cham: Springer International Publishing.

Selvhjelp Norge (2012). Rapport for selvhjelp norges virksomhet. 2011: Selvhjelp Norge.

Sosial- og helsedirektoratet. (2004). Nasjonal plan for selvhjelp. Oslo: Sosial- og helsedirektoratet. 
Star, S. L., \& Griesemer, J. R. (1989). Institutional ecology, 'translations' and boundary objects: Amateurs and professionals in Berkeley's Museum of Vertebrate Zoology, 1907-39. Social Studies of Science, 19(3), 387-420. https://doi. org/10.1177/030631289019003001

Stefansen, K. (2006). Krisesentrene i Norge - fra sosial bevegelse til profesjonaliserte hjelpetiltak. Nordisk sosialt arbeid, 26(01), 27-37.

Stokken, R. (2015). Janusian liminality: A key to the accountability of the equality between users and professionals in patient education in Norway. Trondheim: NTNU.

Stokken, R., Barstad, J., \& Thokle, G. (2012). Impeding or promoting a grassroots phenomenon?-on self-help projects as public sector means in Norway. International Journal of Self Help and Self Care, 6(1), 89.

Trägårdh, L. (1997). Statist individualism. I Ø. Sørensen \& B. Stråth (Red.), The cultural construction of Norden. Oslo: Scandinavian University Press.

Trägårdh, L., Selle, P., Henriksen, L. S., \& Hallin, H. (2013). Civilsamhället klämt mellan stat och kapital: Välfärd, mångfald, framtid.

Vederhus, J.-K. (2009). Selvhjelpsgrupper i rusfeltet - en kunnskapsoppdatering. Oslo: Helsedirektoratet.

Vederhus, J.-K. (2011). Addiction professionals' and substance abuse patients' attitudes towards and usage of 12-step-based self-help groups. Oslo: Seraf.

Vederhus, J.-K., \& Kristensen, Ø. (2006). High effectiveness of self-help programs after drug addiction therapy. BMC Psychiatry, 6(1), 35. https://doi. org/10.1186/1471-244X-6-35

Vike, H. (2004). Velferd uten grenser: Den norske velferdsstaten ved veiskillet. Oslo: Akribe.

Zeiner, H. H. (2014). Konsolidering på et fragmentert felt. NIBR-notat 2014(105), 1-44. 


\title{
Selvhjelpsgrupper og behandlingsgruppers tilnærming til personlig endring - hva er likt og ulikt?
}

\author{
Ånund Brottveit \\ KIFO, Institutt for kirke-, religions- og livssynsforskning
}

\begin{abstract}
In this chapter, the author discusses how, and to which extent, self-help groups differ from treatment groups in their approach to personal transformation. The focus is on the self-help group's work, exploring what kind of community a selfhelp group is and what is happening there. The chapter compares two main models for self-organized self-help groups and points out some common "therapeutic mechanisms" that are also shared by therapy groups. At the same time there are interesting differences, not only between professional group therapy and self-help groups, but also between a 12-step group (e.g. Anonymous Alcoholics) and a typical "Self-help Norway group". Self-help Norway is more psychologically oriented and emphasizes personal autonomy and self-control, while AA groups build up under a strong collective identity and view self-control as an illusory target for an addict. The author argues that the primary objective of self-help groups is not making new intimate friends. The therapeutic effectiveness of self-help groups seems to depend on that the intimacy and confidentiality within the group does not transform it into a "new family". It is the quality of becoming "confidential strangers" that is the clue here.
\end{abstract}

Keywords: confidential strangers, self-help models, mutuality, therapeutic culture, social technology

\section{Innledning}

Du skal vise et ansikt utad, du skal være sterk! På møtet har jeg fått legge «gørra» på bordet. Som mor skal du skåne, ikke belaste, resten av familien. Jeg sa hele

Sitering av dette kapittelet: Brottveit, $\AA$. (2019). Selvhjelpsgrupper og behandlingsgruppers tilnærming til personlig endring - hva er likt og ulikt? I Å. Brottveit \& M. Feiring (Red.), Samarbeid om selvhjelp. En antologi om den nye selvhjelpsbevegelsen $i$ Norge (s. 47-68). Oslo: Cappelen Damm Akademisk. https://doi.org/10.23865/ noasp.68.ch2

Lisens: CC BY 4.0 
tida «det går kjempefint!» for å roe ned situasjonen. Jeg løy til mor, min sønn og folk jeg møtte. Jeg holdt på sånn i 5 år! (Gruppedeltaker)

I dette kapittelet vil jeg se nærmere på hvordan deltakerne opplever selvhjelpsgruppene, hva som skjer der, og hvorfor noen velger dette fremfor å bare bruke familie og venner. Et spørsmål som det er naturlig å stille, er om selvhjelpsgruppa er en slags erstatning for et sosialt nettverk? Lokalsamfunn vil ofte være preget av sterke sosiale nettverk og mye foreningsvirksomhet, behøver de likevel slike samtalegrupper i tillegg? Et annet spørsmål handler om forskjellen på selvhjelpsgrupper og behandlingsgrupper. Behandlingsgrupper og selvhjelpsgrupper har begge en målsetting om å skape personlige endringsprosesser. Er selvhjelpsgrupper også en form for terapi - en "psykoterapi uten psykoterapeuter» (Matzat, 2002)? Avslutningsvis vil jeg drøfte de terapeutiske aspektene som et mulig tegn på at vi har å gjøre med en sosial teknologi (Dean, 2006) og et symptom på bredere, samfunnsmessige utviklingstrekk. Er den terapeutiske dreiningen i selvhjelpsgruppene et uttrykk for en samfunnsutvikling der enkeltmennesket er mer sårbart? Speiler den nye typen selvhjelpsgrupper et samfunn som i økende grad krever at man arbeider med seg selv?

Informantene i deltakerstudien, som ligger til grunn for analysen, har vært deltakere i selvhjelpsgrupper som ble etablert i en rural kommune i Nord-Troms, en by i Finnmark og et tettsted i Vest-Oppland. De fleste av de intervjuede har vært med i selvhjelpsgrupper hvor man regelmessig møtes ansikt til ansikt på et fast sted, mens noen har deltatt i telefonbaserte grupper. Informantene kommer fra ulike selvhjelpsgrupper og bosteder i Norge, det betyr at de også representerer forskjellige kulturelle kontekster. Det er også interessant at intervjuutvalget har deltakere fra selvhjelpsgrupper som var både tilsluttet Anonyme Alkoholikere og Selvhjelp Norge. I forskningslitteraturen omtales ulike typer selvhjelpsgrupper ofte under ett, som om de har samme ideologi og arbeidsform, noe jeg mener er problematisk.

Selvhjelp Norge og Anonyme Alkoholikere (AA) representerer to sentrale, men også distinkt forskjellige, selvhjelpsgruppetradisjoner. Det er viktige forskjeller i den bakenforliggende ideologien og arbeidsformen. Felles er målsettingen om en individuell psykososial endring hos deltakeren, og at dette oppnås gjennom en gruppeprosess som i hovedsak 
benytter samtaler. En slik målsetting og arbeidsform kan minne om ulike behandlingsformer som er basert på gruppesamtaler. I Selvhjelp Norge og AA betraktes imidlertid gruppenes autonomi vis-a-vis behandlingsapparatet og det at de er basert på erfaringsbasert kunnskap som grunnleggende prinsipper.

Jeg vil i dette kapittelet sammenligne 1) Selvhjelp Norges og AAs modeller for selvorganiserte selvhjelpsgrupper, dernest 2) sammenligne disse med gruppebaserte behandlingsformer.

De aktuelle behandlingsgruppene jeg vil vise til, representerer en form for gruppepsykoterapi som vektlegger dynamikken og utvekslingene mellom gruppedeltakerne. Jeg tar utgangspunkt i den formen for psykodynamisk og relasjonsorientert gruppeterapi som beskrives i den amerikanske psykiateren Yaloms bøker (Arntson \& Droge, 1987; Karterud, 1999; Yalom \& Leszcz, 2005).

Hensikten med disse komparasjonene er å sette søkelys på hvilke terapeutiske mekanismer det er som antas å være virksomme i de ulike gruppetypene. Et svært viktig tema vil være betydningen av åpen kommunikasjon mellom deltakerne og om det betyr noe at en behandler er til stede eller ikke.

Selvhjelpsgrupper har to prinsipper som anses som helt sentrale: anonymitetsprinsippet, som betraktes som en forutsetning for åpenhet og fortrolighet, og gjensidighetsprinsippet, som definerer relasjonene mellom gruppas deltakere som «likestilte». Jeg vil undersøke om ikke nettopp noe av gruppas virkningskraft ligger her, og jeg vil drøfte hvordan behandlingsgrupper kanskje gjør bruk av de samme mekanismene.

\section{Metode}

Det empiriske materialet for dette kapittelet er en undersøkelse av selvorganisert selvhjelp i lokalsamfunn, hvor det inngår en intervjuundersøkelse blant gruppedeltakere ( $15 \mathrm{i}$ alt). Jeg har gjort tre case-studier av lokalsamfunn hvor det har vært en etablering og videreutvikling av selvhjelpsgruppeaktivitet. I tillegg til å intervjue lokale deltakere har jeg også intervjuet deltakere i telefongrupper i Nord-Norge. Datainnsamlingen ble foretatt i perioden 2010-2012. 
Case-stedene i henholdsvis Troms, Finnmark og Vest-Oppland representerer forskjellig grad av urbanitet, ulik lokal kultur og forskjeller når gjelder rammen selvhjelpsgruppene er organisert innenfor. I dette kapittelet kontrasterer jeg imidlertid ikke ulike caser, men legger vekt på de sterke, felles betingelsene som mindre lokalsamfunn gir for selvhjelpsgruppenes virkemåte (se kapittel 6 for en bredere diskusjon av ett av casene når det gjelder å forankre selvhjelpsarbeid i et lokalsamfunn). ${ }^{1}$

\section{Oversikt datamateriale}

\begin{tabular}{|c|c|c|c|c|}
\hline Intervjuer: & SN-gruppe & AA-gruppe & hybrid* & Sum \\
\hline \multirow[t]{2}{*}{ Deltakere } & 7 & 6 & 2 & 15 \\
\hline & \multicolumn{2}{|l|}{ Lokal gruppe } & Telefongruppe & Sum \\
\hline Deltakere & \multicolumn{2}{|l|}{11} & 4 & 15 \\
\hline
\end{tabular}

*blandet elementer fra 12-trinnsgrupper med SN-modellen

To intervjupersoner var i ei gruppe som kombinerte de to selvhjelpsmodellene ved at de brukte «trinnene» i AA-modellen som tema for gruppesamtalene. Fire informanter tilhørte ei telefonbasert gruppe (Selvhjelp Norge).

Tema for intervjuene var de individuelle erfaringene med å gå i gruppe, refleksjoner rundt behovet for ei selvhjelpsgruppe når man bor i et lokalsamfunn, paralleller og kontraster til behandlingstilbud, sammenligninger mellom hvordan man snakker i ei selvhjelpsgruppe og i andre kontekster, og opplevd nytte.

Utvelgelsen av intervjupersoner skjedde i samarbeid med den lokale personen som koordinerte selvhjelpsgruppene. Kriteriet var at de hadde erfaring fra mer enn ett møte, og at de var villige til å bli intervjuet. Det ble lagt vekt på å få en best mulig kjønnsbalanse, slik at erfaringer og synspunkter fra både kvinner og menn ble representert. Aldersmessig er informantene fra midten av 20-årene til midten av 60-årene. Utvalget kan

1 Norsk selvhjelpsforum/Selvhjelp Norge var sterkt inne i bildet i Nord-Troms og i opprettelsen av den telefonbaserte gruppen. I Finnmark var AA godt etablert fra før, mens en annen aktør i sivilsamfunnet, Finnmarksnettverket, inviterte ulike aktører til et samarbeid om selvhjelpsgrupper. Finnmarksnettverket inviterte også inn Selvhjelp Norge i dette samarbeidet. I Vest-Oppland var alle selvhjelpsgruppene i regi av AA i datainnsamlingsperioden, selv om AA lokalt også hadde møter med Selvhjelp Norge. 
samlet sett betraktes som et strategisk utvalg som fanger opp de viktigste av de på forhånd kjente variasjonene i gruppetyper og problemtyper hos deltakere på case-stedene.

\section{Anonymitet og gjensidighet - en sammenligning av selvhjelpsmodellene}

Anonymitetsprinsippet praktiseres av alle selvorganiserte selvhjelpsgrupper i Norge. Anonyme Alkoholikere fremfører to hovedbegrunnelser for dette prinsippet: 1) Det senker terskelen for å søke hjelp hos nye deltakere som ofte er plaget av skam og skyldfølelse. 2) Det motvirker faren for at enkeltpersoner utnytter sin tilhørighet og erfaring fra bevegelsen til å vinne status i samfunnet, noe som kunne vikle AAs navn og rykte inn i politiske diskusjoner og saker (Anonyme Alkoholikere, 2006; Bateson, 1972, s. 333-334; Borkman, 1999). Felles for grupper med tilknytning til AA-bevegelsen, de såkalte 12-trinnsgruppene, er at de ønsker å arbeide i det stille og forbli fullstendig nøytrale og autonome i forhold til myndigheter, næringsliv og andre sosiale institusjoner og bevegelser i samfunnet.

Selvhjelp Norge deler AAs første begrunnelse for anonymitet. Anonymitet anses som en forutsetning for at mange vil våge å delta i ei gruppe og snakke åpent om sine problemer der. Det er imidlertid ingen regel som «forbyr» den enkelte deltakeren å si offentlig at vedkommende selv deltar i ei selvhjelpsgruppe eller bruke seg selv som eksempel for å spre informasjon om selvhjelpsarbeid. Det er ikke en fast «mal» for hvordan grupper sammensettes og fungerer, men Selvhjelp Norges representanter anbefaler at deltakerne ikke har nære relasjoner til hverandre fra før, eller at de lar gruppa danne utgangspunkt for sosiale aktiviteter sammen. De gir uttrykk for at deres anbefalinger bygger på akkumulerte erfaringer fra et mangfold av selvhjelpsgruppers virksomhet over flere tiår. Det fremholdes at hovedaktiviteten i selvhjelpsgruppa er samtaler med utgangspunkt i deltakernes personlige problemer, men det advares mot å «gi råd», med mindre noen direkte ber om det.

Selvhjelp Norge-gruppas (SN) prinsipp om at hver og en snakker ut ifra seg selv og fortrinnsvis holder oppmerksomheten på livet «herog-nå», fremfor å «grave i fortida» etter årsaker, er en tydelig rettesnor. 
Det klare skillet mellom dagliglivets relasjoner og aktiviteter og selvhjelpsgruppas adskilte sosiale rom, har en virkning i flere retninger: Det sosiale nettverket kjenner ikke deltakerens sosiale aktivitet innenfor en konkret selvhjelpsgruppe, og selvhjelpsgruppa relaterer seg heller ikke direkte til deltakerens sosiale nettverk og ulike posisjoner i samfunnet utenfor. Gruppedeltakernes sosiale identiteter utenom gruppa blir derfor mindre relevante og nedtonet når det gjelder hvordan de presenterer seg selv i gruppesamtalene. På denne måten kan man si at deltakerne også opprettholder en viss anonymitet vis-à-vis hverandre.

SN-gruppas deltakere bevarer altså en viss anonymitet i gruppa, til tross for at de vanligvis deler svært fortrolig og personlig informasjon. Det samme gjelder for AA, som endog har eksplisitte konvensjoner for tiltale ved bruk av kun fornavn, faste fraser for hilsener og takking for hverandres meddelelser osv. I selvhjelpsgruppa er deltakerne til en viss grad «depersonalisert», de oppfordres til å legge bort den sosiale statusen de måtte ha i sin jobb, eller den offisielle «fasaden» de har i lokalsamfunnet (Valverde, 1998). Identiteten som «alkoholiker»/«avhengig» fremheves i selvpresentasjonene: «Jeg heter Per og jeg er alkoholiker.»

Gjensidighetsprinsippet bygger på at deltakerne har likestilte roller $\mathrm{i}$ gruppa og at kunnskapen er erfaringsbasert - alle har i prinsippet lik rett til å påberope seg denne kompetansen. Det er altså ikke noe sosialt hierarki eller kunnskapshierarki i gruppa - i utgangspunktet. Hva som utspiller seg i praksis, kan selvsagt være mer variert og vil ikke alltid følge idealet. Hovedtanken bak gjensidighetsprinsippet er likevel at alle deltakerne er der for å «hjelpe seg selv», med et eget problem. Det er ikke noen som har en ren «hjelperrolle» overfor andre. Ingen skal være «eksperter», slik at de andre blir «lekfolk» (Andresen \& Talseth, 2000; Borkman, 1999; Matzat, 1992a, b).

AA-gruppene kombinerer en hierarkisk modell med en egalitær. De opererer med en «stige» $\mathrm{i}$ form av 12-trinnsprogrammet, og begreper som «sponsor», «fadderordninger» og «veteraner» antyder asymmetriske relasjoner. Samtidig understreker de at det alltid dreier seg om «en alkoholiker som hjelper en annen». AA-gruppa velger en person (en deltaker) til å lede møtet, noe som innebærer å lese bestemte tekster, lede gruppa gjennom de ulike sekvensene i møtet og sette i gang samtalene («delingen»). Selvhjelp Norge vektlegger likhetsprinsippet sterkere - alle 
gruppedeltakerne forutsettes å ha samme status. SN-gruppa er i prinsippet «lederløs». Hvis det er en igangsetter med i starten, vil denne personen få en naturlig lederrolle så lenge vedkommende deltar. Senere vil det kunne oppstå uformelle ledere, intervjuene tyder på det. Men gruppene anbefales å være på vakt mot dette og begrense slike rollefordelinger før de festner seg.

Selvhjelp Norge anbefaler «lukkede» grupper, mens Anonyme Alkoholikere og andre 12-trinnsgrupper vanligvis tar inn nye medlemmer fortløpende. Ei AA-gruppe vil lettere få en blanding av nykommere og mer rutinerte gruppedeltakere enn ei gruppe som har fulgt Selvhjelp Norges rammer, men dette er også en mulighet for sistnevnte. Mange gruppedeltakere deltar i ei ny gruppe når den gamle blir oppløst. Selvhjelp Norge anbefaler at eksisterende grupper rekonstituerer seg som «ny» gruppe når et nytt medlem tas inn.

I AA-gruppene er det et høyst legitimt og sågar «feiret» hierarki blant deltakerne når det gjelder varigheten på deres «edruskap/nykterhet»og avansement på 12-trinnsskalaen. Dette markeres ved hjelp av seremonielle årsmarkeringer og utdelinger av medaljer. «Veteranene» får også ofte forespørsler om å opptre som «sponsorer», det vil si en slags individuelle veiledere og støttespillere for nykommere utenfor møtekonteksten. Det er ingen slike offisielle former for anerkjennelse av «veteraner» i ei $\mathrm{SN}$-gruppe. En sponsor i AA-gruppa har åpenbart en spesiell rolle visà-vis den relaterte nykommeren som moralsk støtte og åndelig veileder. Vi kan stille spørsmålet om dette også indikerer en forskjell i kunnskap, siden veteranene kan betraktes som bærere av gruppas akkumulerte kunnskap og som sådan mer kunnskapsrike enn de ferske medlemmene. For SN-gruppas del kan vi stille spørsmålet om ikke lignende rolleinndelinger og kunnskapshierarkier lett vil danne seg også her, men mer implisitt.

Borkman (1999) ser det som sentralt for selvorganiserte selvhjelpsgrupper at de kan utvikle en sterk fellesskapsfølelse og en ny og forløsende måte å betrakte medlemmenes problemer på («liberating meaning perspective»). Hun vektlegger både gruppas akkumulering av erfaringskunnskap som gradvis blir en slags gruppe-ideologi eller gruppe-kultur, og gruppas synsvinkel eller tolkningsramme som åpner for en ny 
forståelse av problemene. Den kollektive prosessen antas å løpe sammen med den enkeltes individuelle prosess.

Deltakelse i selvorganiserte selvhjelpsgrupper har som målsetting å skape en forandring i egen situasjon ved hjelp av egen innsats - en selv-transformasjon. Psykoterapeutisk behandling har ofte en lignende måte å beskrive prosessen på. I gruppebaserte psykoterapier legges det også opp til gjensidig «deling» mellom klientene og gruppedynamiske prosesser som kan utnyttes terapeutisk (Yalom \& Leszcz, 2005). Det er likevel en vesentlig forskjell sammenlignet med selvorganisert selvhjelp i og med behandlerens tilstedeværelse, lederrolle og fortolkningsmakt. Behandlerens rolle i gruppeterapien begrunnes til dels med at man da kan gå lenger når det gjelder å håndtere sterke emosjonelle reaksjoner i gruppa og få mer ut av tolknings- og refleksjonsarbeidet. Vi kan gjenkjenne denne forståelsen i AA-bevegelsens praktisering av "parallell historiefortelling» i selvhjelpsgruppekonteksten, og Minnesotamodellens bruk av «speiling» og konfrontasjoner i behandlingskonteksten (Cook, 2006) (Minnesotamodellen er basert på AA-tradisjonen). Speiling innebærer at en terapeut, eller andre gruppedeltakere, gir direkte reaksjoner på andres væremåte, ofte uten å ta spesielle hensyn til høflighetsregler eller den andres følelser som man i normale situasjoner ville gjort. Det er fordi man tror det gir anledning til større selvinnsikt og fordi gruppa eller terapeuten gir tilstrekkelig trygghet.

Erfaringsbasert kunnskap og deling av historier vektlegges også i terapeutiske samtalegrupper, og det er et selvsagt premiss at slike utleveringer skjer under konfidensialitet. Visse trekk ved terapeutiske samtalegrupper skiller dem klart ifra selvorganiserte selvhjelpsgrupper, spesielt den profesjonelle møtelederrollen og bruken av fagkunnskap (erfaringskunnskap versus fagkunnskap drøftes i kapittel 4). Likevel spør jeg om disse forskjellene er vesensforskjeller eller gradsforskjeller når det gjelder gruppenes funksjonsmåte og virkningsmekanismer?

\section{Terapeutiske mekanismer i gruppepsykoterapi}

Som nevnt betraktes anonymitet i form av konfidensialitet som vesentlig for å skape åpenhet og tillit i selvhjelpsgrupper (Valverde, 1998). Det samme kan sies om behandler-pasient-relasjonen. Informasjon, gitt til en 
lege eller psykolog, er fortrolige opplysninger som man vanligvis stoler på at blir voktet som en hemmelighet. Lovgivning og yrkesetiske retningslinjer gir helsepersonell klare og strenge grenser for informasjonsutveksling.

Selvhjelpsgruppenes gjensidighetsprinsipp står imidlertid i kontrast til den klare asymmetrien som er mellom en profesjonell behandler og en pasient, f. eks. i en psykoterapeutisk behandlingskontekst. Selv om relasjonen i sistnevnte er mer asymmetrisk, stilles det krav til relasjonell kvalitet som kan minne om dem man finner i selvhjelpsgruppa: Psykoterapi tar også utgangspunkt i det pasienten eller klienten bringer inn i form av verbale bidrag: Arbeidsformen er samtaler der relasjonen som utvikles, også kalt arbeids- eller behandlingsalliansen, anses som helt sentral for et positivt resultat (Duncan, Miller \& Sparks, 2004; Wampold, 2001). Likheten blir større når vi ser på gruppebasert psykoterapi, en mellomform som drar veksler både på terapeutens profesjonelle bidrag og gruppas egen dynamikk.

Psykiateren Yalom har selv utviklet psykoterapi i grupper og beskrevet dette i bøker med betydelig innflytelse i norsk psykiatri (Karterud, 1999; Yalom \& Leszcz, 2005). Den fortrolige selvutleveringen er sentral her, som i all samtaleterapi, men drives også frem ved hjelp av gruppedynamikken. De andre klientenes spontane reaksjoner og assosiasjoner stimulerer et kollektivt refleksjonsarbeid, ikke ulikt det man kan oppleve i ei selvhjelpsgruppe. Her blir det imidlertid også hjulpet frem av behandlerens kommentarer og spørsmål. Yalom vil dessuten hevde at behandlerens tilstedeværelse gjør det forsvarlig å drive denne «speilingen» og «boringen» lenger enn i ei selvhjelpsgruppe. Dette er for øvrig et synspunkt som AA-bevegelsen deler, da de vil henvise dette til kliniske settinger. Yalom oppfatter behandlingsgruppa som et eget «sosialt mikrokosmos», hvor klientenes typiske reaksjonsmønstre og relasjoner gjenskapes - og derfor blir tilgjengelig for terapeutisk behandling.

Når Yalom selv regner opp det han anser som de viktigste terapeutiske faktorene, så er det et påfallende sammenfall med hva selvhjelpstalspersoner fremhever ved selvhjelpsgruppene. Yalom viser selv til erfaringer med selvhjelpsgrupper for å underbygge og illustrere de samme virkningsmekanismene. Jeg lister opp flere terapeutiske faktorer som jeg har hentet fra Yalom: 


\section{Yalom (2005): Terapeutiske faktorer (min oversettelse)}

Håp

Altruisme

Informasjonsdeling

Alminneliggjøring

En korrigert gjenskapelse av den primære familiegruppen

Utvikling av sosiale ferdigheter

Imitere adferd

Alle mekanismene som Yalom nevner her, er gjenkjennbare fra selvhjelpsgruppene, men ikke alltid like eksplisitt. Å inngi håp er kanskje tydeligst i AA-gruppenes dyrking av en bestemt fortellings-sjanger, den om alkoholikeren som «faller» for så å «reise seg igjen». Håp signaliseres også gjennom rollen veteranene har i AA-fellesskapet som eksempler på tilfriskning. Altruismen blir knyttet til en form for egeninteresse ved at en «tørrlagt alkoholiker» alltid vil være en alkoholiker. Den beste måten å sikre sitt eget edruskap på er å hjelpe og støtte andre, det såkalte «hjelper-terapi prinsippet» (Riessman, 1976). Veteranene er også forbilder som nykommerne kan ta etter når det gjelder måter å snakke på og forholde seg til hverandre på. Informasjonsdeling om diagnoser, behandlingsmetoder osv. er vanligere i diagnosebaserte selvhjelpsgrupper, f. eks. grupper for kvinner med brystkreft. Alminneliggjøring er et resultat av at man deler erfaringer og vonde følelser med hverandre i gruppa - behandlingsgruppa eller selvhjelpsgruppa. På denne måten kan deltakerne oppdage hvor universelle erfaringene egentlig er - at man er «i samme båt».

Yalom legger vekt på at behandlingsgruppa både vil fungere som en relativt fortrolig primorgruppe og inneholde ulike personligheter, av og til slik at de kan minne om ens egen familie. Dette vil ofte utløse reaksjoner som i psykoterapeutisk terminologi kalles «overføring». Overføringsmekanismene som er kjent fra psykoanalytisk behandling multipliseres når den tradisjonelle terapeutiske dyaden blir utvidet til en terapigruppe. Innlærte reaksjonsmønstre og relasjonstyper fra familiesamspillet gjenskapes og kan dermed kommenteres og korrigeres i den nye settingen.

I behandlingsgruppa vil man kunne loere bedre sosiale ferdigheter både gjennom å observere andre og ved å få direkte tilbakemeldinger på seg selv. En slik åpen og direkte samtale om hvordan vi er og virker på 
hverandre, samtidig som deltakerne skal ivaretas, er vanskelig å oppnå i naturlige samspillsettinger.

Kontakt og samvær utenom gruppesettingen kan true gruppemøtenes terapeutiske funksjon, i hvert fall dersom det ikke er full åpenhet om denne kontakten. Yalom beskriver mange eksempler på hvordan dette kan undergrave gruppefellesskapet og muligheten for å arbeide terapeutisk med relasjonene mellom deltakerne. Når ei gruppe etableres, vil man unngå å rekruttere deltakere som er i familie eller tilhører samme sosiale nettverk. Men Yalom avviser ikke totalt at kontakt utenom møtene kan være positivt - og det er trolig også hans erfaring at det ville være urealistisk å fullstendig unngå dette. Betingelsen er at reglene som gjelder for samvær i behandlingsgruppa, også gjelder under samvær utenom, og at slike møter er helt transparente for resten av gruppa. Behandlingsgruppa er et sted hvor man kan utvikle seg selv og sine evner til å håndtere sosiale relasjoner, den er ikke ment å være det stedet hvor man finner nye venner og får dekket sine sosiale behov. Yalom sier at gruppa er en «bro», ikke en «endestasjon» (Yalom \& Leszcz, 2005).

\section{Empiriske funn}

\section{Intern konfidensialitet: Fortrolige fremmede}

De andre, psykologen, venner, familiemedlemmer etc. - de har jeg et forhold til fra før. Kontakten med dem blir ofte ganske styrt med tankene mine. Følelsene inni meg blir sperret av tankene mine fordi jeg har et forhold til dem fra før. (Gruppedeltaker/SN-gruppe)

Hvorfor kan man ikke bruke sine nærmeste kontakter i det sosiale nettverket i stedet for ei behandlingsgruppe eller selvhjelpsgruppe? I mange tilfeller kan man selvsagt det. Det vil kunne avhenge av arten og graden av de problemene man sliter med, og det kan avhenge av hva slags venneog familierelasjoner man har. Det synes likevel å være en grunnleggende forskjell mellom gode fortrolige relasjoner i det sosiale nettverket og det som jeg her kaller «fortrolige fremmede» - andre deltakere i ei fungerende selvhjelps- eller behandlingsgruppe.

Informantene fra selvhjelpgruppene sa at det var lettere å snakke om visse ting i selvhjelpsgruppa, enn med gode venner eller nær familie. De 
la vekt på at de nære relasjonene i det sosiale nettverket kunne komplisert en slik åpenhet, og gjort dem mer tilbakeholdne og ufrie.

Man kan ha en samboer i huset som man kan betro seg til, men en dag blir man kanskje uvenner, og så blir alt brukt mot deg. I selvhjelpsgruppa har vi ikke nære relasjoner til hverandre, og derfor kan ikke dette skje der. (Gruppedeltaker/ SN-gruppe)

En viktig følge av å dele svært personlige ting med andre er at man gjør seg sårbar:

Det er at man viser at man er sårbar, er blitt såret, har sorg, er lei seg, skammer seg. Viser alt som er bak det som du viser når du går på butikken og later som at alt er i orden. (Gruppedeltaker/SN-gruppe)

Blottstillelsen som følger av slike personlige utleveringer krever stor grad av tillit til de andre i gruppa. Samtidig kan selvutleveringen sees som en handling som i seg selv skaper grunnlaget for denne tilliten. Når én deltaker først har åpnet seg, er det lettere for andre å gjøre det samme.

Delingssirkelen ('the sharing circle') er en teknikk som praktisk talt alle samtalebaserte selvhjelpsgrupper og også terapigrupper med behandlere benytter. Sirkelen signaliserer både likestilthet og fellesskap - ingen sitter «nederst ved bordet», og alle forventes å bidra. Å snakke åpent om personlige eller familiære problemer krever ofte en overvinnelse, og det kan være vanskeligere på mindre steder der de andre gruppedeltakerne tilhører det samme lokalsamfunnet.

At jeg skulle fortelle til «bygdas folk» liksom!?! Men så tenkte jeg ... «skitt au!» (Gruppedeltaker/SN-gruppe)

Forventningen om å være åpen og fortelle om sitt problem kan være litt tvetydig kommunisert, ved at nye potensielle gruppedeltakere, enten det er i en AA-gruppe eller SN-gruppe, gjerne blir beroliget med at de ikke skal føle seg presset, at de ikke behøver å si mer enn de har lyst til osv.

Det var ei som jeg bet meg merke i. Jeg sa til henne i en samtale at hun «aldri sa noe». «Hvorfor?» Det var «uhøvelig!» Hun bare hørte på historiene våre, tok dem med hjem og ... Jeg tenkte svært over dette. (Gruppedeltaker/SN-gruppe) 
Dersom man bare sitter og lytter og ikke forteller noe selv, kan man bli mistenkt for å være «nysgjerrig», eller være i gruppa på falske premisser. Det vil trolig oppleves som et brudd på gjensidighetsprinsippet. Talspersoner for SN-modellen pleier å si at «man må ha et problem», og forklarer dette gjerne med at man må selv innse at man har et problem og være villig til å dele dette med resten av gruppa. I AA-gruppene heter det at man må ha et ønske om edruskap - som betyr totalavhold.

I ei gruppe var det en deltaker som indirekte ble anmodet om å slutte fordi vedkommende aldri fortalte noe personlig om seg selv. Hvorvidt en deltakers taushet oppfattes som uakseptabel av de andre, vil nok avhenge av hvordan de tolker denne deltakerens motivasjon for å være i gruppa. Tolkes motivasjonen som sterk og oppriktig, så vil antakelig de andre deltakerne være mer tålmodig og forståelsesfulle overfor en person som har særlig vanskelig for å åpne seg.

Det er ikke bare et spørsmål om taushet eller tale, men også hva man snakker om og eventuelt hvilke måter man bidrar på i gruppa. Det vil være konvensjoner knyttet til hva slags historier man forteller: Historiene skal ikke være upersonlige (de skal ikke innledes med «man» istedenfor «jeg») eller handle om andre («slarv»), og de skal heller ikke være om «løst og fast». Både tema og samtaleform skal være annerledes i ei selvhjelpsgruppe enn i alminnelig sosialt samvær. En deltaker fortalte at de hadde sittet på et møte og spådd i kaffegrut, men hadde da blitt strengt irettesatt av igangsetteren («da fikk vi kjæft»). Ei selvhjelpsgruppe skal være noe kvalitativt annet enn vanlige former for uformelt samvær - det er ikke noe «kaffeslabberas», som en sa.

Mange forteller at de hadde problemer med å snakke om seg selv i starten, at de enten ikke klarte å sette ord på problemet sitt, eller at de var redde for å åpne seg. Deltakelsen i selvhjelpsgruppa innledet en prosess der de gradvis mestret dette og der bekreftelsen og støtten ifra de andre var vesentlig for denne prosessen. En av informantene fortalte at det var en deltaker som innledningsvis ikke klarte å sette ord på sitt problem i det hele tatt, men som endte opp med å ha gjennomgått en stor personlig utvikling takket være selvhjelpsgruppa. Taushet, angst for å snakke, vansker med å formulere problemet sitt etc. diskvalifiserer ikke for deltakelse, kanskje tvert imot. Det er ofte forbundet med selve 
grunnen til at man har behov for å gå i ei gruppe og nettopp derfor kan ha stort utbytte av den.

\section{Alminneliggjøring: «l samme båt»}

Jeg går til psykolog. Han kan si at det jeg sliter med er normalt! Ja vel, så tenker jeg ikke mer på det. Men hvis ei mor har sagt det samme til meg, er det annerledes! Det er noe med å være i «samme båt» og legge ut på den samme veien i lag. Det er derfor jeg blir avhengig av å være her! (Gruppedeltaker/ SN-gruppe)

Gruppedeltakere legger veldig stor vekt på at de kan snakke og utveksle historier med andre som er i samme situasjon som dem og som står på like fot. Flere nevner dette med boklig lærdom, at du kan ikke «lese i boka» hvordan det egentlig oppleves. En sier at det er helt annerledes når psykologen sier noe, f. eks. at det er «normalt» å føle slik og slik, sammenlignet med å høre det fra en annen i gruppa som selv har erfart det samme (se sitat ovenfor). Det virker som om det er først når man kan dele erfaringen med noen, at den fullt ut «alminneliggjøres», og i så henseende vil psykologen komme til kort. Psykologen er ikke «i samme båt.»

Å fortelle og dele med hverandre gjør at man ikke føler seg alene og at man ikke trenger å skamme seg - man «slipper ut dampen». Én sier det slik:

Det er de usagte tingene som ødelegger mest. Idet du har sagt noe, har du sluppet det. Det er som en sånn «dampkoker»! Jeg kan si at «æ har følt skam!» Litt av dampen slipper ut da, men ikke alt. Det er derfor du trenger ei gruppe over tid. Folk er så utrolig redde for å se på seg selv! De er så flinke til å skylde på andre! (Gruppedeltaker/SN-gruppe)

I SN-gruppene opplever deltakerne å møte verbal støtte og forståelse fra de andre. Dette skjer ofte ved at andre forteller om lignende historier og bekrefter at de har den samme erfaringen. Selv om AA-gruppa, i motsetning til SN-gruppa, har en eksplisitt regel om å ikke kommentere det som sies, virker det som om den alminneliggjørende og forsonende effekten 
er den samme her. Rekken av monologer - «AA-fortellinger» (Arminen, 2004; Pollner \& Stein, 1996; Steffen, 1996) - bekrefter at det er et fellesskap mellom de erfaringene som uttrykkes i fortellingene. Å høre sin egen fortelling i sammenheng med de andres lignende fortellinger skaper en opplevelse av å «være i samme båt».

Deltakerne sier det er en sterk opplevelse å kjenne at man «er ikke alene» og at de andre ikke dømmer deg for det du forteller. Alminneliggjøringseffekten er knyttet til at historiene de forteller i gruppa skaper et erfaringsfellesskap mellom deltakerne og fjerner skamfølelsen.

Det tok 10 år for meg å fortelle at jeg sliter med angst, selv til en lege! Mens jeg kan prate helt åpent i ei selvhjelpsgruppe! Når jeg møter naboen min, er det heller ikke slik. Jeg kan ikke fortelle alt til naboen, men i ei selvhjelpsgruppe kan jeg gjerne gjøre det. (Gruppedeltaker/SN-gruppe)

Deltakeren som er sitert ovenfor legger stor vekt på møtet med andre som er i samme situasjon og den terskelen det er å tørre å snakke om problemene sine. Denne personen viser også til nytten av å høre hvordan andre har overvunnet problemene. Samtalene og erfaringsdelingen i selvhjelpsgruppene har åpenbart terapeutisk verdi, og gjensidighetsprinsippet synes å være vesentlig. De verbale utvekslingene kan sees som en sosial samhandlingssituasjon - det Yalom kaller «et sosialt mikrokosmos».

\section{Kollektivisering: gruppa som læringsarena}

I begynnelsen tenkte jeg å slutte, men hva om jeg hadde sluttet da?!? Med den utviklingen som jeg siden har fått! Det er noe helt annet nå! Jeg har fått en helt annen synsvinkel - en ny relasjonsmåte! (Gruppedeltaker/SN-gruppe)

Selvhjelpsgruppene utvikler en kollektiv kunnskap gjennom prosessene deltakerne gjennomgår sammen, som gruppe. Dette handler åpenbart også om å få hjelp av de andre til å finne nye synsvinkler og forlate en «nærsynt» betraktningsmåte på sine egne problemer. Innenfor gruppeterapi kalles dette ofte for «speiling» (se ovenfor). I selvhjelpsgruppesammenheng brukes imidlertid dette i varierende grad, og i AA-grupper skal man i prinsippet ikke gi direkte tilbakemeldinger. En del SN-grupper kan 
imidlertid vektlegge en åpen og direkte, og nokså konfronterende, form, der deltakerne gir reaksjoner på hverandres fortellinger og på hverandres væremåte i gruppa.

Her (i gruppa) kan vi stoppe hverandre og vi kan fornærme hverandre. Vi kan øve på å tørre å stå i situasjonen. Hadde jeg gjort det samme overfor ei venninne, så ville jeg kanskje ha mistet den venninna! (Gruppedeltaker/SN-gruppe)

AA-grupper legger tvert imot stor vekt på å ikke konfrontere eller gi direkte kommentarer på det som blir sagt av en annen deltaker. «Speiling» er en teknikk som kan brukes innenfor 12-trinnsideologien ideologien, men kun innenfor behandlingsinstitusjoner som følger AA-tradisjonen (jf. Minnesotamodellen).

Jeg sier det ikke til de andre, men deler med de andre, for det er viktig å dele! Det er viktig at det blir hørt! Det blir du. (Gruppedeltaker/AA-gruppe)

AA - takk og pris for at det er slik det er! Gruppa fanger opp det vi har snakket om og mye mer. Jeg har et «fristed» der, hvor jeg kan dele det jeg har på hjertet. Jeg kan legge det fra meg - legge det der - punktum! (Gruppedeltaker/AA-gruppe)

Måten selvhjelpsgruppa beskrives på av deltakere, og det gjelder både SNog AA-grupper, tegner et bilde av et «varmt», personlig og støttende fellesskap hvor relasjonene er regulert av moralske koder, ikke kontrakter. Selvhjelpsgruppa har en «gemeinschaft»-karakter som ligner på fellesskap bygget på vennskapsbånd og familietilhørighet. Selvhjelpsgruppa er samtidig mer avgrenset sammenlignet med naturlige «gemeinschaft»-fellesskap, relasjonene er ikke like multiplekse som f.eks. mellom venner. Som tidligere nevnt blir tendenser til «utenomsnakk», «kaffeslaberas» eller sosialt samvær utenom gruppa i stor grad negativt sanksjonert særlig i SN-gruppene.

Siden SN-gruppene synes å ha mer elementer av «speiling», kan reaksjonene fra andre deltakere oppleves som tøffe. I SN-sammenhenger omtales også selvhjelpsgruppene som «treningsstudio» og «øvingsverksted» for sosial samhandling i det virkelige livet. Dette kan handle om å «si ifra», være tydeligere på egne behov og meninger overfor andre, og være «ærlig» overfor sine egne følelser. Det at deltakerne ikke tilhører 
hverandres sosiale nettverk utenom gruppekonteksten, gjør reaksjonene mindre «farlige». Som ei trakk frem; hvis hun hadde sagt det samme som hun sa i gruppa, til ei venninne, så kunne hun ha mista den venninna.

AA-gruppa har som nevnt ikke denne «speilings»-tradisjonen, selv om en del deltakere kjenner til den ifra behandlingsopphold. Rusmisbrukere har som regel en lang historie med å møte fordømmelser fra andre. Ved siden av forpliktelsen på å ønske avholdenhet ligger kanskje den viktigste normen hos AA i å avstå fra enhver form for moralsk dømming av andre deltakere.

AA-fellesskapet strekker seg utover i tid og rom, det avgrenses ikke til selvhjelpsgruppas møter. En AA-deltaker og «tørrlagt alkoholiker»vil kunne gå på et åpent AA-møte hvor som helst i verden og bli tatt imot som en av deres «egne». AA-medlemmer forventes å ha et våkent blikk for andre som «fremdeles lider», men som står utenfor AA-fellesskapet. Han eller hun vil kunne vise andre veien til AA-møtene og være potensiell «sponsor» overfor nykommere. Selv om disse handlingene og relasjonene er preget av diskresjon og anonymitetskulturen i bevegelsen, så peker de altså likevel utover i samfunnet.

\section{Konklusjon}

Selvhjelpsgruppa er et «fristed» der man er skjermet for omverdenens sosiale kontroll og der man kan avsløre egne svakheter uten å risikere konsekvenser på andre, sosiale arenaer og/eller i form av stigma i lokalsamfunnet. Samtidig beskriver gruppedeltakerne et samtalerom hvor man blir utfordret, og konfronterer hverandre. Det er et forum hvor det ikke bare er trøst og støtte å få, men de beskriver selvhjelpsgruppa som et sted der det likevel er trygt å være åpen og direkte.

Jeg har vist at det er et slektskap mellom SN-grupper og AA-grupper, til tross for svært ulik ideologi og arbeidsform. Det er også grunnleggende likheter mellom de selvorganiserte selvhjelpsgruppene, som både AA og SN er, og psykoterapeutiske behandlingsgrupper. Vi kan forstå dette som uttrykk for at viktige deler av selvhjelpsbevegelsen i nyere tid har tatt en psykologisk og terapeutisk dreining, med vekt på selvtransformasjon. 
Samtidig er det liten tvil om at det profesjonelle behandlingstilbudet også har lånt terapeutiske mekanismer fra selvhjelpsgruppetradisjonen. Dialogene mellom «likeverdige» gruppedeltakere og den emosjonelle dynamikken kan ha en effekt som overgår hva psykoterapeuten vil kunne utrette alene. Det er nettopp derfor mange terapeuter utnytter samtalegruppas «sosiale mikrokosmos». Det er fellestrekk mellom terapigrupper og selvorganiserte selvhjelpsgrupper når det gjelder vektlegging av gruppedynamikken, kommunikasjonen mellom lekpersonene og kollektiv læring på bakgrunn av det deltakerne bringer inn i gruppa gjennom sine historier og personlige utleveringer. Modellenes viktigste «terapeutiske prinsipper» er derfor relativt universelle og er felles for ulike former for grupper som har selv-transformasjon som målsetting. Vektleggingen av «her-og-nå»-situasjonen og refleksjonsarbeidet som tar utgangspunkt $\mathrm{i}$ «problemet som ressurs», synes å ha røtter i psykoterapeutiske tradisjoner. Det sterke fellesskapet som mange av informantene forteller om i den selvorganiserte selvhjelpsgruppa, synes å være basert på et erfaringsfellesskap forankret i problemet eller utfordringen som hver enkelt sliter med. Denzin (1993) har kalt dette 'shared emotionality' og mener at den spesielle formen for gjensidig forståelse som gruppedeltakere kan oppleve, forutsetter at man gjenkjenner den andres opplevelse og følelser. Man må selv ha følt det samme «på kroppen» for å kunne forstå.

Anonymitetsprinsippet og gjensidighetsprinsippet viser tilbake til hvordan gruppene i utgangspunktet er konstituert og ment å fungere. Prinsippene kan tolkes ulikt og gis forskjellig utforming, men de synes å inngå som en viktig verdi eller kvalitet ved både selvorganiserte selvhjelpsgrupper og profesjonelt ledete behandlingsgrupper. Vektleggingen av disse prinsippene fremhever «erfaringsbasert kunnskap», samtidig som behandlerens betydning nedtones.

De sosiale arenaene som skapes i henholdsvis ei SN-gruppe, ei AA-gruppe og ei psykoterapeutisk behandlingsgruppe, har grunnleggende fellestrekk i den beskyttende grensen anonymitetsprinsippet skaper. Felles er også tilretteleggingen for ærlighet, selvutleveringer og støtte som følger av gjensidighetsprinsippet. Man kan godt si at løftet om konfidensialitet er en forutsetning for gjensidig åpenhet, mens denne 
gjensidigheten i sin tur garanterer for at konfidensialiteten ikke brytes. Vil en behandler «ødelegge» denne gjensidigheten mellom deltakerne? Yaloms erfaringer tyder ikke på det, og han mener at en lederløs selvhjelpsgruppe må være svært forsiktig med å ta i bruk gruppedynamiske virkemidler (Yalom \& Leszcz, 2005). AAs advarsler mot å gi reaksjoner på hverandres fortellinger («speiling») er således i samsvar med Yalom, men dette deles ikke av SN, som går mye lenger i retning av det Matzat en gang kalte en «psykoterapi uten terapeuter» (Matzat, 2002). SN stiller seg svært kritisk til behandler-ledete selvhjelpsgrupper og mener at dette gjør den til noe annet enn ei selvhjelpsgruppe. Det er gjort lite forskning på hvilken effekt behandleren har på åpenheten og gruppedynamikken i slike grupper. En amerikansk studie fra 1980-tallet undersøkte effekten av å ha behandlere til stede i grupper, og fant at dette hemmet deltakerne i å åpne seg og snakke fritt (Toro et al., 1988). Flere av de intervjuede SN-deltakerne sa at de følte seg friere til å dele erfaringer når det ikke var en behandler til stede, en sa til og med at hun fortalte mer i gruppa enn til psykologen sin.

Koblingen mellom det sosiale rommet i gruppa og samfunnet rundt er nokså forskjellig i de ulike gruppetypene. AA-gruppa har flere direkte forgreininger til samfunnet. AA-gruppa flytter en del av sin egen virksomhet ut i «samfunnet» gjennom utvidete AA-aktiviteter og AA-relasjoner utenfor møtene. Under dekke av sin eksterne anonymitet blir AA-medlemmene «hemmelige forbundsfeller» som kun gir seg til kjenne for hverandre gjennom hemmelige tegn eller på diskre vis avslører sin skjulte identitet overfor potensielle rekrutter. SN-modellen har imidlertid også sine «misjonærer», og de er som oftest selv å regne som «veteraner». Gjennom samarbeidet med myndighetene har de kunnet drive sitt eget samfunnsrettede arbeid og selvhjelpskampanjer. Den ene bevegelsen har således forblitt en undergrunnsbevegelse, mens den nye selvhjelpsbevegelsen promoterer seg selv i fullt flomlys gjennom moderne medier. Begge tilbyr en tilsynelatende effektiv førstehjelp for det plagede selvet - en privat, individrettet reparasjon av psykososiale skader som mange pådrar seg. Men mens AA-bevegelsen opererer på en mer «gammeldags» måte med religiøse begreper, ritualiserte møter og faste kollektive identiteter som «alkoholiker»/«avhengig», så bruker SN-bevegelsen 
terapeutiske termer og gir følelseslivet en sannsigerrolle. Emosjonene, ikke minst reaksjonene som kan inngå i psykiatriske diagnoser, betraktes som en tilgang til et mer autentisk jeg (Andresen \& Talseth, 2000; Axelsen, 1997).

Den samtalebaserte selvhjelpsgruppa er en moderne sosial teknologi (Dean, 2006) som både erstatter, supplerer og avlaster andre offentlige og uformelle hjelpeordninger i samfunnet. Både AA og SN tilbyr deltakerne et beskyttet rom der de kan utvikle seg selv i fellesskap med andre, men uten at dette kollektivet er ment å fremtre offentlig eller reise kollektive krav overfor omgivelsene. Selvhjelpsgruppene er et uttrykk for en ny terapeutisk kultur (Illouz, 20o8); i samfunnet som helhet forventes det at individene arbeider med seg selv og sin egen emosjonelle og sosiale kompetanse. Gruppene er et alternativt, sosialt rom hvor deltakerne tilbys en «øvingsarena» for selvpresentasjoner og mestringsstrategier som senere skal kunne brukes i «samfunnet». Innad virker gjensidighetsprinsippet i relasjonene mellom deltakerne stimulerende for den åpne kommunikasjonen - en ærlig og selvutleverende samtaleform som antakelig ikke ville vært realistisk dersom de andre deltakerne var familie og venner. Av nettopp denne grunn har både SN-gruppa og de psykoterapeutiske gruppene regler som hindrer dem i å utvikle seg til å bli «familie og venner», de er ikke nettverksskapende i en slik forstand. Rammene for gruppas indre virksomhet sikrer likevel at den kan utvikle familielignende kvaliteter som gjensidig forpliktelse, tillit og anerkjennelse (Wuthnow, 1994). Men som gruppedeltakere i ei SN-gruppe eller psykoterapeutisk gruppe forblir man fortrolige fremmede.

\section{Referanser}

Andresen, R. \& Talseth, S. (2000). Gjensidighet og ansvar for eget liv i en selvhjelpsgruppe. I R. Andresen (Red.), Fellesskap og sammenhenger: Yrkeshjelpere i grupper, nettverk og organisasjoner. Oslo: Gyldendal akademisk.

Anonyme Alkoholikere. (2006). Anonyme Alkoholikere «Storboka» (2. utg.) Anonyme Alkoholikere Norge.

Arminen, I. (2004). Second stories: The salience of interpersonal communication for mutual help in Alcoholics Anonymous. Journal of Pragmatics, 36(2), 319-347. Hentet fra $<$ Go to ISI $>$ ://000189094100008 
Arntson, P. \& Droge, D. (1987). Social support in self-help groups: The role of communication in enabling perceptions of control. I T. L. Albrecht \& M. B. Adelman (Red.), Communicating social support (s. 148-171). Newbury Park: Sage Publications.

Axelsen, E. D. (1997). Symptomet som ressurs: Psykiske problemer og psykoterapi. Oslo: Pax.

Bateson, G. (1972). Steps to an ecology of mind. New York: Ballantine Books.

Borkman, T. (1999). Understanding self-help/mutual aid experiential learning in the commons. New Brunswick, N.J.: Rutgers University Press.

Cook, C. C. H. (2006). The Minnesota model in the management of drug and alcohol dependency: Miracle, method or myth? Part I. The philosophy and the programme. B.Sc. MRCPsych. https://doi.org/10.1111/j.1360-0443.1988.tbo2591.x

Dean, M. (2006). Governmentality. Magt \& styring i det moderne samfund. Frederiksberg C: Forlaget Sociologi.

Denzin, N. K. (1993). The alcoholic society: Addiction and recovery of the self. New Brunswick, N.J: Transaction Publishers.

Duncan, B. L., Miller, S. D. \& Sparks, J. (2004). The heroic client: A revolutionary way to improve effectiveness through client-directed, outcome-informed therapy (Rev. utg.). San Francisco: Jossey-Bass.

Illouz, E. (2008). Saving the modern soul therapy, emotions, and the culture of selfhelp. Berkeley, Calif.: University of California Press.

Karterud, S. (1999). Gruppeanalyse og psykodynamisk gruppepsykoterapi. Oslo: Pax.

Matzat, J. (1992a). Selvhjelp for psykiatriske pasienter. I L. Fyrand (Red.), Perspektiver på sosialt nettverk (s. 187-202). Oslo: Universitetsforlaget.

Matzat, J. (1992b). Selvhjelpsgrupper som grunnleggende behandlingsform i psykoterapi og sosialt arbeid. I L. Fyrand (Red.), Perspektiver på sosialt nettverk (s. 180-186). Oslo: Universitetsforlaget.

Matzat, J. (2002). The development of self-help groups and support for them in Germany. International Journal of Self Help \& Self Care, Vol. 1(4) 307-322, 20012002, 1(4), 307-322.

Pollner, M. \& Stein, J. (1996). Narrative mapping of social worlds: The voice of experience in Alcoholics Anonymous. Symbolic Interaction, 19(3), 203-223. Hentet fra $<$ Go to ISI $>$ ://A1996VK60200002

Riessman, F. (1976). How does self-help work? Soc Policy, 7(2), 41-45.

Steffen, V. (1996). Erfaring, Follesskab og Forandring. Minnesota-modellen og Anonyme Alkoholikere i Danmark (Monograph). Københavns Universitet, København.

Toro, P. A., Zimmerman, M. A., Seidman, E., Reischl, T. M., Rappaport, J., Luke, D. A. \& Roberts, L. J. (1988). Professionals in mutual help groups - impact on social climate and members behavior. Journal of Consulting and Clinical Psychology, 56(4), 631-632. Hentet fra <Go to ISI $>$ ://WOS:A1988P 528000027 
Valverde, M. (1998). Diseases of the will: Alcohol and the dilemmas of freedom. Cambridge \& New York: Cambridge University press.

Wampold, B. E. (2001). The great psychotherapy debate. Models, methods, and findings. Mahwah, N.J.: L. Erlbaum Associates.

Wuthnow, R. (1994). Sharing the journey: Support groups and America's new quest for community. New York: Free Press.

Yalom, I. D. \& Leszcz, M. (2005). The theory and practice of group psychotherapy (5th. utg.). New York: Basic Books. 


\title{
KAPITTEL 3
}

\section{Fra frivillig arbeid til folkehelsearbeid - om politisering av selvhjelpssaken}

\author{
Marte Feiring \\ Fakultet for helsevitenskap, OsloMet - Storbyuniversitetet
}

\begin{abstract}
This chapter analyzes the politicisation of self-help groups as a public concern in Norway for the last three decades. The empirical data are three policydocuments, white papers on voluntary work (1992), mental health (1996) and public health (2002) and two national plans on self-help (2004, 2014). Besides, documents published from the self-help activists are analyzed together with interviews with central agents. The research question asks what has been the significance of the different politicisation stages that self-help activities were passing. The article concludes that self-help has undergone a political redefinition from voluntary work to mental and public health work. The dominant actors defining self-help have shifted from social work to a combined enterprise between the health authorities and the Norwegian self-help forum in the planning and regulating of self-help activities at the national level.
\end{abstract}

Keywords: going concern, politicisation, self-help, activists, social entrepreneur

\section{Innledning ${ }^{1}$}

Venstrepolitiker Odd Einar Dørum sier dette om selvhjelp i Stortinget i 2007:

Slik jeg oppfatter selvhjelp, handler det om å prøve å oppnå en større grad av innflytelse og kontroll over eget liv gjennom en felles innsats sammen med

\footnotetext{
$1 \quad$ En tidligere utgave av dette kapittelet er trykket i notatet: Om politisering og læring i selvhjelpsfeltet, Småskrift $2014 \mathrm{nr}$ 1, HiOA/NIBR.
}

Sitering av dette kapittelet: Feiring, M. (2019). Fra frivillig arbeid til folkehelsearbeid - om politisering av selvhjelpssaken. I Å. Brottveit \& M. Feiring (Red.), Samarbeid om selvhjelp. En antologi om den nye selvhjelpsbevegelsen i Norge (s. 69-90). Oslo: Cappelen Damm Akademisk. https://doi.org/10.23865/noasp.68.ch3

Lisens: CC BY 4.0 
andre i tilsvarende situasjoner som den en selv er i. ... Denne selvhjelpsforståelsen bygger på følgende tenkning: en grunnleggende tro på at alle mennesker har livsressurser, og at bevisstgjøring av seg selv i samspill med andre gjør det mulig å ta egne krefter i bruk. Selvhjelp er en viktig del av landets psykiske helsearbeid og et virkemiddel i Opptrappingsplanen for psykisk helse. ${ }^{2}$

Helse- og omsorgsminister Sylvia Brustad, fra Arbeiderpartiet, svarer slik:

Sjølhjelp som metode er, som det er sagt, en måte å hente fram egne ressurser og endre livssituasjonen i en positiv retning til tross for at livet kan oppleves både tungt og vanskelig. Sjølhjelp kan styrke evnen til å mestre eget liv, øke livskvaliteten og bedre menneskers mulighet til å delta i samfunnet. Sjølhjelp er ... et viktig verktøy for å fremme brukermedvirkning, slik jeg ser det. Mestring, deltakelse og brukermedvirkning er ... viktige mål i Opptrappingsplanen. ${ }^{2}$

Denne ordvekslingen fra Stortingets talerstol viser at selvhjelp lenge har vært på den politiske dagsorden i vårt land. Representant Dørum presiserer at selvhjelp er et virkemiddel i opptrappingen av psykisk helsearbeid; statsråd Brustad er enig, og repliserer at selvhjelp kan være et verktøy for å fremme brukermedvirkning og styrke befolkningens psykiske helse.

Kapittelet belyser hvordan selvhjelp er et fenomen som beveger fra å være en personlig samtalegruppe i private omgivelser og helt fram tilå bli et tema i Stortinget. Jeg analyserer dokumenter fra myndigheter og selvhjelpsaktører, og da framtrer det tre delvis overlappende perioder der selvhjelp som tema politiseres: (1) selvhjelp som frivillig arbeid, (2) selvhjelp som psykisk helsearbeid og (3) selvhjelp som folkehelsearbeid. Hensikten med kapittelet er å finne ut hvilke sosiale betydninger det jeg her kaller politiseringsprosesser kan ha for både innhold og organisering av selvhjelpsarbeid.

\section{Analytisk og metodologisk tilnærming}

Jeg betrakter selvhjelp som et fenomen eller sak som beveger seg gjennom ulike politiske stadier. Med begrepet «going concern» retter Hughes

2 http://www.stortinget.no/no/Saker-og publikasjoner/Sporsmal/Interpellasjoner/Interpellasjon/ ?qid=36211; jf. andre og tredje tekstavsnitt, lastet ned i desember 2012. 
(1984) blikket mot sosiale fenomener som skifter form og innhold og som befinner seg i ulike stadier av moralsk og sosial anerkjennelse. Hughes hevder at sosiologiske analyser ofte overser slike fenomener fordi de ikke passer inn i konvensjonelle definisjoner og tilnærminger.

På en beslektet måte er Latour (2007, 2008) opptatt av å forstå politikk prosessuelt. Han antar at enhver sak (her selvhjelpssaken) kan oppfattes som politisk i en eller annen betydning av dette ordet. Han identifiserer fem ulike stadier som en sak kan bevege seg gjennom, og omtaler dette som politisering. Selvhjelpsarbeid kan kalles politisk når det blir synlig i det offentlige bildet, og dette er første stadium hos Latour, dernest, når sivilsamfunnet eller media engasjerer seg i saken omtales det som andre stadium, mens det tredje stadiet inntrer dersom formelle politiske organer engasjerer seg i temaet selvhjelp, eller vurderer om de for eksempel skal finansiere virksomheten. Det fjerde stadiet, ifølge Latour, er når temaet eller saken oppfattes som del av den politiske rådslagingen, mens det siste stadiet er nådd når det tas for gitt at selvhjelp som sak er et offentlig eller politisk anliggende. Enhver offentlig sak kan bevege seg framover eller bakover langs den politiske aksen, samtidig kan den også til enhver tid kan opphøre eller tre ut av offentlighetens lys. Latour er primært opptatt av å belyse saker eller aktiviteter som skjer utenfor tradisjonelle politiske fora og som er lite synlige i offentligheten.

I denne studien analyserer jeg hovedsakelig politiske dokumenter og tekster produsert av norske selvhjelpsaktører som: Angstringen, Studiesenteret for selvhjelp og Norsk selvhjelpsforum. Med støtte i Prior (2003) betraktes dokumenter og tekster som en form for «handlende aktører» - og som dermed gjør noe med en sosial praksis. Nøkkeltekstene er tre stortingsmeldinger: «Om frivillig arbeid» fra 1993-94 (omtalt som Frivillighetsmeldingen), dernest «Åpenhet og helhet: Om psykisk lidelser og tjenestetilbudene» fra 1996-97 (heretter Psykisk helsemelding) og til slutt «Folkehelsemeldingen, Strategier for folkehelsen», som kom i 2002-2003 (heretter Folkehelsemeldingen). I tillegg ser jeg på to nasjonale plandokumenter som omhandler selvhjelpsarbeid (Nasjonal plan for selvhjelp 2004 og 2014). Utover dette studeres tekster produsert av profesjonelle eller sivile aktører i form av FOU-rapporter, seminarrapporter og prosjektrapporter. 
Jeg analyserer nøkkeldokumentene for å se hvordan disse tekstene brukes til å utforme selvhjelpsarbeid (her kalt selvhjelpssaken). Formålet med tekstanalysen er å identifisere hvordan selvhjelpssaken har beveget seg gjennom ulike typer dokument og dermed endret seg fra slutten av 1980-tallet og fram til i dag. Jeg er interessert i hvordan sentrale selvhjelpsaktører, som forfattere av tekster i politikkdokumenter og planarbeider sammen med myndighetene, er med på å konstruere selvhjelpsaktiviteter som et offentlig og politisk saksfelt.

Tekstanalysen er supplert med intervjuer av flere av de sentrale selvhjelpsaktørene (Brinkmann \& Kvale 2015; Silverman, 1985). Intervjumaterialet er hovedsakelig brukt som et utfyllende bakteppe for tolkningen av det skriftlige materialet. En viktig faktor er at de sentrale selvhjelpsaktørene har arbeidet med selvhjelpsaktiviterer gjennom flere tiår og var initiativtakere både til Angstringen (1988) og senere stiftelsen Norsk selvhjelpsforum (1998). Samtidig har de samme aktørene vært sentrale tekstleverandører til de nevnte stortingsmeldingene, og de har deltatt i utformingen av de to nasjonale planene for selvhjelp som også er del av dokumentmaterialet i denne studien. Sist, men ikke minst, har de samme sentrale selvhjelpsaktørene samarbeidet med myndighetene om utformingen og oppfølgingen av dette forskningsprosjektet. I innledningskapittelet redegjør vi for de metodiske utfordringene knyttet til denne relasjonen. For å kvalitetssikre tolkningen av datamaterialet har sentrale aktører innen selvhjelpsområdet kommentert tidligere utkast av dette kapittelet.

\section{Kort historisk ramme}

Både Katz og Bender (1976) og Schubert og Borkman (1991) har lansert selvhjelpstypologier med utgangspunkt i nordamerikansk kontekst. Thuen har sammen med Carlsen (1998) oversatt og tilpasset Schubert og Borkmans (1991) typologi til norske forhold. De tar utgangspunkt i gruppers organisasjonsform, relasjon til profesjonelle og bruk av ulike typer kunnskap.

Sett $\mathrm{i}$ et lengre historisk perspektiv kan vi si at de første selvhjelpsgruppene i vårt land var i regi av sivile organisasjoner. En tidlig aktør er 
brukerorganisasjoner og interesseorganisasjoner, som stod for etablering av selvhjelpsgruppearbeid rundt århundreskiftet, og mye av deres arbeid ble omtalt som likepersonsarbeid på 1980- og 90-tallet (NOU, 1992:1). I de første etterkrigsårene etablerte Anonyme Alkoholikere (AA) selvhjelpsgrupper i Norge, mens i løpet av 1950- og 6o-tallet tok ulike fagprofesjoner og velferdsinstitusjoner i bruk former for selvhjelpsgrupper (Matzat, 2007). Flere frivillige organisasjoner hadde sin storhetstid på 1970- og 8o-tallet, som for eksempel prosjektet Sorg og omsorg. Angstringen er et eksempel på en nyere type selvhjelpsorganisasjon (Feiring, 2013). Alle de nevnte organisasjonene og selvhjelpsgruppene eksisterer i Norge i dag.

Fra flere nordiske land har samfunnsforskere forsøkt å avgrense selvhjelp og selvhjelpsgrupper som fenomen. Høgsbro $(1992,2012)$ har definert og typologisert selvhjelp i dansk kontekst, mens Karlsson (2002, 2006) har arbeidet med å avgrense selvhjelpsfenomenet i Sverige. Hedlund og Landstad (2012) skriver at Borkman (1976, 1999), Høgsbro (1992) og Karlsson (2006) anvender ulike selvhjelpsbegrep og at de har delvis ulike forståelser av selvhjelp. I likhet med de andre nordiske samfunnsforskerne formulerer Hedlund og Landstad (2012) en norsk definisjon av selvhjelp og selvhjelpsgrupper. ${ }^{3}$ Mitt anliggende i dette kapittelet er noe annerledes; jeg er snarere opptatt av hvilke forståelser og avgrensninger av selvhjelpsfenomenet som kan identifiseres i tekster og dokumenter i Norge fra tidlig 1990-tall og fram til i dag.

Før 1945 kan vi si at ordet selvhjelp hovedsakelig er brukt i to betydninger i Norge: a) om "prinsippet hjelp til selvhjelp» og b) om selvhjelpsforeninger eller organisasjoner. Gjennom sosialhistorien anvendes «prinsippet hjelp til selvhjelp» om det å yte ekstern hjelp slik at de trengende kan bli selvstendige. Et eksempel på dette er kollektiv hjelp til håndverkere og industriarbeidere under sykdom og ved tap av arbeidsinntekt. «Selvhjelpsforeninger» er et ord som kan knyttes til utsatte grupper som døve eller blinde som kom sammen for å hjelpe hverandre. Gjennom

3 Hedlund og Landstad (2012, s. 65) skriver: «The term self-help refers to methods, skills, and strategies by which individuals direct their activities toward the achievement of self-help, including goal-setting, decision-making, self-evaluation, self-intervention, and self-development, etc. The term self-help group refers to the context of an organized setting that provides an environment for social interactions through group activities and mutual support for the purpose of self-help agency by means of self-help and self-care». 
felles skolegang ble personer med manglende hørsel eller syn kjent med likesinnede, og de utviklet nettverk for støtte og selvhjelp (Høgsbro, 1992; Thuen \& Carlsen, 1998). ${ }^{4}$ Etter andre verdenskrig tok velferdsstaten gradvis over mange av disse oppgavene, og selvhjelpsaktørene endret seg fra å være opptatt av personlig bistand til mer sosialpolitiske temaer (Matzat, 1992, 2007).

Som vist i innledningskapittelet skjer det i løpet av 1980-årene en ny satsing på selvhjelpsarbeid i regi av sivilsamfunnet i Norge, og flere forskere identifiserer en økt bruk av frivillig arbeid sammen med offentlig velferd (Kuhnle \& Selle, 1990). Dette begrunnes delvis ved at velferdsstaten er i en form for «krise», og at det er tverrpolitisk enighet om at offentlig vekst i samme tempo som tidligere ikke lenger er mulig. I motsetning til de første tiårene etter krigen, kan vi se et skifte fra «velferdsstat til velferdssamfunn». Dette skiftet er blant annet basert på at sivilsamfunnet tillegges flere oppgaver i form av tjenester til befolkningen. De nye selvhjelpsaktørene, som studeres her, kan sees som et eksempel på dette.

Hjemdal (1996, s. 7) skriver at selvhjelp, i betydningen gjensidig hjelp, er et fenomen som har eksistert til alle tider: «Vi har samarbeidet om å finne løsninger og vi har støttet hverandre i trange tider». Samtidig peker han på en viktig forskjell mellom tidligere tiders selvhjelp og dagens virksomhet; gjensidig hjelp var i tradisjonelle samfunn basert på nærhet og slektskap, der de som bodde i samme nabolag eller arbeidet sammen, var med i samme foreninger og laug. Dette omtales i dag som sosiale nettverk. Dagens selvhjelpsarbeid er tuftet på det motsatte, nemlig at de som søker fellesskap og deltar i selvhjelpsgrupper, i utgangspunktet er fremmede for hverandre (Brottveit, 2013). Selvhjelp er i dag basert på en ny type intimitet og representerer slik sett et noe annerledes fenomen (Giddens, 1991).

Videre drøfter Hjemdal (1996) de sammensatte relasjonene mellom selvhjelpsaktører, veldedige organisasjoner og offentlige institusjoner og karakteriseres dette som en kamp om selvhjelpens ideologiske sjel. Det skjedde en gradvis dreining av selve holdningen til sivilsamfunnets organisasjoner etter andre verdenskrig, samt en endring i retning av

4 I 1900 dannet tidligere elever ved blindeskolen «De blindes selvhjelpsforbund» og noen år tidligere (1878) ble Døveforbundet stiftet. 
en allmenn interessefremming i sosialpolitisk arbeid. Under Arbeiderpartiets mangeårige styre fikk tradisjonelle frivillige organisasjoner etter hvert mindre støtte enn kooperative ordninger. De første tiårene etter andre verdenskrig var det liten vekst innen selvhjelpsaktiviteter, med unntak av Anonyme Alkoholikere, som ble dannet på slutten av 1940-tallet. Utviklingen endret seg i løpet av 1960- og 70-årene, samtidig med en framvekst av det vi i dag omtaler som frigjørende bevegelser basert på sosialpsykologi, deltakelse og en ideologi om empowerment. ${ }^{5}$

Denne korte historiske gjennomgangen viser at framveksten av selvhjelpsarbeid kan betraktes som et produkt av den generelle samfunnsutviklingen. Som vi viser i innledningskapittelet, handler det om endringer i sosiale relasjoner, endringer i synet på autoriteter og profesjoner, nye ordninger innenfor det offentlige og profesjonelle hjelpeapparat og en økende innsats fra sivilsamfunnet.

\section{Selvhjelp som sivilsamfunnsaktivitet}

På slutten av 1980-tallet tas det flere nye selvhjelpsinitiativer i Norge. I 1986 dannes det hele tre nye selvhjelpsaktører: Anonyme Narkomane, Angstringens forløper - Bare angst og prosjektet Sorg og omsorg, mens året etter opprettes Interessegruppa for kvinner med spiseforstyrrelser (IKS). Denne nye formen for sivilsamfunnsaktivitet kan, ifølge Latour (2007, 2008), omtales som et første stadium i politiseringen av selvhjelpssaken. Når et personlig eller privat anliggende, som for eksempel angst, blir tematisert som ved selvhjelpsinitiativet «Bare angst», har politiseringen av selvhjelp som fenomen startet. Angst er ikke et nytt fenomen, det har vært tematisert siden Kierkegaard ga ut boka «Begrebet angest» for over 150 år siden (Kierkegaard, 1981). Vi kan si at temaet angst har beveget seg fra å være et personlig, eksistensielt anliggende, til noe som kan behandles av profesjonelle hjelpere, eller til noe man forsøker å håndtere

$5 \quad$ Eksempler på dette er: studentbevegelsen, kvinnebevegelsen og funksjonshemmedes interesseorganisasjoner. De var alle stimulert av store internasjonale motbevegelser som vokste fram på 1950- og 6o-tallet. Freire (1973 [1968]) med boka: «De undertryktes pedagogikk», arbeidet med Sør-Amerika som utgangspunkt, mot sult, fattigdom og analfabetisme; mens borgerrettighetsbevegelsen i USA arbeidet for sosiale og politiske rettigheter for de sorte. Det handlet om å bedre livsvilkår og rettigheter for marginale grupper. 
sammen med andre personer med de samme eksistensielle problemene (Eidheim 2000).

Et offentlig initiativ, som ledet til en tydelig politisering av selvhjelpssaken, kan spores til opprettelsen av Studiesenteret for selvhjelp i 1992, under ledelse av Sosialhøgskolen i Oslo. I tre år finansierer statlige myndighetene Studiesenteret - som i praksis var organisert som et aksjonsforskningsprosjekt. En av senterets oppgaver var å kartlegge omfang av og innhold i selvhjelpsaktiviteter i Norge. Studiesenteret var lokalisert sentralt i Oslo, og på det meste benyttet 20 selvhjelpsgrupper og 9 organisasjoner senterets lokaler til møter og gruppevirksomhet (Hjemdal, Nilsen, Riiser \& Seim, 1996).

Studiesenteret karakteriserer sin virksomhet som et flerstrenget system og anbefaler en mangfoldig organisatorisk struktur for denne form for sivil aktivisme (Hjemdal et al., 1996). I rapporteringen og analysen av prosjektet anbefaler Hjemdal et al. at det opprettes et sentralt organ for å ivareta de koordinerende oppgavene, og samtidig presiseres det at de ulike selvhjelpsaktivistene må oppleve den koordinerende enheten som sitt eget organ. Om den uavhengige rollen til Studiesenteret kan vi lese følgende:

Vi tror dette er svært viktig i et felt som er preget av til dels uttrykte motsetningsforhold mellom offentlige instanser og enkelte grupper og organisasjoner, og til dels også ideologiske, verdimessige og praktiske motsetninger mellom enkelte grupper og organisasjoner. (Hjemdal et al., 1996, s. 264)

Under overskriften «Nasjonalt nettverk for selvhjelp» anbefaler rapporten videre at offentlige myndigheter støtter opp om den grasrotorganiseringen som allerede eksisterer. Samtidig presiseres det at de ulike organisasjonene trenger å utvikle en «felles forståelse» for hva selvhjelp er, slik at de aktuelle selvhjelpsaktørene skaper en felles identitet. For å komme i gang med dette arbeidet trengs offentlige og frivillige støttespillere: frivillighetssentraler, kommuner, menigheter og individuelle, profesjonelle aktører (Hjemdal et al., 1996, s. 266).

Etter at det statlige Studiesenterets prosjektperiode er over, organiserer selvhjelpsaktørene seg i en nettverksgruppe som arrangerer tre seminarer: Selvhjelp på norsk, Selvhjelp på norsk 2 og Selvhjelp på norsk 3. Denne 
seminarrekken kom i stand ved at flere av aktivistene og noen fagfolk fra selvhjelpsvirksomheten dannet en felles arena for å utveksle erfaringer om hvordan de eventuelt kunne skape et forum for framtidig arbeid (de omtaler seg som seminargruppa). Dette er et eksempel på at selvhjelp er en sak der statlige myndigheter, fagfolk og selvhjelpsaktører har ulike oppfatninger om hvordan selvhjelp skal defineres, og om hvem som skal ha makt til å bestemme dette. Ifølge Latour er dette stadium to, altså før selvhjelpssaken er institusjonalisert som et offentlig anliggende.

En bredt definert selvhjelpsvirksomhet er beskrevet i Frivillighetsmeldingen (Sosial- og helsedepartementet, 1993). Der står det følgende:

I selvhjelpsgrupper kommer mennesker sammen og arbeider med et felles problem. Hensikten er først og fremst å gjøre noe med eget problem, selvhjelpsprinsippet, slik at personlig vekst og utvikling blir mulig. Det dreier seg om vekst med utgangspunkt i den enkelte deltakers erfaringer og selvhjelpsprosess. Den enkelte må ta et aktivt valg og bevege seg fra en passiv mottakerrolle til aktiv deltakerrolle. Ved å oppleve og høre hvordan andre takler sin situasjon kan en selv få impulser til å gå videre med det som er vanskelig ut fra sine egne muligheter og begrensninger. I selvhjelpsgrupper er alle givere og mottakere på samme nivå. (Sosial- og helsedepartementet, 1993, kap 3.6, annet avsnitt)

Det som er interessant i vår sammenheng, er at dette sitatet fra Frivillighetsmeldingen stammer fra Angstringens erfaringsspredningsprosjekt og samarbeid med myndighetene. Det er forfattet av de sentrale aktørene i Angstringen. I denne stortingsmeldingen er hele 3-4 sider viet selvhjelp som tema. Under overskriften: Selvhjelpsgrupper og likemannsarbeid presenteres flere av de nye selvhjelpsaktørene fra 1986 og 1987 utførlig. Det gjelder: samarbeidsprosjektet Sorg og omsorg, Angstringen og Interessegruppe for kvinner med spiseforstyrrelser (IKS), samt det da nystartede Studiesenteret for selvhjelp. De nyopprettede frivillig(hets)sentralene omtales som møteplasser for selvhjelpsgrupper.

Jeg vil si at selvhjelpsarbeidet på mange måter endrer karakter utover på 1990-tallet, fra å være et grasrotinitiativ til å bli en anerkjent virksomhet innen frivillighetssektoren i Norge. Selvhjelpsaken beveger seg altså fra å være en privat og personlig affære til å bli en del av det offentlige. Dette kan beskrives slik: For det første støtter myndighetene opprettelse 
av frivillig(hets)sentraler og danner et eget Studiesenter som skal kartlegge og videreutvikle selvhjelpssaken. For det andre flytter selvhjelpsgruppa fra private til offentlige lokaliteter. For det tredje blir selvhjelp som sak og tema omtalt og beskrevet $\mathrm{i}$ en stortingsmelding om frivillig arbeid.

I tråd med Latour (2008) er en sak politisk når den oppfattes som et offentlig anliggende. Slik sett kan selvhjelpssaken, i tråd med den beskrivelsen som er gitt her, karakteriseres som en bevegelse fra første til tredje stadium - der politikerne fatter interesse i fenomenet selvhjelp. Når et fenomen beveger seg over i nye konstellasjoner, leder dette ikke bare til en fysisk overføring til nye kontekster, men også til en refortolkning av selve saksinnholdet. Slike transformasjoner omtaler Latour som «oversettelser». Det betyr at når selvhjelpsaktiviteter organiseres av en utdanningsinstitusjon, i form av et aksjonsforskningsprosjekt med sterk sosialfaglig kompetanse, så skjer det en form for oversettelse i Latours betydning. Selvhjelpsaktivitetene ved Studiesenteret omfatter både samtalegrupper og aktivitetsgrupper, den dekker somatiske, sosiale, psykiske og rusrelaterte problemer i befolkningen. Studiesenteret står altså for en relativt bred fortolkning av selvhjelp, men dette senteret ble ikke oppfattet som selvhjelpsaktørenes eget forum.

\section{Selvhjelp som psykisk helsearbeid}

Midt på 1990-tallet omtales selvhjelp oftere som psykisk helsearbeid, og dette tolker jeg som et produkt av den nye politiske satsingen på området. Det er ikke nødvendigvis noen motsetning mellom selvhjelp som frivillig arbeid og som psykisk helsearbeid, men det nye er at aktørene som arbeider med selvhjelp som psykisk helsearbeid, grupperer seg sammen, mens tidligere selvhjelpsaktiviteter, som somatiske og mer sosialt orienterte grupper, skilles ut. Det vi kaller den nye forståelsen av selvhjelp handler i stor grad om forebygging av psykiske problemer.

Psykisk helsearbeid løftes fram på den politiske dagsorden gjennom en stor nasjonal satsing - Opptrappingsplanen for psykisk helse. Denne perioden omtales som et helsepolitisk og helsefaglig skifte fra psykiatrisk institusjonsbehandling til et mer lokalt orientert psykisk helsearbeid. 
For å få til denne snuoperasjonen lanseres en egen opptrappingsplan for psykisk helsearbeid. I stortingsmeldingen «Åpenhet og helhet: Om psykiske lidelser og tjenestetilbudene» er begrepet selvhjelp omtalt flere ganger (Sosial- og helsedepartementet, 1997). Selvhjelpsbegrepet blir bredt beskrevet med henvisning til tre forskjellige typer aktiviteter: (1) det tradisjonelle prinsippet «hjelp til selvhjelp», (2) selvhjelp etablert eller drevet av tidligere medlemmer av selvhjelpsgrupper og (3) de mange ulike brukerforeningene som igangsetter selvhjelpsrelaterte aktiviteter som en del av sin øvrige portefølje (Sosial- og helsedepartementet, 1997).

Sammenlignet med Frivillighetsmeldingen fra 1993-94 presenterer stortingsmeldingen om psykisk helsearbeid en mer flertydig forståelse av fenomenet selvhjelp. Dette vil jeg presisere nærmere. I stortingsmeldingen om psykisk helsearbeid beskrives selvhjelp som: hjelp til selvhjelp, brukerforeningenes selvhjelpsforståelse (i dag likepersonsarbeid) og det vi kan kalle selvhjelpsaktørenes selvhjelpsforståelse (jf. Angstringen i Frivillighetsmeldingen). Selv om forståelsen av selvhjelp er vid, avgrenses den altså til psykisk helsearbeid. Det betyr ikke at somatiske og sosialt orienterte selvhjelpsaktiviteter ikke lenger eksisterer, men at aktivistene bak seminarene Selvhjelp på norsk orienterer seg i ulike retninger, og at det er de som arbeider med selvhjelp relatert til psykisk helsearbeid, som oppnår størst offentlig oppmerksomhet.

I forbindelse med Opptrappingsplanen for psykisk helse inviterer Sosial- og helsedepartementet sivile aktører og brukerforeninger til et samarbeid. Målet med det nye samarbeidet beskrives som å myndiggjøre brukere, øke kontaktflaten med offentlige helsetjenester samt styrke nettverksbygging innen interesseorganisasjonene for å sikre forankring av det framtidige samarbeidet. Det ideologiske forbildet er empowerment-bevegelsen fra USA (Bjørgen, 2012; NOU 1998:18, 1998).

Dette statlige initiativet leder til samarbeidsgruppa «På egne vegne», med deltakere fra Mental Helse, Funksjonshemmedes Fellesorganisasjon (FFO) og Angstringen - i tillegg til flere offentlige og profesjonelle aktører. Angstringen er den eneste deltakeren fra den tidligere omtalte seminargruppa fra 1995 som er med i det nye samarbeidet. I motsetning til aktivistene som arrangerte seminarene Selvhjelp på norsk, og som bestod primært av aktører som arbeidet direkte med selvhjelp og 
selvhjelpsgrupper, er den nye samarbeidsgruppa sammensatt av brukerorganisasjoner, frivillige, faglige og offentlige aktører.

Samarbeidsgruppa «På egne vegne» er primært opptatt av brukere av psykiske helsetjenester - deres erfaringer og medvirkning i egne tjenester. Inspirert av empowerment-tankegangen fremmer samarbeidsgruppa $ø n s k e t$ om et koordinerende senter styrt av brukere innen psykisk helsearbeid. Aktivistene er engasjert i brukerstyring og foreslår at alle ansatte ved senteret skal ha brukererfaringer. Mens det tidligere Studiesenteret var administrert av en statlig utdanningsinstitusjon, er den nye samarbeidsgruppa opptatt av at verken profesjonelle eller offentlige autoritetspersoner skal utføre kjernevirksomhet ved senteret. Dette beskrives slik:

Forutsetningene for å realisere dette er bl.a. at det foregår samarbeid mellom brukerorganisasjoner, interessegrupper, selvhjelpsgrupper og Sosial- og helsedepartementet. Erfaringer hos brukerne, deres organisasjoner og grupper vil bli samlet og systematisert i det nasjonale senteret. Senterfunksjonene og funksjonelle IT-løsninger skal hjelpe til å fremme bruk av kunnskapene i møte med hjelpere, i organisasjonsutvikling og i kompetanseutviklingsarbeid. (NOU 1998:18 (1998), s. 199-200)

Dette leder til etableringen av ytterligere en ny arbeidsgruppe, bestående av brukere- og pårørendes organisasjoner samt selvhjelpsaktører som har til mandat å utrede et eget brukerstyrt senter, nå kalt Nasjonalt egenkraftsenter (NEKS). Senteret skulle arbeide med brukerinnflytelse og ulike former for selvhjelpsarbeid (Bjørgen \& Jahn, 2001, s. 17, 19). Til sammen deltar seks ulike organisasjoner i dette utviklingsarbeidet og Mental helse sitter i førersetet (Bjørgen \& Jahn, 2001). I utredningen fra denne gruppa står det:

NEKS må ha sin forankring i et levende brukermiljø som viser at det er i stand til å synliggjøre og praktisere brukerinnflytelse og kompetanse, og som samtidig har et aktivt forhold til kvalitetssikring av behandling innenfor det psykiske helsevern. Dette vil også kunne være et miljø som sikrer egenkraft og utvikling av ulike former for selvhjelpsarbeid, både på individuelt nivå og på gruppenivå.

(Bjørgen \& Jahn, 2001, s. 5)

Det er interessant for vårt tema at den brukerstyrte arbeidsgruppa avgrenser selvhjelpssaken på en ny måte. For det første handler det nå om «å utvikle 
selvhjelparbeidet for psykisk helse» (Bjørgen \& Jahn, 2001, s. 6), og dette er smalere enn Studiesenterets mandat. For det andre framheves et større mangfold i defineringen av begrepene «selvhjelp» og «brukerinnflytelse», som for eksempel at de skal anvendes på individ-, gruppe- og samfunnsnivå. Sist, men ikke minst, det nye brukerstyrte senteret skal arbeide med systematisering av erfaringene fra selvhjelpsaktiviteter, og «brukerstyrking gjennom å spre metoder for selvhjelpsarbeid» (Bjørgen \& Jahn, 2001, s. 8).

Vektleggingen av psykisk helsearbeid skaper altså helt nye samarbeidsformasjoner for selvhjelpssaken (NOU 2001:22, 2001; Sosial- og helsedepartementet, 1997; Stortinget, 1998). Den videre prosessen kan beskrives som en transformasjon langs to dimensjoner: For det første omdefineres selvhjelpssaken fra sivilsamfunnsaktivitet til psykisk helsearbeid, og som en del av myndighetenes Opptrappingsplan for psykisk helse. Dernest, og delvis som en konsekvens av dette, er de tidligere sosialfaglige aktørene ikke lenger med i samarbeidet, mens aktører fra arbeid med mental helse blir er en del av det nye nettverket innen psykisk helsearbeid. Selvhjelp er gjennom den store satsingen på psykisk helsearbeid blitt betydelig politisert og nærmer seg stadium tre i Latours typologi.

I denne perioden utfordres samarbeidet mellom selvhjelpsaktører og brukerorganisasjoner innen psykisk helsearbeid. Mental Helse arbeider videre med idéen om et eget kompetansesenter for systematisering av brukererfaringer og bedre tjenesteutvikling innen psykisk helsearbeid, mens stiftelsen Norsk selvhjelpsforum videreutvikler temaet selvhjelp.

\section{Selvhjelp som folkehelsearbeid}

En ny faglig og politisk innramming av selvhjelpssaken omtales tidlig i notatet Selvhjelp i folkehelsearbeid (Eidheim, 200o). Det er ikke mulig å foreta en entydig avgrensning mellom psykisk helse og folkehelse. På den ene siden kan en si at psykisk helse er en del av folkehelsen; og på den annen side kan folkehelsebegrepet brukes for å overskride skillet mellom somatisk, psykisk og sosiale helse. Samtidig rettes folkehelsearbeid, i betydningen forebyggende og helsefremmede arbeid, mer mot hele befolkningens helsetilstand enn mot enkeltpersoners helseplager. 
I folkehelsemeldingen «Resept for et sunnere Norge» (Helse- og omsorgsdepartementet, 2003) kan vi lese følgende om en plan for selvhjelp:

Det overordnede målet med den nasjonale planen er å styrke selvhjelpsarbeidet. Satsingen skal bidra til at tidligere erfaringer fra selvhjelpsrelatert arbeid og prosjekter tas i bruk og utvikles videre, og at selvhjelpsarbeidet i eksisterende nettverk styrkes. Planen skal på overordnet nivå bidra til å bygge opp og legge til rette for strukturer som sikrer at selvhjelpsarbeidet styrkes og videreføres etter 2006. Målet er å gjøre selvhjelp som metode tilgjengelig for flere, fremme systematisk kunnskap og metodeutvikling om selvhjelp og bidra til at selvhjelp som verktøy kan brukes innen psykisk helsearbeid, både for brukere og hjelpere. (Helse- og omsorgsdepartementet, 2003, s. 58)

Folkehelsemeldingen omtaler, i tråd med tidligere meldinger, selvhjelp som en metode for å oppnå bedre psykisk helse. Den viser samtidig til et landsdekkende program for selvhjelp - en nasjonal plan. Denne planen er initiert og langt på vei skrevet av selvhjelpsaktørene i Norsk selvhjelpsforum (NSF). De utarbeidet tidlig et forslag til nasjonal plan på oppdrag av Sosial- og helsedepartementet (Sosial- og helsedirektoratet, 2004).

I den første nasjonale planen for selvhjelp står det at selvhjelpsbegrepet er anvendt ulikt i forskjellig sammenhenger (Sosial- og helsedirektoratet, 2004). Den nasjonale planen knytter selvhjelp til folkehelsearbeid og er opptatt av å introdusere selvhjelpsgrupper til befolkningen så vel som til tjenesteapparatet. Ved å koble selvhjelparbeidet til en utvidet helseforståelse blir flere inkludert, og et bredere grunnlag for selvhjelpsgrupper etableres. Dette til tross, selvhjelpssaken er i dag betydelig smalere definert enn tidlig på 1990-tallet. I perioden fram til den reviderte nasjonale planen (2014) avgrenses selvhjelpsbegrepet ytterligere, og i dag anvender kompetansesenteret, Selvhjelp Norge, ordet «selvorganisert selvhjelp» om sin virksomhet. ${ }^{6}$ Denne presiseringen kan se ut som et paradoks, da statlige myndigheter i større grad enn tidligere er involvert i selvhjelpsarbeidet.

Nasjonal plan for selvhjelp (2004) stadfester at et nytt koordinerende organ for selvhjelpsaken, finansiert av myndighetene, vil bli opprettet.

6 https://helsedirektoratet.no/Lists/Publikasjoner/Attachments/30o/Nasjonal-plan-for-selvhjelp-
2014-2018-IS-2168.pdf, lastet ned i april 2015. 
Det er langt på vei Norsk selvhjelpsforum som har formulert målene og strategiene i planen. Representanter fra dette forumet sier i et intervju:

Dette er som nevnt jobbet fram nedenfra, fra folk som har vært engasjert i selvhjelpsarbeidet. Gjennom offentlig finansierte selvhjelpsprosjekter siden 1980-tallet har det blitt dokumentert behov for nasjonal satsning og forankring for å sikre videre utvikling, rammer, og vekst og ytterligere bruk av den erfaringsbaserte kunnskapen selvhjelpsarbeidet representerer. Planen ble laget for å ta i bruk de erfaringer som faktisk var gjort. For å få dette til, var en plan med politisk forankring nødvendig. Det har altså vært en kombinasjon av strategisk arbeid fra selvhjelpsentreprenører, kombinert med politisk ønske om å ta menneskers erfaringsbaserte kunnskap i bruk. (Aktør i Norsk selvhjelpsforum)

I nasjonal plan (2004) blir tidligere forslag om utvikling av selvhjelpssaken gjentatt, men nå som Helsedirektoratets egen plan. Ett av forslagene er å danne et nasjonalt senter for selvhjelp. Det nye senteret får et omfattende mandat: 1) generere og formidle kunnskap og sørge for informasjon om selvhjelp, herunder «selvhjelpsverktøy», 2) opptre som koordinator for selvhjelpsnettverk og 3) arbeide for bedre økonomisk støtte, inklusive finansiering av forskning.

Helsedirektoratet delegerer oppdraget om å lede det nye nasjonale senteret, Selvhjelp Norge, til Norsk selvhjelpsforum, som altså selv hadde formulert teksten til den nasjonale planen.7 På hjemmesiden til det nyetablerte senteret kan vi lese:

Selvhjelp Norge ble etablert i april 2006 og er et sentralt virkemiddel i arbeidet med å nå målene i Nasjonal plan for selvhjelp. ... Selvhjelp Norges visjon er at alle i Norge skal vite hva selvhjelp er og kunne ta kunnskapen i bruk når problemer oppstår. ${ }^{8}$

De sentrale aktørene i stiftelsen Norsk selvhjelpsforum har hele tiden vært opptatt av at selvhjelpsgrupper ikke skulle bli en del av det offentlige tjenestetilbudet:

http://www.selvhjelp.no/Om_oss/Nodal_point_of_self_help/, lastet ned i november i 2010.

http://www.selvhjelp.no/no/Om_oss/Selvhjelp_Norge/, lastet ned i november 2011. 
Vi ønsker ikke at selvhjelp skal bli en del av velferdssystemet, men en naturlig brikke i helsearbeidet. Selvhjelp er et selvstendig arbeid, men vi ønsker at det skal bli en synlig og tydelig del av samfunnsbildet. ... Vi ønsker at selvhjelp skal være en selvstendig del av samfunnet. (Aktør i Norsk selvhjelpsforum)

Samtidig uteblir deltakelsen fra andre frivillige organisasjoner, brukerorganisasjoner og andre selvhjelpsaktører. Aktørene fra samarbeidet om psykisk helsearbeid, med Mental helse i spissen, har etablert et nasjonalt senter for erfaringskompetanse innen psykisk helse, med en egen nettside, erfaringskompetanse.no. De presenterer dette slik:

Vi har fått i mandat fra Stortinget å samle, gjøre gyldig og formidle kunnskap og gjøre den tilgjengelig for helsesektoren. Kompetansesenteret som er finansiert av Helsedirektoratet, er en brobygger i møtet mellom erfaringskompetanse og fagkunnskap innen psykisk helse. Vi utfordrer både den erfarings- og fagbaserte kunnskap[en] og ønsker å fremme et helhetlig bilde av helsehemmende og helsefremmende faktorer innen psykisk helse. ${ }^{9}$

Vi ser her at de to sentrale aktørene bak Nasjonalt Egenkraftsenter nå har etablert hvert sitt kompetansesenter i samarbeid med helsemyndighetene. Begge sentrene er fortsatt virksomme i 2019, og det er noe samarbeid mellom de to aktørene ved at Nasjonalt senter for erfaringskompetanse har en representant fra Norsk selvhjelpsforum i sitt styre.

Med en nasjonal plan vedtatt av helsemyndighetene $(2004,2014)$ og et nasjonalt kompetansesenter for selvhjelp, finansiert over statsbudsjettet, er selvhjelpssaken ytterligere politisert og institusjonalisert (Helsedirektoratet, 2014; Sosial- og helsedirektoratet, 2004). Norsk selvhjelpsforum er en smalere organisasjon enn på stiftelsespunktet (1998), og de representerer ikke bredden av selvhjelpsaktører. Både nettverket, som stod bak seminarene Selvhjelp på norsk på 1990-tallet, og aktørene bak Nasjonalt egenkraftsenter rundt år 2000 hadde en betydelig bredere representasjon fra ulike sivile organisasjoner i ledende organer enn dagens nasjonale kompetansesenter.

Den nasjonale selvhjelpsplanen og det nasjonale kompetansesenteret er eksempler på samarbeid mellom statlige og sivile organer og kan

9 http://www.erfaringskompetanse.no/oss, lastet ned i januar 2014. 
dermed kalles en type samproduksjon (Feiring, 2019; Hunter \& Ritchie, 2007; Røiseland \& Vabo, 2008). Det er færre aktører fra sivile bevegelser som er aktivt med i styringen av selvhjelpsvirksomheten ved kompetansesenteret i dag, sammenlignet med tidligere. Samtidig har den politiske defineringen av selvhjelp som folkehelsearbeid bidratt til å utvide hvilke problemområder som kan tematiseres i en selvhjelpsgruppe.

\section{Diskusjon og konklusjon}

Selvhjelp som fenomen og sak slik den er beskrevet i politiske dokumenter og planer, beveger seg gjennom ulike politiske stadier. Denne bevegelsen har vi belyst her ved å lese ulike tekster om hvordan selvhjelpsaken er definert og konstruert. I de siste tre tiårene har selvhjelpssaken endret seg fra å være et rent privat anliggende til å bli en del av det frivillige arbeidet tidlig i 1990-årene og derfra til det psykisk helsearbeidet i løpet av 1990-tallet; mens i dag er selvhjelpsaktiviteter gjerne definert som del av det helsemyndighetene omtaler som folkehelsearbeid.

I den første fasen, der selvhjelp er omtalt som en sivilsamfunnsaktivitet, er det særlig sosialfaglige aktører på banen, mens det er først i de neste periodene at brukerorganisasjonene blir sentrale i politiseringen. Fra midten 1980-tallet beveger selvhjelpssaken seg fra privatsfæren til frivillighetsarbeid og frivillighetspolitikk - det skjer en aktiv bevegelse fra første til andre stadium av det Latour (2008) omtaler som politisering. Et personlig problem forstås som noe som kan håndteres sammen med andre likesinnede - i en egeninitiert selvhjelpsgruppe. Når selvhjelpsgruppa flytter ut av det private hjem og til offentlige møteplasser, og samtidig blir tematisert som del av den nasjonale frivillighetspolitikken, har den forandret karakter.

Utover på 1990-tallet utøves selvhjelp på en rekke forskjellige måter av ulike aktivister og selvhjelpsdeltakere, både i form av aktivitetsgrupper og samtalegrupper og innholdsmessig gjennom mentale, somatiske og sosiale utfordringer som det enkelte menneske sliter med. Forskere og en utdanningsinstitusjon, med støtte fra myndighetene, etablerer et Studiesenter som koordinerer, kartlegger og forsker på virksomheten. En rekke forskjellige selvhjelpsaktivister deltar ved Studiesenteret, i ulike 
nettverk og seminarvirksomhet, dette tiåret. Det er mange selvhjelpsaktører på banen og en bred forståelse og praktisering av selvhjelpsarbeid. Selvhjelpsaktivistene opplevde likevel ikke at de hadde definisjonsmakt, og betraktet Studiesenteret som myndighetenes organ.

Fra midten av 1990-årene beveger selvhjelpssaken seg fra å være definert som frivillig arbeid til å få en tettere kobling til psykisk helsearbeid. Selvhjelp politiseres ytterligere ved at saken integreres som en del av myndighetenes opptrappingsplan for psykisk helse. Samtidig er det bred deltakelse fra brukerorganisasjonene i tillegg til selvhjelpsorganisasjonene. Aktivistene arbeider sammen for å få myndighetene til å fremme brukerinnflytelse og brukermedvirkning, og dermed også mer makt til aktivister og brukere innenfor psykisk helsearbeid. Et brukerstyrt organ, Nasjonalt egenkraftsenter, etableres som et toårig prosjekt. I dette arbeidet deltar ikke selvhjelpsaktører som er opptatt av sorgarbeid, somatiske helseproblemer eller sosiale problemstillinger, mens representasjonene fra aktører som arbeider med psykisk helse, er bred.

Den omfattende deltakelsen fra brukerorganisasjonene fører til at selvhjelp praktiseres og defineres relativt åpent. Det etableres ikke et tydelig skille mellom selvhjelpsarbeid og andre former for bruker-initiert hjelp, som for eksempel likepersonsarbeid. Selvhjelpssaken befinner seg nå nærmere stadium tre i Latours typologi. Myndighetene er på banen, men aktiviststyrte institusjoner blir ikke etablert.

I årene fra 2004-2006 endrer dette bildet seg radikalt. Helsemyndighetene vedtar Nasjonal plan for selvhjelpsarbeid og etablerer et nasjonalt kompetansesenter for selvhjelp. Norsk selvhjelpsforum får i mandat å lede det nye senterets arbeid. En ny, revidert nasjonal plan publiseres i 2014. En sentral forskjell fra tidligere er at verken det brede selvhjelpsnettverket fra midten av 1990-tallet eller det omfattende brukernettverket fra psykisk helsearbeid er representert i styring og planlegging av den nasjonale satsingen på selvhjelp i dag. Selvhjelpssaken, ti år etter den første nasjonale planen, er et politisk samarbeidsprosjekt med sentrale helsemyndigheter (Latour 2007, 2008).

De siste tretti årene har vært en periode med mange endringer i forhold til hvem som representerer selvhjelpssaken i offentlige fora. Det 
første tiåret var det et bredt antall sivile aktører. I den neste perioden er det kun selvhjelpsaktøren Angstringen som er med fra første fase og som etter hvert erstattes av Norsk selvhjelpsforum. I tillegg kommer det nye deltakere fra brukerorganisasjonene innen psykisk helsearbeid. Det er med andre ord bare en delvis kontinuitet i hvilken type selvhjelpsaktivister som er med på å definere saken på overordnet, nasjonalt nivå. Det siste tiåret er det kun én aktør, Norsk selvhjelpsforum, som samarbeider med myndighetene om revidering av den nasjonale planen og drift av det nasjonale kompetansesenteret, Selvhjelp Norge. Det tidligere mangfoldet av selvhjelpsaktivister og brukerorganisasjoner er ikke lenger representert i ledende organer i dagens selvhjelpsvirksomhet.

Kan den skiftende politiske legitimeringen av selvhjelpssaken ha hatt betydning for hvordan selvhjelp er blitt definert og selvhjelpsgruppa avgrenset? I den første perioden ble selvhjelp praktisert bredt blant aktivister, frivillige og det sosialfaglig orienterte Studiesenteret. Selvhjelp som metode favnet både aktivitetsgrupper og samtalegrupper samt tematikk fra somatiske og psykiske helseutfordringer i tillegg til sosiale helseutfordringer. Denne brede praksisen snevres inn i neste periode da selvhjelpsaken knyttes tettere til den nasjonale satsingen innen psykisk helsearbeid. I de siste 10-15 årene oversettes selvhjelpssaken til folkehelsearbeid, samtidig skjer det både en avgrensning og en utvidelse av selvhjelpsforståelsen. Selvhjelp utvides til å innbefatte forebygging og håndtering av alle typer livsutfordringer. Selvhjelp Norge etablerer, ved siden av problemspesifikke grupper, en ny type selvhjelpsgrupper som ikke tar utgangspunkt i en type problem, et symptom eller en diagnose. Samtidig avgrenses selvhjelpsgruppa, både fra den brede praksisen ved Studiesenteret, som blant annet innbefatter grupper orientert mot praktiske aktiviteter og/eller nettverks- og sosialt mobiliseringsarbeid, og fra den brede forståelsen til brukerorganisasjonene som blant annet omfatter likepersonsarbeid.

Den lave representasjonen fra andre selvhjelpsaktivister og brukerorganisasjoner i dagens praksis, viser at selvhjelpssaken er betydelig smalere enn for tretti år siden. Samtidig er helsemyndighetene mer involvert i selvhjelpsvirksomheten enn tidligere. Det som særmerker selvhjelpssaken i dag, er at helsemyndigheter har blitt den primære samarbeidspartneren 
for Norsk selvhjelpsforum og ikke andre aktivister fra selvhjelps- og brukerorganisasjoner.

Denne studien viser hvordan selvhjelpssaken har beveget seg inn i politiske dokumenter og meldinger, for deretter å bli tatt opp på Stortingets talerstol, samtidig utformes det en nasjonal plan for selvhjelp, som vedtas og administreres av nasjonale helsemyndigheter sammen med en ledende selvhjelpsaktør. Politiseringsprosessen har både forenet og splittet selvhjelpsaktivistene. Det er i dag ikke et like bredt nettverk av aktører som samarbeider om selvhjelpvirksomhet som i 1990-årene, og det er heller ikke en like åpen forståelse av hvordan selvhjelp kan praktiseres som rundt 200o-tallet. Selvhjelpsarbeid, og da særlig slik det er definert og utøvet av kompetansesenteret Selvhjelp Norge, er i dag et virkemiddel i en nasjonal plan godkjent av helsemyndighetene. Vi har altså identifisert en historisk prosess der en grasrotbevegelse har maktet å formulere sin aktivitet og gjøre den til et offentlig anliggende med stigende deltakelse fra myndighetene.

\section{Referanser}

Bjørgen, D. (2012). Bakgrunn for brukerstyrte sentra og utvikling av brukermedvirkning i Norge, Vedlegg V. I D. Bjørgen, H. Westerlund, A. Storvold \& N. Vesterdal (Red.), Strategiseminaret 19. og 20. november 2012, KBT - MidtNorge Kompetansesenter for brukererfaring og tjenesteutvikling. Hentet fra http:// www.kbtmidt.no/PDF\%2otil\%2onettsiden/Strategiseminaret.November.2012.pdf

Bjørgen, D. \& Jahn, E. (2001). Rapport fra forprosjekt nasjonalt egenkraftsenter og prosjektbeskrivelse for hovedprosjektet: Nasjonalt Egenkraftsenter Mental Helse.

Borkman, T. (1976). Experiential knowledge: A new concept for the analysis of selfhelp groups. Social Service Review, 5o(3), 445-456. Hentet fra http:// www.jstor. org/stable/30015384

Borkman, T. (1999). Understanding self-help/mutual aid: Experiential learning in the commons. New Brunswick, NJ: Rutgers University Press.

Brinkmann \& Kvale, S. (2015). Det kvalitative forskningsintervju. Oslo: Ad notam Gyldendal.

Brottveit, Å. (2013). Endringsarbeid i selvhjelpsgrupper - perspektiver på deltagelse og samarbeid. Oslo: Norsk institutt for by- og regionforskning, Diakonhjemmets høgskole og Høgskolen i Oslo og Akershus.

Eidheim, F. (2000). Selvhjelp i folkehelsearbeid. En forstudie i Angstringen. Oslo: NIBR. 
Feiring, M. (2013). Politicisation of self-help in Norway. I L. Nicolaou-Smokoviti; H. Sünker, J. Rozanova \& V. Pekka Economou (Red.), Citizenship and social development. Citizen participation and community involvement in social welfare and social policy. Frankfurt am Maim: Peter Lang Publishing Groups

Feiring, M. (2019). Selvhjelpsarbeid - mellom erfaringskunnskap og forskningsbasert kunnskap. I O. P. Askheim, I. M. Lid \& S. Østensjø (Red.), Samproduksjon i forskning. Oslo: Universitetsforlaget.

Freire, P. (1973 [1968]). De undertryktes pøedagogik. København: Christian Ejlers' Forlag.

Giddens, A. (1991). Modernity and self-identity: Self and society in the late modern age. Cambridge: Polity Press.

Hedlund, M. \& Landstad, B. J. (2012). The construction of self-help in Norwegian health policy. International Journal of Self-Help and Self-Care, 6 (1), 65-87.

Helsedepartementet. (2003). Resept for et sunnere Norge: Folkehelsepolitikken. (St.meld. $n$ r. 16 (2002-2003)). Oslo: Helsedepartementet. Hentet fra https://www. regjeringen.no/no/dokumenter/stmeld-nr-16-2002-2003-/id196640/

Helsedirektoratet. (2014). Nasjonal plan for Selvhjelp, IS-2168. Oslo: Helsedirektoratet. Hjemdal, O. K. (1996). Status for selvhjelpsfeltet. I O. Sandvik (Red.), Selvhjelp på norsk 2: Rapport fra selvhjelpsseminaret 26. -28. april 1996. Oslo: Høgskolen i Oslo, Avdeling for økonomi-, kommunal- og sosialfag.

Hjemdal, O. K., Nilsen, S., Riiser, B. \& Seim, S. (1996). Kunsten å løfte seg etter håret! Om selvhjelp i Norge. Oslo: Høgskolen i Oslo.

Hughes, E. C. (1984). The sociological eye: Selected papers. New Brunswick: Transaction Books.

Hunter, S. \& Ritchie, P. (2007). Co-production and personalisation in social care: Changing relationships in the provision of social care. London: Jessica Kingsley Publishers.

Høgsbro, K. (1992). Sociale problemer og selvorganisert selvhjoelp i Danmark. Fredriksberg: Samfundslitteratur.

Høgsbro, K. (2012). Social policy and self-help in Denmark - a Foucauldian perspective. International Journal of Self-Help and Self-Care, 6(1), 43-64.

Karlsson, M. (2002). Själv men inte ensam - om självhjälpsgrupper i Sverige (Akademisk avhandling). Edsbruk: Akademitryck AB.

Karlsson, M. (2006). Självhjälpsgrupper - teori och praktik. Lund: Studentlitteratur

Katz, A. H. \& Bender, E. I. (1976). Self-help groups in Western society: History and prospects. Journal of Applied Behavior Science, 12(3), 265-282.

Kierkegaard, S. (1981). Begrebet angest. København: Gyldendal.

Kuhnle, S. \& Selle, P. (1990). Innledning: Frivillige organisasjoner og den tredje sektor. I S. Kuhnle \& P. Selle (Red.), Frivillig organisert velferd: Alternativ til offentlig? Bergen: Alma Mater. 
Latour, B. (2007). Turning around politics. Innlegg presentert ved Social Studies of Science. Hentet fra: http://www.bruno-latour.fr/sites/default/files/103-DE\%2O VRIES-SSofS-GB.pdf

Latour, B. (2008). Pour un dialogue entre science politique et sciences studies. Revue française de science politique, 85(4), 657-678. https://doi.org/10.3917/rfsp.584.0657

Matzat, J. (1992). Selvhjelpsgrupper som grunnleggende behandlingsformi psykoterapi og sosialt arbeid. I L. Fyrand (Red.), Perspektiver på sosialt nettverk. Oslo: Universitetsforlaget.

Matzat, J. (2007). Public acceptance for support for self-help. How things developed in Germany over the last 30 years. Innlegg presentert ved Nine European Expert Meeting on Self-Help Support, Thinking outside the box, Leuven, Belgium.

NOU 1998:18 (1998). Det er bruk for alle. Styrking av folkehelsearbeidet i kommunene Oslo: Sosial- og helsedepartementet.

NOU 2001:22 (2001). Fra bruker til borger. Oslo: Sosial- og helsedepartementet.

NOU 1992:1 (1992). Trygghet, verdighet, omsorg. Oslo: Sosial- og helsedepartementet.

Prior, L. (2003). Using documents in social research. London: Sage Publications.

Røiseland, A. \& Vabo, S. I. (2008). Governance på norsk. Norsk statsvitenskapelig tidsskrift, 24(1-2), 86-103.

Schubert, M. A. \& Borkman, T. (1991). An organisational typology for self-help groups. American Journal of Community Psychology, 19(5), 769-787.

Silverman, D. (1985). Qualitative methodology and sociology. Aldershot: Gower Publishing Company.

Sosial- og helsedepartementet. (1993). «Lat ikkje graset gro att mellom grannar». Om videreføring av arbeidet med frivillighetssentraler (St.meld. nr. 16 (1993-94)). Oslo. Hentet fra http://www.selvhjelp.no/filestore/Stmeld_16_1993_1994_Om_selvhjelp.pdf

Sosial- og helsedepartementet. (1997). Åpenhet og helhet. Om psykiske lidelser og tjenestetilbudene (St.meld. nr. 25 (1996-97)). Oslo.

Sosial- og helsedirektoratet. (2004). Nasjonal plan for selvhjelp, IS 1212. Oslo: Sosialog helsedirektoratet.

Stortinget. (1998). Om opptrappingsplan for psykisk helse 1999-2006. Endringer i statsbudsjett for 1998, St.prop. nr. 63, 1997-98. Stortinget.

Thuen, F. \& Carlsen, B. (1998). Selvhjelpsgrupper. Tidsskrift for samfunnsforskning, 1(39), 28-48. 


\title{
«Midt i smørøyet» - samarbeid og ambivalens i grenseflater mellom profesjons- og erfaringskunnskap
}

\author{
Nora Gotaas
}

By- og regionforskningsinstituttet NIBR, OsloMet - Storbyuniversitetet

\begin{abstract}
The chapter discusses collaborations and «borderwork» between self-help/ mutual aid activists and professionals by the example of the project Utviklingsprosjekt LINK Vestfold. The project was initiated and run by three patient education resource centres (LMS) in Vestfold county in 2009-2010, financially supported by the Directorate of Health and in close collaboration with the National Competence Centre Self-Help Norway. Essentially, the project was very successful, resulting in a broad and active network of professionals and volunteers and the formation of new self-help groups. The project paved the way for a new district office of the National Competence Centre. At the same time, the collaboration revealed certain tensions and ambiguities on both sides, originating in close similarities as well as important differences regarding the use and practice of experiential knowledge - as opposed to professional knowledge - by actors operating in between and on the fringe of established fields. The project highlights how processes of standardization of the self-help model (by Self-Help Norway) is met by kind of resistance and how self-help as a «boundary object» needs to be kept flexible to adjust to different local contexts. This may be an act of balance in a context where the self-help movement is the weaker part regarding institutional strength, in need of guarding the autonomy of self-help groups.
\end{abstract}

Keywords: self-help/mutual aid, patient education resource centre, boundary work, collaborations, professionals, standardization

\section{Introduksjon}

I dette kapittelet vil jeg ta utgangspunkt i et møte mellom Selvhjelp Norge og ansatte i helsetjenestene. Vi skal se nærmere på et prosjekt

Sitering av dette kapittelet: Gotaas, N. (2019). «Midt i smørøyet» - samarbeid og ambivalens i grenseflater mellom profesjons- og erfaringskunnskap. I Å. Brottveit \& M. Feiring (Red.), Samarbeid om selvhjelp. En antologi om den nye selvhjelpsbevegelsen $i$ Norge (s. 91-113). Oslo: Cappelen Damm Akademisk. https://doi.org/10.23865/ noasp.68.ch 4

Lisens: CC BY 4.0 
som ble gjennomført av lærings- og mestringssentrene i Vestfold i 2009-2010, hvor fagfolk innen helsefeltet satte i gang grupper - til dels i samarbeid med frivillige - og utvidet og etablerte et nettverk som la grunnlag for en fastere infrastruktur for selvhjelpsarbeid i fylket. Denne fortellingen om et fruktbart samarbeidsprosjekt inneholder noen spenningsforhold som vekker nysgjerrighet: Samarbeidsprosessen mellom hovedaktørene går lenge bra, før den gradvis kjølner, for så igjen å ende relativt godt. Underveis oppstår det noen knuter på tråden og former for ambivalens som i varierende grad blir uttalt eller tematisert og derfor ikke er så lett å forklare. Hvorfor skjer dette, og hva er ambivalensen et uttrykk for?

I kontrast til de andre eksemplene i denne boka er det spesielt for Vestfoldprosjektet at prosjektet ble initiert innenfra tjenesteapparatet og at de viktigste entreprenørene var profesjonelle helsearbeidere. Det er ikke unikt at Selvhjelp Norge samarbeider med profesjonsapparatet, tvert imot har senteret en lang tradisjon for å spre informasjon og bidra til at ulike aktører i ulike sektorer kan få i gang grupper og prosjekter rundt om i landet. Dette er ett av senterets hovedoppgaver. Eksempelet illustrerer en på mange måter fruktbar allianse mellom Selvhjelp Norge og aktører innen helsevesenet (Borkman, 1976).

Jeg skal løfte frem noen av «suksessfaktorene» i prosjektet, men først og fremst bruke eksempelet til å belyse enkelte tema som gjelder selvhjelpsarbeidets relasjon til profesjons- og behandlingsapparatet.

Selvhjelp kan bli sett som både et supplement og alternativ til profesjonell hjelp. Spørsmål om vektlegging av autonomi kontra samarbeid overfor profesjonsapparatet har vært et viktig tema opp gjennom selvhjelpsbevegelsens historie, både nasjonalt og internasjonalt (Borkman, 1990). Hvordan kan man best bevare og utvikle selvhjelpsarbeidet i møte og samspill med kunnskapssyn og praksisformer som likner mye og som samtidig er ulike på vesentlige måter? Når jeg her ser på relasjonen mellom Selvhjelp Norge og profesjonene, er det derfor en inngang både til å forstå noen særtrekk ved selvhjelpsarbeid generelt og slik det har blitt utformet av Selvhjelp Norge spesielt.

I analyse av samarbeidsprosesser er det generelt nyttig å se på hvordan aktørene forstår og håndterer grenser seg imellom. I dette tilfellet må 
«grensearbeidet» mellom Selvhjelp Norge og Vestfoldprosjektet «skrives frem», fordi det - så langt jeg kan bedømme - av aktørene selv opplevdes som litt udefinerbart og vanskelig å sette ord på. I denne boka er vi inspirert av teorien om grenseobjekter for å belyse hvordan aktører «forhandler» seg imellom om forståelsen av det felles objektet de samarbeider om, og hvordan ulike aktører kan ha ulike «oversettelser» av hvordan denne forståelsen skal omsettes i praksis (se introduksjonskapittelet). I slike prosesser vil det være et spenningsforhold mellom et behov for standardisering og et behov for fleksibilitet. "Grenseobjektet» man samarbeider om - i dette tilfellet selvhjelpsforståelse og selvhjelpspraksis - må defineres bredt og fleksibelt nok til at ulike samarbeidspartnerne kan identifisere seg med det. Samtidig må det defineres såpass standardisert at det fremstår gjenkjennelig på tvers av kontekster. ${ }^{1}$ Denne typen spenningsforhold mellom standardisering (hva som skal være felles) og fleksibilitet (hva som kan være partikulært) blir aktuelt når grenseobjektet tilpasses og «oversettes» til en lokal kontekst, i dette tilfellet prosjektet i Vestfold. ${ }^{2}$ Ofte vil en aktør ha posisjon som et «centre of authority» som forvalter definisjonsmakt for hvordan grenseobjektet skal forstås, og hvordan grenser mot tilstøtende praksiser skal håndteres. Slik jeg ser det, dreide ambivalensen som kom til uttrykk i relasjonen mellom Selvhjelp Norge og prosjektledelsen i Vestfold seg etter hvert i stor grad om denne typen grenseproblematikk; hvor fleksibelt og hvor standardisert selvhjelpsarbeid kan praktiseres, og hvem som skulle være i posisjon til å definere grensene og hva som faller innenfor og utenfor.

1 Begrepet «grenseobjekt» kan i prinsippet brukes om svært mye, så lenge det betegner et objekt som blir brukt som et felles mål eller middel aktørene imellom. Et kriterium er at dette felles objektet er heterogent på en slik måte at det relaterer seg til - og derfor kan tilpasses og brukes på tvers av - ulike sfærer (domener) (Star \& Griesemer, 1989). Selvhjelpspraksis er godt egnet som grenseobjekt fordi det er en sosial form som henter elementer fra ulike livsverdener; fra dagliglivets uformelle og intime samværsformer, fra sivilsamfunnets organiseringsformer, samt har fellestrekk med gruppeterapeutisk praksis i profesjonssfæren. Det gir et potensial for at objektet kan brukes på både fleksible måter (med rom for tolkninger) og standardiserte (spesialiserte) måter. Teorien kan brukes til å belyse enkelte tema som ellers er lite i fokus, blant annet hvordan aktører med ulike ståsted og med ulike interesser kan skape et felles handlingsrom (shared space) (Giskeødegård, 2016). For mitt formål er det problematiseringen av forholdet mellom fleksibilitet og standardisering som fremstår som spesielt nyttig. Uttrykket «grensearbeid» har jeg hentet fra Giskeødegård.

2 Grenseobjekter vil som oftest være «(...) weakly structured in common use and become strongly structured in individual-site use» (Star, 1988, s. 46). 
Prosjektet i Vestfold illustrerer både nytteverdi og mulige fallgruver i en samarbeidsprosess der det er overlapping mellom ulike typer kunnskap og institusjonene som skal fremme og forvalte denne kunnskapen: Mellom på den ene siden lærings- og mestringssentrene, som har som oppgave å formidle og sidestille profesjons- og erfaringskunnskap, men som arbeider ut fra en profesjonell plattform, og Selvhjelp Norge, som har som hovedoppgave å fremme «bare» erfaringskunnskap. Jeg sammenlikner hovedaktørene langs tre akser: kjennetegn ved det kunnskapssynet de forvalter, hva som karakteriserer dem institusjonelt som type aktører, og hvordan de forstår innholdet i og grensene rundt selvhjelp og selvhielpsarbeid.

Selvhjelpsarbeidet i Vestfold er et eksempel på sosialt entreprenørskap i grenseland mellom stat og sivilsamfunn og mellom profesjons- og erfaringskunnskap. Fremstillingen tar utgangspunkt i de lokale aktørenes møte med selvhjelpsidéen slik den blir formidlet av Selvhjelp Norge. I analysen vil jeg veksle mellom relativt detaljerte etnografiske beskrivelser og institusjonelle rammer.

\section{Metode}

Hoveddelen av det empiriske materialet er hentet fra et feltarbeid hvor jeg fulgte utviklingen av prosjekt LINK Vestfold samt fra en kartleggingsundersøkelse jeg gjennomførte ved avslutning av prosjektet (Gotaas, 2012). Her intervjuet jeg totalt 29 personer som var deltakere i, eller ledere av, et stort selvhjelpsnettverk i Vestfold. De fleste ble intervjuet per telefon, mens lederne i nettverket ble intervjuet ansikt til ansikt. Hovedtema var erfaringer knyttet til etablering og igangsetting av selvhjelpsgrupper i fylket. Prosjekt LINK Vestfold hadde som en av sine målsettinger å bidra til at det ble satt i gang grupper, og kartleggingen ga derfor også en del informasjon om gjennomføringen av prosjektet.

Kontakt med styringsgruppa i nettverket ble opprettet gjennom Selvhjelp Norge. Jeg fulgte prosjektet periodevis gjennom ett og et halvt år ved å være til stede på møter i styringsgruppa og i nettverket, på møter mellom styringsgruppa og Selvhjelp Norge, samt ved å ha uformelle samtaler og gjøre intervju med prosjektledelsen om prosjektet som helhet. 
I tillegg var jeg til stede på konferanser og samlinger arrangert av Selvhjelp Norge hvor representanter for Vestfoldprosjektet deltok.

Jeg har ikke intervjuet de sentrale selvhjelpsaktørene i Selvhjelp Norge spesielt om denne samhandlingsrelasjonen. En grunn til det er at jeg i Vestfold-casen opprinnelig hadde fokus på prosessene omkring etablering av grupper og ga mindre oppmerksomhet til selve samhandlingsrelasjonen med Selvhjelp Norge. I næranalysen av data så jeg at denne relasjonen inneholdt tema som fortjente en bredere diskusjon. Som nevnt har jeg imidlertid vært observatør på flere møter mellom Selvhjelp Norge og Vestfoldprosjektet og gjennomgått aktuelle dokumenter og skriftlig materiale fra begge parter. Viktige data har jeg også hentet fra intervju med representanter fra Selvhjelp Norge om senterets samlede virksomhet, fra feltarbeidet hvor vi fulgte senterets generelle informasjons- og formidlingsarbeid, samt skriftlig materiale omkring Selvhjelp Norges historikk. Samlet sett belyses relasjonen mellom partene i større grad ut fra LMS-Vestfold sitt ståsted enn fra Selvhjelp Norges, samtidig mener jeg datamaterialet er bredt nok til å beskrive dynamikken mellom aktørene.

Alle aktører var velvillige til min tilstedeværelse som observatør. Det kan knyttes til flere forhold, blant annet at det å bli gjenstand for forskningsinteresse gir en viss legitimitet, i dette tilfellet til instanser som befinner seg på siden av mer etablerte og prestisjefylte virksomheter. Det var også viktig at jeg kunne bruke tid på gradvis å nærme meg feltet og bygge tillit, og inngå noe i samhandlingssituasjoner før og etter møter. Jeg skrev feltnotater underveis på møtene, til dels også fra uformelle samtaler, som deretter ble kodet. Det samme gjelder intervjunotater.

Både LMS Vestfold og Selvhjelp Norge har gitt kommentarer til en tidligere versjon av dette kapittelet. Sluttproduktet er jeg selv fullt ut ansvarlig for.

\section{Casebeskrivelse - hvordan artet prosessen seg?}

Før vi går inn i en bredere diskusjon av samarbeidsrelasjonen mellom Selvhjelp Norge og aktørene i Vestfold, vil jeg gi en beskrivelse av hvordan Prosjekt LINK Vestfold kom i stand og en oversikt over utviklingen i prosjektet. 


\section{Fra prosjekt til distriktskontor - Prosjekt LINK Vestfold}

I 2007 var lederen av Selvhjelp Norge en av foredragsholderne på en stor konferanse arrangert av daværende Helse Sør-Øst for lærings- og mestringssentrene i regionen.

Folk som var til stede, forteller at innlegget ble holdt med glød og karisma. Det gjorde inntrykk på forsamlingen å høre om grunntankene i selvhjelpsarbeidet. Innlegget vekket spesielt interesse hos en gruppe ansatte fra lærings- og mestringssentrene i Vestfold. De hadde allerede noe kjennskap til selvhjelpsarbeid, men presentasjonen førte til at de engasjerte seg for å få i gang grupper lokalt. Alle meldte seg etter hvert på igangsetterkurs hos Selvhjelp Norge og tok også initiativ til å organisere et nettverk av folk som hadde erfaring fra eller var interessert $\mathrm{i}$ selvhjelpsarbeid: «Nettverk for igangsettere i Vestfold». Nettverket favnet både fagfolk på ulike områder og frivillige organisasjoner. De LMS-ansatte i fylket, som var samlet i et permanent samarbeidsforum, LMSforum Vestfold, tok kontakt med Selvhjelp Norge og sa de ønsket å sette i gang med mer organisert selvhjelpsarbeid. Kort fortalt endte det med at de søkte - og fikk - prosjektpenger fra Helsedirektoratet for en periode fra juni 2009 til utgangen av 2010. Prosjektet kan betegnes som vellykket på flere måter, både ved at det ble satt i gang et relativt stort antall grupper og ved at det ble høstet erfaringer og bygget nettverk.

En av de viktigste grunnene til at prosjektet genererte mye aktivitet og fikk stor gjennomslagskraft, var at styringsgruppa i prosjektet - allerede før prosjektstart - utgjorde en slagkraftig enhet på tvers av felt og sektorer. Styringsgruppa bestod av medlemmene i LMS-forum Vestfold, som kjente hverandre godt. Forumet hadde erfaring fra å sette i gang ulike utviklingsprosjekter og hadde opparbeidet en relativt solid posisjon opp imot både fagmiljø, tjenesteapparat og pasientorganisasjoner. ${ }^{3}$ I prosjektet

3 I Vestfold hadde deler av LMS-arbeidet en unik form sett i forhold til resten av landet, ettersom fylket var det eneste med to helseforetak, og LMS-organiseringen fulgte denne inndelingen, slik at det var et LMS ved Sykehuset i Vestfold (SIV) HF og et LMS ved Psykiatrien i Vestfold (PIV) HF. I tillegg huset fylket landets eneste kommunale LMS, plassert i Sandefjord. De tre LMSene hadde etablert en fellesarena gjennom samarbeidsforumet. Det innebærer at LMS-forumet i Vestfold, før de møtte Selvhjelp Norge, i enda større grad enn «vanlige» LMS-sentra hadde utviklet en posisjon orientert mot nettverks- og alliansebygging og en rolle som kunnskaps- 
utviklet de denne posisjonen videre til en node i et bredt selvhjelpsnettverk (Gotaas, 2012). De sørget for å bygge strategiske allianser både «oppover, bortover og nedover», det vil si til administrativ ledelse i eget foretak, til fagpersoner i helsetjenestene, ansatte i kommunene, til frivillige organisasjoner og til brukere av dagsentra, LMS-kurs, frivilligsentraler og andre.

\section{Samarbeid med svingninger}

Både før, under og etter selve prosjektperioden var relasjonen mellom lærings- og mestringssentrene og Selvhjelp Norge helt sentral. Det gjaldt både på et formelt plan, ved at Selvhjelp Norge var faglige rådgivere overfor Helsedirektoratet og hadde stor innvirkning på fordelingen av midler gjennom «Tilskuddsordningen for selvhjelpsprosjekter». ${ }^{4}$ Det var også et vilkår for finansiering at prosjektansvarlige skulle samarbeide med Selvhjelp Norge både i utforming og gjennomføring av prosjektene og basere seg på den begrepsmessige forståelsen av selvhjelpsarbeid som Selvhjelp Norge legger til grunn. Sett utenfra gikk samarbeidsprosessen i store trekk bra. Prosjektet hadde stor nytte av Selvhjelp Norge før og under oppstartsfasen med hjelp til utforming av søknad og råd om hvordan komme i gang. Det samme gjaldt underveis i prosjektet. De sentrale selvhjelpsaktørene stilte seg til disposisjon, både ved å delta på enkelte møter i nettverket, arbeidsgruppa og styringsgruppa for prosjektet og være tilgjengelige over telefon fra hovedkontoret. Selvhjelp Norge bidro også med opplærings- og informasjonsarbeid i form av foredrag og igangsetterkurs, en felles erfaringssamling for alle prosjektene under tilskuddsordningen, i tillegg til skriftlig informasjonsmateriell. Ved siden av å yte alle disse formene for konkret bistand var Selvhjelp Norge svært viktig som en garantist for selvhjelpsarbeidets berettigelse, spesielt overfor de helsefaglige miljøene. Gjennom statlig finansiering og forankring

formidler/oversetter i grenseflater mellom ulike sektorer, fagfelt, offentlige tjenester og frivillig arbeid.

4 Tilskuddsordningen var ett av de viktigste virkemidlene i Nasjonal plan for selvhjelp fra 2004. De to andre hovedvirkemidlene var etablering av senteret Knutepunktet og en tilskuddsordning for forskning. Tilskuddsordningen virket fra og med $2006 \mathrm{og}$ ble i hovedsak avsluttet ved utgangen av 2009. Midler ble da i stedet rettet inn mot etablering av i alt 7 distriktskontorer. Det siste kom på plass i 2012. 
av selvhjelpsarbeid i sentrale politikkdokumenter hadde senteret et faglig godkjenningsstempel fra Helsedirektoratet. LMS-forumet fremholdt at det var viktig - og vanskeligst - å etablere legitimitet for selvhjelpsarbeid inn mot fagmiljøene.

Et stykke ut i prosjektperioden ble det imidlertid mindre kontakt mellom Selvhjelp Norge og prosjektgruppa, og det var tydelig at samarbeidsrelasjonen kjølnet. Det konkrete omdreiningspunktet gjaldt spørsmålet om etableringen av et nytt distriktskontor, som Vestfold var blitt lovet at skulle komme høsten 2010.5 Opprettelsen ble utsatt og kom på plass først ett år senere.

Sett fra de involverte partenes side endte historien godt og det har ikke vært særskilte problemer i etterkant. Fortellingen peker likevel ut over seg selv ved å tydeliggjøre spenningsforhold mellom to kunnskapsforståelser som dels overlapper, men samtidig er forankret i ulike sosiale verdener.

\section{Kunnskap og "grenseinstitusjoner»}

Både lærings- og mestringssentrene og Selvhjelp Norge er relativt unge virksomheter som har vokst frem gjennom grasrotaktiviteter i det som kalles frivillig sektor og fått form av offentlige institusjoner. ${ }^{6}$ Begge legger til rette for fremvekst og formidling av kunnskap «nedenifra», fra folks egne erfaringer, men med ulik vekt og form.

Et kjennetegn ved selvhjelpsgrupper er at deltakerne kommer til gruppa med sine personlige opplevelser og erfaringer. Gjennom å utveksle fortellinger og reflektere omkring dem i et fellesskap av likesinnede gis

5 Da Selvhjelp Norge og Helsedirektoratet underveis i prosjektperioden utviklet strategien om etablering av distriktskontorer og avsluttet tilskuddsordningen, endret dette prosjektets opprinnelige målsetting om å etablere en form for fylkessenter. Dermed var det heller ikke aktuelt for Vestfoldprosjektet å søke om ytterligere prosjektmidler, slik det var lagt opp til i prosjektsøknaden. Prosjektet fikk imidlertid overført prosjektmidler til 2010.

6 Alm Andreassen fremhever hvordan innovasjonsprosesser på velferdsfeltet i Norge ofte kjennetegnes av at det defineres et behov, en form for mangel, som innebærer en kritikk av det bestående, enten åpent eller implisitt. I prosessen etableres det nye nettverk sammensatt av aktører med ulike typer kunnskap. De tar ofte form av forsøksvirksomhet før de eventuelt går over i mer permanent organisering. Da etableres de imidlertid som enheter på siden av «linja» og etablerte styringsstrukturer, det vil si i ytterkanten av sosiale felt. Begge type sentre er resultat av denne typen innovasjonsprosesser (Alm Andreassen, 2011). 
opplevelsene form, sammenheng og mening og tar form av erfaringskunnskap (Borkman, 1976; 1990, s. 16). En slik omforming kan skje individuelt eller sammen med andre, selvhjelpsgrupper er innrettet mot at erfaringer og forståelsen av dem kan gis en ny form og retning gjennom en felles, refleksiv prosess.? Dette kan innebære nye betraktninger omkring ens personlige situasjon og historie og gi grunnlag for en reorientering av selvforståelse og handlemåter.

Det viktige for oss her er at selvhjelpsgrupper er basert på og produserer erfaringskunnskap eller erfaringsbasert kunnskap (Borkman, 1976, 1990; Talseth, Godager \& Bruland, 2004). Termene brukes mye i helseog sosialfeltet og innenfor pedagogikken som en kontrast til fagkunnskap eller profesjonskunnskap. Grovt sagt kan vi si at fagkunnskap er en type kunnskap profesjonene erverver gjennom formell utdanning, en kunnskapsform med høy grad av objektivering og standardisering. Profesjonskunnskapen er kvalitetssikret og beskyttet gjennom formaliserte rutiner og er slik en eksklusiv form for kunnskap. Mens erfaringsbasert kunnskap eller erfaringskunnskap, slik jeg bruker det her, først og fremst er kunnskap generert gjennom individer eller kollektivers egenerfaring utenfor profesjonenes eller ekspertisenes domene. ${ }^{8}$

Erfaringskunnskap og fagkunnskap er ulike kunnskapsformer som i stor grad formes og forvaltes på ulike måter og av ulike typer aktører og institusjoner. I praksis vil begge hovedtyper ofte ha elementer fra den andre og vi vil finne mange grader av overlapping og blandingsforhold; former for hybrid kunnskap (Ramsdal, Hansen, Helgesen \& Feiring, 2008). For eksempel vil profesjonene ta i bruk erfaringer fra privatlivet i yrkesutøvelsen og også tilegne seg erfaringskunnskap gjennom arbeidet. ${ }^{9}$

7 Organisasjonspsykologen David Kolb definerer læring som «(...) den proces hvorved erfaring (experience) omdannes til erkjennelse» (Kolb, 200o). All tilegning av kunnskap forutsetter bruk av erfaring. Av dette kan vi slutte at ettersom kunnskap er noe som kan deles og overføres, kan erfaring, i bearbeidet form, også til en viss grad deles. Kolb har vært en av inspiratorene for Borkmans syn på læringsprosesser (Borkman, 1999, s. 41, 143).

8 Borkman opererer riktignok også med et skille mellom erfaringsbasert kunnskap og lekkunnskap, der den siste kunnskapsformen ikke bygger på personlige erfaringer, men på akkumulert erfaringskunnskap hos pårørende og ikke-profesjonelle støttespillere i det sosiale nettverket (Borkman, 1999, s. 21-22). Jeg betrakter ikke dette analytiske skillet som nødvendig for drøftingene i dette kapittelet.

9 Ofte brukes begrepet «praksiskunnskap» eller "praksisbasert erfaringskunnskap» om den erfarte kunnskapen man erverver gjennom yrkesutøvelse (eller trenger å lære i utdanningen), 
Motsatt er mye erfaringskunnskap og folks fortolkning av eget liv formet av profesjonskunnskap, det tilflyter oss for eksempel terapeutiske forståelsesmåter gjennom media.

Som vi legger vekt på i innledningskapittelet, kan fremveksten av «den nye selvhjelpsbevegelsen» på 1970- og 80-tallet sees som uttrykk for en generell nyorientering i de vestlige velferdsstatene og i helsetjenestene. Denne inkluderer en oppvurdering av erfaringskunnskap og et behov for utveksling mellom kunnskapsformer. Et vesentlig trekk var erkjennelsen av at vitenskapelig kunnskap og ekspertkunnskap er utilstrekkelig for å definere og håndtere folks helse og sosiale problemer. Profesjonene så at de trengte en viss innlemming av erfaringskunnskap i profesjonskunnskapen og at det var nødvendig å omforme relasjonen hjelper-klient slik at klienten i større grad ble myndiggjort (Høgsbro, 2012; Karlsson, 1997; Katz \& Bender, 1976). Motsatt vei lånte selvhjelpsideologien til dels idéer fra profesjonskunnskapen ved å ta i bruk elementer fra terapeutiske praksiser som gruppeterapi og nettverkstenking (Gotaas, 2012). Med andre ord tok både profesjonskunnskapen og erfaringskunnskapen opp i seg elementer fra andre kunnskapskilder og er slik eksempler på fremvekst av blandingsforhold.

Etableringen av Selvhjelp Norge og lærings- og mestringssentrene er på hvert sitt vis uttrykk for oppvurdering og anerkjennelse av erfaringskunnskap på helse- og sosialfeltet i Norge. Vi skal nå se nærmere på hvordan de to institusjonene er utformet for å forvalte slik kunnskap «nedenifra».

\section{Institusjonelle rammer}

Det første senteret for pasientopplæring, «Mestringssenteret» (Senter for pasientopplæring), ble etablert som et pilotprosjekt ved Aker sykehus i 1997 med midler fra Helsedirektoratet. Tre år senere ble det institusjonalisert som en del av spesialisthelsetjenesten. I dag er lærings- og mestringstjenester en lovpålagt tjeneste i spesialisthelsetjenesten, med stor lokal og regional variasjon i hvordan tjenesten organiseres.

i kontrast til «teoretisk kunnskap» (Gjøsæter \& Kyvik, 2015). Grimen fremhever at «(...) det ikke finnes noe klart skille mellom kunnskapsformer, men at det dreier seg om et kontinuum» (Grimen, 2008, s. 71). 
Knutepunktet Selvhjelp Norge ble opprettet som et toårig prosjekt også med midler fra Helsedirektoratet - i 2006 - og fikk en mer permanent organisering etter at det var blitt eksternt evaluert og fătt et «godkjenningsstempel» i 2008. To år senere skiftet senteret navn fra «Knutepunktet» til «Kompetansesenter».

Det er et viktig poeng at Selvhjelp Norge har form av først et prosjekt og så et kompetansesenter og ikke har som utgangspunkt å være en medlemsbasert bruker- eller interesseorganisasjon. Selvhjelp Norge konsentrerer seg om å fremme en mer rendyrket erfaringskunnskap enn bruker- og interesseorganisasjonene ved at erfaringskunnskap ikke blandes med rettighetsbasert eller interessepolitisk arbeid. Man kan tenke at denne rendyrkingen bidrar til kompetanseoppbyggingen og formidlingsvirksomheten til Selvhjelp Norge i større grad får form av en objektivering av erfaringskunnskapen som erverves gjennom selvhjelpsgruppene.

Både LMS-ene og Selvhjelp Norge befinner seg i usikre posisjoner med usikker finansiering, i ytterkanten og imellom etablerte felt. LMS-ene er imidlertid en type virksomhet som er tettere integrert i staten enn Selvhjelp Norge, gjennom å utføre lovpålagte tjenester, hovedsakelig innenfor spesialisthelsetjenesten.

Selvhjelp Norge er et nasjonalt kompetansesenter med tilhørende distriktskontorer, og er finansiert av Helsedirektoratet. Partnerskapet mellom stat og sivilsamfunnsaktører strekker seg til og med distriktskontorene, og ikke lenger. Det er et viktig prinsipp at alt lokalt arbeid skal gjøres av lokale aktører. Disse kan komme fra hele spekteret av profesjons- og tjenesteapparatet, helse- og omsorgstjenestene, frivillige organisasjoner, frivilligsentraler, frisklivssentraler, enkeltpersoner m.m. Selvhjelp Norge er nøye med å poengtere at de ikke skal drive det konkrete og lokale selvhjelpsarbeidet.

Selvhjelp Norge og LMS-ene representerer ulik grad av og ulik form for institusjonalisering av rammer for å fremme erfaringskunnskap: Selvhjelp Norge har som hovedoppgave å fremme erfaringskunnskap knyttet til en bestemt type sosial praksis, LMS har som hovedoppgave å sidestille erfarings- og fagkunnskap på en rekke ulike diagnose-områder. ${ }^{10}$ Selv om

10 I Norge er det tradisjon for at ulike velferdspolitiske initiativ eller bevegelser på helse- og omsorgsfeltet oppstår lokalt og inkorporeres i offentlige strukturer. Norden generelt har vært kjennetegnet av en sterk «statsvennlighet» hvor det offentlige, i form av stat eller kommune, i stor 
LMS-ene sidestiller de to kunnskapsformene i utforming av pasienttilbud, settes erfaringskunnskapen inn i en profesjonell ramme der det er fagkunnskapen som i stor grad legitimerer bruken av erfaringskunnskap (og i mindre grad omvendt). Mens for Selvhjelp Norge er det helt avgjørende å sikre erfaringskunnskapen og selvhjelpgruppenes autonomi. Som vi skal se senere, kan dette være med på å forklare hvorfor Selvhjelp Norge i en periode ble mer tilbakeholdne overfor Vestfoldprosjektet.

Både Selvhjelp Norge og lærings- og mestringssentrene er institusjoner som har medierende roller ved å formidle kunnskap på tvers av fagfelt og det vi kan kalle livs- og problemområder.

Et vesentlig poeng er at Selvhjelp Norge og LMS-ene ikke bare har en rolle som formidler eller oversetter mellom ulike felt, de tar opp i seg og består selv av elementer fra flere ulike sosiale verdener. De har en sammensatt kjerne. De er organisasjoner som er avhengig av kontinuerlig nettverkssamarbeid og tilpasning for å bevare og bygge denne kjernen. I forlengelsen av Star og Griesemers teori om grenseobjekter betegner Guston slike organisasjoner som grenseorganisasjoner (boundary organizations). Disse trekkene gir både Selvhjelp Norge og LMS-forumet en generell interesse av å utvikle samarbeid med mange ulike typer aktører. I Prosjekt LINK Vestfold kunne begge dra nytte av og komplementere hverandres roller og kunnskapsposisjoner.

\section{Overlappende kunnskapsforståelse - ulik mengde verktøy}

Det er lett å peke på overordnede likhetstrekk mellom Selvhjelp Norge og lærings- og mestringssentrene når det gjelder kunnskapsforståelse og det vi kan kalle virksomheten ideologi. Begge målbærer en

grad ikke sees som en trussel mot frivillighet og autonomi, men tvert imot som en garantist for den (USA er den mest åpenbare motsatsen, men det samme gjelder i stor grad deler av kontinental-Europa (Trägårdh, 1997). Det vil si i hvilken grad aktører i det frivillige som fremmer og forvalter slik kunnskap, vil se statlige strukturer og grader av institusjonalisering av erfaringskunnskap som en trussel mot erfaringskunnskapens autonomi. Eller tvert imot som nødvendige rammer for å sikre denne autonomien (jf. ulike posisjoner omkring forholdet mellom statlige strukturer og frivillig arbeid (Alm Andreassen, 2006; Repstad, 1998). Det kan føyes til at allianseforholdet mellom stat og frivillighet er i endring, for eksempel har man i Sverige de siste tiårene sett en bred privatisering av offentlige tjenester. 
«empowerment»-ideologi (Askheim, 2007), hvor formålet er å øke enkeltpersoner evne til å mestre og håndtere problemområder i tilværelsen. Begge fremmer sosiale praksiser basert på et loringsperspektiv og har utviklet gruppesettinger som viktigste arena for læring. «Selvhjelpen er midt i smørøyet for LMS-arbeid», som én av initiativtakerne i Vestfold uttrykte det. De LMS-ansatte hadde erfart at det i etterkant av læringsog mestringskurs var behov for «noe mer» hos en del av deltakerne. Det blir også fremhevet at man innen psykiatrien så at mange personer kunne ha nytte av hjelp på et lavere nivå, før problemene utviklet seg til å bli et behandlingsbehov hos spesialisthelsetjenesten.

Selvhjelp Norge, på sin side, hadde stor interesse av å få LMS-ene og helsevesenet generelt til å ta i bruk selvhjelp. LMS-enes kunnskapssyn og gruppepraksis ga gjenklang i Selvhjelp Norges syn på betydningen av folks egenerfaring og potensial for selv å ta tak i sine livsproblemer.

Sentrenes forhistorie, hvor de selv er resultat av prøveprosjekter, gir føringer for en praksis hvor de er åpne for å prøve ut nye fremgangsmåter. Slik kan de også tilby komplementære ressurser: Selvhjelp Norge tilbyr en metodikk som støtter oppunder LMS-arbeidets virksomhetsideologi, LMS-forumet tilbyr strukturer og miljø som kan spre kunnskap om og ta i bruk denne sosiale praksisen og slik bidra til å realisere Selvhjelp Norges ambisiøse målsetting om å nå frem til hele befolkningen.

Her er vi ved et kjernepunkt. En vesentlig forskjell mellom LMS og Selvhjelp Norge er graden av variasjon i virksomhetenes metodiske verktøykasse. LMS-enes hovedoppgave, pasient- og pårørendeopplæring, er en vid og sammensatt oppgave og til dette kan de ta i bruk et relativt bredt repertoar av metodiske verktøy. Selvhjelp Norges hovedoppgave er å formidle ett begrep og én forståelse, selvhjelp, og ett verktøy, én «metode» i form av selvorganiserte selvhjelpsgrupper.

Når LMS kombinerer profesjons- og erfaringskunnskap, kan dette gjøres på en rekke ulike måter, så lenge de følger det som kalles «standard metode», som er en overordnet prosedyre for å sikre at fagfolk og legfolk medvirker på lik linje i utforming av anvendte metoder og gjennomføring av tilbudene. Fremgangsmåten skal sikre at erfaringskunnskapen og fagkunnskapen likestilles. Selvhjelp Norge, på sin side, fremmer erfaringskunnskap knyttet til én bestemt type metode, og åpner i mindre grad for at de lokale aktørene 
og samarbeidspartene (for eksempel LMS Vestfold) kan få medvirke til utformingen av den. Som nevnt i innledningen har grenseobjekter og grenseorganisasjoner en innebygget spenning mellom standardiseringsbehov og fleksibilitet for lokale tilpasninger. Selvhjelp Norges strategi med vekt på standardisering vil ifølge denne teorien ha «omkostninger» fordi den vil ta for lett på de samarbeidende aktørenes tilpasningsbehov.

For Selvhjelp Norge er metoden sterkt definerende for hva selvhjelp er og skal være. ${ }^{11}$ LMS-ene ser ut til å dele mye av Selvhjelp Norges forståelse, men de har samtidig en mer eklektisk og pragmatisk tilnærming til hva de har i verktøykassa, og er ikke så opptatt av metodisk «renhet». Selvhjelp Norge er bekymret for at LMS-ene skal komme til å praktisere selvhjelpsarbeid på en måte hvor det enten kan bli tatt over og/eller utvannet av de profesjonelle. Mens for LMS-ene er det antakelig vanskelig å se at de som fagfolk kan oppfattes som utfordrere, ettersom de er såpass pragmatiske i tilnærmingen og er vant med en rolle der de må jobbe for å få anerkjennelse fra mektigere fagmiljøer. Disse forholdene var med på å gi en viss ambivalens i relasjonen mellom Selvhjelp Norge og LMS-forumet. ${ }^{12}$

\section{Tilbake til prosessen}

\section{Hva slags knuter på tråden?}

I perioden da det var relativt «stille» i selve samarbeidsrelasjonen, var det på samme tid desto mer tematisering av denne tausheten internt hos

11 Selvhjelp Norge bruker ikke selv begrepet «metode», men formulerer retningslinjer for gruppearbeid som «rammer og prinsipper». Jeg vil understreke at når Selvhjelp Norge benytter én metode, står det ikke i motsetning til det faktum at senteret, som en del av sitt generelle utviklingsarbeid, har prøvd ut en rekke ulike tilnærminger for å bygge nettverk og få i gang selvhjelpsgrupper rundt om i landet. De ulike casestudiene i denne boka viser nettopp en stor grad av fleksibilitet når det gjelder hvilke allianser selvhjelpsarbeid kan inngå i, - og hvordan.

12 På et overordnet plan er spenningsforholdene i relasjonen også uttrykk for det nevnte temaet i selvhjelpens historie internasjonalt som gjelder grensedragning mellom behandling og selvhjelp. I dette tilfellet skjer det ved at selvhjelpen ikke knyttes til det problem- eller diagnosespesifikke. Helt fra oppstarten av prosjektet var Selvhjelp Norge nøye med å poengtere viktigheten av at nettverket ikke måtte bli for tett knyttet til behandlingsapparatet og at man måtte løfte prosjektet utover det sykdomsrelaterte og knytte det til det bredere folkehelsearbeidet. På et felles møte viste LMS-forumet til at «Men vi jobber også forebyggende og på tvers av diagnoser». Selvhjelp Norge svarte: «Ja, men det er fremdeles diagnosene som er utgangspunktet for at folk kommer til LMS». 
Vestfold-aktørene. For dem var reduksjon i kontakt og tilbakemeldinger en kilde til frustrasjon.

Kort presentert var utviklingen i perioden slik: Noen måneder etter at Vestfoldprosjektet kom i gang, lanserte Selvhjelp Norge og Helsedirektoratet strategien om oppbygging av regionale distriktskontorer. ${ }^{13}$ Tidlig på året fikk Vestfold-aktørene informasjon om strategien og at de stod øverst på lista når det gjaldt å få et distriktskontor på beina. Samtidig fremholdt Selvhjelp Norge at finansieringen på sikt ikke var sikker, fordi man var avhengig av statlige midler året etter. I februar var LMS-forumet med på en nasjonal konferanse Selvhjelp Norge arrangerte på Gardermoen, hvor denne strukturen ble presentert. De ansatte reagerte på at prosjektet i Vestfold ikke ble nevnt, mens andre distrikter, hvor prosessen så ut til å ha kommet kortere, ble løftet frem. Dette ble et sentralt tema på et møte i styringsgruppa, hvor man bestemte seg for å gjøre en henvendelse til Selvhjelp Norge med invitasjon til et møte før sommeren.

På våren ble det avholdt et møte hvor Selvhjelp Norge kunne fortelle at de nå nettopp hadde fått vite at det kom midler over statsbudsjettet slik at et distriktskontor kunne komme på plass i september. De presiserte igjen at drift året etter var avhengig av midler over statsbudsjettet. Vestfold-aktørene ble bedt om å høre med folk som kunne være aktuelle lederkandidater. Deretter ble det stille. Tidlig på høsten signaliserte aktørene overfor Selvhjelp Norge at prosjektperioden gikk mot slutten og at de var i ferd med å miste pågangsmotet.

I oktober hadde styringsgruppa et møte hvor de uttrykker skuffelse og frustrasjon. I midten av november kommer det ny beskjed fra Selvhjelp Norge om at det nå kommer midler til distriktskontoret. Koordinatoren er påholden med å informere nettverket og sier i møte med styringsgruppa at: «Jeg tror det ikke før jeg får se det». Selvhjelp Norge ber om et møte tidlig i januar 2011. Her blir det presentert konkrete planer for et nytt kontor. Selvhjelp Norge driver selv prosessen videre, i august tiltrer leder av distriktskontoret, og i november er det offisiell åpning i Tønsberg.

13 Som nevnt, skulle tilskuddsordningen avvikles og midler i stedet kanaliseres inn mot etablering av distriktskontorene. 
Det er viktig å presisere at Vestfold-entreprenørene holdt deler av selvhjelpsarbeidet i gang for egen maskin i trekvart år etter at prosjektet formelt var over og før distriktskontoret var operativt. Forumet fortsatte med å koordinere henvendelsene og sette i gang grupper. Dette kunne de gjøre fordi selvhjelpsarbeidet var integrert del av LMS-enes infrastruktur; de kunne bruke av arbeidstiden og trekke på nettverksposisjonen. Samtidig savnet de å få moralsk støtte for nødvendig ekstrainnsats. Som én fremholdt i intervju: «Vi er litt «frivillige» inn i dette her, også!»

Jeg vil kort trekke frem noen likhetstrekk mellom etableringsfasen i Vestfold og oppbyggingen av selvhjelpssenteret LINK i Nord-Norge (Nord-Troms) noen år tidligere (se kap. 6). Til tross for store ulikheter $\mathrm{i}$ lokale betingelser resulterte begge i mer permanente strukturer for selvhjelpsarbeid gjennom utstrakt alliansebygging og samarbeid med en rekke ulike aktører. I begge tilfelle var det lokale ildsjeler som dro prosessen, med betydelig bistand fra Selvhjelp Norge/Norsk selvhjelpsforum. I Nord-Troms i form av én privatperson, i Vestfold en gruppe av profesjonelle. En lærdom fra begge prosjekter er at etablering av selvhjelpsarbeid lokalt i stor grad ser ut til å være avhengig av ildsjeler i ulik form; folk med engasjement, stor lokalkunnskap og evne til å identifisere mulighetsrom og til å koble sammen ulike aktører. At det i Vestfold var et kollektiv av profesjonelle som tok rollen som sosial entreprenør og «ildsjel», bidro antakelig til at denne rollen ble mindre tydelig utad og følgelig mottok mindre anerkjennelse (arbeidet hadde heller ikke form av en like stor, personlig innsats som i Nord-Troms).

\section{Ambivalens fra begge sider}

Så langt jeg har informasjon, kan perioden med stillhet i relasjonen mellom Selvhjelp Norge og styringsgruppa ikke knyttes til misforståelser eller manglende signaler fra Vestfold-aktørenes side. Mye taler for at den heller er et uttrykk for et mer generelt og underliggende spenningsforhold.

LMS-forumet fikk etter hvert inntrykk av at det utviklet seg en tvetydighet fra Selvhjelp Norges side. De uttrykte på prosjektmøter og i samtaler med forskeren at utsettelsene av distriktskontoret måtte tolkes som skepsis fra Selvhjelp Norge når det gjaldt deres rolle. 
Rollen som selvhjelpsentreprenør var ikke særegen for aktørene i Vestfoldprosjektet. Det samme gjaldt en stor del av de andre prosjektene innen tilskuddsordningen hvor det også var involvert lærings- og mestringssentre. Mange av de andre dreide seg imidlertid om å sette i gang og høste erfaringer fra grupper på spesifikke (diagnose)områder. Prosjektet i Vestfold hadde derimot videre ambisjoner enn de fleste; målsettingen var å bygge «varige strukturer» for selvhjelpsarbeid. Med det fulgte også etter hvert en viss kritisk holdning til Selvhjelp Norges definisjonsmakt omkring selvhjelp som begrep og praksis.

Flere i Vestfoldprosjektet reagerte på det de oppfattet som en unødvendig «strenghet» fra Selvhjelp Norge sin side og reagerte på at man trakk så tydelige grenser mot andre tilnærminger til selvhjelp som arbeidsform. Så langt de kunne se, hadde den sterke fellestrekk med andre metoder og former for gruppearbeid. Da relasjonen til Selvhjelp Norge var inne i en avventende periode, stilte LMS internt spørsmålet: «Skal vi kalle det selvhjelp, - eller kanskje noe helt annet?». Dette formulerte de i en mer dempet form til Selvhjelp Norge, i form av referat fra diskusjoner i nettverket. De var ikke først og fremst kritiske til selve innholdet i begrepet, men til det de oppfattet som en sterk markering av grensene for bruken av det. Selvhjelp Norge har etablert seg som kompetansesenter med mål om å bidra til sterkere standardisering av begreper og modeller for autonome selvhjelpsgrupper. Det har med andre ord påtatt seg rollen som et «centre of authority» (Star \& Griesemer, 1989) på selvhjelpsfeltet. I samarbeidsrelasjonen med Vestfold-aktørene møter de imidlertid et annet «centre of authority», som forvalter kunnskap på tilstøtende og overlappende felt, og som har lite å tape på å utfordre forståelsen av selvhjelpsbegrepet og praksisen. Dissonansen mellom dem dreier seg slik sett om Selvhjelp Norges definisjonsmakt. LMS vil ikke «eie» begrepet, men, som de sier, ha mulighet for å «gjøre det til sitt» ved å foreta lokale tilpasninger.

Sett utenfra kommer Vestfoldprosjektet etter hvert i en posisjon der de kan utfordre Selvhjelp Norges hegemoni og begrepsforståelse. Selvhjelp Norge er i en rolle som nasjonal premissleverandør og har bidratt til at selvhjelp har blitt et relativt «etablert felt» på nasjonalt nivå. Samtidig er det trekk ved utviklingen i Vestfold som peker mot et «fremvoksende felt» på lokalt nivå, ettersom samhandlingen mellom aktørene ikke er 
rutinisert innenfor en tydelig orden. Hensikten med prosjektet er jo nettopp å utvikle noe nytt. Dette gir rom for ulike vurderinger; et felt som ikke er organisert kjennetegnes gjerne av at aktørene har ulike eller motstridende forståelser av hva som står på spill (Fligstein \& McAdam, 2012; se Zeiner, kapittel 7 i denne boka). I relasjonen mellom Selvhjelp Norge og Vestfoldprosjektet ser vi at partene nettopp har ulik forståelse av «hva som står på spill,» noe som først og fremst kommuniseres indirekte, og som underveis kanskje heller ikke er helt tydelig for dem selv.

\section{«Strenghet» - om standardisering og praktisk tilpasning}

$\mathrm{Da}$ Vestfold-aktørene etter en tid ga uttrykk for at de oppfattet Selvhjelp Norges formidling av selvhjelpsmetoden som «for streng», utfordret de til en viss grad senterets forståelsesmåte og definisjonsmakt. De reagerte med andre ord på det de oppfattet som for mye standardisering.

En viktig nyskaping på selvhjelpsfeltet, også i internasjonal sammenheng, er det vi i denne boka kaller «SN-modellen», som åpner for sammensatte grupper der deltakere kan samles på tvers av problemtyper. ${ }^{14}$ Selvhjelp Norge har gradvis har lagt større vekt på å formidle at disse anbefalte rammene og prinsippene ikke bør rokkes ved. Når selvhjelpsgrupper kan favne de fleste målgrupper og et bredt spekter av problemer, blir det selve arbeidsformen som definerer hva selvhjelp «er».15

For Vestfold-aktørene kan denne opptattheten av en «ren» metode fremstå som litt forvirrende. For dem kan det være vanskelig å forstå

14 Selvhjelp Norge har brukt begrepene «nøytrale grupper» (Selvhjelp Norge, 2010a) og «grupper på tvers» (Godager \& Talseth, 2013, s. 91).

15 I en analyse av nasjonale politikkdokumenter relatert til selvhjelpsarbeid og selvhjelpsforståelse i perioden 1998 til 2011, peker Hedlund og Landstad på noe av det samme. De finner en utvikling fra at selvhjelp defineres bredt som en metode med stor variasjon, til at metoden i sterkere grad «modelleres», og det legges større vekt på at selvhjelp er en praksis som krever tilegning av visse ferdigheter (de tidfester skillet til 2009). Dette skjer parallelt med at selvhjelpsarbeid og selvhjelpsforståelse defineres bredere og gjøres allment, på tvers av problemtyper (Hedlund \& Landstad, 2012, s. 81). Denne utviklingen passer godt til teorien om grenseobjekter og poenget om at de har en tendens til å standardiseres over tid. Forfatterne mener endringene på selvhjelpsfeltet bidrar til er en generell trend med individualisering av ansvar for håndtering av egen helse (health conditions) og at erfaringskunnskap i dette tilfellet nedprioritereres til fordel for en profesjonalisering av selvhjelpsvirksomhet. 
hvorfor entydighet i retningslinjene er så viktig når selvhjelpsbegrepet og idéen er såpass vid og inkluderende. Det er verdt å merke seg at fagpersonene i Vestfold i hovedsak fulgte Selvhjelp Norges rammer og prinsipper. Blant de viktigste (ved siden av anonymitet og konfidensialitet) er at deltakelse er frivillig, grupper kan settes i gang av en igangsetter, men er deretter lederløse og autonome, gruppa lukkes ved oppstart og tar ikke inn nye deltakere underveis, arbeidet har «åpen ende» ved at deltakerne holder sammen så lenge de finner det tjenlig (i motsetning til et kurs), og tema for samtalene skal ikke konsentreres rundt praktiske problemer eller tema, men først og fremst ta utgangspunkt i deltakernes følelsesmessige opplevelse av livssituasjonen og relasjonene i gruppa «her og nå». LMS-forumet utfordret heller ikke modellen direkte, ved å foreslå konkrete endringer overfor Selvhjelp Norge.

I SN-modellen utfordres grenseobjektets krav om gjenkjennelighet når det ikke er konsentrert rundt et felles problem eller en felles identitet. Det blir et særegent spenn mellom hvordan grenseobjektet (selvhjelp) blir løst definert i allmenn bruk og strammere definert for konkret bruk, fordi den allmenne bruken skal favne et svært vidt spekter av problemer og nå ut til hele befolkningen. Men ettersom Selvhjelp Norge, i likhet med LMS, er en grenseorganisasjon hvis eksistens er basert på kontinuerlig å inngå i samarbeidsrelasjoner, kan det gi forventninger hos samarbeidspartnere om «forhandlinger» og tilpasninger utover det praktiske. En slik forventning gjelder ikke for en organisasjon som AA, som ikke baserer seg på samarbeidsnettverk og derfor ikke trenger å forhandle om eller tilpasse grenseobjektet overfor andre aktører.

I forskningsprosjektet som helhet ser vi at for Selvhjelp Norge - som har påtatt seg rollen som et nasjonalt koordinerende senter, informasjonsformidler og politisk pådriver - er det derimot viktig at en tydelig beskrivelse av «selvorganisert selvhjelp» kan formidles bredt og samtidig være konkret nok til å oppnå anerkjennelse hos myndigheter og fagmiljøer. Ut fra observasjons- og intervjumaterialet i Vestfoldprosjektet ser det imidlertid ut til at standardiseringen av metoden medfører at de lokale samarbeidende aktørene i Vestfold får problemer med å identifisere seg med måten selvhjelpsarbeid presenteres på. De reagerer blant annet på at 
deler av virksomheten, som aktørene selv forstår som selvhjelpsarbeid, ikke passer inn i den sentralt gitte definisjonen.

Da Selvhjelp Norge i en periode viste en viss tilbakeholdenhet overfor Vestfoldprosjektet, tolker jeg det som et uttrykk for at de var bekymret for at LMS-forumet etter hvert skulle bli egenrådig og opparbeide seg så mye egenerfaring at de kunne komme til å endre vesentlig deler av metoden. I alt formidlingsarbeid, spesielt overfor helsetjenestene, markerer senteret skillet mellom selvhjelp og behandling. For eksempel er de nøye med at selvhjelp skal omtales som en «mulighet» og ikke et «tilbud», en betegnelse de mener kan gi inntrykk av selvhjelp som en aktivitet i regi av det offentlige. Bekymringen for fragmentering - at grenseobjektet så å si skal falle fra hverandre, tilbake til sine ulike sosiale verdener - er såpass stor at den koordinerende enheten Selvhjelp Norge tillater liten grad av tillemping. Bekymringen for kooptering, at profesjonene skulle ta over metoden og gjøre den til noe annet, er heller ikke ubegrunnet. LMS-forumet hadde den faglige og institusjonelle styrken og legitimiteten til eventuelt å omforme metoden, uten at det ville ha fremtidige omkostninger for dem. For dem var selvhjelpsmetodikk ett av mange redskap i en bred verktøykasse. Antakelig er det vanskelig for LMS-forumet å se at de kan virke truende på Selvhjelp Norges forståelse av selvhjelparbeidets autonomi. Ut fra sin egen selvforståelse praktiserer den en pragmatisk og lite «ideologisk» tilnærming. Men ved siden av større institusjonell styrke er det nettopp denne viljen til pragmatisme og «urenhet» som kan virke utfordrende for Selvhjelp Norges mer «rene» selvhjelpsforståelse.

\section{Konklusjon}

Oppbyggingen av selvhjelpsarbeidet i Vestfold er et eksempel på sosialt entreprenørskap hvor lokale ressurser (LMS) og nasjonale ressurser (Selvhjelp Norge) flettes sammen i grenseflater mellom ulike kunnskapsformer og sivilsamfunns- og myndighetsstrukturer. I møtet mellom Selvhjelp Norge og LMS-ene møtes to tradisjoner som har mye felles, og som samtidig er ulike på viktige måter. Det dreier seg særlig om hvordan og i hvilken grad erfaringskunnskap kan gis et eget rom, og graden av institusjonelt rammeverk for å forvalte denne kunnskapen. 
Når jeg har løftet frem former for ambivalens i et ellers vellykket samarbeidsprosjekt, er det fordi de fungerer som en linse som illustrerer et generelt spenningsforhold i selvhjelpens relasjon til profesjonene og helsetjenestene. Det går en historisk linje fra selvhjelpbevegelsens fremvekst nasjonalt og internasjonalt til samarbeidsrelasjonen mellom Selvhjelp Norge og helsearbeiderne i Vestfold. Denne kontinuiteten dreier seg om forholdet mellom autonomi og integrasjon. Selvhjelpens egenart og eksistensberettigelse ligger i den flate strukturen og kunnskapsproduksjon uten faglig ekspertise. En avveining er hvordan selvhjelpsarbeid kan forvalte denne identiteten i nærkontakt med praksiser og felt som selvhjelpsarbeid har store likheter med, og samtidig definerer seg som forskjellig fra.

Ifølge Stokken (2015) er grenseobjekter spesielt egnet for å gi rom for erfaringskunnskap, fordi de gir stort rom for fleksibilitet og innebærer begrenset grad av standardisering, samtidig som de gir nok standardisering til å sikre beskyttende rammer for denne kunnskapen. Star og Griesemer (1989) hevder at grenseobjekter har en tendens til å standardiseres over tid. I en viss grad skjer det med selvhjelpsarbeid når det legges stor vekt på rammer og prinsipper. Sett $\mathrm{i}$ lys av teorien om grenseobjekter fordrer dette at man samtidig klarer å opprettholde plastisiteten og sammensattheten i grenseobjektet. Vestfold-aktørene oppfattet imidlertid standardene som «for strenge», og utfordret til en viss grad forståelsesmåten og definisjonsmakten til Selvhjelp Norge. De er ikke avhengig av å bevare strukturen til grenseobjektet selvhjelp (men de kan bruke det til å bygge oppunder sitt eget grenseobjekt, standard metode/pasientopplæringen). Dette i motsetning til Selvhjelp Norge, som har som en hovedoppgave å formidle grenseobjektet til stadig nye aktører på en rekke ulike felt. Da er de avhengig av gjenkjennelighet på tvers av disse feltene, men uten å gjøre det så standardisert at det ikke oppfattes som lokalt relevant for hver enkelt av dem.

Grenseobjekter er verdifulle måter å organisere sosial praksis på, nettopp fordi de gir stort rom for sammensatthet og tvetydighet. De representerer en anerkjennelse av «borderlands», av produktive mellomrom som motsetter seg entydighet og sterk standardisering. Dette er en verdifull kvalitet og en form for motmakt i et samfunn som i stor grad intensiverer diagnostiserende og spesialiserende prosesser. Da er det avgjørende at man holder fast i og utvikler grenseobjektets særtrekk. Det innebærer 
et vedvarende spørsmål om, hvordan og i hvilken grad den livsnære erfaringskunnskapen som selvhjelpsgruppene representerer, trenger en viss standardisering og institusjonell «beskyttelse» for å bli verdsatt og synlig, uten å bli kooptert av profesjonskunnskapen.

\section{Referanser}

Abbott, A. (1988). The system of professions: an essay on the division of expert labor. Chicago: University of Chicago Press.

Alm Andreassen, T. (2006). Truet frivillighet og forvitrede folkebevegelser? En diskusjon av hva perspektiver fra studier av sosiale bevegelser kan tilføre forskningen om frivillige organisasjoner. Sosiologisk tidsskrift, 14, 146-170.

Alm Andreassen, T. (2011). Innovasjoner som kjempes fram: Fra politisk nytenkning til institusjonell nyskaping. I H. C. Garmann Johnsen \& Ø. Pålshauen (Red.), Hva er innovasjon? Perspektiver i norsk innovasjonsforskning. Bind 1: System og institusjon. Kristiansand: Høyskoleforlaget.

Askheim, O. P. (Red.). (2007). Empowerment i teori og praksis. Oslo: Gyldendal akademisk.

Borkman, T. (1976). Experiential knowledge: A new concept for the analysis of self-help groups. Social Service Review, 50(3), 445-456. https://doi. org/10.1086/643401

Borkman, T. (1990). Self-help groups at the turning point: Emerging egalitarian alliances with the formal health care system? American Journal of Community Psychology, 18 (2), 321-332. https://doi.org/10.1007/BFoo931307

Borkman, T. (1999). Understanding self-help/mutual aid: Experiential learning in the commons. New Brunswick, N.J.: Rutgers University Press.

Fligstein, N. \& McAdam, D. (2012). A theory of fields. Oxford: Oxford University Press.

Giskeødegård, M. F. (2016). O organization, where a thou? Tracing the multiple layers of ambiguous and shifting boundary processes in a formal organization. Journal of Business Anthropology, 5(1), 116-136.

Gjøsæter, Å. \& Kyvik, Ø. (2015). Er høyere organisasjons- og ledelsesstudier egnet for utvikling av reflekterte praksisaktører? Uniped, 38 (o1), 40-52.

Godager, E. V. \& Talseth, S. (2013). Selvhjelp: Om å ta tak i eget liv sammen med andre. Oslo: Z-forlag.

Gotaas, N. (2012). Etablering og igangsetting av selvhjelpsgrupper. NIBR-rapport 2012:8. Oslo: Norsk institutt for by- og regionforskning.

Grimen, H. (2008). Profesjon og kunnskap. I (s. 71-86). Oslo: Universitetsforl., cop. 2008. 
Hedlund, M. \& Landstad, B. (2012). The construction of self-help in Norwegian health policy. International Journal of Self Help and Self Care, 6 (1), 65.

Høgsbro, K. (2012). Social policy and self-help in Denmark - a Foucauldian perspective. International Journal of Self-Help and Self-Care, Vol. 6 (1) 43-64.

Karlsson, M. (1997). Självhjälpsgrupper i Sverige. En introduktion. I Sköndals institutets skriftserie nr. 9.

Katz, A. H. \& Bender, E. I. (1976). Self-help groups in Western society: History and prospects. The Journal of Applied Behavioral Science, 12 (3), 265-282.

Kolb, D. A. (200o). Den erfaringsbaserede læreproces (1984). I K. Illeris, P. Mikkelsen \& R. Damkjær (Red.), Tekster om loering. Frederiksberg: Roskilde Universitetsforlag.

Ramsdal, H., Hansen, G. V., Helgesen, M. \& Feiring, M. (2008). The social and cognitive mapping of policy. Orientation 1, Final Report, WP6, February 2008, vol. Project $\mathrm{n}^{\circ}$ 0288848-2 co funded by the European Commission within the Sixth Framework Program. Brussel: www.knowandpol.eu.

Repstad, P. (1998). Den Lokale velferdsblanding: Når offentlige og frivillige skal samarbeide. Oslo: Universitetsforlaget.

Selvhjelp Norge. (2010). Lesebok om selvorganisert selvhjelp. Oslo: Selvhjelp Norge.

Star, S. L. (1988). The structure of ill-structured solutions: Boundary objects and heterogenous distributed problem solving. I M. N. Huhns \& L. Gasser (Red.), Readings in distributed artificial intelligence. Menlo Park, CA: Morgan Kaufmann.

Star, S. L. \& Griesemer, J. R. (1989). Institutional ecology, 'translations' and boundary objects: Amateurs and professionals in Berkeley's Museum of Vertebrate Zoology, 1907-39. Social Studies of Science, 19 (3), 387-420. https://doi. org/10.1177/030631289019003001

Stokken, R. (2015). Janusian liminality: A key to the accountability of the equality between users and professionals in patient education in Norway. Trondheim: NTNU.

Talseth, S., Godager, E. V. \& Bruland, S. F. (2004). Selvhjelp som prinsipp i forståelsen av psykisk helsearbeid. Sterkere nettverk og nytt samvirke med erfaringsbasert kunnskap kunnskap? Tidsskrift for psykisk helsearbeid, o1(01), 55-62.

Trägårdh, L. (1997). Statist individualism. I Ø. Sørensen \& B. Stråth (Red.), The cultural construction of Norden. Oslo: Scandinavian University Press. 



\title{
Nasjonal selvhjelpssatsing møter lokalsamfunnet
}

\author{
Marte Feiring \\ Fakultet for helsevitenskap, OsloMet -Storbyuniversitetet
}

\begin{abstract}
The chapter studies how a national self-help actor cooperates with a local Norwegian community about self-help work. It analyses this cooperation as a type of boundary work passing several challenges: The initiating work by the self-help actor moves from one-sided information work to negotiations with the local authorities, where the primary objective is to create a common understanding of self-help. Later, expanded networking and a type of translation of the understanding of self-help to new actors and situations are taking place. The main project for the self-help actor was to create a common understanding of self-help, meeting places for self-help groups and networks. The chapter concludes that the most challenging stage was the networking activities including the translation of the common understanding of self-help.
\end{abstract}

Keywords: boundary work, boundary object, embodied knowledge, self-help work, self-help groups, translation.

\section{Innledning ${ }^{1}$}

Dette kapittelet analyserer en samarbeidsprosess mellom en nasjonal selvhjelpsaktør og en bykommune om utformingen av selvhjelpsarbeid i et lokalsamfunn. Mitt anliggende er å se på hvordan det nasjonale initiativet til samarbeid om selvhjelpaktiviteter forhandles om og forankres i en lokalpolitisk kontekst. Jeg er samtidig interessert i hvilke faktorer som er i spill når aktørene lykkes i noen situasjoner, men ikke i andre.

$1 \quad$ En tidligere utgave av dette kapittelet er publisert i notatet: Endringsarbeid $i$ selvhjelpsgrupper perspektiver på deltakelse og samarbeid. I Å. Brottveit \& M. Feiring (Red.), Oslo: Norsk institutt for by-og regionforskning, Diakonhjemmets høgskole og Høgskolen i Oslo og Akershus.

Sitering av dette kapittelet: Feiring M. (2019). Nasjonal selvhjelpssatsing møter lokalsamfunnet. I Å. Brottveit \& M. Feiring (Red.), Samarbeid om selvhjelp. En antologi om den nye selvhjelpsbevegelsen i Norge (s. 115-137). Oslo: Cappelen Damm Akademisk. https://doi.org/10.23865/noasp.68.ch5

Lisens: CC BY 4.0 
Den ene hovedaktøren i denne studien er Norsk selvhjelpsforum, en stiftelse etablert 1998 og som omtaler seg som rådgiver for offentlige og frivillige organisasjoner. Stiftelsen er i dag ansvarlig for driften av to selvhjelpssentra: et nasjonalt kompetansesenter, Selvhjelp Norge, som arbeider på oppdrag fra Helsedirektoratet; og et lokalt senter for selvhjelp og mestring for hovedstadsregionen (Helsedirektoratet, 2014; Sosial- og helsedirektoratet, 2004). Det lokale senteret for selvhjelp og mestring startet i 1999 og ble etter få år finansiert over kommunens budsjett. Slike sentra omtales også som møteplasser, eller LINK - som er et akronym for: Læring, Informasjon, Nettverk og Kunnskap. Det nasjonale kompetansesenteret - Selvhjelp Norge åpnet i 2006, og har fra starten av mottatt statlig finansiering. Hovedoppgavene til Selvhjelp Norge beskrives som informasjonsarbeid, kunnskapsformidling og nettverksarbeid, dette er oppgaver som er nedfelt i Nasjonal plan for selvhjelp (Helsedirektoratet, 2014; Sosial- og helsedirektoratet, 2004). Kompetansesenteret består i dag av syv regionale enheter, omtalt som distriktskontorer, og de arbeider for å skape møteplasser for selvhjelpsarbeid i sitt område (Feiring, 2013). Selvhjelp Norge er opprettet i samarbeid med nasjonale helsemyndigheter som et instrument i en nasjonal satsing på selvhjelp. Satsingen har en hybrid organisasjonsform og kan kalles et offentligsivilt samarbeid. Norsk selvhjelpsforum og Selvhjelp Norge betegnes i denne boka som representanter for den nye selvhjelpsbevegelsen (se kapittel 1).

Den andre sentrale aktøren i denne studien er en bykommune på Østlandet, som er administrativt senter og nærmeste by for en befolkning på omlag 30 ooo. I tillegg til tradisjonelle helse- og velferdstjenester, har byen et kommunalt rehabiliteringssenter, en frisklivssentral og en frivilligsentral. Samtidig er det lokalisert en rekke spesialiserte helseinstitusjoner i byen, blant annet lokalsykehus, spesialistsykehus og en privat rehabiliteringsinstitusjon. Begge sykehusene har lærings- og mestringssentre som tilbyr selvhjelpsrelaterte aktiviteter, mens rehabiliteringsinstitusjonen supplerer sitt faglige tilbud med «livsstyrketrening». De spesialiserte helsetjenestene arbeider både med «veiledet eller profesjonsledet selvhjelpsarbeid» og samarbeider med brukerorganisasjoner om ulike former for «likepersonsarbeid» (se kapittel 3).

Temaet i dette kapittelet er en samarbeidsprosess mellom den nasjonale selvhjelpsaktøren og bykommunen. Jeg er interessert i å studere de 
ulike aktørenes forståelse og utøvelse av dette samarbeidet slik dette er dokumentert gjennom diverse skriftlige og muntlige kilder.

\section{Teori og metode}

Historisk sett har selvhjelpsaktiviteter vært betraktet som en kulturell motpol til profesjonenes og spesielt psykologenes arbeid, mens dette i dag er sammenkoblet i det Illouz $(2008$, s. 36, 166) kaller et hybridisert kulturelt system. Noe av bakgrunnen for denne motsetningsfylte alliansen forklares med at psykologenes og psykoterapiens språk har beveget seg fra terapirommet og inn i den sivile kulturen hvor det er blitt tatt i bruk av lekfolk. Illouz' resonnement er beslektet med Brown et al. (2004), som har identifisert en ny aktør innen helsefeltet - omtalt som «embodied health movements' eller grensebevegelser. Den nye aktøren har tre spesifikke kjennetegn: i) den forholder seg til kroppsliggjort erfaring, ii) den utfordrer tradisjonell vitenskapelig og medisinsk kunnskap og praksis, og iii) den samarbeider med profesjonelle og offentlige myndigheter for å fremme helse eller forebygge sykdom. Dette er treffende karakteristika for selvhjelpsaktøren i denne studien. Det nasjonale kompetansesenteret, Selvhjelp Norge, er primært basert på erfaringskunnskap, samtidig som de ansatte har ulik faglig bakgrunn. Norsk selvhjelpsforum, som driver dette kompetansesenteret, er tydelig på at selvhjelp skal være et supplement og et alternativ til behandlingsmåter i det ordinære helsevesenet. Norsk selvhjelpsforum og Selvhjelp Norge utgjør ikke alene en ny sosial bevegelse, men de kan betraktes som representanter for det jeg vil omtale som en ny aktør innenfor slike bevegelser. Brown et al. (2004) framhever ytterligere et kjennetegn ved de nye grensebevegelsene - de anvender såkalte grenseobjekter. ${ }^{2}$

Ifølge Star (1987) er det å skape og håndtere grenseobjekter en nøkkelprosess i ethvert samarbeid på tvers av ulike sosiale verdener (Star \& Griesemer, 1989). Et samarbeid mellom ulike aktører vil innebære en form for oversettelse eller translasjon mellom aktører som representerer ulike verdener. Star (1987) lanserte ordet grenseobjekt som en betegnelse

2 Grenseobjekt og grensearbeid som analytiske begrep er presentert utførlig i innledningskapittelet. 
på fenomener som overlapper ulike sosiale verdener (her er representert ved sivile og offentlige aktører) og som er elastiske nok til å bli oversatt og anerkjent av begge parter. Et grenseobjekt kan være en felles idé, et felles lokale, et forum eller et felles prosjekt. Grenseobjekt er et begrep for det som ligger i randsonen og som ofte tas for gitt av aktørene som deltar i samarbeidet. Det kan være mange forskjellige typer fenomener som får et samarbeid til å fungere i praksis. I denne sammenheng er et grenseobjekt et analytisk begrep for det som tilfredsstiller de ulike aktørenes krav til innhold og mening; det er plastisk nok til å tilpasse seg aktørspesifikke behov, og det dekker over det som er motsetningsfylt mellom aktørene, samtidig som det opprettholder en form for felles identitet hos aktørene (Bowker \& Star, 200o). Jeg vil vise hvordan utformingen av grenseobjekter skjer i et samvirke mellom kommunale og sivile aktører i form av oversettelser og forhandlinger og det som jeg her betegner som grensearbeid (Gieryn, 1983).

I dette kapittelet ser jeg på hvordan offentlige og sivile aktører samarbeider om integrering av en nasjonal satsing på selvhjelparbeid i et lokalsamfunn. Min studie forsøker å analysere hvordan aktørene gjennom former for grensearbeid håndterer ulike forståelser av selvhjelp og hvordan de skaper grenseobjekter, i betydningen fenomener som kan fungere som felles interesse- og identitetsprosjekter.

For å studere dette temaet har jeg fulgt en samarbeidsprosess mellom to aktører over en periode på fire år. Det primære materialet er tekster utformet og anvendt av de to hovedaktørene. Jeg har nærlest to hovedtekster, Nasjonal plan for selvhjelp (2004-2013) og Kommunedelplan omsorgstjenester (2010-2013) ${ }^{3}$ og omlag 20 omtaler i lokale media samt annet tekst- og brosjyremateriell utformet primært av selvhjelpsaktørene. I tillegg har jeg analysert planarbeider, møtedokumenter og omtaler i media.

Utover dette har jeg observert formelle og uformelle møter, samt foretatt intervjuer av sentrale aktører (Gubrium \& Holstein, 2009; Prior, 2003). Samlet sett er det foretatt tolv møteobservasjoner og fem observasjoner av

3 I tillegg er Kommunedelplan omsorgstjenester (2009-2021) og Norsk selvhjelpsplan (20142018) vist til som del av en større kontekst. 
andre sammenkomster. Det er utført til sammen åtte intervjuer av seks personer, tre fra kommunen og tre fra selvhjelpområdet. Tekstmaterialet er gjennomgått flere ganger, og sitater eller ord som handler om samarbeidsprosessen er strategisk utvalgt. Analysen er foretatt med utgangspunkt i begrepene manifest intertekstualitet, som sier noe om hvordan de ulike tekstene relaterer seg til hverandre som historiske dokumenter, og konstitutiv intertekstualitet,som ser på hvordan dialogen eller utsagnene relaterer seg til hverandre som ledd i en tekstkjede (Fairclough, 1992). ${ }^{4}$ Notatene fra observasjonene og utskriftene fra intervjuene er primært anvendt for å kontekstualisere og supplere de øvrige skriftlige tekstene og deres forfattere.

\section{Selvhjelp på den lokalpolitiske dagsordenen}

Fra den nasjonale selvhjelpsaktøren tok det første initiativet overfor bykommunen våren 2009, og til selvhjelpsgrupper er innskrevet som aktivitet i det kommunale handlingsprogrammet, gikk det bare noen få måneder. I denne perioden var bykommunen opptatt av planlegging og budsjettering av de framtidige helse- og omsorgstjenestene, mens selvhjelpsaktøren hadde informasjon og kunnskapsformidling om selvhjelp til lokalbefolkningen som sin hovedoppgave. De to aktørene representerer langt på vei to ulike sosiale verdener.

\section{En kommunal omstillingsprosess - konteksten}

Sett fra bykommunens ståsted var premissene for offentlig tjenesteformidling i endring. Samhandlingsreformen, innført fra 2012, var under planlegging og hadde som mål å delegere store og nye helse- og omsorgsoppgaver til kommunene. Denne reformen innebærer, som kjent, endringer i oppgavefordelingen mellom sykehus og kommune og dermed også en forventet volumøkning av kommunale tjenester og brukere (Helse- og omsorgsdepartementet, 2008). Noe senere lanserte et offentlig

4 Konstitutiv intertekstualitet er av Fairclough (2003) omtalt som interdiskursivitet. 
ekspertutvalg begrepet «den andre samhandlingsreformen» om et utvidet samarbeid med sivile aktører og befolkningen (NOU 2011:11, 2011).

Bykommunen hadde allerede deltatt i flere samarbeid med nabokommunene om utvikling av helse- og omsorgstjenestene, 5 og de aktuelle kommunene hadde dannet en lokal helseregion som er en interkommunal samhandlingspart med sykehusforetaket. Dette betyr at da selvhjelpsaktøren startet sitt informasjonsarbeid i regionen, var kommunen allerede i gang med en omfattende nasjonalt initiert endringsprosess. I sentrale plandokumenter etterlyser vår bykommune nye arbeidsformer og nye måter å løse helse- og omsorgsoppgavene på:

I årene som kommer skal tjenestene dimensjoneres for å møte ytterligere oppgaver og volumvekst. Skal vi lykkes kan vi ikke bare gjøre mer av det vi allerede gjør. Vi må utvikle nye arbeidsformer og nye måter å løse enkelte oppgaver på. Fokuset må i større grad dreies fra reparasjon av konsekvenser til forebygging og tidlig intervensjon i pasient- og problemforløpene. (Kommunedelplan omsorgstjenester, 26 august 2009, Forordet, s. 5)

Kommunen er opptatt av å finne nye arbeidsformer for å løse befolkningens helse- og omsorgsbehov. I plandokumentet etterlyser de samtidig et tettere samarbeid med frivillige lag og lokalsamfunnets mange organisasjoner (Kommunedelplan omsorgstjenester 2009, 26 august). Dette viser at kommunen er interessert $i$ et nærmere samarbeid med nye organisasjoner, og den nasjonale selvhjelpsaktøren representerer nettopp dette. Jeg spør her om dette nye samarbeidet kan betraktes som grensearbeid mellom offentlige myndigheter og sivile aktører (Gieryn, 1983, 1999).

Om det nye samarbeidet sier en representant fra kommunen:

Vi må erkjenne at vi som tjeneste ikke klarer å løse alle problemer for folk og det offentlige ikke kan ha mål i seg for det: Skal en leve det gode liv må en ta ansvar for det selv. Folk må bli aktører i eget liv. Profesjonene kan ikke ta ansvaret for dette. (Kommunal aktør)

5 http://www.komutprosjektet.no, lastet ned i september 2012.

http://www.trustprosjektet.no/; lastet ned i september 2012.

http://www.Lillehammer.kommune.no/trust.4930591-188871.html, lastet ned i september 2012. 
En representant for den nasjonale selvhjelpsaktøren kommenterer det samme temaet slik i et intervju: «Kommunen ser på selvorganisert selvhjelp som et arbeid som kan styrke den enkeltes mulighet for egenomsorg».

Formuleringene «ta ansvar for seg selv», «bli aktør i eget liv» og «styrke mulighet for egenomsorg» er ulike, men ikke direkte motstridende. Utsagnene fra de to aktørene kan tolkes som oversettelser av hverandres språkbruk og er slik sett eksempler på det jeg her omtaler som grensearbeid (Gieryn, 1983, 1999).

\title{
Selvhjelpsaktørens informasjonsarbeid
}

Ett av de første sporene av den nasjonale satsingen på selvhjelp kan vi finne i en av de lokale avisene under overskriften: «Et positivt vågestykke. Kunne du tenke deg å være en positiv drivkraft for andre?»

\begin{abstract}
Selvhjelp Norges satsing ... betyr blant annet etablering av et samhandlingsnettverk mellom det offentlige, frivillige organisasjoner, bruker- og interesseorganisasjoner og profesjonsgrupper. ... Selvhjelp ... handler om ... en grunnleggende forståelse av at alle har ressurser og krefter som kan tas i bruk, også når livet ikke går på skinner. ... Hvis man sliter med et problem eller er syk, er det viktig å ta bruk sin egen erfaring. Vi har litt for ofte lett for å løpe ut for å hente ekspertise og glemmer at egen livserfaring kan være nyttig redskap i prosessen med å få et bedre liv. ... Vår jobb er blant annet å lære opp igangsettere av grupper og komme i kontakt med miljøer som ønsker å være med i etableringsfasen av selvhjelpsgrupper. (Ernestus, 2009, 3. september)
\end{abstract}

Den nasjonale selvhjelpsaktøren inviterer her til et bredt samarbeid med lokale aktører. De ønsker å opprette et samhandlingsnettverk mellom ulike offentlige og frivillige organisasjoner og grupper. Samtidig tilbyr de opplæring av lokale igangsettere av selvhjelpsgrupper. ${ }^{6}$ Samhandlingsreformens vektlegging av forebyggende arbeid, og ytterligere oppgaveoverføring til kommunene, framheves også. Det kommer tydelig fram i avisartikkelen at Selvhjelp Norge er et kompetansesenter finansiert av

6 Med igangsettere menes her lekfolk som ønsker å bidra til oppstart av en selvhjelpsgruppe. 
nasjonale helsemyndigheter. Siden Selvhjelp Norge er administrativt ledet av en sivil aktør, Norsk selvhjelpsforum, ser vi på den nasjonale selvhjelpssatsingen som en del av det Illouz (2008) omtaler som et hybridisert kulturelt system - i betydningen en sammenveving av språkbruk fra ulike verdener.

Den lokale byavisen følger opp temaet med et felles intervju med den lokale frivilligsentralen og det nasjonale kompetansesenteret. Under overskriften «Bygge broer med selvhjelp» kan vi lese følgende:

[Byens] frivilligsentral starter i høst nye sorg- og angstgrupper, og parallelt starter Selvhjelp Norge kurs for igangsettere av selvhjelpsgrupper. Det skaper et samarbeid som bygger broer. Angstgruppene er for dem som ikke sliter med tunge lidelser og psykoser. Rett og slett for dem som har møtt veggen i ulike livssituasjoner. ... Sorg blir ofte veldig fort en tilbakelagt historie for alle rundt deg, men selv er du kanskje ikke ferdig. Sorg er ikke farlig - bare smertefullt. Målet er å komme videre og føle at en har fått snakket ut, og man sier ikke mer enn man vil (Representant fra frivilligsentralen).

Vi må hjelpe hverandre med å «allmenngjøre» livsproblemer, fysiske like mye som psykiske. ... Det har vist seg at det lønner seg å snakke sammen. ... Selvhjelp er å gripe tak i egne muligheter og ta ansvar for livet sitt selv og styre livet i den retningen en ønsker. ... I dag sitter vi ofte på hver vår tue med mye erfaringer som ikke utveksles, og da handler det om å bygge broer. Her er blant annet frivilligsentralene viktige kontaktpunkter sammen med blant annet Mental Helse, Landsforeningen for trafikkskadde og andre interesseorganisasjoner innen helse (Representant fra selvhjelpsaktøren). (Vold, 2009, 18. juni)

Overskriften fremhever «brobygging» med den lokale frivilligsentralen som har lang erfaring med selvhjelpsgrupper, og det presiseres i tekstutdraget at den nasjonale selvhjelpssatsingen er opptatt av å bygge broer med frivillige organisasjoner. I en og samme artikkel promoteres både eksisterende selvhjelpsgrupper i regi av den lokale frivilligsentralen og den nye nasjonale satsingen på selvhjelpsarbeid med vekt på erfaringsutveksling og nettverkssamarbeid.

I tillegg til lokal mediaomtale, formidles informasjon om selvhjelp gjennom møter med politikere, kommunale tjenesteledere, andre ansatte i helse- og omsorgstjenestene og i befolkningen for øvrig. Den nasjonale 
planen for selvhjelp (Sosial- og helsedirektoratet, 2004) introduseres slik i et egenprodusert informasjonsmaterialet:

Nasjonal plan for selvhjelp - en plan for egenkraftmobilisering og ny helseforståelse. Alle mennesker har iboende ressurser som kan aktiveres, gjenerobres og mobiliseres, når livsproblemer oppstår, selvhjelp er å ta dem i bruk. (Informasjonsmateriell, 27.08.2009)

Et nærmere blikk på informasjonsmaterialet som Selvhjelp Norge har produsert og anvender, klassifiserer for det jeg vil kalle et selvhjelpsspråk. De bruker egne ord og formuleringer som for eksempel «egenkraftmobilisering» og «iboende ressurser som skal gjenerobres og mobiliseres». Dette er samtidig en noe annen språkstil enn vi finner i lokale aviser. I tillegg er informasjonsmaterialet preget av en personlig stil: «til deg [som deg], deg som fagperson, deg som politiker, deg som pårørende, deg som arbeidskollega, deg som arbeidsgiver, deg som ektefelle og samboer».? Jeg vil si at denne språkbruken er mer beslektet med reklamebransjen enn med helse- og omsorgstjenestene. De sentrale temaene på de lokale informasjonsmøtene omtales som «selvhjelp og psykisk helse i et folkehelseperspektiv - selvhjelp og selvhjelpsgrupper - selvhjelpsforståelse - hva og for hvem - praktiske rammer - vår egen rolle i selvhjelpsarbeidet - de profesjonelles rolle i selvhjelpsarbeidet - satsing på selvhjelp». ${ }^{8}$ Målgruppen for den nasjonale satsingen er bred, og selvhjelpsaktøren har som ambisjon at alle i Norge skal vite om selvhjelpsgrupper, dersom hverdagsproblemene blir for utfordrende å løse på egen hånd: «Selvhjelp kan fungere både forebyggende og rehabiliterende - med eller uten diagnose, men også under behandling.» ${ }^{9}$

Denne form for informasjonsarbeid kan betraktes som en kommunikasjonsstrategi for å påvirke lokale forståelser av hva den enkelte selv kan bidra med for å bedre egen helse. Informasjonskampanjen kan samtidig oppfattes som et svar på utfordringene kommunen står overfor med den nye store helsereformen (Jf. samhandlingsreformen). Kommunen er opptatt av at den enkelte samfunnsborger skulle aktiveres mer for å bedre

Invitasjon til informasjonsmøte, 2009, 16. juni. Arkivmateriale.

Invitasjon til informasjonsmøte, 2009, 16. juni. Arkivmateriale.

Informasjonsmateriell, lastet ned, 14. februar i 2011, fra Selvhjelp Norge. 
egen helse. Samtidig var tilbudene om opplæring i regi av det nasjonale kompetansesenteret kostnadsfrie, og den nasjonale satsingen var på oppdrag av statlige helsemyndigheter. Fordi selvhjelpsaktøren representerer både sivilsamfunnet og statlige helsemyndigheter, var det enklere å formidle budskapet om selvhjelpsarbeid overfor de ulike aktørene i et lokalsamfunn. De kommunale myndighetene ser ut til å ha betraktet den nasjonale selvhjelpssatsingen som et ledd i den nye helsepolitikken, mens de lokale sivile aktørene kan ha vurdert det samme initiativet som en innsats for det frivillige arbeidet.

I dette arbeidet - eller snarere grensearbeidet - blir informasjon om selvhjelp kommunisert på mange ulike måter: i lokalavisen, på møter og gjennom informasjonsbrosjyrer direkte til profesjoner og befolkningen samt i form av opplæring av personer som vil igangsette nye selvhjelpsgrupper. Målet ser ut til å være formidling av informasjon om selvhjelp som en ny arbeidsmåte i både behandlende og forebyggende helsearbeid. Erfaringene fra selvhjelpsarbeid oversettes bredt, til kommunale ledere, helsearbeidere, frivillige og til befolkningen for øvrig. Det at selvhjelpsaktøren er del av et offentlig-sivilt samarbeid ser ut til å ha vært et viktig moment for kommunal tilslutning.

\section{Selvhjelpsaktiviteter representeres i kommunalt handlingsprogram}

Det neste språklige avtrykket, som den nasjonale selvhjelpsaktøren setter lokalt, er inkludering av selvhjelpsaktiviteter i det kommunale planarbeidet. I det lokalpolitiske handlingsprogrammet for perioden 2010-2013 viser kommunen til selvhjelp og selvhjelpsgrupper flere steder. Det står i planen at kommunen skal: «Utvikle selvhjelp som en del av helsetilbudet. Etablere selvhjelpsgrupper i samarbeid og samhandling med Norsk selvhjelpsforum..$^{10}$ Dette eksemplifiseres som grupper for personer med diabetes eller demens, for pårørende eller personer som er i et rehabiliteringsløp. Det spesifiseres at Norsk selvhjelpsforum skal delta i dette

10 Strategi-og økonomiplan 2010-2013. (Handlingsprogram, punkt 8, s. 45). 
arbeidet sammen med hjemmetjenestene, rehabiliteringssenteret, tildelingskontor og det lokale NAV-kontoret. ${ }^{11}$

Videre omtaler handlingsprogrammet selvhjelpsgrupper sammen med egne spesialiserte tjenester for å: «Utvikle målrettede frivillige gruppetilbud på dagtid til definerte pasientgrupper med behov for spesialisert kompetanse». Tiltaket knyttes til «spesialiserte fagteam» og «selvhjelpsgrupper» samt «samhandlingsprosjektet», sistnevnte er et interkommunalt helsesamarbeid. ${ }^{12}$ En rekke aktører nevnes som deltakere: sykehjem, hjemmetjenestene, rehabiliteringssenteret, fastlege, frivillighetssentral, lag, foreninger og brukerorganisasjoner, men her er ikke Norsk selvhjelpsforum nevnt. Dette viser at selvhjelp i regi av den nasjonale aktøren omtales i handlingsprogrammet sammen med de offentlige helsetjenestene, men det nevnes ikke sammen med andre mer spesialiserte gruppetilbud eller selvhjelpsgrupper i regi av lokale frivillige og offentlige tjenester. ${ }^{13}$

Sist, men ikke minst inneholder det kommunale handlingsprogrammet et eget punkt om samarbeid med frivillig sektor og hvor det står at det skal arbeides med å: «... finne framtidige samhandlings- og samarbeidsområder mellom tredje sektor og kommunen» og vi kan videre lese at dette arbeidet: «... forutsetter gjennomgang og avklaring av grenseoppgang mellom offentlig ansvar og tredje sektors oppgaver».14 En allerede etablert arbeidsgruppe skal se på temaet, det anbefales en fast struktur for samarbeidet, og det presiseres at denne gruppen skal avklare hvilke kjerneoppgaver kommunen er ansvarlig for, hvilke kjerneoppgaver tredje sektor kan utføre, og hvilke oppgaver de kan samarbeide om.

Et interessant trekk ved det kommunale handlingsprogrammet er at den nasjonale selvhjelpssatsingen ikke nevnes sammen med gruppetilbud av etablerte fagteam eller frivillig sektor. Det ser altså ut som om handlingsprogrammet skiller mellom den nye nasjonale satsingen på selvhjelp, ved henvisning til Norsk selvhjelpsforum, og det allerede eksisterende selvhjelpsrelaterte arbeidet $\mathrm{i}$ byen $\mathrm{i}$ regi av spesialiserte faglige team, frivilligsentralen og brukerorganisasjonene. Dette kan være et strategisk grep for

\footnotetext{
11 Strategi- og økonomiplan 2010-2013. (Handlingsprogram, punktene 1-16, s 44-45).

12 Strategi-og økonomiplan 2010-2013. (Handlingsprogram, punkt 10, s. 45).

13 Frivilligsentralen er et nytt navn på tidligere frivillighetssentralen.

14 Strategi-ogøkonomiplan 2010-2013. (Handlingsprogram, punkt 15, s. 46).
} 
at det nasjonale kompetansesenteret ikke skal bli sett på som en trussel fra de lokale samarbeidspartnerne. ${ }^{15}$

Norsk selvhjelpsforum kan betraktes som en aktør som arbeider i grenseland mellom det offentlige og sivile samfunn. Forumet er en sivil aktør som samarbeider med offentlige myndigheter på nye måter og de legger til rette for prosesser omtalt som grensearbeid. Den nasjonale satsingen på selvhjelp kan oppfattes som et eksempel på slike blandingsformer (Feiring, 2019).

Norsk selvhjelpsforum baserer sitt arbeid primært på erfaringskunnskap selv om fagpersoner med bakgrunn i psykiatri og psykologi har vært sentrale støttespillere. De inngår samtidig i flere samarbeidsprosjekter med offentlige myndigheter, blant annet nasjonal plan, kompetansesenteret Selvhjelp Norge og selvhjelpsenteret LINK, som betjener hovedstadsområdet. Jeg vil si at det er nettopp på bakgrunn av denne form for grensearbeid i randsonen mellom det offentlige og det sivile, at selvhjelpsaktøren får med seg bykommunen i utformingen av et felles utviklingsarbeid.

Den nasjonale satsingen på selvhjelp får tidlig innflytelse på bykommunens handlingsprogram for helse- og omsorgstjenester. Selvhjelpsarbeid kommer på den lokalpolitiske dagsordenen som ett av flere tiltak i kommunens handlingsprogram. Kommunen omtaler selvhjelpsaktiviteter både i relasjon til egne helsetjenester og til eksisterende tiltak i regi av frivillige aktører og interkommunal samhandling.

\section{Lokalt samarbeidsforum for selvhjelpsarbeid}

I tillegg til tydelige spor av selvhjelpsaktørens informasjonsarbeid i kommunens planarbeid, har den nasjonale satsingen på selvhjelp også bidratt til nye arenaer for videre samarbeid. Om lag samtidig med at selvhjelpssaken blir satt på den lokalpolitiske dagsordenen, dannes et forum for samarbeid mellom representanter fra kommunen og den nasjonale selvhjelpsaktøren. Dette tiltaket er i tråd med handlingsplanens anbefaling om etablering av en arbeidsgruppe mellom kommunale og frivillige

15 Strategi- og økonomiplan 2010-2013. (Handlingsprogram, punktene 8, 10 og 15, s. 45-46) 
aktører, for å avklare grenseoppganger og framtidig samarbeid. En sentral oppgave er nettopp å utforme en avtale om arbeidsdeling for hvem som skulle ha ansvar for hva. En annen oppgave for samarbeidsforumet er å materialisere det nye samarbeidet i form av lokale og regionale arenaer for selvhjelpsarbeid.

Det videre samarbeidet mellom kommunen og selvhjelpsaktøren kan i denne fasen karakteriseres som forhandlinger. ${ }^{16}$ Det nasjonale kompetansesenteret tilbyr å etablere et regionalt kontor i byen som skulle betjene to fylker, dersom kommunen bidrar med utvikling av en lokal møteplass for selvhjelp overfor sine innbyggere. Videre, dersom kommunen skaffer lokaler, vil det nasjonale kompetansesenteret fortsette informasjons- og opplæringsarbeidet om selvhjelpsarbeid til de kommunale tjenestene og til lokalbefolkningen. En lokalavis omtaler etablering av det nasjonale kompetansesenterets distriktskontor slik:

Kontoret informerer om selvhjelp til blant annet kommuner, leger, pasientforeninger, skoler og arbeidsplasser. De skal hjelpe til med å sette i gang selvhjelpsgrupper og sørge for at de blir selvgående. En selvhjelpsgruppe kan være i regi av Kreftforeningen eller en rusorganisasjon. (Storvik, 2010, 2. november)

De to sosiale arenaene som materialiseres er: i) en regional koordinerings-, informasjons- og kunnskapsenhet for selvhjelpsarbeid i form av et distriktskontor under det nasjonale kompetansesenteret og ii) en lokal møteplass for selvhjelpsarbeid og selvhjelpsgrupper i samarbeid med lokale offentlige og frivillige tjenester, omtalt som et LINK. De er begge grenseobjekter og arenaer for grensearbeid.

Samtidig blir en formell arbeidsdeling mellom de to hovedaktørene utformet. Det nasjonale kompetansesenteret skulle bidra med kunnskap om selvhjelp og fungere som veileder og nasjonal samarbeidspartner. Dette arbeidet skulle ivaretas av distriktskontoret. Kommunen skulle være ansvarlig for å iverksette selvhjelpsarbeid i regi av egne tjenester samt bistå med lokaliteter og annen administrativ støtte. Bykommunens engasjement begrunnes med «erkjennelsen av at de offentlige tilbudene 
først og fremst skulle støtte opp under det enkelte individs egenomsorg». ${ }^{17}$ I en søknad om samhandlingsmidler til sentrale helsemyndigheter skriver kommunen at de er opptatt av å orientere seg mot nye arbeids- og samhandlingsmønstre, det er en krevende oppgave, og det er behov for å utvikle en ny selvforståelse i det offentlige hjelpesystemet. Samtidig presiserer kommunen at en ny selvforståelse må utvikles sammen med både tjenesteytere og mottakere. ${ }^{18}$

Utover de midlene som er bevilget til den nasjonale selvhjelpssatsingen, kommer det ikke flere økonomiske ressurser til det lokale samarbeidet fra statlige myndigheter. Det er bykommunen som tildeler prosjektmidler til en lokal arena, et LINK for selvhjelpsarbeid, og som utformer en samarbeidsavtale med Norsk selvhjelpsforum der det står:

Kommune[n] har tatt selvorganisert selvhjelp inn som et viktig element i sin økonomi- og strategiplan. Dette er videreført gjennom kommunestyrets budsjettvedtak for 2012, der det er avsatt kr 250.000 til etablering av en møteplass for selvorganisert selvhjelp i regionen. ... Målsettingen med etableringen av en nøytral møteplass for selvhjelp er å gjøre kunnskap om selvhjelp og selvorganiserte selvhjelpsgrupper tilgjengelige for befolkningen. ${ }^{19}$

Ifølge samarbeidsavtalen er kommunen tildelt ansvar for de organisatoriske og finansielle sidene, mens selvhjelpsaktøren skal bistå med informasjon og kompetanseformidling. Avtalen indikerer altså at bykommunen og selvhjelpsaktøren er relativt likestilte partnere som samtidig utfyller hverandre. Det nasjonale kompetansesenteret skal hovedsakelig arbeide med informasjonsformidling og kunnskapsoverføring for å skape en lokal forståelse for selvhjelpsarbeid. Samarbeidsforumet og den formaliserte avtalen mellom kommunen og Norsk selvhjelpsforum kan sees som rammefaktorer for samarbeidet, der det endelige produktet er å utvikle arenaer og nettverk for selvhjelpsarbeid lokalt.

\footnotetext{
17 Søknad om «samhandlingsmidler» sendt til Helsedirektoratet i 2011. Arkivmateriale

18 Søknad om «samhandlingsmidler» sendt til Helsedirektoratet i 2011. Arkivmateriale

19 Samarbeidsavtalen mellom Norsk selvhjelpsforum og bykommunen 17.02.2012. Arkivmateriale
} 


\section{En sammenligning av felles språkbruk i to planarbeider}

Det innledende samarbeidet mellom kommunen og selvhjelpsaktøren skjer $\mathrm{i}$ en periode der lokale myndigheter er opptatt av å tenke nytt $\mathrm{i}$ forhold til helse- og omsorgstjenestene. Kommunen er gjennom statlige føringer som samhandlingsreformen «pålagt» å finne nye tilnærminger og nye løsninger på framtidige utfordringer og problemer ved egne tjenester. En form for nyorientering av arbeidsformer er allerede i gang i de kommunale plan- og strategidokumentene. En av de kommunale representantene beskriver det slik:

Dette er veldig viktig og det dreier seg om to ting: Vi i kommunale tjenester klarer ikke å løse alle problemer for folk - tilbudet kan ikke ta mål av seg å gjøre det, og skal folk leve det gode liv så må folk ta et ansvar for det sjøl. Og dette står faktisk beskrevet i vår kommunedelplan omsorgstjenester på en sånn måte at folk må bli aktører i eget liv og at de kommunale pleie-, helse- og omsorgstjenestene står i fare for å ta fra folk ansvaret. (Kommunal aktør)

Selvhjelpsaktøren anvender samtidig en rekke politiske begrep i sine tekster. Ifølge Lundgren (2010) er Norsk selvhjelpsforums tekster sammenvevet med statlige helsepolitiske målsettinger, og har som siktemål å konstituere autonome og ansvarsfulle borgere. Det at tekster relaterer seg direkte eller indirekte til andre tekster, omtales av Fairclough (2003) som en form for intertekstualitet.

Jeg skal nå gjøre en kortfattet analyse av dialogen mellom den nasjonale selvhjelpsplanen for perioden 2004-2013 og den kommunale handlingsplanen for perioden 2010-2013. Hensikten er å identifisere bruk av samme ord og utsagn i de to planene, noe som i tekstanalysen omtales som manifest og konstituert intertekstualitet. Jeg har valgt ut fire strategiske utsagn fra den nasjonale selvhjelpsplanen fra 2004, de to første definerer selvhjelp som fenomen og metode, mens de to siste framhever sentrale begrep: forebygging og brukermedvirkning eller empowerment. Under hvert av utsagnene sammenligner jeg med strategisk utvalgte utsagn fra den kommunale handlingsplanen. 
(1) I nasjonal plan for selvhjelp (Sosial- og helsedirektoratet, 2004) står denne beskrivelsen av selvhjelp: ${ }^{20}$

Selvhjelp er å ta tak i egne muligheter, finne fram til egne ressurser, ta ansvar for livet sitt og selv styre det i den retning en ønsker. Selvhjelp er å sette $\mathrm{i}$ gang en prosess, fra passiv mottaker til aktiv deltaker i eget liv. (SP 2004-2013, s. 7)

Selv om dette er nedfelt i en nasjonal plan, utgitt av de nasjonale helsemyndighetene, oppfatter jeg utsagnet som Norsk selvhjelpsforums forståelse av selvhjelp. Dette presiseres i teksten der det står at utsagnet stammer fra Angstringen, og at det er sitert i Folkehelsemeldingen av 2003-2004 (Helse- og omsorgsdepartementet, 2003), noe som altså demonstrerer en manifest intertekstualitet med helsepolitiske dokumenter. Videre står det i nasjonal plan at selvhjelp: «er en arbeidsmetode hvor den enkelte motiveres til å ta i bruk egne ressurser for å sette seg selv i stand til å håndtere de belastninger en utsettes for» (SP 2004-2013, s. 8). Dette betyr at ordformuleringer som «å finne fram til egne ressurser» og «ta i bruk egne ressurser» er sentrale begrep som representerer selvhjelpsarbeidet og den nasjonale aktøren.

Dersom vi søker opp ordene «egne ressurser» i kommunens handlingsplan (2009, 26 august), finner vi denne formuleringen: «Legge forholdene til rette, slik at alle innbyggere kan benytte egne ressurser, oppleve uavhengighet og bidra til fellesskapet» (KP 2010-2013, s. 9). Dette kan tolkes som at de to planene kommuniserer med hverandre når det gjelder språkbruk, som at det enkelte menneske i større grad skal anvende «egne ressurser» for å løse sine livsproblemer. Ordbruken «egne ressurser» antyder at tekstene og utsagnene refererer til hverandre, og dette omtaler jeg som beslektet begrepsbruk - de to planene kan leses som om de er i dialog med hverandre. I kommunens handlingsplan brukes stort sett ordet «ressurs» om økonomisk eller personellmessige kapitalformer og ikke om det enkelte menneskets personlige ressurser. Slik sett er det mulig å anta at den personlige måten å snakke om ressurser på er en overføring

20 For å forenkle framstillingen i teksten viser jeg her til Nasjonal plan for selvhjelp (Sosialog helsedirektoratet, 2004) som (SP 2004-2013) og Kommunal handlingsprogram som (KP 2010-2013). 
av selvhjelpsvokabularet til kommunalt planarbeid. De første eksemplariske sitatene viser at begrepet «egne ressurser» brukes av begge planene, og at dette er begrepsbruk hentet fra en mer individualistisk og personlig språkbruk i tråd med selvhjelpstradisjonen snarere enn den politiske planretorikken.

(2) I nasjonal plan for selvhjelp (SP 2004-2013, s. 7) kan vi lese dette om hva den grunnleggende framgangsmåten ved selvhjelp kan lede til. Grunnprinsippene i selvhjelpsarbeidet, selvstendighet og evne til å mestre eget liv, kan gi økt livskvalitet og øke den enkeltes muligheter til å delta i samfunnet. Formuleringen «delta i samfunnet» kan også knyttes til det forrige sitatet fra den kommunale handlingsplanen «bidra til fellesskapet».

Vi kan samtidig finne bruk av ordet «mestring» i den lokalpolitiske handlingsplanen (KP 2010-2013, s. 18): «Kommunehelsetjenesten har et langt større fokus på pasientens funksjonsnivå og mestringsevne.» Videre har kommunen formulert som et hovedmål fram til 2021 at: «Innbyggerne opplever et tilgjengelig og høyt kvalifisert offentlig hjelpeapparat, enten behovet er behandling, bistand til mestring eller forebygging» (sitert i KP 2010-2013, s. 42). Ordet mestring er anvendt i begge plandokumentene, og mens selvhjelpsplanen kobler mestring til selvstendighet, livskvalitet og deltakelse i samfunnet, bruker den kommunale handlingsplanen også begrepet «mestringsevne» tilnærmet synonymt med «forebygging».

(3) De neste begrepene jeg vil framheve, er «brukermedvirkning» og «empowerment». Igjen knytter selvhjelpsplanen til politiske dokumenter og skriver følgende: «I arbeidet med Opptrappingsplanen for psykisk helse (1999-2008) legges det stor vekt på holdningsendring og brukermedvirkning» (SP 2004-2013, s. 7). I den nasjonale selvhjelpsplanen står det at: «Selvhjelp er rettet inn mot egenmestring og brukermedvirkning» (SP 2004-2013, s. 7). Videre kan vi lese «Det er snakk om en prosess som kan gjøre den enkelte bedre i stand til å identifisere og artikulere sitt problem, og med det skape grunnlag for å bedre egen livssituasjon. Denne egenkraftmobiliseringen benevnes internasjonalt som "empowerment"» (SP 2004-2013, s. 8).

Også i Europa har det blitt gjort mye utviklings- og forskningsarbeid omkring selvhjelp - noe som både definerer selvhjelpsarbeid og undersøker 
hvorledes selvhjelpsgrupper bidrar til egenmestring og empowermentprosesser.

(SP 2004-2013, s. 10)

Her knyttes først ordet «brukermedvirkning» til «egenmestring» og «empowerment». Vi kan lese at selvhjelp er en form for egenkraftmobilisering som internasjonalt omtales som «empowerment». I kommunens handlingsplan er ikke det engelske ordet «empowerment» anvendt, men «brukermedvirkning» er brukt én gang ved omtale av: «Utfordringer ved psykisk helsearbeid: Brukermedvirkning og brukerstyrte tiltak» (KP 2010-2013, s. 50). Dersom brukermedvirkning kan forståes som selvhjelp og ikke kun brukerstyrte tiltak, kan kommunen lettere lykkes i å innfri kravet om deltakelse fra brukere og befolkningen ved å igangsette selvhjelpsgrupper.

(4) De siste sitatene som jeg har trukket fram, viser til bruk av ordet «forebygging» eller «forebyggende» $\mathrm{i}$ de to plantekstene. I nasjonal plan for selvhjelp kan vi lese:

Selvhjelpsgrupper for mennesker [...] er virksomme i et helsefremmende og forebyggende perspektiv. (SP 2004-2013, s. 11)

I den kommunale planen er forebygging nevnt i tre ulike kontekster. For det første i forbindelse med samhandlingsreformen - omtalt som en kommunehelsereform: «Kommunenes rolle i den samlede helse- og omsorgspolitikken vurderes endret slik at de i større grad enn i dag kan oppfylle ambisjonene om forebygging og innsats i sykdoms-forløpenes tidlige faser» (KP 2010-2013, s. 18). Dernest er forebygging nevnt i forbindelse med sentrale utfordringer framover: «Det forebyggende aspektet må gjennomsyre tenkningen i alle faser av problem- og sykdomsforløpene. Forebygging og tidlig intervensjon kan være hovednøkkelen til løsningene i møtet med framtidas utfordringer» (KP 2010-2013, s. 42). Til sist brukes ordet forebygging om rettferdig fordeling av tjenester med henvisning til statlige dokumenter: «I statsbudsjettet ble det også pekt på at rettferdig fordeling ikke minst handler om bredde og samarbeid i det forebyggende arbeidet.»

Det å dreie helse- og omsorgstjenestene fra behandling til forebygging og forebyggende arbeid står sentralt i samhandlingsreformen (NOU 
2011:11, 2011). Samtidig er forebygging et eksempel på felles begrepsbruk i dialogen mellom de to planarbeidene.

Ordene egne ressurser og egenmestring er typiske begrep inspirert av den individualistiske og personsentrerte litteraturen, mens brukermedvirkning og forebygging er politiske og retoriske begrep. Det er derfor interessant at brukermedvirkning ikke er tydelig nedfelt i den kommunale planen. I den senere planen for selvhjelpsarbeid (SP 2014-2018), er verken ordet brukermedvirkning eller empowerment anvendt, mens forebyggende arbeid og iboende ressurser og mestring er sentrale begrep (Helsedirektoratet, 2014). Det kan altså se ut som om Norsk selvhjelpsforum er betydelig mer forsiktig med å anvende ordet brukermedvirkning i dag enn for 10-15 år siden. Dette temaet har jeg ikke anledning til å følge opp i denne studien.

Begge de to aktørene arbeider med utgangspunkt i plandokumenter; kommunen er opptatt av å etablere en ny selvforståelse og en ny helseog omsorgstjeneste, mens selvhjelpsaktøren bistår dem i dette arbeidet med sitt engasjement for en ny helseforståelse hos den enkelte borger. Videre er kommunen opptatt av nytenkning for å møte de nye statlige helsereformene (les: samhandlingsreformen), mens selvhjelpsaktøren støtter dem i dette arbeidet med en nasjonal satsing på selvhjelpsarbeid, der den enkelte tar en aktiv stilling til egne ressurser og egen mestring.

Denne sammenligningen av ordbruk $\mathrm{i}$ de to planarbeidene viser eksempler på intertekstualitet mellom den nasjonale selvhjelpslanen og den kommunale handlingsplanen for de framtidige helse- og omsorgstjenestene. Analysen av de eksemplariske tekstutdragene viser at de to hovedaktørene anvender beslektet begrepsbruk, noe vi kan fortolke som eksempler på grensearbeid og utvikling av samarbeid mellom to aktører som representerer relativt ulike sosiale verdener.

Jeg har undersøkt om selvhjelpsaktøren kan sees som del av en grensebevegelse som opererer innenfor et hybridiserte kulturelt system; og om det nasjonale kompetansesenteret og de lokale møteplassene for selvhjelp kan betraktes som grenseobjekt. Denne analysen har vist at utformingen av grenseobjekter skjer i et samvirke mellom sivilsamfun og kommunale aktører gjennom prosesser for oversettelser og forhandlinger og det 
som jeg her har betegnet som grensearbeid (Brown et al., 2004; Gieryn, 1983; Illouz, 2008; Star, 1987).

\section{Konklusjon}

I dette kapittelet har jeg studert en samarbeidsprosess om selvhjelpsaktiviteter mellom en nasjonal selvhjelpsaktør og en norsk bykommune. Analysen omhandler en flerfaset prosess om hvordan et offentlig-sivilt samarbeid initieres og forsøkes gjennomført i praksis. I den innledende fasen prioriterer selvhjelpsaktøren en bred informasjonsstrategi med den hensikt å få selvhjelpsaktiviteter politisk forankret i bykommunen. Informasjon om ulike former for selvhjelpsarbeid formidles til en rekke ulike aktører og oversettes inn i aktuelle politiske strategi- og plandokumenter. Informasjon om selvhjelp til kommunale politikere, tjenesteledere, tjenesteutøvere og til befolkningen for øvrig står på agendaen.

Deretter blir et samarbeidsforum mellom selvhjelpsaktøren og de kommunale tjenestelederne etablert. De møtes regelmessig for å utvikle en samarbeidsavtale mellom kommunens tjenesteledere og den nasjonale selvhjelpsaktøren. På dette stadiet er hovedtemaet forhandlinger om en arbeidsdeling samt et videre samarbeide om utforming av møtesteder for selvhjelpsaktiviteter i byregionen. Det forhandles om en felles forståelse av selvhjelp, felles bruk av lokaler og felles finansiering av de nye selvhjelpsaktivitetene.

Selvhjelpsaktørens tilbud var å etablere et distriktskontor for hele regionen lokalisert innenfor byens grenser, dersom kommunen tok ansvar for å etablere en lokal møteplass for selvhjelp for sine egne innbyggere. Et kriterium ved denne form for samarbeid er plastisitet og fleksibilitet, og dette undersøkes ved å se på hvordan aktørene arbeider for å utvikle en form for felles begrepsbruk. Jeg sammenligner hvordan representasjoner for selvhjelpsarbeidet oversettes fra nasjonal selvhjelpsplan til bykommunens handlingsplan for omsorgstjenester. Studien viser eksempler på felles bruk av ord som ressurser mestring og forebygging i den nasjonale selvhjelpslanen og det kommunale planarbeidet. 
Et kjennetegn ved komplekse samarbeidsprosesser er at de fungerer dersom aktørene skaper håndterbare felles prosjekt eller grenseobjekter som begge virksomhetene kan identifisere seg med. Den nasjonale satsingen på selvhjelpsaktiviteter og kommunens leting etter nye arbeidsmåter og samarbeidsformer innen helse- og omsorgstjenestene ser ut til å ha fungert som en randsone - for et slikt grensearbeid. I hvilken grad denne form for samarbeid mellom sivile og offentlige aktører består over tid, ser ut til å være et spørsmål om de klarer å opprettholde tilstrekkelig felles interesser og felles prosjekter og dermed de nødvendige rammefaktorene for et kontinuerlig grensearbeid.

\section{Referanser}

Bowker, G. C. \& Star, S. L. (200o). Sorting things out: Classification and its consequences. Cambridge, Mass.: MIT Press.

Brown, P., Zavestoski, S., McCormick, S., Mayer, B., Morello-Frosch, R. \& Gasior Altman, R. (2004). Embodied health movements. New approaches to social movements in health. Sociology of Health \& Illness, 26(1), 50-80.

Ernestus, E. (2009, 18 juni). Et positivt vågestykke. Lillehammer byAvis.

Fairclough, N. (1992). Intertextuality in critical discourse analysis. Linguistics and Education, 4(3), 269-293. https://doi.org/10.1016/o898-5898(92)90004-G

Fairclough, N. (2003). Analysing discourse: Textual analysis for social research. London: Routledge.

Feiring, M. (2013). Politicisation of self-help in Norway. I L. Nicolaou-Smokoviti, H. Sünker, J. Rozanova \& V. Pekka Economou (Red.), Citizenship and social development. Citizen participation and community involvement in social welfare and social policy. Frankfurt am Main: Peter Lang Publishing Groups.

Feiring, M. (2019). Selvhjelpsarbeid - mellom erfaringskunnskap og forskningsbasert kunnskap. I O. P. Askheim, I. M. Lid \& S. Østensjø (Red.), Samproduksjon i forskning. Oslo: Universitetsforlaget.

Gieryn, T. F. (1983). Boundary-work and the demarcation of science from nonscience: Strains and interests in professional ideologies of scientists. American Sociological Review, 48(6), 781-795. https://doi.org/10.2307/2095325

Gieryn, T. F. (1999). Cultural boundaries of science. Chicago: University of Chicago Press.

Gubrium, J. F. \& Holstein, J. A. (2009). Analyzing narrative reality. Los Angeles: Sage. 
Helse- og omsorgsdepartementet. (2003). Resept for et sunnere Norge: Folkehelsepolitikken. (St.meld. nr. 16 (2002-2003)). Oslo: Helse- og omsorgsdepartementet.

Helse- og omsorgsdepartementet. (2008). Samhandlingsreformen, Rett behandling - på rett sted - til rett tid (St.meld. nr. 47. (2008-2009)). Oslo: Helse- og omsorgsdepartementet.

Helsedirektoratet. (2014). Nasjonal plan for selvhjelp, IS-2168. Oslo: Helsedirektoratet. Hentet fra http://www.selvhjelp.no/filestore/NasjonalplanforselvhjelpIS-2168.pdf

Illouz, E. (2008). Saving the modern soul: Therapy, emotions, and culture of self-help. Berkeley: University of California Press.

Kommunedelplan omsorgstjenester 2009-2021. August 2009, Lillehammer kommune.

Lundgren, G. V. (2010). Självhjälpens retorik. En Foucaultinspirerad textanalys av Norsk Selvhjelpsforums introduktionshäfte selvhjelp - en innføring. Oslo: Universitet i Oslo.

Mæhre Vold L. M. (2009, 3. september). Bygge broer med selvhjelp. Lillehammer byAvis.

NOU 2011:11 (2011). Innovasjon i omsorg. Oslo: Helse- og omsorgsdepartementet.

Prior, L. (2003). Using documents in social research. London: Sage Publications.

Sosial- og helsedirektoratet. (2004). Nasjonal plan for selvhjelp, IS 1212. Oslo: Sosialog helsedirektoratet.

Star, S. L. (1987). The structure of ill-structured solutions: Boundary objects and heterogeneous distributed problem solving. I L. Gasser \& M. N. Hunhs (Red.), Distributed artificial intelligence (s. 387-420). London: Pitman Morgan Kaufmann.

Star, S. L. \& Griesemer, J. R. (1989). Institutional ecology, 'translations' and boundary objects: Amateurs and professionals in Berkeley's Museum of Vertebrate Zoology, 1907-39. Social Studies of Science, 19(3), 387-420. https://doi.org/10.2307/285080

Storvik, A.G (2010, 2. november). Det funker å snakke sammen. Gudbrandsdølen Dagningen.

Strategi- og økonomiplan 2010-2013. Handlingsprogram. Lillehammer kommune.

\section{Nettadresser}

http://www.selvhjelp.no/no/Tematisert/Selvhjelp_for_deg, lastet ned i desember 2012.

http://www.selvhjelp.no/filestore/IS-1212_3743a.pdf, lastet ned i juni 2009. http://www.selvhjelp.no/no/Distriktskontorer/Hedmark_og_Oppland/Hva_skjer+/, lastet ned i august 2013. http://www.komutprosjektet.no, lastet ned i september 2012 , 
http://www.trustprosjektet.no/; lastet ned i september 2012, http://www.Lillehammer.kommune.no/trust.4930591-188871.html, lastet ned i september 2012.

http://www.oyer.kommune.no/interkommunal-samhandlings-ogutviklingsenhet.5076761-172353.html;http://www.gausdal.kommune.no/cpclass/ run/cpesa62/file.php/pdf/12010822d120108220ee582d/organisatorisk-tilknytningav-interkommunal-samhandlings-og-utviklingsenhet.pdf, lastet ned i mai 2013. http://www.selvhjelp.no/no/Distriktskontorer/Hedmark_og_Oppland/Hva_skjer+/, lastet ned i august 2013.

http://www.selvhjelp.no/filestore/Rapport_2011_Hdir_HK_DK_endelig_120412.pdf, lastet ned i mai 2013.

http://www.selvhjelp.no/no/Om_oss/Nyheter/, lastet ned i mai 2013.

http://www.Lillehammer.frivillighet.no/aarsmelding.php, lastet ned i desember 2012. http://www.selvhjelp.no/no/Tematisert/Samfunnsperspektiv/Samfunn/L\%C3\%A6rin g,+mestring+og+selvorganisert+selvhjelp.b7C_wlnGZ7.ips, lastet ned i desember 2012.

\section{Arkivmateriale}

Invitasjon til informasjonsmøte, 2009, 16. juni

Invitasjon til informasjonsmøte, 2009, 16. juni

Informasjonsmateriell, 2011, lastet ned, 14. februar

Informasjonsmateriell, 2009, lastet ned 27. august

Samarbeidsavtalen mellom Norsk selvhjelpsforum og Lillehammer kommune (2012) 17. februar

Søknad om «samhandlingsmidler» sendt til Helsedirektoratet i 2011 



\title{
Rom for selvhjelp. Sosialt entreprenørskap og offentlig- frivillig samarbeid
}

\author{
Ånund Brottveit \\ KIFO - Institutt for kirke-, regions- og livssynsforskning
}

\begin{abstract}
This chapter describes and analyses how self-help in groups was introduced in a rural municipality in Northern Norway. The location has drawn national attention because local forces managed to establish a clearinghouse for self-help groups (LINK) based on Self-help Norway's principles at an early moment in the organization's history. The case of "Selvhjelpshuset LINK" is analyzed with theories of social entrepreneurship and social innovation and field-theory. The legacy of Selvhjelpshuset LINK may give us some lessons on the social entrepreneur's central role when it comes to introduce and implement social innovations, the potential for resource allocation - in terms of economic, social, cultural and symbolic capital. It also draws attention to the dynamics of collaboration between civil society actors and municipal and state government agents. A dimension that has been the focus for studies of new forms of governance.
\end{abstract}

Keywords: social entrepreneur(ship), social capital, field, social technology, implementation network, governance

\section{Innledning}

I dette kapittelet vil jeg se nærmere på hvordan selvhjelpsgrupper ble introdusert og fikk innpass i en mindre, rural kommune i Nord-Norge. Utgangspunktet var et spørsmål om hvorfor man lykkes i ett lokalsamfunn, mens det oppleves som nesten umulig et annet sted? Dette ledet meg videre til nye spørsmål om betydningen av sosialt entreprenørskap og betingelser for lokal sosial innovasjon på velferdsområdet (Førde \& Borch, 2010).

Sitering av dette kapittelet: Brottveit, Å. (2019). Rom for selvhjelp. Sosialt entreprenørskap og offentlig-frivillig samarbeid. I Å. Brottveit \& M. Feiring (Red.), Samarbeid om selvhjelp. En antologi om den nye selvhjelpsbevegelsen $i$ Norge (s. 139-165). Oslo: Cappelen Damm Akademisk. https://doi.org/10.23865/noasp.68.ch6

Lisens: CC BY 4.0 
Selvhjelpshuset LINK er et eksempel med overføringsverdi til andre lokalsamfunn når det gjelder hvilken rolle sosiale entreprenører ofte spiller i forbindelse med sosial innovasjon, hvordan implementeringsprosesser kan forstås i et felt-perspektiv, og hvordan denne formen for offentlig-frivillig samarbeid om folkehelse også kan sees som et eksempel på nye offentlige styringslogikker.

Hensikten med denne studien er å fokusere på allmenne utfordringer ved innovasjon og sosialt entreprenørskap i lokalsamfunn. Kapittelet vil også berøre spesielle utfordringer knyttet til å opprette selvhjelpsgrupper i små gjennomsiktige samfunn, men dette behandles mer inngående i et annet kapittel (se kapittel 2).

På lokalplanet er det viktig å forstå bedre hva slags «mekanismer» som kan utløses når «noe nytt» forsøkes implementert: Hva er årsaker til at et prosjekt møter motstand eller tvert imot får drahjelp? Jeg retter et særlig søkelys på potensielle interessekonflikter mellom lokale aktører. Bourdieus feltteori og kapitalbegrep kan fange inn de lokale prosessene (Bourdieu \& Wacquant, 1992; Broady, 1991). For å forstå disse prosessene er det viktig å belyse den sosiale entreprenørens evne til å mobilisere ulike former for kapital (ressurser).

\section{Metode}

Det empiriske materialet for dette kapittelet er innhentet i en undersøkelse av selvorganisert selvhjelp i lokalsamfunn i tidsrommet 2011-2013. Jeg intervjuet 12 nøkkelpersoner som representerte selvhjelpsfrivillige, fagpersoner, kommunale ledere og politikere. Jeg har også foretatt en dokumentanalyse av den lokale selvhjelpsorganisasjonens egne rapporter, brosjyrer og nettsider.

Prosjektlederens rapport (Vang, 2010) er en sentral empirisk kilde her fordi den inneholder en kronologisk fremstilling av en rekke møter, vedtak og konkrete skritt i prosessen frem mot etableringen av et lokalt selvhjelpshus (LINK) i kommunen. Denne rapporten gjengir også e-postutvekslinger, brev, møtereferater, folkemøte- og seminarinnbydelser. Rapporten er skrevet som en slags statusrapport og kvittering for benyttede prosjektmidler, men er også i sin detaljrikdom et slags arkiv 
for implementeringsprosessen. Rapportfremstillingens hovedtrekk har jeg kunnet sammenholde med intervjuene med andre nøkkelpersoner i kommunen.

Tabell: Intervjuer case-studie i kommunen.

\begin{tabular}{l|c|c|c|c}
\hline Intervjuer: & $\begin{array}{l}\text { Selvhjelpsfrivillig/ } \\
\text { Ansatt selvhj.org. }\end{array}$ & Fagperson & $\begin{array}{l}\text { Adm. leder, } \\
\text { politiker }\end{array}$ & Sum \\
\hline Kommunen & 1 & 3 & 5 & 9 \\
\hline Selvhjelp Norge & 3 & 0 & 0 & 3 \\
\hline Totalt antall intervjuer & 4 & 3 & 5 & 12 \\
\hline
\end{tabular}

*Ansatt ved distriktskontoret i Tromsø eller ved Selvhjelp Norges hovedkontor i Oslo.

Det er viktig å poengtere at informantene svært ofte hadde mer enn én rolle i forhold til prosjektet. De kunne være involvert som både foreningsaktive, lokalpolitikere og fagpersoner, noe som er et typisk kjennetegn ved mindre lokalsamfunn. I tillegg til intervjuer med selvhjelpsfrivillige og ansatte har jeg gjennomført intervjuer med gruppedeltakere. Jeg har også hatt kortere feltobservasjoner i kommunen og har kunnet observere prosjektleder, andre selvhjelpsfrivillige, gruppedeltakere og lokale nøkkelpersoner i interaksjon under møter og seminarer. Prosessen som analyseres i dette kapittelet foregikk imidlertid forut for mine besøk i kommunen og er derfor basert på skriftlige kilder og retrospektive intervjudata.

Jeg hadde ikke noen relasjon til stedet eller til selvhjelpsorganisasjonene på forhånd. Utvelgelsen av intervjupersoner i lokalsamfunnet skjedde i samarbeid med den lokale prosjektlederen. Jeg kunne selv velge ut og ta kontakt med fagpersoner, kommuneansatte, foreningsledere og politikere, men gruppedeltakere og støttespillere i prosjektlederens sosiale nettverk uten formelle posisjoner ble forespurt gjennom prosjektlederen - i tråd med god forskningsetikk og krav fra Personvernombudet. Prosjektlederen omtales heretter stort sett som «entreprenøren», i sitatene er personnavnet byttet ut med «NN» og kommunens navn med «X kommune».

\section{Analytisk tilnærming}

Norsk selvhjelpsforum hadde på 200o-tallet begynt å definere selvhjelpsgrupper innenfor et «folkehelseperspektiv», og ønsket med dette 
å fokusere på allmenn forebygging og understreke at samtalegrupper ikke bare var for mennesker med rusproblemer eller psykiske lidelser. Staten hadde i samme tidsrom oppfordret befolkningen om å ta mer ansvar for egen helse og de frivillige organisasjonene til mer samarbeid om velferdsutfordringene (Helse- og omsorgsdepartementet, 2013; Helsedepartementet, 2003). Dette kom blant annet til uttrykk som «den andre samhandlingsreformen» (Helse- og omsorgsdepartementet, 2011). Ved å gjøre «folkehelse» til et sentralt nøkkelord og legge hovedaktiviteten inn i det statsfinansierte prosjektet Selvhjelp Norge tilpasset Norsk selvhjelpsforum seg til de endrede politiske betingelsene.

Signalene om at befolkningen må ta mer ansvar for egen helse gjennom sine livsstilsvalg, sammen med en sterk samarbeidsinvitasjon til den frivillige sektoren, faller inn i en generell utviklingstrend i de vestlige velferdsstatene. Den nye styringsideologien har blitt kalt governmentality og dens virkemåte governance (Dean, 2006; Rose, 2006). Jeg forstår «governance' som en «myk» form for styring gjennom frivillig samarbeid fra organisasjoner og enkeltindivider som internaliserer og tar ansvar for myndighetenes målsettinger. Governance-teoretikere betrakter ikke dette samarbeidet og ansvarsdelegeringen som en ensidig manipulasjon fra oven, men som en form for «samstyring» (Vabo \& Røiseland, 2008). Krefter i sivilsamfunnet kan opptre som aktører og oppnå innflytelse nedenfra gjennom sosialt entreprenørskap.

Entreprenør-begrepet har blitt brukt om lokale initiativtakere og «ildsjeler» som på ulike måter er innovative og som gjør en forskjell i samfunnsmessig forstand (Barth, 1967, 1972; Førde \& Borch, 2010; Nyseth \& Aarsæther, 2013). Sosialt entreprenørskap kalles av og til samfunnsentreprenørskap, men det er i begge tilfeller en betoning av et samfunnsnyttig formål:

Sosialt entreprenørskap defineres til å identifisere et problem i samfunnet, som man søker å løse eller forbedre. Man gjør dette på en ny, innovativ måte, og ofte ved å starte en organisasjon eller bedrift. (Ingstad, 2009)

Sosialt entreprenørskap kan også springe ut av det man innenfor selvhjelpsbevegelsen kaller «selvhjelpsfrivillighet». Den lokale sosiale entreprenøren i kommunen har etter egen oppfatning en adekvat «løsning», 
i dette tilfellet et selvhjelpssenter, men må overbevise andre om hva problemet består i. Det er her entreprenørens prosjekt begynner. Kapittelet vil vise at sosialt entreprenørskap i større grad handler om hvordan man håndterer den vanskelige implementeringsprosessen, og i mindre grad dreier seg om hvor genial ideen var. Men utgangspunktet vil ofte være at entreprenøren har identifisert et problem som andre ikke har sett.

Prosessuelle studier av sosialt entreprenørskap og sosial innovasjon (Førde \& Borch, 2010; Førde, Kramvig, Gunnerud \& Dale, 2013) viser at et samarbeid mellom flere lokale aktører, som er ulikt posisjonert, er nødvendig. For å drive prosjektet fremover er entreprenøren avhengig av «gode hjelpere» (Borch \& Vestrum, 2010), og dette «iverksettelsesnettverket» (Røiseland, 1999) må fylle en rekke ulike roller og skaffe tilgang til nødvendige ressurser. I tillegg er myndighetenes rolle viktig, noe som peker tilbake på samstyringsmodellen.

Spørsmål en stiller seg når en studerer et innovativt prosjekt som Selvhjelpshuset LINK, kan være følgende: Hva ble gjort i kommunen for å etablere et selvhjelpshus der - hvordan gikk man frem for å få den nødvendige støtten fra folk i maktposisjoner? Hva ble gjort for å spre informasjon til befolkningen om en utradisjonell måte å takle personlige utfordringer på, og for å skape et samarbeidslag som fikk dette «opp å stå» i et lite lokalsamfunn nordpå?

Hvordan kan vi forstå dynamikken i de interne relasjonene mellom selvhjelpsprosjektet og andre aktører i kommunen som forholder seg til den samme målgruppen? Dersom vi definerer alle aktørene som et lokalt helse- og velferdsfelt, kan vi undersøke dette samspillet ved hjelp av Bourdieus felt-teori.

Et felt er et system av aktører som kjemper om posisjoner innenfor et område hvor de forstår spillereglene og strever etter de samme godene, ifølge Bordieu. Hans felt-teori hevder at det ofte vil være et konkurranseforhold mellom ulike aktører innenfor et felt, og at staten også kan ha en regulerende rolle og påvirke «spillereglene» (Bourdieu \& Wacquant, 1992). En «nykommer» på feltet vil ofte oppfattes som forstyrrende for de som er der fra før, og risikerer forsøk på å bli utdefinert (Fligstein \& McAdam, 2010). For eksempel kan helsetjenestepersonell stille spørsmål ved at psykiatriske pasienter går i samtalegrupper uten en behandler og dermed 
stemple dette tiltaket som illegitimt. Kampen om å etablere en ny virksomhet må derfor sees i sammenheng med og i relasjon til de andre aktørene som opererer i det samme feltet. Slike prosesser kan analyseres med Bourdieus kapitalbegrep - altså ved å analysere kampen om posisjoner som en kamp om å allokere ulike typer kapital. Økonomisk kapital, i form av materielle ressurser, er ikke den eneste formen for kapital som leder til makt eller avmakt innenfor et felt. Bourdieu bruker begrepet sosial kapital for å betegne nettverksressurser, nyttige kontakter, informasjonstilgang, kommunikasjonskanaler og omdømme. Bourdieu bruker også betegnelsen kulturell kapital om kunnskap, språk og evne til å mestre sosiale koder og etikette. Kulturell kapital vil ofte dreie seg om kompetanse, både formell kompetanse og ulike former for erfaringskunnskap. Symbolsk kapital dreier seg om sosial anerkjennelse, omdømme, legitimitet eller ære. Aktørene innenfor feltet definerer hva slags ressurser som er gyldige innenfor de ulike kapitalformene, og dersom staten er involvert som en aktør, kan den ha en overordnet definisjonsmakt.

Ved hjelp av Bourdieus felt-teori vil jeg undersøke hvordan entreprenøren rent konkret arbeidet for å realisere prosjektet om et selvhjelpshus i kommunen. Hva er avgjørende for om et prosjekt lykkes eller ikke? Kan en mer inngående analyse av prosessen, betraktet som en form for ressursmobilisering i henhold til Bourdieus kapitalformer, gi oss bedre forståelse? Kan en analyse av prosessene som ledet frem mot selvhjelpssenteret $i$ kommunen, samtidig gi oss innsikt i hva sosialt entreprenørskap i praksis handler om? Som en innledning til behandlingen av slike spørsmål vil jeg i neste avsnitt gi et kort riss av prosjekt LINKs utviklingshistorie.

\section{Hvordan fikk Selvhjelpshuset LINK gjennomslag i en liten kommune?}

Prosjekt Selvhjelpshuset LINK ble startet i 2006 etter initiativ fra leder for Angstringen Nord, som hadde egen erfaring med grupper, både som deltaker og igangsetter av grupper. Entreprenøren ønsket å spre kunnskap om selvorganiserte selvhjelpsgrupper i sin hjemkommune. To år senere, vinteren 2008, ble Stiftelsen Selvhjelpshuset LINK opprettet og sikret kommunal driftsstøtte med entreprenøren som deltidsansatt. 
Det ble igangsatt flere grupper med fast møtepunkt i lokalene og hele tiden drevet et aktivt informasjonsarbeid. Selvhjelpshuset LINK har gjennom en drøy ti-årsperiode bidratt til å starte opp og huse lokale grupper, formidlet informasjon om selvhjelp og arrangert seminarer for tjenesteytere og andre interesserte. Her skal vi imidlertid se nærmere på prosessen som ledet frem til etableringen av selvhjelpshuset. Fremstillingen er, som nevnt ovenfor, i stor grad basert på prosjektrapporten til prosjektlederen/ entreprenøren, men den er på viktige punkter bekreftet gjennom intervjuer med entreprenøren, leder i Norsk selvhjelpsforum, den tidligere rådmannen og andre ansatte $i$ kommunen.

Entreprenøren tok i begynnelsen av 2006 kontakt med kommunen for å søke støtte for sine ideer om å etablere et LINK, men fikk i første omgang ingen støtte. Entreprenøren visste at det fantes muligheter til å søke statlige prosjektmidler. I forbindelse med opptrappingsplanen for psykisk helse hadde Helse- og sosialdirektoratet utlyst midler til selvhjelpsprosjekter. Direktoratet hadde også fått en ny Nasjonal plan for selvhjelp (Helsedirektoratet, 2004) som understreket betydningen av selvhjelp i grupper. Entreprenøren hadde kontakter i Norsk selvhjelpsforum og denne Oslo-baserte stiftelsens prosjektorganisasjon Selvhjelp Norge. Leder i Norsk selvhjelpsforum/Selvhjelp Norge ble i fortsettelsen en nær rådgiver for den lokale entreprenøren. Et råd var å ta direkte kontakt med kommunens rådmann for å be om støtte i prosessen videre. Rådmannen stilte seg positiv til initiativet, noe som medførte at det ble utarbeidet en søknad basert på et samarbeid mellom kommunen og Selvhjelp Norge.

Målsettingen med prosjektet ble formulert slik:

Å etablere et nøytralt treffsted i X kommune, for å gjøre informasjon og igangsetting av selvhjelpsgrupper tilgjengelig for menneskene i X kommune, på tvers av diagnoser og problemer. (Vang, 2010, s. 11)

Kommunen hadde lovet å skaffe lokaler og innredning. Da direktoratet innvilget søknaden, gikk prosjekt Selvhjelpshuset LINK inn i en ny fase. I løpet av en prosjektperiode på to år måtte de gjøre selvhjelpssenteret kjent i befolkningen og ikke minst hos aktuelle målgrupper, og de måtte rekruttere deltakere til selvhjelpsgrupper basert på Selvhjelp Norges modell (se kapittel 2). 
Entreprenøren var, som nevnt, selv aktiv innenfor Angstringen og hadde gjennom denne organisasjonen tidligere arbeidet for etablering av telefonbaserte selvhjelpsgrupper i Nord-Norge. I kommunen var det imidlertid ikke noen tradisjon for lokale selvhjelpsgrupper. Denne kommunen var slik sett i en situasjon som kan minne om mange andre norske lokalsamfunn. Selvhjelpsgrupper for mennesker som av ulike grunner kommer i en akutt livskrise eller som sliter med langvarige problemer knyttet til kronisk sykdom, sosiale belastninger eller traumatiske erfaringer, er ikke noe nytt i seg selv. I denne lokale konteksten kan selvhjelpsgrupper likevel karakteriseres som en sosial innovasjon, fordi man ikke hadde noen tradisjon for det. Når dette i tillegg ble lansert som grupper "på tvers» av ulike diagnoser og problemtyper, kan det ha virket enda mer ukjent for befolkningen. Dersom man hadde hørt om selvhjelpsgrupper fra før, var det større sjanse for at man hadde hørt om grupper for kreftrammede eller alkoholavhengige. Norsk selvhjelpsforum / Selvhjelp Norge hadde på dette tidspunktet lagd mye informasjonsmateriell om slike grupper, men det var en utfordring å skulle formidle dette i kommunen - og vinne tillit i befolkningen.

Rådmannen hadde blitt en viktig støttespiller på rådhuset og opp mot lokalpolitikerne, men det var også svært viktig å vinne gehør hos fagpersoner ansatt i sosialtjenesten og helsetjenestene. Innflyttingen i de kommunale lokalene og driftsstøtten betød ikke at kampen var vunnet. På mange måter var det nå den virkelige kampen begynte.

Informasjonsarbeidet måtte rette seg mot befolkningen og mot spesielle målgrupper via sosial- og helsetjenestene, for eksempel gjennom avisoppslag, internett, plakater og brosjyrer. Det kunne være avgjørende at Selvhjelpshuset LINK fikk legge ut brosjyrer på NAV-kontoret og at leger, psykologer, sosionomer og andre tjenesteytere ville tipse sine klienter om muligheten for å begynne i ei selvhjelpsgruppe. Kommunens mange frivillige foreninger var en annen arena for informasjonsspredning og derfor viktig å få med på laget.

For å komme videre med målsettingen om et LINK måtte det drives mer nettverksbygging. Informasjonsarbeidet overfor personer i administrative og faglige stillinger og lokalpolitikere hadde på mange måter en dobbelt målsetting: å gi folk i nøkkelposisjoner mer kunnskap om hva 
selvhjelpsarbeid er og hvilket behov det er for grupper, og å skaffe seg støttespillere og motvirke at det ble skapt motstandere.

Entreprenøren beskriver samarbeidet med kommunen slik:

Vi har jobbet tett sammen med kommuneledelsen i X. Vi har, som NN (leder for Norsk selvhjelpsforum) sa en gang, arbeidet sammen med kommunen både forlengs og baklengs, og har bygget opp et godt samarbeidsforhold til ledelsen i $\mathrm{X}$ kommune. Gode menneskelige relasjoner er viktig i selvhjelpsarbeid, uansett hvem vi er og hvilken rolle vi til enhver tid har i praksis. (Vang, 2010, s. 21)

Neste skritt var å invitere inn «mulige interesserte samarbeidspartnere» (Vang, 2010, s. 21) til et arbeidsseminar. Alle som ble betraktet som potensielle samarbeidspartnere - «en bredest mulig målgruppe av mennesker i organisasjoner og nettverk» (Vang, 2010, s. 21) - ble personlig kontaktet før invitasjonsbrevet ble sendt ut. Folkehelsekoordinatoren i kommunen sørget for at entreprenøren fikk komme på et fagmøte for helsepersonell og informere om prosjektet og det planlagte arbeidsseminaret. Kommunelegen gikk i møtet god for dette og legitimerte at de kunne prioritere tid til seminaret. Flere hadde behov for å diskutere spørsmål om taushetsplikt, noe det ble gitt rom for.

Arbeidsseminaret hadde innlegg ifra kommunens varaordfører, mens selvhjelpsorganisasjonene var representert ved representanter fra LINK Oslo og Norsk selvhjelpsforum. I tillegg hadde én ifra Helse- og sosialdirektoratet et innlegg. De eksterne bidragsyterne kan ha vært viktige for å legitimere prosjektet overfor befolkningen og fagmiljøene. Arbeidsseminaret 14. september 2006 markerte samtidig den formelle åpningen av Selvhjelpshuset LINK.

Seminaret hadde 50 deltakere. Blant lokale tjenesteutøvere finner vi: ergoterapeut, psykiatriske sykepleiere, kommunelege, helsesøster, kulturkonsulent, personalansvarlig i kommunen, skolefaglig ansvarlig, bibliotekar, barnehageleder, sosialleder, flyktningkoordinator, folkehelsekoordinator, daglig leder for dagsenteret (psykisk helsearbeid), tannlege, trygdekontoret. Det kom også representanter for regionale tjenester og frivillige organisasjoner i nabokommuner eller på regionalt nivå, som Bikuben brukerstyrt senter, rådgiver hos fylkesmannen i Troms, diakoniutvalget, enkelte bygdeutvalg, Pensjonistforeningen, organisasjonen 
Pårørende til spillavhengige (PTS), Hørselshemmedes forbund, Afasiforeningen, Mental Helse, Angstringen Alta, Landsforeningen for hjerte- og lungesyke (LHL), Sanitetsforeningen og Husflidslaget (Vang, 2010, s. 31).

Nettverksarbeidet har også vært viktig i forhold til å få pressen interessert i prosjektet. Entreprenøren forteller om hvordan hun ble tipset om å gå via ordføreren og varaordføreren som gjennom Arbeiderpartiet hadde gode kontakter i A-pressen. Slik fikk entreprenøren kontakt med en journalist i avisa Nordlys, som lagde en reportasje om prosjektet der både varaordfører, folkehelsekoordinator og entreprenøren ble intervjuet. Entreprenøren fikk også et samarbeid med lokalavisa Framtid i Nord, som har kontor ved kommunesenteret, om dekning av fremtidige aktiviteter og annonsekjøp. NRKs distriktskontor lagde også en reportasje om arbeidsseminaret og åpningen. Lokalbefolkningen fikk se tv-bilder fra den forventningsfulle entreprenøren i frisørstolen noen timer før det braket løs, og senere fra selve seminaret.

Den brede oppslutningen om arbeidsseminaret, deltakelsen fra sentrale lokalpolitikere og utsendingene fra den nasjonale selvhjelpsorganisasjonen og Helse- og sosialdirektoratet gjorde at Selvhjelpshuset LINK fikk den åpningen som entreprenøren hadde ønsket seg. Mediedekningen gjorde antakelig det nye selvhjelpssenteret kjent i brede lag av befolkningen. Selv konstaterte entreprenøren at: «Media har vist seg å være en viktig samarbeidspartner og nødvendig aktør i markedsføring og informasjonsarbeidet» (Vang, 2010, s. 30).

I ettertid sier den daværende rådmannen at han alltid har hatt troen på idéen bak selvhjelpsgruppene, men det at det kom foredragsholdere fra Oslo, betydde mye for å få gjennomslag lokalt:

Det at NN var der som pådriver, var engasjert og fikk folk med seg ... Det er avhengig av «ildsjeler»! Det er også viktig at kommunen støtter - både økonomisk og moralsk. Viktig! NN var en sånn «ildsjel»! Og så er det bra at det var sentrale støttespillere med også, slike som lederen for Norsk selvhjelpsforum. En dyktig person som kom og holdt foredrag. Det betydde nok også mye for de profesjonelle helsetjenestene. Det bidro til å få litt gjennombrudd der, selv om jeg er litt usikker på status nå. (intervju) 
Den tidligere rådmannen beskriver, i likhet med entreprenøren, de lokale helsearbeiderne som delvis avventende og litt skeptiske. Det ville vært svært vanskelig, kanskje umulig, for entreprenøren å overbevise fagmiljøene uten å ha et solid lag av støttespillere i ryggen. En viktig alliert i så måte ble kommunens folkehelsekoordinator - en stilling som ble innført i forbindelse med den nasjonale satsingen på folkehelse.

Entreprenøren sier at det er innenfor fagmiljøene at hun har merket mest skepsis, og muligens også litt motstand, mot selvhjelpsidéen. Entreprenøren mener at dette kan bero på misforståelser blant enkelte fagpersoner som frykter at selvhjelpsgruppene rekrutterer psykisk syke mennesker som kan bli dårligere av gruppeprosesser uten profesjonelle ledere.

Da jeg intervjuet fagpersoner i kommunen i 2011 og 2012, var det ingen som argumenterte mot Selvhjelpshuset LINK eller verdien av selvhjelpsgrupper. Det er vanskelig å si hvorfor informantene uttaler seg positivt i intervjuene, når både entreprenøren og andre lokale pådrivere for selvhjelpsgrupper har opplevd å møte motstand i fagmiljøene. Det kan ha noe med tidspunktet å gjøre, at tiden har arbeidet for Selvhjelpshuset LINK og at selvhjelpskonseptet på den tiden intervjuene ble gjort, var mer allment godtatt - også i fagmiljøer som tidligere var mer skeptiske. En annen mulighet er at informantene underkommuniserer sin egen skepsis i intervjuene. Prosjektet hadde blitt støttet finansielt av direktoratet, og eksperter fra Oslo hadde kommet til kommunen og gitt entreprenøren støtte. Det vil uansett fortelle noe om hva som oppfattes som de mest «stuerene» (hegemoniske) oppfatninger av selvhjelpsgrupper i kommunen på denne tiden. At ingen av de intervjuede fagpersonene ville «flagge» direkte motstand, indikerer at informasjonskampanjene har fătt et visst gjennomslag. Samtidig kan den motstanden som entreprenøren fornemmet, bety at den symbolske kampen om Selvhjelpshuset LINKs omdømme ikke var vunnet en gang for alle.

Neste skritt var å invitere enkeltpersoner og frivillige organisasjoner til å møte opp på tirsdagskvelder for å dele erfaringer, få mer informasjon og vurdere eget behov for selvhjelpsgruppe (Vang, 2010, s. 35). Det ble satt inn gjentatte annonser i lokalavisene, og det kom 10-20 personer hver tirsdag. Det var tydelig at de som kom satte pris på å få et treffested, men det resulterte ikke i noen selvhjelpsgruppe. Etter en måneds tid trakk 
entreprenøren en konklusjon om at dette var blitt noe annet enn det som var intensjonen med selvhjelpssenteret.

Folk som egentlig ikke hadde tenkt å begynne med selvhjelp, eller som ville gå i selvhjelpsgrupper kom. De var de samme som kom, de ønsket seg en sosial møteplass hvor de kunne møtes for å drikke kaffe og snakke med hverandre. Ut fra min egen opplevelse tenkte jeg at noe ikke stemte. Var dette meningen med møteplassen? (Vang, 2010, s. 36)

Selvhjelpshuset LINK annonserte nå et nytt møte, denne gangen et «åpent folkemøte» som skulle oppsummere «erfaringer fra Selvhjelpshuset LINK frem til nå» og dessuten få en kommentar fra leder i Norsk selvhjelpsforum / Selvhjelp Norge. Konklusjonen på møtet ble formidlet gjennom overskriften i en avisreportasje i lokalavisa: «Du må ha et problem» (Nilsen, 2006). Beskjeden heretter var at selvhjelpssenteret ikke var et sted man skulle gå for å være sosial og drikke kaffe, men et sted man søkte til dersom man erkjente at man hadde et problem og kunne vurdere å begynne i ei selvhjelpsgruppe. Dette medførte at færre kom til senteret på tirsdagskveldene, men også at den første selvhjelpsgruppa ble startet på slutten av 2006.

Det fremgår av prosjektrapporten at det ble gjort mye informasjonsarbeid overfor befolkningen, overfor kommunale tjenester, mot politikerne og til de frivillige foreningene. Entreprenøren utviklet ved hjelp av eksterne konsulenter og et lokalt trykkeri en informasjonsbrosjyre og en nettside. Hun inviterte seg inn i fagseminarer på arbeidsplasser i kommunen og lokale foreningsmøter. Annonser ble satt inn i avisene, og kommunens eget informasjonsblad informerte om Selvhjelpshuset LINK (Vang, 2010).

Lokalpolitikerne ble kontaktet og oppfordret til å skrive selvhjelpsarbeid inn i kommunale helsetjenesteplaner. Sommeren 2017 ble det også opprettet ei arbeidsgruppe som skulle fungere som ei referansegruppe for Prosjekt LINK og videreutvikle prosjektet. Høsten 2007 ble det nødvendig å tenke på hvordan driften skulle videreføres når prosjektmidlene tok slutt i 2008. Konklusjonen ble å søke kommunen om støtte til å opprette selvhjelpssenteret som en egen stiftelse med kommunale driftsmidler (Vang, 2010). 
Tanken om å etablere en stiftelse, ble spredt gjennom lobbyvirksomhet i det politiske miljøet i forkant av kommunestyremøtet den 20.12.07. Framtid i Nord skrev om saken slik at alle politikerne skulle være forberedt, men fremdeles hadde ikke saken plass på sakslista til kommunestyret ... (Vang, 2010, s. 64)

Entreprenøren fikk en av politikerne til å reise saken i form av en interpellasjon på kommunestyremøtet. Politikeren forklarer senere at:

Jeg lagde 1 1⁄2 side, der jeg skrev om selvhjelpsforståelsen og arbeidet som var blitt gjort, og refererte til hva Dørum (tidligere statsråd) hadde sagt. Han sa at frivillighet var et supplement til det offentlige. (intervju)

Kommunepolitikerne ga positiv respons og ba administrasjonen om å se nærmere på søknaden som var blitt sendt. To måneder senere ble det vedtatt å gi stiftelseskapital og en årlig driftsstøtte. Dermed ble Selvhjelpshuset LINK etablert som stiftelse og sikret fast driftstøtte fra februar 2008.

Ordføreren fra den gang sier at han på et tidlig tidspunkt hadde tro på prosjektet, men at det var svært viktig at hun fikk en del sentrale støttespillere med på laget:

At hun også fikk mange sentrale personer med som jobbet i lag med henne. (...)

Du kan ha gode tanker og ønske om å starte noe som er bra, men det offentlige byråkratiet kan være tungt å komme gjennom (...). I det her tilfellet tror jeg at det var de riktige personene som ble med. Det var blant annet hun som var tidligere varaordfører og ... og ei som ledet levekårsutvalget, ... og jeg var også med å støtte dette her og ... (intervju)

Selvhjelpshuset LINK ble tilknyttet det landsomfattende nettverket til Selvhjelp Norge og denne organisasjonens Distriktskontor for NordNorge. Entreprenøren fikk en fast 20 \% stilling som daglig leder i det nye selvhjelpssenteret.

\section{Sosialt entreprenørskap og ressursallokering}

Kommunen er et lokalsamfunn som kan beskrives som sammensatt av flere felt. Jeg har nevnt det lokale helse- og velferdsfeltet som en særlig 
relevant avgrensning, men også at vi også kan betrakte forenings- og organisasjonslivet som et mulig felt. De religiøse institusjonene og organisasjonene kan være et annet aktuelt felt. Feltteorien gjør det mulig å analysere motstand og rivalisering, spesielt når det introduseres en «nykommer» i feltet. De som er der fra før, vil kunne betrakte nykommeren som en trussel mot sine egne interesser og posisjoner, kanskje endog mot sin egen eksistens (Broady, 1991). Men muligheten for samarbeid og arbeidsdeling er selvsagt også til stede. Bourdieu beskriver kampen for å bedre sin egen posisjon $i$ et felt, som en streben etter å allokere ressurser som har verdi innenfor feltet, ressurser i form av ulike former for kapital (Bourdieu \& Wacquant, 1992).

\section{Nykommer i feltet}

Kommunen tok på seg rollen som samarbeidspartner i prosjektsøknaden til Helse- og sosialdirektoratet. Rådmannen spilte en aktiv pådriverrolle internt $\mathrm{i}$ administrasjonen og overfor politikerne. I prosjektrapporten gjengis en e-post fra rådmannen til etatslederne hvor han beskriver selvhjelpsgrupper som «et godt supplement til våre ordinære tjenester» og prosjektet som en sjanse til å bli «en pilotkommune» (Vang, 2010, s. 14).

Kommunen har bare 3200 innbyggere. Ikke bare kjenner de fleste aktørene hverandre på et mer uformelt og personlig plan, mange har også dobbelt- og trippelroller i lokalsamfunnet. Politikerne kan ha administrative stillinger i kommunen og i tillegg sentrale verv i frivillige organisasjoner. I den lokale politiske virkeligheten kan dette selvsagt slå begge veier: Muligheten til å trenere en beslutning kan være større, men sjansen til å få flere aktører til å dra i samme retning kan også være større.

Den lokale prosjektlederen kan beskrives som en sosial entreprenør for selvhjelpssaken i kommunen. Fokuset i dette eksempelet er dynamikken mellom entreprenøren og den lokale konteksten - forstått som sosiale felt.

Etableringen av Selvhjelpshuset LINK - et møtested, informasjonssenter og formidlingssentral for lederløse selvhjelpsgrupper i et lite lokalsamfunn - kan fortelle oss noe generelt om betingelser for sosialt entreprenørskap. Sosialt entreprenørskap betegner en innovativ virksomhet; 
«nyskapingsaktiviteter som er retta mot å skape nye verdier og goder for samfunnet som helhet» (Førde \& Borch, 2010, s. 17).

I analyser av endringsprosesser i lokalsamfunn som har tatt utgangspunkt i entreprenørskapsbegrepet, har betydningen av den lokale «ildsjelen», og denne enkeltpersonens ressurser i form av sitt sosiale nettverk, blitt sterkt vektlagt (Førde \& Borch, 2010). Det har vært en diskusjon rundt betydningen av lokal kultur - om dette primært er en hemmende faktor for innovasjon, eller om kulturelle forutsetninger også kan spille en positiv rolle. Førde og Borch har en positiv tilnærming til kulturdimensjonen og skriver:

I følge Lavoie (1991) handler entreprenørskap, det å oppdage nye muligheter, om kulturell fortolkning, det handler om å kunne lese komplekse situasjoner og bidra i lokale diskurser. Og det er kultur som gjør aktører i stand til å lese disse situasjonene. (Borch \& Førde, 2010, s. 19)

Som det antydes i sitatet ovenfor, så er det ikke tilstrekkelig å ha en god idé, man må også kunne manøvrere gjennom det relativt uoversiktlige farvannet som ethvert norsk lokalsamfunn er. Den lokale konteksten må «leses», men den må også håndteres i nært samarbeid med de støttespillerne man har lykkes i å få med på laget. Det er en krevende og mangefasettert prosess å skaffe til veie de nødvendige tilgangene til økonomisk, sosial, kulturell og symbolsk kapital for at prosjektet kan bli levedyktig.

Likegyldighet, mistro og motstand er kjente fenomener i forbindelse med sosialt entreprenørskap, og det kan bunne i sammensatte årsaker. Feltperspektivet kan hjelpe oss her. En årsak til motstand kan være opplevd konkurranse om et «marked». Vi kan tenke oss en situasjon der en aktør har vært alene om å ha ansvaret for en bestemt oppgave eller målgruppe - relativt uforstyrret av andre aktører. Dersom en helt ny aktør kommer inn i bildet, vil det skapes en uavklart situasjon og potensiell trussel om å bli utkonkurrert, eller i det minste å måtte endre sin egen tilpasning. Nykommeren kan, på sin side, sette spørsmålstegn ved den etablerte organisasjonens opplevde eller reelle «monopol».

Idéen om et LINK ble ikke umiddelbart mottatt med åpne armer. Kravet om konkrete samarbeidsrelasjoner som ble rettet til andre lokale aktører innenfor det lokale helse- og velferdsfeltet, møtte også i starten 
litt avventende eller skeptisk respons, ifølge intervjuet med entreprenøren. Endringer i kunnskaper om - og holdninger til - selvhjelp lokalt, bedrede samarbeidsforhold, viktige allianser og konkrete resultater kom som følge av en lengre prosess og etter at det var blitt nedlagt mye arbeid. Feltteorien gjør det mulig å analysere motstand og rivalisering når det introduseres en «nykommer» i feltet. De som er der fra før, vil kunne betrakte nykommeren som en trussel (Broady, 1991), men muligheten for samarbeid og arbeidsdeling er selvsagt også til stede. Jeg vil peke på noen viktige strategiske valg:

For det første søkte ikke entreprenøren å bli anerkjent som en likeverdig konkurrent til eksisterende profesjonelle tjenester og profesjonsbaserte ideologier. Selvhjelpshuset LINK skulle ikke være et alternativ $i$ stedet for kommunens helse- og sosialtjenester. Hun søkte et samarbeid basert på komplementaritet - altså en forståelse av sitt eget virksomhetsområde som et eget felt eller subfelt ved siden av eller underordnet det eksisterende helse- og velferdsfeltet. Rådmannen definerte det på et tidlig tidspunkt som «et supplement». Det er selvsagt likevel mulig at andre aktører kan ha oppfattet dette annerledes, for eksempel at et LINK ville tråkke inn på deres faglige enemerker og være et konkurrerende alternativ. Jeg finner imidlertid ikke noe empirisk støtte for at entreprenøren har presentert seg selv og sin forståelse av selvhjelp på en slik måte.

For det andre la entreprenøren vekt på å bruke og bygge ut et personlig sosialt nettverk rundt prosjektet. Noen kjente hun fra før, men mange måtte hun ta kontakt med uten å vite hvordan de ville stille seg til prosjektet. Hun forklarte at hun som hovedregel ringte før hun sendte brev, og hun sikret seg tidlig støtte ifra innflytelsesrike nøkkelpersoner som ordfører, rådmann og lokale partiledere. Hun ble oppfattet som idealistisk og pågående, de som satt i maktposisjoner, visste etter hvert at de måtte ha saklige grunner til å avvise henne. Ifølge entreprenøren var engasjementet fra fagpersonene i kommunen varierende, men det var likevel tilstrekkelig støtte å hente.

For det tredje hadde hun en fordel av å kjenne den lokale konteksten. Hun var selv fra stedet og kjente den lokale kulturen, de ulike grupperingene og bygdene som til sammen utgjorde kommunen. Hun beskriver selv sine kommunikasjonsfremstøt som prøving og feiling og hun mener 
at det ble gjort feil. Viktigere er det likevel at hun har klart å registrere dette og justere strategien. Hun har tilpasset budskapet om et selvhjelpssenter for den lokale befolkningen og tilsynelatende lykkes med å definere dette som et eget subfelt - en egen nisje blant kommunens og foreningenes mange tilbud (Barth, 1972). Den største utfordringen her kan ha vært å presentere selvhjelpsgruppene som noe man ikke ble stigmatisert av for eksempel som noe for «alkoholikere» eller "psykiatriske pasienter», samtidig som målgruppa var folk som erkjente at de hadde et "problem» (Vang, 2010).

Dette forutsetter en vellykket avgrensning overfor andre aktører, vellykket i betydningen at de andre aksepterer avgrensningen. Selvhjelpsgruppene må da også bli vurdert og eventuelt anerkjent som «noe eget», ikke for eksempel som en amatørmessig behandlingsform eller kvasireligiøs form for sjelesorg eller en erstatning for familien. Selvhjelpsgruppeaktiviteten må verdsettes på sine egne premisser og ut fra egne kriterier - kriterier som skiller seg fra de som gjelder for de ovenfor nevnte virksomhetene. Det betyr også at selvhjelpsgrupper må bli anerkjent som dette av de andre aktørene innenfor helse- og velferdsfeltet.

Frivillige organisasjoner som selv organiserer selvhjelpsgrupper eller arbeider for pasienter eller brukeres interesser, kan også være potensielle konkurrenter til en ny selvhjelpsorganisasjon. Imidlertid har det ikke vært andre selvhjelpsorganisasjoner eller selvhjelpsgrupper lokalisert i kommunen før Selvhjelpshuset LINK. Selv om Selvhjelpshuset LINK promoterer Selvhjelp Norges modell for selvhjelpsgrupper, stilles ikke dette som noen betingelse for bruk av lokaler og fasiliteter. Andre organisasjoner kan få bruke lokalene hvis de vil opprette selvhjelpsgrupper. Entreprenøren sier at Anonyme Alkoholikere ville fătt bruke lokalene hvis de hadde villet starte en lokal gruppe. Det eneste kravet er at gruppene ikke kan være del av et offentlig behandlingstilbud. Det markeres med andre ord en grense mellom frivillighet og offentlige tjenestetilbud.

Selvhjelpsgruppene defineres også som noe annet enn frivillig drevne treffsteder eller sosiale aktivitetstilbud. Det kan diskuteres om Selvhjelpshuset LINK har aktiviteter som går inn på brukerforeningenes virksomhetsområder, når det arrangeres konferansepregete informasjonsmøter og lokale seminarer i form av såkalte «helsedugnader». Her har imidlertid 
relevante lokale brukerforeninger også deltatt som medarrangører. Forholdet mellom Selvhjelpshuset LINK og andre lokale organisasjoner/ grupperinger kan best karakteriseres som preget av arbeidsdeling og et begrenset samarbeid.

Selvhjelpshuset LINK også fått til et samarbeid med NAV-kontor, leger og offentlige psykiske helsetjenester slik at disse kan distribuere brosjyrer, gi informasjon om og i noen tilfeller anbefale selvhjelpsgrupper. Det er denne anerkjennelsen som noe faglig forsvarlig, men komplementært, fra andre viktige aktører med tilstrekkelig faglig autoritet som gir Selvhjelpshuset LINK den nødvendige symbolske kapitalen. Samtidig bekrefter dette at selvhjelpsgruppene langt på vei oppfattes som en egen nisje i det lokale helse- og velferdsfeltet - komplementært til så vel de kommunale støtte- og omsorgsordningene som til tilbudene fra sivilsamfunnets mange religiøse og humanitære foreninger og uformelle hjelpeordninger.

\section{Økonomisk kapital, eller det materielle grunnlaget for et selvhjelpssenter}

Økonomiske og materielle ressurser i form av et hensiktsmessig lokale, møbler, kontorrekvisita osv. er nødvendig for å drive informasjonsarbeid og romme selvhjelpsgruppemøter. Entreprenøren betraktet kommunen som både potensiell bidragsyter og samarbeidspart i søknader rettet mot statlige instanser. Den nye statlige tilskuddsordningen for selvhjelpsprosjekter ga en åpning. Kommunen kunne også se dette som en mulighet til å yte en egenandel for å utløse en større statlig bevilgning som ville komme innbyggerne til gode. Representanter for det lokale foreningslivet og en del viktige fagpersoner var tidlig mobilisert som støttespillere, slik at det relativt beskjedne økonomiske bidraget (under 100 ooo kr) antakelig ikke ble satt opp mot andre eksisterende tilbud.

Da stiftelsen ble opprettet og det ble vedtatt å gi Selvhjelpshuset LINK kommunale driftsmidler, hadde de første selvhjelpsgruppene kommet $\mathrm{i}$ gang. Ordføreren den gangen sa da han ble intervjuet i denne undersøkelsen, at han anså dette som godt forebyggende arbeid og at kommunen ville spare inn langt mer penger dersom bare én person gjennom selvhjelp klarte å vende tilbake til arbeidslivet. Han la til at han visste om 
minst ett konkret tilfelle der dette hadde skjedd. Slike tolkninger kan ha bidratt til at selvhjelpssenteret ikke ble oppfattet som «for dyrt» eller til fortrengsel for andre gode tiltak.

Prosjekt LINKs muligheter til å skaffe tilstrekkelig økonomisk kapital var imidlertid helt avhengig av sosial kapital i form av lokale støttespillere med riktige posisjoner. Det kan tenkes at kontaktene i Oslo også var nødvendige for å lykkes.

\section{Sosial kapital, eller det nødvendige støtteapparatet}

Nettverksarbeid og alliansebygging i de innledende fasene i prosjektet var en hovedoppgave for «ildsjelen» bak prosjekt LINK. Entreprenøren skriver i 2010 at: «Først i ettertid har jeg forstått viktigheten og nytten av denne nettverksbyggingen» (Vang, 2010, s. 21).

Entreprenøren kjente kommunen godt fordi hun var født og oppvokst der, men hun hadde bodd mye av sitt voksne og yrkesaktive liv et annet sted. Hun hadde mange kontakter inn i ulike miljøer, blant annet det læstadianske miljøet. Hun kom ikke «utenfra», men hun måtte likevel bygge opp det meste av sitt sosiale nettverk på nytt som godt voksen hjemflyttet sambygding. Hennes erfaring fra tillitsverv i brukerorganisasjonene Angstringen Nord og Mental Helse var en fordel i noen sammenhenger, men det kunne også være en ulempe i andre, for eksempel helsetjenestene. Som uføretrygdet hadde hun heller ikke en sterk sosial posisjon.

Hun forklarer i intervjuet at det «er vanskelig å bli profet i eget land» og at mange var skeptisk til henne og ideen om et selvhjelpssenter i kommunen. Hun beskriver hvor vanskelig hun syntes det var «å banke på rådmannens dør», en mann hun ikke kjente fra før, en mann med mye makt. At rådmannen ble en av hennes viktigste støttespillere, kan ha vært svært viktig for å vinne flere. Rådmannen ba etatslederne om å oppfordre sine ansatte om å gå på arbeidsseminaret - det kan ha vært avgjørende for at helse- og sosialtjenestene sluttet opp om dette.

De frivillige organisasjonene i kommunen er en annen måte å nå ut til befolkningen på. De kunne også lett oppfatte et LINK som en konkurrent 
i forhold til kommunal økonomisk støtte, og muligens også i forhold til å gi velferdstilbud til befolkningen. Entreprenøren mobiliserte mye av foreningslivet som deltakere på arbeidsseminaret og de deltok også på senere fagarrangementer i regi av selvhjelpssenteret. De inntok en samarbeidsrolle istedenfor å betrakte Selvhjelpshuset LINK som en rival - og bidro for eksempel praktisk som medarrangør til enkelte møter. Entreprenøren fikk også komme på flere av foreningenes medlemsmøter for å fortelle om selvhjelpsgrupper og om det nye senteret.

Den norske kirke i kommunen og de religiøse organisasjonene og forsamlingene har ikke hatt noen direkte samarbeidsrolle. Intervjuene tyder ikke på at de har motarbeidet selvhjelpssenteret eller entreprenøren. En informant med god kjennskap til de religiøse grupperingene i kommunen, blant annet det læstadianske miljøet, sier følgende:

Jeg har ikke klart å konkludere hva det er som har gitt Selvhjelpshuset LINK fotfeste her. Om årsaken er de eksisterende strukturene her, eller om det dekker et behov som før var udekket. Jeg tror imidlertid ikke at de har klart å bryte ned eksisterende strukturer - det er heller et supplement. (fagperson/ politiker)

Tolkningen av Selvhjelpshuset LINK som «supplement» - det samme uttrykket som rådmannen brukte overfor de kommunale tjenestene antyder at selvhjelpsgruppene ikke oppfattes som å utfordre religiøse fellesskap og praksiser med sjelesorg. På den annen side kan det virke noe påfallende at det ikke har vært mer kontakt og samarbeid med Den norske kirkes menighet som jo har diakonal virksomhet, sjelesorg og støtte til sørgende som en del av sitt oppdrag. Mange norske menigheter har for eksempel opprettet sorggrupper. Kirkens diakoniutvalg deltok på arbeidsseminaret, men ikke på senere møter. Entreprenøren uttalte i intervjuet at «det virker som kirken har monopol på sorgen».

\section{Kulturell kapital, eller kompetansen bak den nye satsningen på selvhjelp}

Selvhjelpsbevegelsen vektlegger selv erfaringskunnskapen som sin viktigste kunnskapskilde, også når den er systematisert og fortolket av de 
ansatte i Norsk selvhjelpsforum/Selvhjelp Norge og formidlet via brosjyrer, pamfletter og bøker. Entreprenørens tidligere erfaring både som gruppedeltaker og som selvhjelpsfrivillig ga henne allmenn anerkjennelse som selvhjelpsekspert. Etter hvert som Selvhjelpshuset LINK kom i drift, reiste hun mye rundt i Norge og informerte og kurset andre om selvhjelpsgrupper. Hun har også brukt sin selvhjelpskompetanse som igangsetter av selvhjelpsgrupper i kommunen og andre steder i NordNorge. Hun har dessuten lærerutdanning og benytter av og til uttrykk som viser en pedagogisk utdanning.

Entreprenøren sier selv at hun hadde sterkt behov for veiledning og støtte når det gjald å søke prosjektstøtte og utvikle og lede prosjektet. Denne kompetansen hentet hun inn ved at leder for Norsk selvhjelpsforum ble en personlig veileder. Denne lederen besøkte også kommunen flere ganger og bidro med faglige innlegg på seminarer og møter. Som nevnt deltok også en representant fra Helse- og sosialdirektoratet på minst ett av disse arrangementene. Folkehelsekoordinatoren i kommunen ble også etter hvert en medspiller som kunne levere folkehelseargumenter for dette nye tiltaket. Erfarne selvhjelpsfrivillige eller ansatte i Selvhjelp Norge prosjektet fra andre steder i Nord-Norge bidro også faglig på seminarer, kurs og informasjonsmøter sammen med entreprenøren. Samlet sett kunne Selvhjelpshuset LINK mønstre et ganske kompetent selvhjelpsfaglig korps.

En annen form for kompetanse dreier seg om kjennskap til den lokale kulturen i kommunen. Som sagt var entreprenøren selv fra bygda. Tilknytningen gjorde at hun sannsynligvis var i stand til å «lese» den lokale kulturen og tolke ulike typer respons eller mangel på respons bedre enn en som kommer utenfra. Som jeg har vært inne på, er dette viktige egenskaper hos en sosial entreprenør, samtidig som en entreprenør også må være i stand til å gå nye veier og bryte konvensjoner.

Her vil jeg trekke frem at det samtidig skjedde en sterkere vektlegging av folkehelse fra myndighetenes side. Som nevnt ble det gitt sentrale føringer om å vektlegge forebygging og samarbeide mer med frivillige for å oppnå dette. I kommunen fikk dette gjennomslag i nye helse- og rehabiliteringsplaner og opprettelsen av en egen stilling som folkehelsekoordinator. 


\section{Symbolsk kapital, eller den viktige omdømmekampen}

Symbolsk kapital er i antropologiske studier ofte forklart som ære, prestisje eller positivt omdømme. Entreprenøren var, som nevnt tidligere, frivillig i brukerorganisasjoner innen psykisk helse. Dette ga henne tyngde i form av erfaringskompetanse, men samtidig kunne det også brukes mot henne eller bidra til noens fordommer. Det var viktig for henne å formidle at selvhjelpsgrupper på Selvhjelpshuset LINK ikke var et tilbud for psykiatriske pasienter - i hvert fall ikke spesielt for dem. Dersom det ble oppfattet som stigmatiserende å delta i gruppe i regi av selvhjelpssenteret, ville mye være tapt for selvhjelpssaken, slik entreprenøren så det. Det ville gi senteret lav symbolsk kapital i kommunens sivilsamfunn. Den andre fallgruven entreprenøren var opptatt av, var å ikke komme i diskreditt hos de profesjonelle tjenestene i kommunen. Selvhjelp måtte ikke pretendere å være likestilt med behandling. Som en av de intervjuede fagpersonene sa: «... det er litt farlig å si at selvhjelp er terapi! For da er du jo liksom i sånn ... da kommer du kanskje litt sånn i konflikt med ... medisin, altså ordinær medisin».

I tillegg til at de profesjonelle ikke måtte tolke selvhjelpsgrupper som en form for «alternativ behandling» - i intervjuet brukte en av informantene selv uttrykket «kvakksalveri» - er det svært viktig å bli oppfattet som forsvarlig og ansvarlig. Det vil ofte dreie seg om to ting: Det ene er at selvhjelpsgruppene ivaretar en form for taushetsplikt, det andre er at de ikke fungerer slik at deltakere med psykiske lidelser blir dårligere av det. Intervjuene avspeiler at dette har vært temaer som har blitt diskutert i møter mellom de selvhjelpsfrivillige og fagpersoner i kommunen.

En annen fagperson sa i intervju at skepsisen mot selvhjelpssenteret var sterkest i begynnelsen, at det var litt uklart om det skulle oppfattes som en form for behandling:

Intervjuer: Du sa det har blitt oppfattet som å være litt i konkurranse til de profesjonelle? Var det i en tidlig fase?

Fagperson: Ja. Nevnte da at hvis det var en med alkoholproblemer, for eksempel ... tror de gikk ut med det. Det var skepsis på fagsiden. «De skal jo ikke drive med terapi!» Utenom det har det ikke kommet opp som tema. Den gangen 
konkurrerte de med fagsynet. Men jeg tror de har funnet sin nisje. Lekmannsprinsippet har fått feste.

Det har nok vært en viss skepsis hele tiden blant fagpersoner, men støtten fra rådmannen, Helse- og sosialdirektoratet, etatsledere og folkehelsekoordinator har bidratt til å gi selvhjelpssenteret tilstrekkelig symbolsk kapital. Samtidig kan det selv for positivt innstilte ansatte innenfor tjenesteapparatet ha virket uklart hva et "LINK» er for noe, siden selvhjelpsgrupper fra før er mest kjent som AA-grupper eller støttegrupper tilknyttet sykehus eller en pasientorganisasjon.

Informasjonsarbeidet er også et symbolsk arbeid i forhold til å skape et rom i folks bevissthet for begrepene «selvhjelp» og «selvhjelpsgruppe». I befolkningen har kanskje ordførernes støtte over tid, og med ulike partibakgrunner, og mye positiv medieomtale som blant annet har fremhevet kommunen som "pioner-kommune» og lignende, hatt størst betydning. Entreprenøren har gjort seg en del refleksjoner rundt spørsmål som: Hvordan formidle noe som lokalsamfunnet ikke har kjennskap til fra før, noe som mange ikke engang har et begrep om?

Vi ser også at avisoppslag har vært nødvendig folkeopplysningsarbeid. Det er ikke vi selv som har skrevet dette, andre har vurdert arbeidet og formidlet det med sine egne ord. Kanskje journalistenes språk gjorde selvhjelp som fenomen mer tilgjengelig for menneskene rundt oss? (Vang, 2010, s. 30)

Selvhjelpshuset LINK trengte hjelp til å markedsføre seg selv. Under åpningen fikk det nye senteret to bilder i gave fra kommunen. Folkehelsekoordinatoren overrakte bildene som hadde abstrakte motiver og sa at de symboliserte «det litt diffuse som senteret enda opplevdes som for oss her i kommunen» (Vang, 2010, s. 31).

\section{Konklusjon - sosialt entreprenørskap og samhandling med offentlige aktører}

Distriktskommunen som studeres her, hadde svært liten tradisjon for selvhjelpsgrupper fra før. Likevel søkte de, i samarbeid med organisasjonen Norsk selvhjelpsforum, om prosjektmidler fra Helse- og sosialdirektoratet for å etablere et LINK, et «treffsted for mennesker som arbeider 
med selvhjelp helt uavhengig av hvilken diagnose eller livsproblem vedkommende har» (Vang, 2010, s. 15). Slike selvhjelpsgrupper som verken var AA eller basert på en diagnose, virket ukjent, ikke bare for lokalbefolkningen, men også fagpersoner i kommunen.

Med statlige midler i ryggen, og støtte fra den sentrale kommuneledelsen, ble det utviklet en livskraftig organisasjon i løpet av prosjektperioden. Det ble avholdt konferanser, folkemøter og en rekke informasjonsmøter. Det ble også startet opp to selvhjelpsgrupper allerede før Selvhjelpshuset LINK ble formelt opprettet som en egen stiftelse med kommunale driftsmidler i 2008.

Hva var det med den lille distriktskommunen som gjorde at dette lyktes? Ifølge den lokale entreprenøren, av sambygdinger betegnet som en «ildsjel», så ble selvhjelpssenteret mulig «til tross for», ikke "på grunn av», egenskaper ved denne kommunen. De andre intervjuene gir heller ingen holdepunkter for at den lokale kulturen var mer mottakelig enn i andre lokalsamfunn, eller at den spesielt favoriserte en selvhjelpsorganisasjon. Den viktigste faktoren kan ha vært en lokal sosial entreprenør, som ikke bare var dedikert til å formidle den nye selvhjelpsbevegelsens selvhjelpsforståelse og realisere et selvhjelpssenter, men også hadde forutsetninger for å «lese» den kulturelle konteksten. Eksempelet Selvhjelpshuset LINK illustrerer også betydningen av å finne alliansepartnere og strategisk posisjonerte pådrivere, en effektiv kommunikasjonsstrategi og vilje til å justere kursen underveis.

Entreprenøren sier selv at «ingen blir profet i eget land», og det ligger nok mye egen erfaring bak dette utsagnet. Mistro kan ha vært begrunnet $i$ at skeptikerne nettopp mente at de kjente henne. Entreprenøren overrasket mange i lokalsamfunnet med hva hun fikk til og anerkjennelsen hun fikk utenfra. Samtidig kan evnen til å «lese» den lokale kulturen ha vært avgjørende for å manøvrere seg gjennom denne prosessen.

Den formen for sosialt entreprenørskap som jeg har beskrevet i denne studien, er analysert som en kamp for å posisjonere seg gjennom mobilisering av ulike typer ressurser. Å skape et rom for selvhjelpsarbeid i distriktskommunen har dreid seg om å realisere tilstrekkelig økonomisk, sosial, kulturell og symbolsk kapital - til å etablere en ny nisje innenfor et lokalt helse- og velferdsfelt.

Eksempelet viser også hvor viktige alle de nevnte kapitalformene er for at et prosjekt skal lykkes. Man kan forestille seg at lokale ildsjeler engasjerer 
seg for å etablere selvhjelpsgrupper, men at det stopper opp fordi de fysiske lokalitetene er uegnede, eller fordi økonomien til å drive informasjonsarbeid mangler. Man kan også se for seg et kommunalt finansiert selvhjelpsmøtelokale som står tomt, fordi ingen frivillige vil drive det eller ingen motiverer potensielle deltakere til å benytte det. Riktig kompetanse hos dem som skal drive et slikt senter, er også vesentlig, både for informasjonsarbeidet og for å bli tatt alvorlig av myndigheter. Å få anerkjent sin kompetanse er viktig for senterets totale omdømme, men det er heller ikke tilstrekkelig. Selv når de materielle betingelsene er på plass, det har et nettverk av støttespillere og det er dyktige folk til å drive senteret, kan prosjektet møte veggen. Dersom befolkningen oppfatter selvhjelpsgrupper som stigmatiserende, eller noe som ikke angår dem, vil det bli irrelevant. Dersom ansatte i den lokale helse- og sosialtjenesten mistror senteret og motarbeider det, vil det undergrave den legitimiteten som det er avhengig av.

Etableringen av Selvhjelpshuset LINK er et interessant eksempel på sosialt entreprenørskap i praksis. Erfaringen fra denne kommunen viser også et eksempel på en form for offentlig-frivillig samarbeid som er karakteristisk for de nordiske velferdssamfunnene: Den sosiale entreprenørens lokale troverdighet og handlingsevne ble støttet opp av de offentlige myndighetenes legitimeringsmakt og økonomiske incitament gjennom egne tilskuddsordninger.

Den symbolske kampen dreier seg ikke bare om å heve selvhjelpsgruppenes omdømme innenfor helse- og velferdsfeltet på de eksisterende premissene, men også om å endre definisjonen av hele feltet slik at selvhjelpens særpreg kommer bedre til sin rett. De statlige policy-dokumentene som peker ut folkehelsesatsing, en samarbeidsrolle for frivilligheten og sterkere vekt på allmenn forebygging, ga drahjelp til selvhjelpsprosjektet i dette lokalsamfunnet. Samtidig passet det lokale prosjektet som hånd i hanske for myndighetenes helsepolitiske målsettinger. Midt i mellom det lokale og sentrale, myndigheter og frivillige, har Norsk selvhjelpsforum spilt en nøkkelrolle.

\section{Referanser}

Barth, F. (1967). Economic spheres in Darfur. I R. Firth (Red.), Themes in economic anthropology (s. 149-174). London: Tavistock. 
Barth, F. (1972). The Role of the entrepreneur in social change in Northern Norway. Bergen: Universitetsforlaget.

Borch, O. J. \& Førde, A. (2010). Innovative bygder - en introduksjon. I O. J. Borch \& A. Førde (Red.), Innovative bygdemiljø (s. 13-26). Bergen: Fagbokforlaget.

Borch, O. J. \& Vestrum, I. (2010). Samfunnsentreprenøren og «de gode hjelperne». I O. J. Borch \& A. Førde (Red.), Innovative bygdemiliø (s. 83-94). Bergen: Fagbokforlaget.

Bourdieu, P. \& Wacquant, L. J. D. (1992). An invitation to reflexive sociology. Cambridge: University of Chicago Press.

Broady, D. (1991). Sociologi och epistemologi: Om Pierre Bourdieus författarskap och den historiska epistemologin (2. korr. uppl. utg.). Stockholm: HLS förlag.

Dean, M. (2006). Governmentality. Magt \& styring $i$ det moderne samfund. Frederiksberg C: Forlaget Sociologi.

Fligstein, N. \& McAdam, D. (2010). Toward a general theory of strategic action fields (Working Paper Series). Berkeley: Institute for Research on Labor and Employment, UC Berkeley.

Førde, A. \& Borch, O. J. (2010). Innovative bygdemiljø: Ildsjeler og nyskapingsarbeid. Bergen: Fagbokforlaget.

Førde, A., Kramvig, B., Gunnerud, N. \& Dale, B. (2013). Å finne sted: Metodologiske perspektiver $i$ stedsanalyser. Trondheim: Akademika forlag.

Helse- og omsorgsdepartementet. (2011). Innovasjon i omsorg. Oslo: Helse- og omsorgsdepartementet.

Helse- og omsorgsdepartementet. (2013). Folkehelsemeldingen: God helse - felles ansvar. [Oslo]: Departementenes servicesenter.

Helsedepartementet. (2003). Resept for et sunnere Norge / folkehelsepolitikken. Oslo: Departementet.

Ingstad, E. S. L. (2009). Sosialt entreprenørskap - en klargjøring av begrepet. I B. Schei \& E. Rønnevig (Red.), Vilje til endring. Sosialt entreprenørskap på norsk. Notodden: Mother Courage.

Nilsen, T. (2006, 9. november). Du må ha et problem. Framtid $i$ Nord.

Nyseth, T. \& Aarsæther, N. (2013). Fra implisitt til eksplisitt komparasjon: komparativ metode i stedsforskning. I A. Førde, B. Kramvig, N. Gunnerud \& B. Dale (Red.), A finne sted: Metodologiske perspektiver i stedsanalyser (s. 221-236). Trondheim: Akademika forlag.

Rose, N. (2006). Governing 'advanced' liberal democracies. I A. Sharma \& A. Gupta (Red.), The anthropology of the state (s. 144-162). Malden: Blackwell Publishing. Røiseland, A. (1999). Lokalsamfunn og helse. Forebyggende arbeid i en brytningstid. Bergen: Fagbokforlaget. 
Sosial- og helsedirektoratet. (2004). Nasjonal plan for selvhjelp. Oslo: Helsedirektoratet.

Vabo, S. I. \& Røiseland, A. (2008). Governance på norsk. Samstyring som empirisk og analytisk fenomen. Norsk statsvitenskapelig tidsskrift, (1-2).

Vang, G. A. (2010). En virkelighetsbeskrivelse av arbeidet med etablering og forankring av Senter for selvhjelp og mestring Lyngen: LINK Lyngen/Lyngen kommune. 



\title{
KAPITTEL 7
}

\section{Fra felt til verktøy: Om Selvhjelp Norge som koordinerende enhet}

\author{
Hilde Hatleskog Zeiner
}

By- og regionforskningsinstituttet NIBR, OsloMet -Storbyuniversitetet

\begin{abstract}
Since 2004, Norway has a National plan for self-help. The plan results from the collaboration of the Directorate for Health and the Norwegian Self-Help Forum, a civil society organization. The chapter asks whether and how the plan coordinates the efforts and activities of self-help organizations and other civil society actors. It compares two cooperative efforts between civil society actors in the self-help field: the self-help seminars of the 1990s and the establishment of LINK Trondheim in 2014. The analysis shows that the national plan for self-help has transformed the field, but not as envisaged in the 2004 plan. The chapter suggests that the diagnosis informing the plan was flawed. That rather than being a sign of fragmentation, diversity is an indication of a well-functioning self-help field. It argues, therefore, that it is problematic that the plan, rather than representing diversity, promotes a particular understanding and approach to self-help. Whereas a central idea in the 2004 plan was to build stronger ties and networks between civil society actors, interviews with actors involved in the establishment of LINK Trondheim, as well as other civil society organizations, indicate that there is less interaction between the organizations today than 20 years ago. Instead, Self-Help Norway seems to have turned to other actors, such as welfare producers, welfare professionals, and public authorities. The question, then, is whether we are witnessing the contours of a new self-help field, organized around other actors, interests and resources.
\end{abstract}

Keywords: self-help/mutual aid, strategic action fields, civil society organizations, coordination, governance unit

\section{Innledning}

Siden 2004 har Norge hatt en nasjonal plan for selvhjelp (Helsedirektoratet, 2014b; Sosial- og helsedirektoratet, 2004). ${ }^{1}$ Planen er et resultat av et mange-

$1 \quad$ Nasjonal plan for selvhjelp ble revidert i 2014, og løper ut 2018.

Sitering av dette kapittelet: Zeiner, H. H. (2019). Fra felt til verktøy: Om Selvhjelp Norge som koordinerende enhet. I Å. Brottveit \& M. Feiring (Red.), Samarbeid om selvhjelp. En antologi om den nye selvhjelpsbevegelsen $i$ Norge (s. 167-189). Oslo: Cappelen Damm Akademisk. https://doi.org/10.23865/noasp.68.ch7 Lisens: CC BY 4.0 
årig samarbeid mellom offentlige myndigheter, representert ved Helsedirektoratet, og sivilsamfunnet, representert ved Norsk selvhjelpsforum (Zeiner, 2014). Planens utgangspunkt er at selvhjelpsfeltet er «uensartet, fragmentert og preget av svakt utviklet samhandling», og at det er behov for en sterkere koordinering (Sosial- og helsedirektoratet, 2004, s. 12). Koordineringen skal blant annet skje gjennom begrepsavklaring og metodeutvikling (Sosialog helsedirektoratet, 2004, s. 9). Et av virkemidlene er derfor etablering av en koordinerende enhet som skal drive «informasjons- og formidlingsarbeid, kunnskapsutvikling og være koordinator i et nettverk for selvhjelp» (Helsedepartementet, 2003; Sosial- og helsedirektoratet, 2004, s. 14). Etter utlysning ble Norsk selvhjelpsforum tildelt oppdraget, og det nasjonale knutepunktet for selvhjelp - Selvhjelp Norge - ble opprettet i 2006.

Nasjonal plan beskriver knutepunktfunksjonen som en «koordinator og møteplass for nettverksarbeid» (Sosial- og helsedirektoratet, 2004, s. 10). Over tid har knutepunktfunksjonen blitt nedtonet, samtidig som Selvhjelp Norge i økende grad har orientert seg mot offentlige myndigheter (Zeiner, 2014). I dette kapittelet diskuterer jeg hvordan denne utvikling kan forstås. Har nasjonal plan for selvhjelp bidratt til å koordinere innsatsen til frivillige organisasjoner som driver selvhjelpsrelatert arbeid? Spørsmålet er todelt: For det første handler det om hvorvidt nasjonal plan har medført endringer både i aktørenes atferd og i relasjonene mellom dem. For det andre handler det om hva som forklarer slike eventuelle endringer. Jeg nærmer meg spørsmålet gjennom en sammenligning av to samarbeidsprosjekt, et før og et etter nasjonal plan for selvhjelp. På midten av 1990-tallet samlet seminarrekken Selvhjelp på norsk en rekke aktører for å diskutere forutsetninger og betydninger av selvhjelp, samt etableringen av strukturer for informasjons- og erfaringsutveksling. I perioden 2012 til 2014 møttes en rekke lokale aktører for å diskutere behov for, og innretning av, en lokal møteplass for selvhjelp i Trondheim.

Gjennomgangen er strukturert som følger: Først presenterer jeg de to casene, og ser på hvorvidt og på hvilke måter diskusjonene og forståelsen av selvhjelp har endret seg fra midten av 1990-tallet og frem til i dag. Dernest diskuterer jeg hva som kan forklare eventuelle endringer. Jeg ser på hvem som ønsket/ønsker koordinering, hva slags koordinering som etterspørres, og hvilke ressurser som er viktige for de ulike aktørene. 
Jeg starter imidlertid med en gjennomgang av forskningsdesign: teori, metode og datamateriale.

\section{Forskningsdesign}

Kapittelet anvender Fligstein og McAdam (2012) sin teori om strategiske felt for å forstå hvilken betydning nasjonal plan for selvhjelp har for selvhjelpsfeltet. Teorien kombinerer ulike aspekter fra teorier om sosiale bevegelse, institusjonell teori (blant annet DiMaggio \& Powell, 1983) og feltteori (Bourdieu, 1993) for å beskrive hvordan sosiale bevegelser og institusjoner vokser frem, endres, befester sin situasjon eller forvitrer. Teorien om strategiske felt har som utgangspunkt at posisjoner og relasjoner ikke er gitt, men skapes gjennom interaksjoner mellom feltets aktører og gjennom samhandling med aktører på andre, tilgrensende felt (Fligstein \& McAdam, 2012).

Nasjonal plan for selvhjelp kan forstås som et forsøk på å nedfelle selvhjelpfeltets formål, relasjoner og handlingsrom, og at Selvhjelp Norge er gitt rollen som feltets koordinerende enhet. En koordinerende enhet har tre sentrale funksjoner (Fligstein \& McAdam, 2012, s. 13-14): Den sikrer at feltets spilleregler overholdes; at aktørenes interaksjoner er i samsvar med etablerte forståelser av feltets formål, relasjoner og handlingsrom. Gjennom sin eksistens legitimerer den videre feltets logikk og spilleregler, blant annet gjennom informasjonsinnhenting og kunnskapsformidling. Til sist fungerer den som et bindeledd mellom det strategiske feltet og tilgrensende felt. En koordinerende enhet vil som regel ikke være nøytral. Den skal ikke være en uhildet konfliktløsningsmekanisme, men skal opprettholde status quo, og dermed også interessene til feltets dominerende aktører (Fligstein \& McAdam, 2012).

Hva ligger i planens koordineringsfunksjon? Planen fra 2004 vektlegger nettverksfunksjonen (Sosial- og helsedirektoratet, 2004). Den reviderte planen vektlegger forvaltning og formidling av verktøyet selvorganisert selvhjelp (Helsedirektoratet, 2014b). I 2004 er det et mål «å bidra til at ulike aktører blir aktive deltakere i utvikling av selvhjelpsarbeidet» (Sosial- og helsedirektoratet, 2004, s. 12), og derigjennom bidra til utviklingen av kontekstualisert kunnskap (Munn-Giddings \& Borkman, 
2005). I 2014 er det en abstrahert og dekontekstualisert modell for selvhjelp som presenteres; den skal være gyldig uavhengig av hvem du er eller hvilket problem du har. Målet er ikke å bidra til begrepsutvikling, men å sikre at denne bestemte tilnærmingen til selvhjelp gjøres kjent for befolkningen (Helsedirektoratet, 2014b).

De første årene etter opprettelsen i 2006 bar Selvhjelp Norge preg av å være en organisasjon på leting etter sin form (Rambøll Management, 2014). Etter få års drift forlot organisasjonen nettverksmodellen og bygget opp en mer hierarkisk struktur bestående av et hovedkontor, distriktskontor og flere lokale kontaktpunkt (Zeiner, 2014). Flere av virkemidlene i planen ble avviklet eller nedtonet, ${ }^{2}$ og Selvhjelp Norge begynte å omtale seg som et kompetansesenter for selvorganisert selvhjelp (Selvhjelp Norge, 2011). Da Selvhjelp Norges distriktskontor for Møre og Romsdal og Nord- og Sør-Trøndelag i 2012 inviterte til «åpent møte om selvorganisert selvhjelp sammen med lokale krefter» (Selvhjelp Norge, udatert-a) var det således kompetansesenteret, og ikke knutepunktet, som stod bak.

Jeg har undersøkt hvilken betydning Selvhjelp Norge har for andre aktører. Nærmere bestemt spør jeg hvilken betydning Selvhjelp Norges begrepsavklaringsarbeid har hatt for relasjoner og interaksjoner på selvhjelpsfeltet. Begrepsavklaringer har betydning for endring eller opprettholdelse av samfunnsstrukturer (Kurunmäki, 2012), også maktstruktur innenfor et felt. Det vil i vårt tilfelle innebære forståelser av selvhjelpsfeltets formål og spilleregler, og dermed aktørenes handlingsrom, posisjoner og relasjoner. Jeg sammenligner to samarbeidsprosesser på selvhjelpsfeltet. Selvhjelp på norsk-seminarene fant sted før, mens etableringen av LINK Trondheim skjedde etter at nasjonal plan for selvhjelp ble laget. Felles for disse samarbeidsprosessene er at de ikke handlet om arbeidet $\mathrm{i}$ gruppene, men om å etablere strukturer rundt gruppenes og selvhjelpsorganisasjonenes arbeid.

Datamaterialet fra de to samarbeidscasene er ulikt. Innleggene fra selvhjelpsseminarene på 1990-tallet er publisert i rapportene Selvhjelp på

2 Et av tiltakene i nasjonal plan var en tilskuddsordning for prosjektstøtte som skulle bidra til å stimulere selvhjelpsarbeid innen psykisk helse. Ordningen ble opprettet i 2005 (Helse- og omsorgsdepartementet, 2005), og avviklet i 2009 til fordel for oppbygging av Selvhjelp Norges distriktskontor (Selvhjelp Norge, 2010). Videre ble en referansegruppe for Selvhjelp Norge, bestående av flere sentrale sivilsamfunnsaktører, faset ut etter utløpet av perioden 2006-2008. 
norsk (Nilsen \& Talseth, 1995) og Selvhjelp på norsk 2 (Sandvik, 1996b). Rapportene gir innblikk i sentrale aktørers vurdering av de tema som var på dagsorden, men ikke diskusjonene mellom dem eller deres vurdering av andre innlegg. Jeg har ikke tilsvarende skriftlige kilder fra opprettelsen av LINK Trondheim. Her har jeg i første rekke basert analysen på intervjuer med utvalgte deltakere i prosessen: daværende leder for distriktskontoret, distriktskontorets kontaktperson i Trondheim kommune, Velferdsalliansen, Vårres regionalt brukerstyrt senter Midt Norge (Vårres), SiT Råd og Batteriet/ Kirkens bymisjon. Leder for distriktskontoret var behjelpelig med å identifisere aktuelle informanter. Intervjuene ble gjennomført høsten 2014. Med unntak av leder for distriktskontoret ble samtlige intervjuer gjennomført på telefon. Som supplement til intervjuene med de lokale aktørene har jeg også inkludert intervjuer med noen utvalgte nasjonale selvhjelpsaktører: Støttesenter mot incest, Retretten, Landsforeningen uventet barnedød, Landsforbundet mot stoffmisbruk, Personskadeforbundet/LTN og Angstringen. Intervjuene ble gjennomført på telefon i første halvdel av 2013, og inkluderte spørsmål knyttet til organisasjonenes virksomhet, selvhjelpsforståelse, gruppeaktiviteter og kjennskap til / samarbeid med Selvhjelp Norge.

Med utgangspunkt i teorien om strategiske felt har jeg formulert et sett med spørsmål for å kategorisere og analysere aktørenes forståelse av begrepet selvhjelp og selvhjelpsfeltets formål, posisjoner og relasjoner. Hvordan forstår aktørene «selvhjelp»? Hvordan definerer de sine interesser og målsettinger, og feltets interesser og målsettinger? Hvordan forstår aktørene seg selv og sin rolle? Hvordan forstår og beskriver de feltets øvrige aktører? Hvordan forstår aktørene feltets spilleregler? Hva mener aktørene om koordinering av feltet, og behov for og innretning av en koordinerende enhet? Formålet er å avklare om relasjonene mellom selvhjelpsaktørene har endret seg før og etter nasjonal plan for selvhjelp, og på hvilken måte politiske føringer påvirker relasjonene.

\section{Fra Selvhjelp på norsk til Selvhjelp Norge}

I 1995 og 1996 samlet seminarrekken Selvhjelp på norsk selvhjelpsorganisasjoner, deltakere, frivillige og profesjonelle støttespillere for å diskutere 
hva selvhjelp er og kan være, og hvordan selvhjelpsgrupper og selvhjelpsorganisasjoner kan og bør samarbeide med hverandre, med offentlige myndigheter og med hjelpeapparatet. Initiativtaker var Studiesenteret for selvhjelp, som beskrev selvhjelpsfeltet som fragmentert og «identitetsmessig presset» (Hjemdal, 1996, s. 14), og som så behov for at aktørene utvikler en «bevissthet om seg selv som samlet felt» (Hjemdal, Nilsen \& Seim, 1998, s. 236). ${ }^{3}$ Representanter for Anonyme Alkoholikere (AA), Angstringen, Interessegruppa for kvinner med spiseforstyrrelser (IKS), prosjektet «Sorg og omsorg», Frivillighetssentralen i Sarpsborg og Studiesenteret stod for planlegging og organisering av seminarene, og var også sentrale bidragsytere. (For en fullstendig liste over innlegg og deltakere, se Nilsen \& Talseth, 1995; Sandvik, 1996b.) Seminarene kan forstås som et første, vidtrekkende forsøk på nettverks- og relasjonsbygging mellom aktørene på selvhjelpsfeltet (Zeiner, 2014).

Et gjennomgangstema i innleggene er hvordan selvhjelp kan defineres og avgrenses. Særlig er selvhjelpsorganisasjonene opptatt av dette. Fire trekk ved selvhjelp fremheves: felles problem/behov, gjensidighet, autonomi og erfaringsbasert kunnskap (Zeiner, 2014). Utgangspunktet «er at en kommer sammen med en gruppe personer som er i lignende situasjon/ har et felles problem» (Goksøyr, 1995, s. 38), og «arbeider med denne situasjonen eller problemet sammen» (Sandvik, 1995, s. 67). Videre er relasjonene mellom deltakerne preget av gjensidighet og likeverd. Det ikke hjelpere og mottakere i en selvhjelpsgruppe, snarere er «gjensidig utbytte (...) den bærende kraft» (Talseth, 1995, s. 33). Slik gjensidighet forutsetter at selvhjelpsgruppene er autonome; at de selv legger føringer for sin egen virksomhet (se blant annet Hjemdal et al., 1998). I dette ligger det også en forventning om at gruppene utvikler kollektiv kunnskap basert på deltakernes egne erfaringer og opplevelser.

Det er imidlertid også viktige forskjeller i måten deltakerne definerer selvhjelp på; forskjeller som særlig handler om selvhjelpens avgrensning mot interessepolitikk. Blant deltakerne finner vi både aktører med et uttalt sosialpolitisk formål og aktører med en mer terapeutisk tilnærming

3 Studiesenteret var et tidsavgrenset prosjekt knyttet til Høgskolen i Oslo (for mer informasjon om prosjektet, se Hjemdal et al., 1998). 
til selvhjelp. På den ene siden finner vi AA, som av prinsipp aldri uttaler seg politisk, og Angstringen, som rendyrker den terapeutiske tilnærmingen. De beskriver selvhjelp som et verktøy for individuelle endringsprosesser, og selvhjelpsgruppen som et forum hvor mennesker regelmessig samles for å snakke fokusert om sine livsproblem (jf. Gotaas, 2012). På den andre siden finner vi Klientaksjonen i Fredrikstad og Studiesenteret, som mener at selvhjelp både handler om individets bevisstgjøring og om en kollektiv motmakts- eller frigjøringsprosess (Hjemdal et al., 1998; Johannessen, 1995).

Samlet sett tegner innleggene et bilde av et mangfoldig felt: mange tema, mange aktører og mange ideer om nettverksbygging (Zeiner, 2014). De ulike definisjonene har noen likhetstrekk som gjør det mulig for deltakerne å gjenkjenne selvhjelp som aktivitet. Samtidig er det tydelig at definisjonene også er tilpasset den enkelte organisasjons virksomhet. De er lokale, kontekstuelle og spesifikke (jf. Scott, 1998), formet av den sosialpolitiske sammenheng de er oppstått i (Seebohm, Munn-Giddings \& Brewer, 2010). Den enkelte selvhjelpsorganisasjon opererer altså med relativt veldefinerte prinsipper for sin virksomhet, mens feltet som helhet er preget av et mangfold av tilnærminger. Enkelte av seminardeltakerne tar til orde for sterkere koordinering av selvhjelpsfeltet. Selv om ingen av dem er i posisjon til å få gjennomslag for sin foretrukne samarbeidsmodell (Zeiner, 2014), viser nasjonal plan til arbeidet som «startet i frivillig sektor på 1990-tallet» for å begrunnet behovet for en koordinerende enhet (Helsedirektoratet, 2014b, s. 9).

Nesten to tiår senere, når representanter for ulike lokale sivilsamfunnsaktører møtes til dialogmøte i Trondheim, er en slik koordinerende enhet etablert. Selvhjelp Norge kaller seg nå et nasjonalt kompetansesenter for selvorganisert selvhjelp (Selvhjelp Norge, 2013), og formidler en forståelse av selvhjelp som et verktøy basert på prinsipper definert av Angstringen på 1990-tallet (Selvhjelp Norge, 2009; jf. Sosial- og helsedepartementet, 1993, s. 25). Selvhjelp Norges distriktskontor inviterer lokale aktører til et møte «for å finne ut hvilken nytte de kan ha av selvhjelp, og hvordan vi sammen kan legge grunnlaget for et kontaktpunkt i Trondheim» (Selvhjelp Norge, udatert-a). I invitasjonen, som ble lagt ut på Selvhjelp Norges hjemmesider (Selvhjelp Norge, udatert-a), presiseres det at det er en 
bestemt form for møteplass som skal etableres, nemlig et LINK. ${ }^{4}$ Samtidig er det en uttalt målsetting at møteplassen skal være «lokalt forankret» (Intervju med leder for distriktskontoret 29.09.14), noe som skal skje gjennom «en dialog med organisasjonene» (Selvhjelp Norge, udatert-a).

Intervjuene med deltakerne gir et uklart bilde av prosessen. Informantene gir ulike svar på hvordan arbeidet var organisert, hvem som deltok, og hvilke aktører som var sentrale. I fravær av skriftlige kilder er det derfor kun mulig å presentere et omriss av prosessen, som er som følger: Selvhjelp Norge arrangerte i oktober 2012 et dialogmøte med representanter fra blant annet Angstringen, AA, FFO i Sør-Trøndelag, Kreftforeningen, Batteriet/Kirkens bymisjon, Velferdsalliansen, Vårres og Personskadeforbundet/LTN (Selvhjelp Norge, udatert-b). På dette møtet ble det nedsatt en ressursgruppe. Gruppen utarbeidet en søknad til Trondheim kommune, som så utlyste oppdraget om å drifte LINK Trondheim med finansiering fra kommunen. I konkurranse med to andre søkere, hvorav Vårres var én, fikk Trondheim Røde Kors oppdraget. I mai 2014 åpnet LINK Trondheim dørene.

Her er jeg imidlertid mindre interessert i selve prosessen, og mer interessert i deltakernes forståelse av selvhjelp og Selvhjelp Norges rolle som koordinerende enhet. Ser vi på Selvhjelp Norges rolle, fremkommer det at det er distriktskontoret som definerer rammene for prosessen. Tydeligst kommer dette frem ved at den kommende møteplassen beskrives som «nøytral» (Selvhjelp Norge, udatert-a). Begrepet «nøytral» signaliserer ikke at ulike tilnærminger til selvhjelp skal sidestilles, men snarere at LINK Trondheim skal drives i samsvar med Selvhjelp Norges modell for selvorganisert selvhjelp hvor selvhjelpsgrupper ikke organiseres rundt særskilte problem eller diagnoser, men settes sammen på tvers av problematikk (Intervju distriktskontoret 29.09.2014). Vårres utfordrer denne modellen: gjennom å insistere på en forståelse av selvhjelp som verken krever at møteplassen eller gruppene er «nøytrale», og gjennom ambisjonen om å drifte LINK Trondheim (Intervju distriktskontoret 29.09.2014;

$4 \quad$ Et LINK skal være «en dedikert møteplass for selvorganisert selvhjelp og en nøytral arena for selvorganiserte selvhjelpsgrupper» (Selvhjelp Norge, 2016:6). LINK-modellen ble utviklet av Norsk selvhjelpsforum som etablerte LINK Oslo i 2004 med støtte fra Oslo kommune. På det meste var det fire LINK i Norge. I dag er det to: LINK Oslo og LINK Trondheim. 
Intervju Vårres 27.10.2014). Før det første dialogmøtet var det imidlertid etablert kontakt mellom Selvhjelp Norge og Trondheim kommune, som blant annet innebar en intensjon om kommunal finansiering av møteplassen (Intervju distriktskontoret 20.09.2014). Vårres har ikke nødvendige ressurser for å utfordre dette samarbeidet. Senteret lykkes ikke i å endre arbeidsgruppens forståelse av hvordan møteplassen bør utformes, og når heller ikke frem med sin søknad om å drive LINK Trondheim.

Ser vi på informantenes forståelser av selvhjelpsbegrepet, finner vi at informantene i varierende grad deler Selvhjelp Norges forståelse. Vi gjenfinner mange av argumentene og posisjonene fra 1990-tallets selvhjelpsseminarer. Dette gjelder særlig spørsmålet om selvhjelp som terapi versus selvhjelp som sosial mobilisering. SiT Råd ${ }^{5}$ er den som tydeligst vektlegger det terapeutiske aspektet. Selvhjelp beskrives som «en effektiv og god måte» for å «håndtere og jobbe med sine utfordringer. (...) Det handler om å ta ansvar for (...) eget liv og egne utfordringer» (Intervju SiT Råd 30.10.2018). De øvrige organisasjonene vektlegger i ulik grad sosial mobilisering. Tydeligst kommer dette frem hos Velferdsalliansen ${ }^{6}$ og Batteriet, som begge har uttalte sosialpolitiske formål, og som definerer sin virksomhet som en form for selvhjelp. Velferdsalliansens ambisjon var å representere de «ekskluderte marginaliserte» (Intervju Velferdsalliansen 27.10.2014), og å sørge for at ikke bare helseproblem, men også sosiale, økonomiske og rettslige aspekter ble en del av diskusjonene. Batteriet ${ }^{7}$ aksepterer at det er den terapeutiske tilnærmingen som er rammen for LINK Trondheim, og ser verdien av at sosial mobilisering suppleres med en form for selvhjelp hvor deltakerne «myndiggjør hverandre, og er med på å styrke hverandre og få nye roller» (Intervju Batteriet 29.10.2014). Våres inntar en posisjon som minner om den IKS hadde på 1990-tallet (jf. Zeiner, 2014), ved at senterets virksomhet både er innoverrettet, mot brukerne og deres pårørende, og utoverrettet, mot fagmiljøer og

5 SiT Råd er en del av Studentsamskipnaden i Trondheim (SiT) og tilbyr kurs som skal hjelpe studenter til å «takle alt fra tidsplanlegging til depresjoner» (SiT, udatert).

6 Velferdsalliansen er et samarbeidsnettverk av organisasjoner, foreninger og aksjonsgrupper for $ø$ konomisk-, sosialt-, og rettslig vanskeligstilte grupper i Norge (Velferdsalliansen, udatert).

7 Batteriet tilbyr støtte til organisasjoner og grupper som jobber mot fattigdom og sosial ekskludering, og beskriver seg som et «ressurssenter for egenorganisering, selvhjelp og påvirkningsarbeid» (Batteriet, udatert). Batteriet er en del av Kirkens Bymisjon. 
det offentlige hjelpeapparatet (Vårres, 2017). I likhet med selvhjelpsorganisasjonene på 1990-tallet vektlegger også Vårres at selvhjelpsgrupper organiseres rundt et felles problem (Intervju Vårres 27.10.2014). En klar forskjell fra 1990-tallet er at aktørene i Trondheim skal forme en konkret møteplass. I dette arbeidet kontrollerer Selvhjelp Norge viktige ressurser, gjennom sin rolle som kompetansesenter og sin relasjon til offentlig myndigheter. På selvhjelpsseminarene var det vanskelig å identifisere posisjonene (Zeiner, 2014). I Trondheim er det tydelig at Selvhjelp Norge er i posisjon, med Vårres som den tydeligste utfordreren.

Sett under ett er det likevel lite som skiller aktørenes forståelse av selvhjelp i 1995 og 2014. Inntrykket er at Nasjonal plan for selvhjelp og Selvhjelp Norge i liten grad har lagt føringer på aktørenes arbeid. Intervjuene med andre sivilsamfunnsaktører som driver selvhjelpsrelatert virksomhet på 2010-tallet, forsterker dette inntrykket. Det kan, med andre ord, synes som om nasjonal plan og Selvhjelp Norge i liten grad har bidratt til å koordinere innsatsen til frivillige organisasjoner som driver selvhjelpsrelatert arbeid. Sett på bakgrunn av det uttalte behovet for slik koordinering (se for eksempel oppsummering av posisjonene i Helsedirektoratet, 2014b, s. 9) kan dette synes paradoksalt. I det følgende vil jeg derfor se nærmere på hvem som ønsket - og ønsker - koordinering av selvhjelpsarbeidet, og hva slags koordinering som etterspørres.

\section{Hvem ønsker koordinering?}

Utgangspunktet for seminarrekken Selvhjelp på norsk var et opplevd behov for å knytte kontakt mellom aktører som drev selvhjelpsrelatert arbeid (Nilsen \& Talseth, 1995). Oppblomstringen av selvhjelpsgrupper og selvhjelpsorganisasjoner fra 1970-tallet og utover hadde forandret et felt som i all hovedsak hadde vært dominert av AA-bevegelsen og 12-trinnsprogrammet. Et økende antall organisasjoner inkluderte selvhjelp og likepersonsarbeid i sitt repertoar, noe som naturlig nok medførte større variasjon i aktører, innretning og arbeidsmåter (Zeiner, 2014). Feltet var «uorganisert (...) uoversiktlig og mangfoldig» (Sandvik, 1996a, s. 27), noe som kunne bidra til en opplevelse av selvhjelp som lite tilgjengelig (Sosialog helsedirektoratet, 2004). 
Innleggene på selvhjelpsseminarene tyder på at det først og fremst var Studiesenteret, selvhjelpsorganisasjonene og brukerorganisasjonene som så behovet for mer koordinering, mens de øvrige deltakerne var mer opptatt av samarbeid mer profesjonene, praktisk organisering, med videre. Det handler blant annet om å forstå selvhjelp som aktivitet, og om avgrensning mot andre, lignende aktiviteter. Begrunnelsene er imidlertid ikke de samme. For selvhjelps- og brukerorganisasjonene synes det $\mathrm{i}$ stor grad å handle om synlighet eller tilgjengelighet (se for eksempel $\mathrm{K}$ (Anonyme Alkoholikere), 1995). Når det er vanskelig å få oversikt over hva selvhjelpstilbudet består i, og hvem som driver selvhjelpsrelatert virksomhet, vil det også være vanskelig for aktørene å etablere kontakt med potensielle deltakere, med offentlige myndigheter, eller med hjelpeapparatet. Studiesenteret synes på sin side å være mest opptatt av å avklare hva selvhjelp er og hva det ikke er, og føyer seg således inn i rekken av forskere som har forsøkt å finne mer entydige definisjoner av selvhjelp (se for eksempel Borkman, 1999; Karlsson, 2006; Katz \& Bender, 1976; Lavoie \& Gidron, 2014; Mehlbye \& Nygaard Christoffersen, 1992; Raineri, 2017; Sagarin, 1969). Studiesenteret beskriver den økte interessen for selvhjelp som et «tveegget sverd»; den «kan bidra til å skape muligheter for utvikling av selvhjelp, men interessen kan også bidra til å omforme selvhjelpen og endre dens karakter» (Hjemdal et al., 1998, s. 13). Ideen er at en sterkere koordinering av selvhjelpsfeltet er nødvendig for å forhindre at selvhjelpsideen koopteres og omformes.

Når arbeidet med å etablere LINK Trondheim starter opp i 2012, har Selvhjelp Norge bygget opp en organisasjon som har erfaring med å etablere møteplasser i samarbeid med lokale myndigheter. Som vi har sett, bidro både LINK-modellen og Selvhjelp Norges prinsipper for selvorganisert selvhjelp til å legge føringer for prosessen; en koordinering som deltakerne i prosessen i ulik grad ønsker velkommen. I motsetning til selvhjelpsseminarene på 1990-tallet synes det ikke lenger være et opplevd behov for koordinering blant organisasjonene som driver selvhjelpsrelatert virksomhet. Vårres, som er den av deltakerne som klarest definerer selvhjelp som del av sin kjernevirksomhet, er minst mottakelig for Selvhjelp Norges koordinering. Intervjuene med andre selvhjelpsaktører som ikke var involvert i etableringen av LINK Trondheim, tegner et lignende 
bilde. Ingen av dem gir uttrykk for at nasjonal plan eller Selvhjelp Norge er førende for deres virksomhet.

De av deltakerne i arbeidet med LINK Trondheim som ikke definerer selvorganisert selvhjelp som del av sin kjernevirksomhet, er overveiende mer positive til Selvhjelp Norges rolle som koordinator. På spørsmål om hva Selvhjelp Norge generelt, og LINK Trondheim spesielt, kan bidra med for deres virksomhet, peker både SiT Råd og Batteriet på at det muliggjør en arbeidsdeling mellom organisasjonene. For SiT Råd handler det om at igangsetting og drift av selvhjelpsgrupper i egen regi har vist seg å være krevende, og de ser for seg at de kan henvise studenter som ønsker å delta i slike grupper til LINK Trondheim. For Batteriet handler det om en erkjennelse av at individuelle endringsprosesser kan være en forutsetning for kollektive endringsprosesser. Vi «har jo mye fokus på organisering (...), snakke en sak til politikere og sånn, mens mange bærer jo med seg ting som det er viktig å ordne opp i eget liv». Jeg «tenker at mange ganger, så hadde det vært nyttige for (...) denne gruppen å hatt fora som (...) har litt mer den terapeutiske tilnærmingen» (Intervju Batteriet 29.10.2014). Selvhjelp Norge og LINK Trondheim har tilbud som deres medlemmer kan benytte seg av, men som ikke konkurrerer med disse organisasjonenes virksomhet. Det står dermed lite på spill for disse organisasjonene, og de kan derfor lettere akseptere Selvhjelp Norge som premissleverandør. For dem er derfor andre kjennetegn ved LINK Trondheim, så som fysisk utforming og beliggenhet, mer viktig enn hva slags prinsipper for selvhjelp som skal ligge til grunn for virksomheten.

At ønsket om og behovet for koordinering synes å være mindre etter nasjonal plan for selvhjelp, kan ha flere årsaker. I det videre vil jeg undersøke én, nemlig om den formen for koordinering som organisasjonene etterspurte på 1990-tallet, var av en annen art enn den som tilbys gjennom nasjonal plan og Selvhjelp Norge. Den nasjonale satsingen bygger på Studiesenterets diagnose av selvhjelpsfeltet som fragmentert (Helsedirektoratet, 2014b). Er årsaken til at frivillige organisasjoner i liten grad støtter seg på Selvhjelp Norge, at den nasjonale planen Selvhjelp Norge skal implementere, er basert på en feilaktig diagnose av selvhjelpsfeltet? 


\section{Hva slags koordinering er etterspurt?}

Et grunnleggende premiss i nasjonal plan for selvhjelp fra 2004 er at det $\mathrm{i}$ «det videre arbeidet med styrking av selvhjelpsfeltet vil (...) være viktig å klargjøre begrepet» (Sosial- og helsedirektoratet, 2004, s. 9). Innleggene fra selvhjelpsseminarene på 1990-tallet tyder imidlertid ikke på at begrepsavklaring stod høyt på deltakernes dagsorden. Selv om flere tar til orde for en sterkere koordinering av selvhjelpsfeltet, er det kun to av dem som ser for seg at dette skal skje gjennom begrepsavklaring: Studiesenteret, som understreker behovet for å etablere en «felles forståelse» av hva selvhjelp er og av feltets identitet (Hjemdal et al., 1998, s. 264), og Angstringen, som mener det er behov for «en felles ideologisk forståelse av hva selvhjelp er» (Godager, 1996, s. 16). Begge argumenterer for et mer formalisert samarbeid, hvor en «sentral koordinerende instans» (Hjemdal et al., 1998) har ansvar for å gi økonomisk, organisatorisk og faglig bistand til selvhjelpsgrupper og selvhjelpsorganisasjoner. Den koordinerende instansen skal både bidra til «økonomisk koordinering på feltet»og til å «samle trådene og sikre at prosjekter på selvhjelpsfeltet samarbeider» (Godager, 1996, s. 20).

Andre aktører har andre foretrukne samarbeidsmodeller. I seminarinnleggene er det særlig to som skiller seg ut: clearinghouse og praksisnettverk. Et clearinghouse samler, klassifiserer og distribuerer informasjon (Merriam-Webster, udatert). Modellen, slik den beskrives av et AA-medlem (Lisæth, 1995), innebærer ikke begreps- eller metodeutvikling, men et systematisk informasjonsarbeid for å nå ut til et bredere publikum. Et clearinghouse skal organisere og videreformidle informasjon fra selvhjelpsgrupper og selvhjelpsorganisasjoner om målgrupper, tematikk, arbeidsform og organisering. Sorg og omsorg lanserer på sin side ideen om et «nettverk for kontakt og utveksling, for utvikling og utveksling av kunnskap og erfaringer» (Sandvik, 1996a, s. 27). Modellen kan minne om praksisnettverket; en gruppe mennesker som er opptatt av samme fagfelt eller problem, og som tilegner seg kunnskap og ekspertise gjennom kontinuerlig interaksjon med gruppen (Pyrko, Dörfler \& Eden, 2017; Wenger, McDermott \& Snyder, 2002). Målet er læring, ikke styring. Sorg og omsorg er skeptisk til ideen om en 
«sentral koordinerende instans» (jf. Godager, 1996; Hjemdal et al., 1998), og mener at en slik modell neppe kan implementeres «på en slik måte at selvhjelpsfeltet kan utvikle seg fritt, og uten at selvhjelpens særpreg trues» (Sandvik, 1996a, s. 27).

Nesten to tiår senere, i Trondheim, koordinerer Vårres et nettverk hvis formål er å formidle kontakt mellom selvhjelpsgrupper og potensielle deltakere. Nettverket synes å være løsere og mindre forpliktende enn både clearinghousemodellen og praksisnettverket. Koordinatorfunksjon, som Vårres overtok omtrent på samme tid som LINK Trondheim åpnet dørene, er tilsynelatende begrenset til å ta imot og formidle informasjon fra deltakerne i nettverket (Vårres, udatert). Vårres signaliserer at de ser større behov for denne nettverksfunksjonen enn for LINK Trondheim, men innrømmer samtidig at det er vanskelig å rekruttere medlemmer i nettverket (Intervju Vårres 27.10.2014). SiT Råd og Batteriet er ikke opptatt av nettverksfunksjonen, men fremhever clearinghousefunksjonen. Ingen av dem har sterke meninger om innholdet i denne funksjonen, men understreker behovet for et sted hvor man kan henvende seg dersom man ønsker å delta i en selvhjelpsgruppe eller ønsker mer informasjon om selvhjelp.

Den reviderte nasjonale planen for selvhjelp skisserer verken en nettverksmodell eller en clearinghousemodell (Helsedirektoratet, 2014b). Den opprinnelige planen tar utgangspunkt i en nettverkstankegang, og har som ambisjon å «bidra til at ulike aktører blir aktive deltakere i utvikling av selvhjelpsarbeidet» (Sosial- og helsedirektoratet, 2004, s. 12). Den reviderte planen bygger på en mer rendyrket kompetansesentermodell, med Selvhjelp Norge som forvalter og formidler av verktøyet selvorganisert selvhjelp. Samtidig ser vi at Selvhjelp Norge retter sin virksomhet mer mot offentlige myndigheter, tjenestene og profesjonene, og mindre mot selvhjelps- og brukerorganisasjonene (Zeiner, 2014). Det virker med, med andre ord, som om Selvhjelp Norge har forlatt ambisjonen om å fungere som en koordinerende enhet for frivillige organisasjoner som driver selvhjelpsrelatert virksomhet. Dette reiser spørsmålet om det er organisasjonene som ikke har bruk for Selvhjelp Norge, eller om det er Selvhjelp Norge som ikke har bruk for organisasjonene. 


\section{Hva er «felles» for selvhjelpsaktørene?}

Et strategisk felt er organisert rundt felles interesser (Fligstein \& McAdam, 2012). Aktørene på et strategisk felt kan ha ulike ressurser og ulike forståelser om hva som er og bør være feltets spilleregler. Interaksjonene mellom aktørene kan derfor være preget av større eller mindre grad av konflikt. På et felt vil imidlertid aktørene strides om noe de har til felles (Bourdieu \& Wacquant, 1992; Broady, 1991; DiMaggio \& Powell, 1983; Fligstein \& McAdam, 2012). Den nasjonale satsingen på selvhjelp har som utgangspunkt at det er selvhjelp som metode eller verktøy som er det felles limet mellom aktørene. I den første nasjonale planen kommer dette til uttrykk ved at aktørene inviteres til metodeutvikling (Sosial- og helsedirektoratet, 2004), i den reviderte planen ved at de presenteres for et verktøy de kan ta i bruk (Helsedirektoratet, 2014b).

Som vi har sett, har det over tid vært liten interesse blant selvhjelpsog brukerorganisasjonene for å delta i metodeutvikling og begrepsavklaring. Den manglende interessen kan forklare hvorfor Selvhjelp Norge etter få års drift beveger seg bort fra nettverksmodellen, og begynner å kalle seg et kompetansesenter. «Det er (...) ikke naturlig», konkluderer den reviderte planen, «å snakke om et eget selvhjelpsfelt» (Helsedirektoratet, 2014b, s. 11). Snarere beskriver den reviderte planen selvhjelp som en arbeidsmåte og en forståelse som kan tas i bruk av aktører på ulike områder. Enkeltmennesker, tjenesteapparat og utdanningsinstitusjoner pekes ut som målgrupper for Selvhjelp Norges formidlingsarbeid (Helsedirektoratet, 2014b), samtidig understrekes det at selvhjelpsgrupper i bruker- og interesseorganisasjoner og selvhjelpsorganisasjoner også «vil (...) ha sin naturlige plass» (Helsedirektoratet, 2014b, s. 13).

Den reviderte planen holder fast ved en forståelse av selvhjelp som et samlende verktøy metode. Men rapportene fra selvhjelpsseminarene (Nilsen \& Talseth, 1995; Sandvik, 1996b), og intervjuene med involverte aktører i LINK Trondheim og andre selvhjelpsaktører, tyder på at det ikke primært er metoden eller verktøyet selvhjelp som utgjør aktørenes felles interesse. Som det fremkommer av innleggene på selvhjelpsseminarene, er aktørene stort sett er enige om de overordnede prinsippene for selvhjelp, og mindre interessert i å definere metoden i mer detalj (Zeiner, 2014). Litteraturen om selvhjelpsgrupper bekrefter inntrykket av at det 
er relativt enkelt å identifisere noen grunnleggende kjennetegn ved selvhjelp, og vanskeligere å gi en entydig definisjon av hva selvhjelp er (se for eksempel Katz \& Bender, 1976; Raineri, 2017). Årsaken kan være at arbeidet $\mathrm{i}$ en selvhjelpsgruppe nødvendigvis vil inkludere en rekke formaliserte og uformaliserte praksiser som vil være lokale, kontekstuelle og spesifikke for den enkelte gruppens formål og deltakere (jf. Scott, 1998). I en slik situasjon vil en entydig definisjon enten være svært overordnet og skjematisk, noe som vil kreve lokale tilpasninger, eller ha et svært begrenset nedslagsfelt, noe som også vil begrense dens verdi.

Behovet for å rekruttere medlemmer og deltakere er den tydeligste felles interessen organisasjonene har. Medlemmene og gruppedeltakerne er organisasjonenes raison d'être, og deres behov og interesser former organisasjonenes tilbud. Innhold og organisering av selvhjelpsarbeidet «har med hva som har fungert, våre medlemmers behov» (Intervju frivillig organisasjon 1, 23.01.2013). For frivillige organisasjoner har medlemmene ofte også betydning for organisasjonenes mulighet for å opprettholde og finansiere tilbudet sitt. På den ene siden er det slik at dersom mennesker som kan ha behov for å delta i selvhjelpsgrupper, ikke «kjenner til tilbudene (...) forsvinner tilbudene etter hvert» (Vårres 27.10.2014). På den andre siden finansierer mange frivillige organisasjoner større eller mindre deler av sin virksomhet gjennom statlige tilskudd. Offentlige tilskudd til frivillige organisasjoner har gjerne fordelingskriterier knyttet til medlemstall og nasjonal utbredelse (Helsedirektoratet, 2014a), slik at manglende rekruttering eller nedleggelse av tilbud vil kunne påvirke organisasjonenes økonomi negativt.

Det er derfor viktig å komme i kontakt med potensielle deltakere i selvhjelpsgrupper, og med profesjoner og offentlige tjenester som kan formidle kontakt mellom sine pasienter og brukere og selvhjelpsorganisasjonene og gruppene. Dette kan forklare hvorfor flere av bruker- og selvhjelpsorganisasjonene etterlyser et nasjonalt eller lokalt clearinghouse for selvhjelp. Det kan også forklare hvorfor organisasjonene er lite interessert i å delta i Selvhjelp Norges utviklingsarbeid. Intervjuene med de frivillige organisasjonene tyder på at Selvhjelp Norge oppfattes som en promotør av en bestemt praksis, og ikke som en upartisk formidler av kunnskap og informasjon om selvhjelp. Dette kommer blant annet til uttrykk i den 
reviderte planen for selvhjelp, som ikke bare gir en mer detaljert beskrivelse av hva selvhjelp er, men som også slår fast at «[s]elvhjelpsgrupper med ulike problem eller diagnoser [erfaringsmessig] har mange fordeler» (Helsedirektoratet, 2014b, s. 13). Når planen fastslår at «[e]rfaring viser» (Helsedirektoratet, 2014b, s. 13), er det ikke de frivillige organisasjonenes erfaringer det vises til. Tvert imot vektlegger disse at felles diagnose, problem eller lignende gir felles erfaringer; at det er «viktig å speile seg i folk med samme bakgrunn» (Intervju frivillig organisasjon 4 23.01.2013).

Budskapet om at grupper kan og bør settes sammen på tvers, utfordrer ideen om selvhjelp som en aktivitet av og for medlemmer, og dermed også de frivillige organisasjonenes finansieringsmodell. I motsetning til et clearinghouse, som blant annet formidler kontakt mellom personer med et gitt problem og organisasjoner eller selvhjelpsgrupper som er organisert rundt dette problemet, innebærer modellen med problemoverskridende grupper at koblingen til bruker- og interesseorganisasjonen svekkes. Vårres sine erfaringer fra opprettelsen av LINK Trondheim er illustrerende. Her var det behovet for en nøytral, ikke-problemspesifikk, møteplass som var den sentrale begrunnelsen for at Vårres ikke kunne drifte LINK Trondheim (Intervju distriktskontor 29.09.2014; intervju Trondheim kommune 27.10.2014; intervju Batteriet 29.10.2014; intervju Vårres 27.10.2014). Selvhjelp Norge vil, med andre ord, ikke bidra til, eller gjøre det enklere for organisasjonene, å rekruttere medlemmer og deltakere. I stedet henvender organisasjonene seg til andre aktører som arbeider med lignende problematikk eller innenfor samme felt. På spørsmål om hvem som er organisasjonenes viktigste samarbeidspartnere, viser de gjerne til offentlige tjenester og andre frivillige organisasjoner og sammenslutninger som har tilbud til samme brukergrupper. Dette kan tyde på at de forstår felles interesse som felles brukergruppe eller felles problem- eller politikkområde, og ikke felles metodikk eller arbeidsmåter.

\section{Diskusjon}

I nasjonal plan for selvhjelp fra 2014 står det at «[u]ten en nasjonal enhet eller et kompetansesenter ville arbeidet med selvorganisert selvhjelp forblitt fragmentert og ufullstendig utnyttet» (Helsedirektoratet, 2014b, s. 9). 
På tross av at Selvhjelp Norge er etablert som nasjonalt kompetansesenter for selvhjelp, har organisasjonen tilsynelatende hatt liten innflytelse på frivillige organisasjoner som har etablert ulike selvhjelpstilbud. Tvert imot, er inntrykket fra denne undersøkelsen at det er mindre samhandling mellom organisasjonene i dag enn det var for 20 år siden. Mens de på 1990-tallet søkte sammen for å utveksle erfaringer fra selvhjelpsarbeidet, synes de i dag i større grad å orientere seg mot andre organisasjoner som arbeider med samme brukergrupper eller lignende problematikk. Sett fra de frivillige organisasjonenes side kan det, med andre ord, synes som om selvhjelpsarbeidet er minst like fragmentert i 2018 som det var på midten av 1990-tallet.

Det er i så fall interessant at selvhjelpsområdet har en annen utvikling enn frivillighetsområdet mer generelt. Mens Sivesind og kolleger i 2002 observerte at frivillig sektor sjelden identifiserte seg som en sektor (Sivesind, Lorentzen, Selle \& Wollebæk, 2002), konkluderer Sivesind i 2008 med at det har «skjedd mye som har bidratt til å styrke den felles identiteten til den norske frivillige sektoren på svært kort tid» (Sivesind, 2008, s. 53). Ulike faktorer, som for eksempel innføring av moms på tjenester, etablering av et satellittregnskap for frivillig arbeid og etableringen av et frivillighetsregister, har bidratt til standardisering og formalisering (Sivesind, 2008; Strømsnes, 2013). Ifølge Sivesind har den statlige politikken på frivillighetsområdet bidratt til at organisasjonene «så at de hadde felles økonomiske rammevilkår og at det fantes rom for ytterligere forbedringer» (Sivesind, 2008, s. 52). Nasjonal plan for selvhjelp synes, på sin side, ikke å ha bidratt til å fremme en felles identitet. Tvert imot er inntrykket at organisasjonene, i møtet med nasjonal plan og Selvhjelp Norge, har behov for å understreke sin egenart.

At 20 års begrepsavklaringsarbeid ikke har bidratt til en felles forståelse av hva selvhjelp er og bør være, kan tyde på at tiltakene i nasjonal plan har vært basert på en feilaktig diagnose. Snarere enn fragmentert og «identitetsmessig» presset kan det hende at mangfold er et kjennetegn ved en fungerende selvhjelpsbevegelse. Sorg og omsorg uttrykte det slik i 1996: «Selvhjelpsfeltet er først og fremst et bruker- og deltakerfellesskap. Det er ikke sikkert at feltet som sådan bør eller trenger å bli organisert, eller trenger å utvikle en bevissthet om feltets egenart ut over de erfaringer 
som gjøres i feltet» (Sandvik, 1996a, s. 27). Dette er en påstand som finner gjenklang i den akademiske litteraturen om selvhjelpsgrupper. Borkman (1999), for eksempel, sammenligner selvhjelpsgrupper med ville blomster; en samling større og mindre grupper og organisasjoner som skaper sin egen, erfaringsbaserte kunnskap og som finner en form tilpasset denne kunnskapen. I denne tolkningen er det en styrke heller enn en svakhet at organisasjonene og gruppene har ulike formål, ideologier og tilnærminger. Det er et tegn på en bevegelse som kan tilpasse seg og respondere på deltakernes og samfunnets behov.

Dersom dette stemmer, er det problematisk at nasjonal plan for selvhjelp fremmer en bestemt forståelser av selvhjelp heller enn å representere og vise frem mangfoldet av tilnærminger. Som vi har sett, er det Angstringens forståelse av selvhjelp som ligger til grunn til for Selvhjelp Norges arbeid. I motsetning til Frivillighet Norge er Selvhjelp Norge da heller ikke et samarbeidsorgan for frivillige organisasjoner og andre som driver selvhjelpsarbeid. Selvhjelp Norge drives av Norsk selvhjelpsforum, som ble dannet i 1998 av to personer fra Angstringen, en psykolog med erfaring fra samarbeid med Angstringen samt en representant fra Studiesenteret (Feiring, 2014). Når Selvhjelp Norge ikke oppleves å representere organisasjonen som driver selvhjelpsrelatert arbeid, kan den heller ikke fungere som et bindeledd mellom frivillige organisasjoner og tilgrensende felt.

Nasjonal plan for selvhjelp har bidratt til å omforme selvhjelpsfeltet, men til dels på andre måter enn det som ble forutsatt i den opprinnelige planen fra 2004. Mens bruker- og interesseorganisasjoner var sentrale aktører på 1990-tallet, er de i dag mindre tilbøyelige til å posisjonere seg og interagere med hverandre på grunnlag av en felles forståelse av et selvhjelpsfelt. I dette kapittelet har jeg diskutert én årsak, nemlig at Selvhjelp Norge ikke tilbyr ressurser som er sentrale nok for organisasjonene til at de velger å posisjonere seg i kampen om dem. Et strategisk felt eksisterer når aktørenes strides om noe de har til felles (Bourdieu \& Wacquant, 1992; Fligstein \& McAdam, 2012). Det betyr, blant annet, at feltets grenser ikke vil være stabile, men forandre seg avhengig av aktørenes definisjon av situasjonen og hva som står på spill. Vi har sett at selvhjelpsfeltet har endret seg over tid. Denne undersøkelsen gir ikke grunnlag for å fastslå 
om det er Selvhjelp Norge som har vendt seg bort fra organisasjonene, eller om det er organisasjonene som har vendt seg bort fra Selvhjelp Norge. Av Selvhjelp Norges årsrapporter kan vi imidlertid lese at andre aktører, så som velferdstjenester og profesjoner, frivilligsentraler og kommuner og andre offentlige myndigheter, er blitt viktigere (Zeiner, 2014). Dette reiser spørsmålet om vi ser konturene av et nytt selvhjelpsfelt, som i større grad organiseres rundt andre aktører, interesser og ressurser enn aktørene på frivillighetsfeltet.

\section{Referanser}

Batteriet. (udatert). Om Batteriet. Hentet 15. august 2018 fra http://www.batteriet.no/ om-batteriet/

Borkman, T. (1999). Understanding self-help/mutual aid: Experiential learning in the commons. New Brunswick, New Jersey and London: Rutgers University Press.

Bourdieu, P. (1993). Sociology in question. London: Sage.

Bourdieu, P. \& Wacquant, L. J. (1992). An invitation to reflexive sociology. Chicago: University of Chicago Press.

Broady, D. (1991). Sociologi och epistemologi. Om Pierre Bourdieus författarskap och den historiska epistemologin (2 korr.uppl.). Stockholm: HLS Förlag.

DiMaggio, P. \& Powell, W. W. (1983). The iron cage revisited: Collective rationality and institutional isomorphism in organizational fields. American Sociological Review, 48(2), 147-160.

Feiring, M. (2013). Politicisation of self-help in Norway. I L. Nicolaou-Smokoviti; H. Sünker, J. Rozanova \& V. Pekka Economou (Red.), Citizenship and social development. Citizen participation and community involvement in social welfare and social policy. Frankfurt am Main: Peter Lang Publishing Groups.

Fligstein, N. \& McAdam, D. (2012). A theory of fields. Oxord: Oxford University Press.

Godager, E. V. (1996). Innlegg ved Eli Vogt Godager, Angstringen Oslo. I O. Sandvik (Red.), Selvhjelp på norsk. Rapport fra selvhjelpsseminaret 26.-28 april 1996. Oslo: Høgskolen i Oslo, Avdeling for økonomi-, kommunal- og sosialfag.

Goksøyr, T. (1995). Selvhjelp - en ideologi. I S. Nilsen \& S. Talseth (Red.), Selvhjelp på norsk: Rapport fra selvhjelpsseminaret 12.-13. februar 1995. Oslo: NotaBene, Ø.K.S-rapport 95:6.

Gotaas, N. (2012). Etablering og igangsetting av selvhjelpsgrupper. NIBR-rapport 2012:8. Oslo: Norsk institutt for by- og regionforskning.

Helsedepartementet. (2003). Resept for et sunnere Norge: Folkehelsepolitikken (St. meld. $n r .16$ (2002-2003)). Oslo: Helsedepartementet. 
Helse- og omsorgsdepartementet. (2005). Proposisjon til Stortinget for budsjettåret 2006 (Prop. 1 S 2005-2006). Oslo: Helse- og omsorgsdepartementet.

Helsedirektoratet. (2014a). Faglighet og frivillighet: En gjennomgang av tre tilskuddsordninger for frivillig rusmiddelforebygging, Oslo: Helsedirektoratet.

Helsedirektoratet. (2014b). Nasjonal plan for selvhjelp 2014-2018. Oslo: Helsedirektoratet.

Hjemdal, O. K. (1996). Status for selvhjelpsfeltet. I O. Sandvik (Red.), Selvhjelp på norsk. Rapport fra selvhjelpsseminaret 26.-28. april 1996. Oslo: Høgskolen i Oslo, Avdeling for økonomi-, kommunal- og sosialfag.

Hjemdal, O. K., Nilsen, S. \& Seim, S. (1998). Selvhjelp: Kunsten å løfte seg etter håret. Oslo: Cappelen Akademisk Forlag.

Johannessen, R. (1995). Hva forstår jeg med selvhjelp? I S. Nilsen \& S. Talseth (Red.), Selvhjelp på norsk: Rapport fra selvhjelpsseminaret 12.-13. februar 1995. Oslo: NotaBene, Ø.K.S-rapport 95:6.

K. (Anonyme Alkoholikere) (1995). Innlegg i debatt om selvhjelpsgrupper. I S. Nilsen \& S. Talseth (Red.), Selvhjelp på norsk: Rapport fra selvhjelpsseminaret 12.-13. februar 1995. Oslo: NotaBene, Ø.K.S-rapport 95:6.

Karlsson, M. (2006). Självhjälpsgrupper: teori och praktik. Lund: Studentlitteratur.

Katz, A. H. \& Bender, E. I. (1976). Self-help groups in Western society: History and prospects. The Journal of Applied Behavioral Science, 12(3), 265-282.

Kurunmäki, J. (2012). Begreppshistoria. I G. Bergström \& K. Boréus (Red.), Textens mening och makt. Lund: Studentlitteratur.

Lavoie, F. \& Gidron, B. (2014). Self-help and mutual aid groups: International and multicultural perspectives. New York: Routledge.

Lisæth, A. (1995). AAs struktur. I S. Nilsen \& S. Talseth (Red.), Selvhjelp på norsk: Rapport fra selvhjelpsseminaret 12.-13. februar 1995. Oslo: NotaBene, Ø.K.Srapport 95:6.

Mehlbye, J. \& Nygaard Christoffersen, M. (1992). Selvhjolpsgrupper - omfang, karakter og erfaringer. København: AKF Forlaget.

Merriam-Webster. (udatert). Clearinghouse. Hentet 17. august 2018 fra https://www. merriam-webster.com/dictionary/clearinghouse

Munn-Giddings, C. \& Borkman, T. (2005). Self-help/mutual aid as a psychosocial phenomenon. I S. Ramon \& J. Williams (Red.), Mental health at the crossroads. The promise of the psychosocial approach. Aldershot: Ashgate Publishing.

Nilsen, S. \& Talseth, S. (Red.). (1995). Selvhjelp på norsk: Rapport fra selvhjelpsseminaret 12.-13. februar 1995 Oslo: NotaBene, Ø.K.S-rapport 95:6.

Pyrko, I., Dörfler, V. \& Eden, C. (2017). Thinking together: What makes communities of practice work? Human Relations, 7o(4), 389-409.

Raineri, M. L. (2017). Relational social work and mutual/self-help groups. Relational Social Work, 1(1), 19-38. 
Rambøll Management. (2014). Evaluering av Selvhjelp Norge sine distriktskontorer. Oslo: Rambøll Management.

Sagarin, E. (1969). Odd man in: Societies of deviants in America. New York: Quadrangle Books.

Sandvik, O. (1995). Hva forstår vi med selvhjelp? I S. Nilsen \& S. Talseth (Red.), Selvhjelp på norsk: Rapport fra selvhjelpsseminaret 12.-13. februar 1995. Oslo: NotaBene, Ø.K.S-rapport 95:6.

Sandvik, O. (1996a). Innlegg v/Oddbjørn Sandvik, Sorg og omsorg. I O. Sandvik (Red.), Selvhjelp på norsk. Rapport fra selvhjelpsseminaret 26.-28. april 1996. Oslo: Høgskolen i Oslo, Avdeling for økonomi-, kommunal- og sosialfag.

Sandvik, O. (Red.). (1996b). Selvhjelp på norsk 2: Rapport fra selvhjelpsseminaret 26.-28. april 1996. Oslo: Høgskolen i Oslo, Avdeling for økonomi-, kommunal- og sosialfag.

Scott, J. C. (1998). Seeing like a state: How certain schemes to improve the human condition have failed. New Haven and London: Yale University Press.

Seebohm, P., Munn-Giddings, C. \& Brewer, P. (2010). What's in a name? A discussion paper on the labels and location of self-organising community groups, with particular reference to mental health and black groups. Mental Health and Social Inclusion, 14(3), 23-29. https://doi.org/doi:10.5042/mhsi.2010.0441

Selvhjelp Norge. (2009). Årsmelding 2008. Selvhjelp Norge. Hentet fra http://www. selvhjelp.no/filestore/SelvhjelpNorge_Rapport2009.pdf

Selvhjelp Norge. (2010). Selvhjelp Norge. Rapport for virksomheten i 20o9. Selvhjelp Norge. Hentet fra http://www.selvhjelp.no/filestore/Rapport_2010_Hdir_KP_ DK_endelig.pdf

Selvhjelp Norge. (2011). Selvhjelp Norge. Rapport for virksomheten i 2010. Selvhjelp Norge. Hentet fra http://www.selvhjelp.no/filestore/Rapport_2010_Hdir_KP_ DK_endelig.pdf

Selvhjelp Norge. (2013). Årsrapport 2012. Nasjonalt kompetansesenter for selvorganisert selvhjelp. Selvhjelp Norge. Hentet fra http://www.selvhjelp.no/ filestore/rsrapport2012SelvhjelpNorge120405.pdf

Selvhjelp Norge. (2016). Selvhjelp Norge. Distriktskontorens arbeid i 2015. Selvhjelp Norge. Hentet fra http://www.selvhjelp.no/no/Om_oss/Arsrapporter/ Årsrapport+2015+-+Selvhjelp+Norge.b7C_wlLSZn.ips

Selvhjelp Norge. (udatert-a). Arbeid med etablering av en lokal møteplass for selvorganisert selvhjelp. Hentet 27. februar 2015 fra http://www.selvhjelp.no/ no/Distriktskontorer/More_og_Romsdal_Nord-_og_Sor-Trondelag/Hva_ skjer+/Trondheim $+19 .+$ og $+20 .+$ september $\% 3 \mathrm{~A}+$ Arbeid + med + etablering + av + en $+m \% C_{3} \%$ B8teplass+for+selvorganisert+selvhjelp+i.b7C_wlnM5q.ips

Selvhjelp Norge. (udatert-b). Møtested for selvorganisert selvhjelp i Trondheim under utvikling. Hentet 27. februar 2015 fra http://www.selvhjelp.no/no/ 
Distriktskontorer/More_og_Romsdal_Nord-_og_Sor-Trondelag/Hva_skjer+/M\% $\mathrm{C}_{3} \%$ B8tested + for + selvorganisert+selvhjelp $+\mathrm{i}+$ Trondheim + under+utvikling. b7C_wlnQ2j.ips

SiT. (udatert). Mestringskurs. Hentet 15. oktober 2015 fra https://www.sit.no/ kurs/!mestringskurs

Sivesind, K. H. (2008). Halveis til Soria Moria. Ikke-kommersielle velferdstjenester, politikkens blinde flekk? Rapport 2008:3. Hentet fra https://brage.bibsys.no/xmlui/ handle/11250/2441546

Sivesind, K. H., Lorentzen, H., Selle, P. \& Wollebæk, D. (2002). The voluntary sector in Norway. Composition, changes and causes. Institutt for samfunnsforskning. Hentet fra https://www.researchgate.net/profile/ Per_Selle2/publication/238623378_The_Voluntary_Sector_in_Norway/ links/54118fibocf264cee28b3fdo.pdf

Sosial- og helsedepartementet. (1993). Lat ikkje graset gro att mellom grannar: Om videreføring av arbeidet med Frivillighetssentralene (St. meld. nr. 16 (1993-1994)). Oslo: Sosial- og helsedepartementet.

Sosial- og helsedirektoratet. (2004). Nasjonal plan for selvhjelp. Oslo: Sosial- og helsedirektoratet.

Strømsnes, K. (2013). Norsk frivillighetspolitik: Ny och enhetlig? I L. Trägårdh, L. S. Henriksen \& H. Hallin (Red.), Civilsamhället klämt mellan stat och kapital. Stockholm: SNS Förlag.

Talseth, S. (1995). Innlegg fra Angstringen. I S. Nilsen \& S. Talseth (Red.), Selvhjelp på norsk: Rapport fra selvhjelpsseminaret 12.-13. februar 1995. Oslo: NotaBene, Ø.K.S-rapport 95:6.

Velferdsalliansen. (udatert). Om oss. Hentet 15. august 2018 fra https:// velferdsalliansen.no/om-oss

Vårres. (2017). Vedtekter Hentet 15. august 2018 fra https://www.varres.no/index. $\mathrm{php} /$ varres-brukerstyrt-senter/vedtekter

Vårres. (udatert). Selvhjelp Nord-Trøndelag. Hentet 30. oktober 2014 fra https:// www.varres.no/index.php/brukere-parorende/nord-trondelag/selvhjelp-nordtrondelag

Wenger, E., McDermott, R. A. \& Snyder, W. (2002). Cultivating communities of practice: A guide to managing knowledge. Boston, Mass.: Harvard Business Press.

Zeiner, H. H. (2014). Konsolidering på et fragmentert felt. NIBR-notat, 2014(105), $1-44$. 

KAPITTEL 8

\title{
Selvhjelp i grenseland - en ny type helsebevegelse?
}

\author{
Ånund Brottveit \\ KIFO - Institutt for kirke-, regions- og livssynsforskning \\ Marte Feiring \\ Fakultet for helsevitenskap, OsloMet -Storbyuniversitetet
}

Hilde Hatleskog Zeiner

By- og regionforskningsinstituttet NIBR, OsloMet -Storbyuniversitetet

\begin{abstract}
In this chapter, we study the Norwegian self-help activism in light of the idea of boundary work. We focus our attention on the Norwegian self-help forum (NSF) and Self-Help Norway (SN) as representatives of a specific direction within the diversity of self-help organizations that grew up towards the end of the 20th century. NSF/SN stands out for their strategic cooperation with the authorities, while at the same time having adopted ideological positions when it comes to defining the phenomenon of self-help. We argue that the state-oriented self-help activism has been a unique Norwegian phenomenon, and probably also in an international context. The chapter is organized in several parts: After a short introduction, we describe empirically how the national self-help actors were met by quite different local communities. Secondly, we discuss whether this self-help activity represents civil society or a type of boundary work between civil society and the welfare state. As our third theme, we ask whether this new selfhelp activism in Norway, can be characterized as part of a social movement or more specifically a new type of health movement. Finally, we summarize how the development in self-help activism over the past 20 years has contributed to actualizing tensions and hybridity in the borderland between the national and local and between civil and state agency.
\end{abstract}

Keywords: boundary work, local community, social movement, health movement, self-help movement, civil society

Sitering av dette kapittelet: Brottveit, Å., Feiring, M., \& Zeiner, H. H. (2019). Selvhjelp i grenseland - en ny type helsebevegelse? I Å. Brottveit \& M. Feiring (Red.), Samarbeid om selvhjelp. En antologi om den nye selvhjelpsbevegelsen $i$ Norge (s. 191-212). Oslo: Cappelen Damm Akademisk. https://doi.org/10.23865/noasp.68.ch8 Lisens: CC BY 4.0 


\section{Innledning}

I denne antologien har vi studert ulike aspekter ved selvhjelp som fenomen. Vi har sett på samhandling og samarbeid mellom deltakere i ulike former for selvhjelpsgrupper og selvhjelpsorganisasjoner, mellom selvhjelpsorganisasjoner og profesjoner samt mellom selvhjelpsorganisasjoner og offentlige myndigheter. Samhandling er et grunnleggende trekk ved den type selvhjelpsaktivitet vi har sett på her. Det dreier seg for det første om mennesker som kommer sammen for å hjelpe seg selv i fellesskap med andre, og for å forme og omforme egen så vel som storsamfunnets forståelse av dem (Taylor \& Leitz, 2010). Samtidig vil et slikt samarbeid kunne bidra til å artikulere latente spenninger mellom ulike tilnærminger og forståelser av selvhjelp. Vi har berørt noen slike spenninger, blant annet mellom terapeutiske og politiske tilnærminger, mellom profesjoner og selvhjelpsaktører og mellom sivilsamfunnsaktører og offentlige myndigheter.

Dette kapittelet samler trådene. Vi starter med en empirisk gjennomgang av hvordan de nasjonale selvhjelpsaktørene møter ulike lokalsamfunn, små steder, mellomstore og store byer samt møter med spesialiserte helsetjenester på regionalt nivå.

Deretter analyserer vi det norske selvhjelpsarbeidet i lys av ideen om grensearbeid. Med utgangspunkt i Gieryns (1999) begrep om grensearbeid i vitenskapelig kontekst har Eyal (2013) laget en syntese mellom Latours teori om nettverk og hybriditet og Bourdius feltanalyse. Eyal lanserer grensearbeid som analytisk kategori for å studere det som skjer i rommet eller i nettverkene mellom mer eller mindre autonome felt, som for eksempel «det politiske feltet» (staten), «det medisinske feltet» eller «helse- og velferdsfeltet» (helse- og sosialtjenestene). Selvhjelpsaktivitet analyseres som et grensearbeid mellom flere etablerte felt og i grenseland mellom sivilsamfunn og velferdsstat.

De siste tiårene har det vært økt oppmerksomhet om hvordan ulike aktører fra mental helse til AIDS har drevet frem helsepolitiske, så vel som identitetspolitiske, endringer (Archibald, 2007; Brown \& Zavestoski, 2005; Klawiter, 2008; Taylor \& Leitz, 2010). Til og med en uttalt apolitisk organisasjon som AA har, gjennom sin betoning av alkoholisme som sykdom og ikke en moralsk brist, bidratt til endring i vår forståelse 
av og tilnærming til alkoholisme og andre former for avhengighet (Valverde, 1998). Denne typen organisasjoner kjennetegnes ved at de bringer kroppen og personlige erfaringer inn som et mobiliserings- og identitetsgrunnlag for sosiale bevegelser, de utfordrer eksisterende medisinsk og vitenskapelig kunnskap, og de engasjerer gjerne eksperter og profesjoner i kampen for anerkjennelse og et (bedre) behandlingstilbud.

Vi retter særlig oppmerksomheten mot Norsk selvhjelpsforum og Selvhjelp Norge og spør om de representerer en egen retning innenfor det mangfoldet av selvhjelpsorienterte organisasjoner som vokste frem mot slutten av det 20. århundret. Norsk selvhjelpsforum og Selvhjelp Norge skiller seg ut ved sitt strategiske samarbeid med de statlige myndighetene samtidig som de har inntatt sterke ideologiske posisjoner når det gjelder å definere hva som er innenfor og utenfor selvhjelpsbegrepet. Vi argumenterer for at den aktiviteten de representerer, er et unikt fenomen i norsk sammenheng, og trolig også i en bredere internasjonal kontekst. Samtidig understreker vi at det finnes andre selvhjelpsaktører som ikke deler den ideologiske posisjonen og som ikke ser det som et problem å kombinere selvhjelpsarbeid med interessepolitikk.

Deretter tar vi utgangspunkt i Katz' (1993) spørsmål om selvhjelpsaktivisme kan forstås som del av en sosial bevegelse, eller en sosial helsebevegelse, som Archibald (2010) omtaler det. Sosiale bevegelser er spesifikke sosiale og politiske prosesser, «identifisert som uformelle nettverk av individer og organisasjoner basert på en felles kollektiv identitet som mobiliserer rundt konfliktfylte temaer» (Diani \& Della Porta, 2009, s. 29, vår oversettelse).

På tross av sin utbredelse er selvhjelpsgrupper og -organisasjoner i liten grad tematisert i forskningslitteraturen om sosiale bevegelser (Taylor \& Leitz, 2010). I likhet med bevegelser som retter sin protest mot kulturelle, snarere enn materielle, autoritetssystemer (jf. Snow, 2004), har det individorienterte selvhjelpsarbeidet i stor grad gått under radaren. Ifølge Taylor og Leitz (2010) skyldes dette at selvhjelpsaktører og aktivister ikke oppfattes som bidragsytere til politisk eller institusjonell endring, når de ikke har en eksplisitt politisk agenda. Det har vært liten oppmerksomhet om at selvhjelpsarbeid ikke bare handler om personlig endring, men også kan sette deltakerne i stand tilå endre sine betingelser for aktiv deltakelse 
i samfunnet. Selvhjelpsaktører med tilknytning til Norsk selvhjelpsforum og Selvhjelp Norge har sagt at de ikke vil drive «interessepolitikk» og mener da at de ikke ser det som sin oppgave å slåss for rettighetene til spesifikke interessegrupper, for eksempel brystkreftrammede eller psykiatriske pasienter. På den annen side så har vi sett mange eksempler på at de har arbeidet politisk for å tilrettelegge for selvhjelpsgrupper - enten gjennom nasjonale politiske planer eller gjennom kommunale planer og beslutninger.

Dette kapittelet har følgende struktur: Først redegjør vi for hvordan lokalsamfunnet forholder seg til den nasjonale satsingen på selvhjelp med utgangspunkt i egen empiri. Deretter diskuterer vi selvhjelp som grensearbeid i randsonen mellom sivilsamfunn og velferdsstat. Vi trekker her veksler på forskning om sivilsamfunn i de skandinaviske velferdsstater. Vårt tredje tema er en drøfting av hvorvidt den nye norske selvhjelpsaktivismen kan karakteriseres som del av en sosial bevegelse eller mer spesifikt, som en sosial helsebevegelse. Vi oppsummerer med noen antakelser om utviklingen innen selvhjelpsarbeidet de siste 20 årene har bidratt til å aktualisere spenninger i grenseland mellom det nasjonale og det lokale og det politiske og det sivile.

\section{Nasjonale selvhjelpsaktivister møter lokalsamfunnet}

Vi har i denne boken sett på oppbyggingen av organisert selvhjelpsarbeid etter de nye selvhjelpsaktørenes prinsipper i ulike lokalsamfunn og regioner. Prosessene gir innsikt i lokalt sosialt entreprenørskap, konkrete eksempler på offentlig-frivillig samarbeid, og de illustrerer kompleksiteten i selvhjelpsorganisasjonens relasjoner til fagpersoner og myndigheter på lokalt og regionalt nivå. Nærstudiene viser ulike sider av selvhjelpsorganisasjonens hybriditet og grensearbeid.

Kapitlene 4 og 5 analyserer samarbeidsprosessen mellom Norsk selvhjelpsforum og Selvhjelp Norge og henholdsvis en gruppe fagpersoner i det regionale tjenesteapparatet og en kommuneledelse, for å opprette et regionalt distriktskontor underlagt det nasjonale kompetansesenteret. Kapitlene 6 og 7 viser hvordan Norsk selvhjelpsforum og Selvhjelp Norge 
på litt ulike måter var engasjert i prosessen med å etablere et selvhjelpshus (LINK) i to kommuner, i det ene tilfellet som en støttespiller for en lokal sosial entreprenør, i det andre tilfellet som initiativtaker og tilrettelegger.

«Selvhjelp» kan i alle eksemplene forstås som et grenseobjekt (Star \& Griesemer, 1989), det vil si noe som ulike aktører har en felles målsetting om å realisere, samtidig som de kan ha ulike tolkninger av hva det inneholder. Selvhjelp Norge eller moderstiftelsen Norsk selvhjelpsforum opptrer som aktører, men i nokså forskjellige roller i disse eksemplene. I den rurale nord-norske kommunen opptrer Selvhjelp Norge i bakgrunnen som støttespiller for en lokal entreprenør som samtidig er helt på linje med Selvhjelp Norge ideologisk. I den langt større bykommunen i Midt-Norge er Selvhjelp Norge en sentral premissgiver som får stor innflytelse på hvilke spilleregler som skal gjelde for den kommunalt støttede delen av selvhjelpsfeltet. Ettersom distriktskontorene er noe som driftes direkte av Selvhjelp Norge, blir de direkte aktør og forhandlings- og senere samarbeidspartner, med nettverket av fagpersoner i den ene regionen, og helse- og sosialledelsen i en mellomstor bykommune i den andre regionen. Selvhjelp Norge driver i alle tilfellene en form for «megling» og «oversettelsesarbeid» mellom aktørfelt som vanligvis er holdt separate. Vi forstår denne virksomheten som et grensearbeid fordi det skapes noe nytt på tvers av tradisjonelle grenser samtidig som det tegnes opp nye grenser mellom aktørfeltene.

I den lille kommunen blir grensearbeidet kanskje tydeligst når entreprenøren, etter rådslagning med en sentral ressursperson i Selvhjelp Norge, presiserer det lokale selvhjelpshusets målsetting og målgruppe. Siden det på dette tidspunktet ikke var noe regionalt distriktskontor i landsdelen, skjedde kontakten direkte med den nasjonale lederen for Selvhjelp Norge i Oslo. Entreprenøren og ressurspersonen holder et foredrag på et folkemøte der det understrekes at «man må ha et problem». Lokale bygdefolk som hittil hadde vanket på huset for å ta en kopp kaffe og «slarve» sammen uten noen egentlig intensjon om å begynne med gruppebasert selvutvikling, forstod at de ikke var i målgruppa og sluttet. En grense var blitt trukket, det var ikke til å ta feil av. Budskapet på det åpne folkemøtet ble videreformidlet gjennom oppslaget i lokalavisa med tittelen «Du må ha et problem!». 
Det var Selvhjelp Norges regionale distriktskontor selv som inviterte til dialogmøte om et selvhjelpshus i den store bykommunen, og de inviterte var ulike humanitære/bruker-organisasjoner. Distriktskontoret hadde både relasjon til staten som finansierte driften, og til bykommunen, som de visste var interessert i å støtte et lokalt selvhjelpshus. Med henvisning til den statlige Nasjonal plan for selvhjelp, og med støtte fra de aktuelle faginstanser i kommuneledelsen, fastsatte de premisser for det fremtidige selvhjelpshuset som i realiteten innsnevret definisjonen av selvhjelp. Mange av de inviterte, og i utgangspunktet interesserte, organisasjonene drev med selvhjelpsaktiviteter som ville falle utenfor definisjonen. Konsekvensen var at de trakk seg fra samarbeidet og anbudskonkurransen om å drifte selvhjelpshuset. Også her ble det trukket en grense, huset var ikke ment for likepersonsledete selvhjelpsgrupper, og det skulle heller ikke brukes til interessepolitikk på vegne av ulike brukergrupper.

Samarbeidet rundt opprettelsen av et distriktskontor i Sørøst-Norge belyser en annen grenseflate, nemlig mellom erfaringskunnskap og fagkunnskap. I denne prosessen møttes en selvhjelpsorganisasjon, som fronter «ren» erfaringskunnskap, og ansatte i offentlige tjenester som i dette tilfellet representerer både fagkunnskap og erfaringskunnskap. Det ga partene sterkt overlapp i kunnskapsforståelse og felles interesse i å få i gang selvhjelpsgrupper.

Et spesielt utgangspunkt her var at det i hovedsak var fagpersoner som utgjorde de lokale "frivillige», og de var allerede organisert i et eget samarbeidsforum. Det ga dem en sterk og samlet posisjon som kan ha utfordret Selvhjelp Norge. Kompetansesenteret var opptatt av å løfte frem erfaringskompetanse, både gruppedeltakernes egen og den som selvhjelpsorganisasjonen selv hadde akkumulert og formulert $\mathrm{i}$ sine bøker, brosjyrer og nettsider. Selvhjelp Norge var også opptatt av å avgrense sin forståelse av selvhjelp tydelig fra ledete samtalegrupper og ulike kurs som var blitt en viktig del av lærings- og mestringssentrenes tilbud.

Det var altså krefter i regionen som stod klare til å sette i gang selvhjelpsarbeid, Selvhjelp Norge kom til «et dekket bord», men så ble det $i$ en periode likevel stans i prosessen. I regionen ble utsettingen tolket 
som uttrykk for en skepsis til deres rolle. Det var til dels uklart for dem hvorfor den skulle være problematisk. Etter hvert forstod de det slik at dette kunne knyttes til deres rolle som representanter for helseapparatet. Signalene fra Selvhjelp Norge sentralt i denne perioden (2009-2010) var en stadig sterkere presisering av at selvhjelpsgrupper skulle defineres som «selvorganiserte», det vil si lederløse, tydelig avgrenset fra offentlige helse- og sosialtjenester og uten elementer av kurs eller opplæring. Det ble også formidlet at selvhjelpsgrupper gjerne kunne dannes «på tvers» av ulike diagnoser og problemtyper. Det ble presisert at grupper skulle være orientert mot bearbeiding av personlige problemer, og ikke blandes med sosiale aktiviteter. Det ble dermed lagt føringer og formidlet en definisjon av selvhjelp som Lærings- og mestringssentrene oppfattet som lite fleksibel. De oppfattet Selvhjelp Norges eierskap til, og avgrensing av, selvhjelpsbegrepet som problematisk. For dem var selvhjelp ett av mange redskap i en rikholdig verktøykasse, mens Selvhjelp Norge formidlet at selvhjelp måtte holdes atskilt fra og ikke blandes med lærings- og mestringssentrenes øvrige tilbud.

Da planleggingen av distriktskontoret for innlandsregionen ble startet opp, var det ledelsen i vertskommunen, en mellomstor by, som ble den nasjonale selvhjelpsaktørens samarbeids- og forhandlingspart. I denne casen var det formelt sett Norsk selvhjelpsforum, moderorganisasjonen til Selvhjelp Norge, som forhandlet med bykommunen. I tillegg til å etablere et distriktskontor drevet av Selvhjelp Norge var målsettingen å få opprettet et kommunalt driftet selvhjelpshus (LINK). Selvhjelpssatsingen bidro til å utfylle de kommunale planene slik at de oppfyller statlige føringer om forebygging, ansvar for egen helse og samarbeid med frivillig sektor. Studien viser at selvhjelpsarbeidet, slik det defineres av Norsk selvhjelpsforum blir av bykommunen tolket som en forlengelse av de offentlige tjenestene. Siden den nye formen for selvhjelp som bringes inn, ikke defineres tydelig innenfor frivillig sektor, men blir en mellomting, karakteriserer vi denne satsingen som et grenseobjekt.

Distriktskontoret som etter hvert blir etablert, får en uklar relasjon til de utførende i helse- og sosialtjenestene så vel som til den lokale frivilligsentralen og brukerorganisasjonene. Det blir opprettet et lokalt LINK 
som ett prøveprosjekt, men kommunen strever med å finne lokale partnere for samlokalisering. Symptomatisk, kanskje, så blir ikke det nye selvhjelpshuset samlokalisert med Frivilligsentralen, som fra før huser selvhjelpsgrupper initiert av lokale brukerorganisasjoner og selvhjelpsaktører som Angstringen. De er først samlokalisert med kommunale rehabiliteringstjenester og senere med psykiske helsetjenester. I dette tilfellet er det sannsynligvis andre aktører som trekker opp grenser for dem, grenser som i realiteten hindrer selvhjelpsorganisasjonen i å etablere en fullverdig posisjon i det lokale selvhjelpsfeltet og i å nå ut til den intenderte målgruppen.

De lokale eksemplene viser hvordan Norsk selvhjelpsforum og Selvhjelp Norge må forholde seg til ulike aktører og posisjonere sitt lokale organisasjonsledd innenfor et lokalt selvhjelpsfelt, helse- og velferdsfelt, lokalpolitisk felt osv. Selvhjelp Norge rendyrker visse sider ved sin modell for selvhjelpsgrupper (se kapittel 2), men er pragmatisk når det gjelder politisk og faglig myndighetssamarbeid med sikte på å få økonomisk støtte og legitimitet. Vi reiser derfor et spørsmål om Selvhjelp Norge ikke bare er en grenseoverskridende organisasjon, men en organisasjon som nettopp har sitt eksistensgrunnlag i dette grenselandet - mellom sivilsamfunnet og statlige myndigheter.

\section{Grensearbeid - mellom sivilsamfunn og velferdsstat}

I en interessant antologi, om det norske sivilsamfunnet som hovedcase, karakteriserer Enjolras og Strømsnes (2018) de skandinaviske sivilsamfunn som brede fordi de har en bred folkelig deltakelse. Dette kontrasterer forskerne med det de omtaler som aktive Anglo-amerikanske og smale sør-europeiske former for sivilsamfunnsorganisering. Utover bred deltakelse gjerne målt i form av medlemskap, kjennetegnes de skandinaviske sivilsamfunnsorganisasjoner ved at de har en hierarkisk organisasjonsmodell, bygget opp nedenfra med lokale, regionale og nasjonale avdelinger, og sist, men ikke minst er de statsvennlige. Disse tre kriteriene skiller altså mellom sivilsamfunnets relasjon til den enkelte borger (som medlem eller deltaker i en organisasjon), til lokalsamfunnet (organisert 
etter en 'bottom up' hierarkisk struktur) og i dets relasjon til staten. Vi vil nå diskutere i hvilken grad selvhjelpsaktivismen i regi av Norsk selvhjelpsforum og Selvhjelp Norge (jf kapitlene 2-7) kan sies å være en typisk representant for det norske sivilsamfunnet.

Det første kriteriet er bred folkelig deltakelse i form av medlemskap i en organisasjon. Verken Selvhjelp Norge eller stiftelsen Norsk selvhjelpsforum, som har ansvar for driften av Selvhjelp Norge, har medlemmer. Norsk selvhjelpsforum består i dag av en håndfull personer med bred erfaring og mye kunnskap om selvhjelpsarbeid og psykisk helsearbeid. Organisasjonen har et styre på fem personer: en fagperson fra Helsedirektoratet, en lege og psykiater som arbeider i helsevesenet, en person fra forsikringsbransjen og en management-utdannet person fra høyere privat utdanning, mens styreleder er helseutdannet og er en av initiativtakerne til både forumet og Selvhjelp Norge. Norsk selvhjelpsforum, Nasjonal plan for selvhjelp og Selvhjelp Norge ble alle initiert av personer som vi omtaler som sosiale entreprenører. I den perioden vår studie pågikk (fra 2009 til 2015), var de to sentrale sosiale entreprenørene med i stiftelsens styre og ansatt ved kompetansesenteret, mens de i dag har valgt å ikke lenger inneha disse posisjonene. Selvhjelp Norge er fortsatt et nasjonalt kompetansesenter, med en rekke ansatte fagpersoner med ulik utdanningsbakgrunn og variert erfaringskunnskap.

Vi har beskrevet økende individualisering i samfunnet som en av drivkreftene bak den nye selvhjelpsbevegelsen (jf. kapittel 1 og 2). Som samfunnsborgere utsettes vi for krav om mer selvkontroll og ansvar for eget liv, egen familie og egen helse. Dette er trekk som ofte forbindes med det senmoderne samfunn (Rose, 2006, Taylor \& Leitz, 2010). Eimhjellen med flere (2018) argumenterer for at en pågående individualiseringsprosess har endret det sosiale båndet mellom den individuelle borger og sivilsamfunnets organisasjoner. De antyder at dette båndet endres når medlemskap i organisasjoner går ned. Dette har skapt flere «ad hoc-frivillige» og det har også ført til at færre tar del i de demokratiske prosessene i det sivile organisasjonsliv. Det har altså skjedd en vekst i uformelt og mer kortvarig frivillig arbeid og det har skjedd en vekst av mindre demokratisk sivilsamfunnsorganisering (Eimhjellen et al., 2018). 
Dette er bakgrunnen for at vi karakteriserer Norsk selvhjelpsforum og Selvhjelp Norge som atypiske representanter for det norske sivilsamfunnet, og, vil vi tilføye, de har en atypisk relasjon til den enkelte borger og dermed sivilsamfunnet. Samtidig sier de selv at deres primære oppgave er informasjon og opplæring både nasjonalt og lokalt, de driver altså en type opplysningsprosjekt overfor befolkningen (jf. kapittel 5).

Ser vi på det andre generelle trekket ved norske sivile organisasjoner, skriver Enjolras og Strømsnes (2018) at har de en hierarkisk ofte tredelt organisering fra lokalt til nasjonalt nivå. Denne organiseringen og dets utspring i det lokale er heller ikke Norsk selvhjelpsforum og Selvhjelp Norge typiske eksempel på. Norsk selvhjelpsforum kan omtales som en nasjonal organisasjon, mens Selvhjelp Norge er et nasjonalt kompetansesenter med distriktskontorer som samarbeider med ulike regionale og lokale aktører. Selvhjelp Norge er et nasjonalt anliggende, initiert av Norsk selvhjelpsforum sammen med de nasjonale helsemyndighetene. I den grad Selvhjelp Norge har et lokalt nivå, er det i samarbeid med lokale organisasjoner om lokale møteplasser eller selvhjelpshus (LINK-er). For å oppsummere fremstår verken Norsk selvhjelpsforum eller Selvhjelp Norge som typiske representanter for sivilsamfunnets organisasjonsform i Norge. De har verken en bred representasjon eller deltakelse fra befolkningen eller en organiserende struktur som er bygget opp i en sammenhengende struktur fra lokalt til nasjonalt nivå.

Det siste kjennetegnet ved den norske sivilsamfunnsmodellen som Enjolras og Strømsnes (2018) fremhever, er statsvennlighet. I likhet med andre nordiske land har Norge lange tradisjoner for å samarbeide nært med statlige myndigheter (Enjolras \& Strømsnes, 2018; Trägårdh, 1997; Trägårdh, Selle, Henriksen \& Hallin, 2013). Dette viser seg blant annet ved at stat og kommune integrerer initiativ og ordninger som er utviklet av sivilsamfunnsaktører (se for eksempel Norske kvinners sanitetsforening, 1971; Stefansen, 2006). Vi kan si at frivilligheten i Norge kjennetegnes av statsvennlighet (se for eksempel Enjolras \& Strømsnes, 2018; Trägårdh et al., 2013). Ulike sivilsamfunnsaktører, som for eksempel interesse- og brukerorganisasjoner, vender seg gjerne til staten for å finansiere sin virksomhet, og påtar seg også oppgaver på vegne av det offentlige. Dette medfører en annen form for hybriditet, nemlig det at organisasjoner tar 
opp i seg elementer fra flere ulike former for sosial organisering (Gidron, 2005; Pestoff, 2014). Vi vil argumentere for at Norsk selvhjelpsforum i sterkere grad tilpasser sin virksomhet overordnede nasjonale målsettinger enn det som har vært vanlig for sivile og frivillige organisasjoner. De søker primært om offentlige midler for å organisere og informere om selvhjelpsgrupper overfor profesjoner, offentlige aktører, frivillige organisasjoner og befolkningen som helhet.

Vi argumenterer for at selvhjelpsarbeidet beveger seg gjennom ulike stadier av politisering, og at Norsk selvhjelpsforum har vært en aktiv pådriver i denne prosessen. Over tid har selvhjelp som tema beveget seg fra å være et grasrotinitiativ i form av en selvhjelpsgruppe i egne private omgivelser til et tema på stortingets talestol (jf. kapitlene 1 og 3). Denne prosessen har flere likhetstrekk med utviklingen av andre sosiale bevegelser (se for eksempel Pope, 2003). Et spørsmål er hvor langt denne utviklingen går, før vi kan si at selvhjelpsarbeidet ikke lenger står utenfor, men snarere er integrert i staten.

Det å produsere tjenester sammen med myndighetene er et trekk ved de aktive sivile samfunn og noe som kan knyttes til angloamerikanske land. Norsk selvhjelpsforum samproduserer ikke med myndighetene om levering av tradisjonelle velferdstjenester, men supplerer med tiltak som de statlige helsemyndighetene ikke leverer. Dette kan være en indikasjon på en bevegelse i retning av den angloamerikanske modellen (jf. Salamon, 1987), og vekk fra den nordiske modellen.

De tradisjonelle norske frivillige organisasjonene er medlemsbaserte med en demokratisk struktur som rekrutterer bredt i befolkningen. Dette betrakter Eimhjellen med flere (2018) som en nøkkelfaktor for å opprettholde det norske demokratiet. Den nye trenden, med mindre brede og demokratiske sivile aktører, er interessant å vurdere i lys av den selvhjelpsaktøren som vi studerer i denne antologien. Vi argumenterer for at det har skjedd en økende individualisering og politisering av kollektive handlinger, og at sammenkoblingen mellom Norsk selvhjelpsforum og staten er en interessant case i denne sammenheng (jf. vårt innledende kapittel).

Det vi har identifisert i vår studie, er at Norsk selvhjelpsforum tilpasser seg ulike politiske satsingsområder, først frivillig arbeid, dernest psykisk 
helse og tilslutt folkehelsepolitikk. Norsk selvhjelpsforum og Selvhjelp Norge knytter seg til politiske mål for å fremme selvhjelp, snarere enn å introdusere selvhjelp som metode for å nå egne politiske mål. Dette er bakgrunnen for at vi har karakterisert dem som representanter for den nye selvhjelpsbevegelsen i Norge.

\section{Selvhjelpsarbeid som ledd $\mathrm{i}$ en sosial helse bevegelse?}

I 1993 konkluderte Katz med at den amerikanske selvhjelpsbevegelsen ikke er en sosial bevegelse (Katz, 1993). Han legger til grunn at noen selvhjelpsorganisasjoner, først og fremst 12-trinnsbevegelsen, kan forstås som varianter av sosiale bevegelser, men at selvhjelpsfeltet som helhet er mer å regne som en sosial trend enn en sosial bevegelse. Begrunnelsen er at selvhjelpsfeltet i liten grad har samlet seg om felles verdier, overbevisninger eller solidaritet, og at det derfor ikke utgjør en samordnet politisk kraft. De siste tiårene har vi imidlertid sett en økt oppmerksomhet om og forståelse for betydning av selvhjelpsgrupper for identitets- og opinionsdannelse (Archibald, 2010; Taylor \& Leitz, 2010). Vi mener derfor det er grunnlag for å reise spørsmålet om selvhjelp som sosial bevegelse på nytt. Kan den norske selvhjelpsbevegelsen sies å utgjøre del av en sosial bevegelse eller en helsebevegelse, og hvilke tema er den i så fall organisert rundt?

I likhet med andre land finner vi i Norge rene selvhjelpsgrupper og -organisasjoner, som for eksempel AA og andre 12-trinnsgrupper, i tillegg til bruker- og interesseorganisasjoner som har etablert selvhjelp og selvhjelpsrelaterte aktiviteter til sine medlemmer. Mye av dette arbeidet har vært rettet mot spesifikke diagnoser eller livsproblemer, enten det dreier seg om sykdom og diagnoser (f.eks. Brystkreftforeningen, IKS, Vårres), skade (f.eks. Personskadeforbundet/LTN), traumer (f.eks. Støttesenter mot incest, Landsforeningen Uventet Barnedød), pårørendeproblematikk (f.eks. Al-Anon), fattigdom (f.eks. Velferdsalliansen). ${ }^{1}$ Det er,

1 Forkortelsen IKS står for Interessegruppa for kvinner med spiseforstyrrelser (nå Spiseforstyrrelsesforeningen), Vårres er et regionalt brukerstyrt senter for psykisk syke, Personskadeforbundet/ LTN het tidligere Landsforeningen for trafikkskadde. Al-Anon er navnet på pårørendegruppa til alkoholikere og andre med avhengighetsproblematikk. 
med andre ord, stor variasjon i hvilke problemer selvhjelpsgruppene er ment å håndtere. Betyr dette at de, som Katz (1993) påpeker, ikke kan sies å ha samlet seg om felles verdier, overbevisninger eller solidaritet?

Er Selvhjelp Norges modell i konflikt med rådende oppfatninger av hva en selvhjelpsgruppe er? Den svenske forskeren Karlsson definerer en selvhjelpsgruppe slik: «En självhjelpsgrupp är en mindre, deltagarstyrd samling av människor som regelbundet träffas för at bearbeta gemensamma problem genom ömsesidig stöd och hjälp» (Karlsson, 1997, s. 45).

Det kan diskuteres hva som skal legges i uttrykket «felles problem». Karlsson har gjennomgått internasjonal litteratur om selvhjelpsgrupper og blant annet sett på ulike definisjoner av dette fenomenet. Deltakere med et «felles problem» er det mest sentrale kriteriet for å kalle noe en selvhjelpsgruppe (Karlsson, 1997, s. 44). Mange vil nok si at Selvhjelp Norges idé om å danne grupper «på tvers» av problem klart bryter med denne betingelsen. På den annen side kan man argumentere for at de individuelle utfordringene $\mathrm{i}$ en diagnosesammensatt gruppe aldri er helt like. Man kan også argumentere for at utfordringen det er å skulle mestre å bearbeide en negativ og destruktiv selvfølelse er sammenlignbart og gjenkjennbart uavhengig av hva det var som fremkalte livskrisen.

Hvordan opplever deltakere å delta i grupper "på tvers»? Det er et interessant empirisk spørsmål som foreløpig er lite utforsket. Vi har intervjuet enkelte deltakere som har erfaring med slike grupper (kapittel 2), og som hevder at de har hatt utbytte av gruppen selv om andre deltakere har andre problemtyper. ${ }^{2}$ Selvhjelp Norge (intervju med leder) viser til at oppgaven med å mestre sitt eget problem er sammenlignbar med de andres og at det spesifikke problemet som skapte den vanskelige livssituasjonen, ikke behøver å stå i fokus. I en bok skrevet to ledende personer ved Selvhjelp Norge gjengis en uttalelse fra en gruppedeltaker: «(D) et er det samme hva navnet på problemet vårt er. Det er alle de følelsene som ligger bak problemene vi kjenner oss igjen i, og som vi kan dele våre erfaringer på» (Godager \& Talseth, 2013, s. 92). Vi har imidlertid for tynt empirisk materiale til å trekke noen konklusjoner ut fra dette.

2 Et pågående doktorgradsarbeid ved Universitetet i Oslo, Institutt for sosialantropologi, ventes å bringe frem ny innsikt om slike grupper (Gotaas u.a). 
Som vi har beskrevet (i kapitlene 3 og 7), samlet en rekke selvhjelpsaktører seg på 1990-tallet for å diskutere mulighet for tettere samarbeid. Organisasjoner og aktører møttes på selvhjelpskonferanser for å diskutere selvhjelp som idé, tilnærming og metode, samt mulighetene for tettere samarbeid mellom aktørene på feltet. Sosialpsykologi, myndiggjøring (empowerment) og grensedragningen mellom stat og sivilsamfunn ga et felles grunnlag for aktører som rettet sin aktivitet mot veldig ulike grupper. Over tid er det også blitt tydeligere at selvhjelpsaktiviteten $i$ all hovedsak er rettet mot individet. Selv om vi kan finne eksempler på aktører som har sosial marginalisering som et hovedanliggende, ser vi allerede på 1990-tallet et økende antall individ- og helseorienterte grupper og organisasjoner. I dag fremstår helse i vid forstand som et hovedanliggende i det vi omtaler som den nye selvhjelpsbevegelsen. Som vi viser i kapittel 3 , har Nasjonal plan for selvhjelp knyttet selvhjelp eksplisitt til både psykisk helsearbeid og til folkehelsearbeid. Vi ser også at flere organisasjoner, som for eksempel Angstringen, Støttesenter mot incest, Interessegruppa for kvinner med spiseforstyrrelser, Landsforeningen uventet barnedød og Personskadeforeningen tar utgangspunkt i individuelle og kroppsliggjorte erfaringer $i$ arbeidet for individuelle endringsprosesser og for endringer $i$ behandlingsapparatets og offentlige myndigheters innstilling og respons.

Selv om Nasjonal plan for selvhjelp uttrykte en ambisjon om å knytte nettverk med bruker- og interesseorganisasjoner, har det i praksis vist seg vanskelig å engasjere organisasjonene i dette arbeidet. På tross av at myndiggjøring, helseforståelse og selvhjelp peker seg ut som mulige felles prosjekt, viser våre casestudier at organisasjonene i større grad har valgt å engasjere seg i samarbeid med aktører som arbeider innenfor samme problemfelt, for eksempel rusomsorg, psykisk helse eller bestemte diagnoser. I likhet med amerikanske selvhjelpsorganisasjoner på 1990-tallet har ikke norske selvhjelpsorganisasjoner på 200o-tallet samlet seg om en felles sak, og utgjør ikke en samordnet sosial kraft.

Hva så med Norsk selvhjelpsforum, kan vi forstå denne organisasjonen som del av en sosial helsebevegelse? Norsk selvhjelpsforum har vært en sentral aktør i utviklingen av det norske selvhjelpsfeltet de siste 30 årene. I samarbeid med Helsedirektoratet har de arbeidet frem og senere revidert Nasjonal plan for selvhjelp. Målet har ikke bare vært å sette selvhjelp 
på dagsordenen, men å sikre at alle i Norge vet hva selvhjelp er og kan ta metoden i bruk ved behov (Helsedirektoratet, 2014). Norsk selvhjelpsforum har således likhetstrekk med helsebevegelser, slik de beskrives av Brown og kolleger (2004). Dette er bevegelser som vektlegger personlige erfaringer med sykdom eller funksjonsnedsettelser, utfordrer den medisinske forståelsen av sykdom og gjerne legger opp til samarbeid mellom aktivister og helsepersonell om behandling, forebygging, forskning og finansiering (Brown et al., 2004). De fokuserer på erfaringer, identitet og bevisstgjøring som grunnlag for handling (Archibald, 2010; Snow \& Benford, 1988; Taylor \& Leitz, 2010), de utfordrer eksisterende medisinsk og vitenskapelig kunnskap, og de engasjerer gjerne eksperter og profesjoner i kampen for anerkjennelse og behandlingstilbud (Brown \& Zavestoski, 2005; Brown et al., 2004).

Hybriditet er et kjennetegn ved denne type bevegelser (Archibald, 2010; Brown et al., 2004; Gidron, 2005). Norsk selvhjelpsforum og Selvhjelp Norge har to trekk som vi gjenkjenner fra litteraturen om helsebevegelser (Archibald, 2010; Brown et al., 2004). For det første foretar de en sammenkobling av ekspert- og lekkunnskap (Archibald, 2010; Brown \& Zavestoski, 2005; Brown et al., 2004). For det andre utfordrer og søker Norsk selvhjelpsforum og Selvhjelp Norge anerkjennelse fra medisinen og helseprofesjonene. I denne formen for hybriditet ligger det at fremgangsrike selvhjelpsorganisasjoner henter legitimitet fra flere ulike kilder, fra helsevesenet og profesjonene, fra akademia og forskning, fra politikken og strømninger i opinionen. Motsatt vil organisasjoner som ikke lykkes i å mobilisere støtte fra innflytelsesrike partnere, bidra til å svekke kraften i kollektive bevegelser (Archibald, 2010). Dette kan være en forklaring på at Norsk selvhjelpsforum vender seg mot staten, behandlingsapparatet og profesjonene. På denne bakgrunn kan vi forstå Norsk selvhjelpsforum som en ny retning innenfor selvhjelpsbevegelsen.

\section{En atypisk selvhjelpsaktør - spenninger i norsk selvhjelpsbevegelse}

Selvhjelp Norge og Norsk selvhjelpsforum promoterer en selvhjelpsgruppemodell som kan sies å være mer terapeutisk og personorientert enn 
andre selvhjelpsorganisasjoner. Det er mange likhetstrekk mellom måten selvhjelpsgrupper som følger denne modellen fungerer på, og psykoterapeutiske behandlingsgrupper. Når det i tillegg argumenteres for å danne grupper på tvers av diagnoser/problemtyper, understreker dette det psykologiske aspektet ved mestring og nedtoner betydningen av kunnskapsdeling og identifikasjon basert på det spesifikke problemet. Det gjør det også vanskeligere å bruke gruppen som basis for rettighetskamp og politisk arbeid.

Selvhjelp Norge og Norsk selvhjelpsforum er tydelige på at de ikke vil drive interessepolitikk for bestemte brukergrupper eller arbeide for samfunnsendringer. Den sentrale ledelsen har imidlertid spilt en politisk rolle. For det første har Norsk selvhjelpsforum på et tidlig tidspunkt inngått et samarbeid med myndighetene som i praksis innebærer at en frivillig organisasjon gjør felles sak med staten. Deltakelse i myndighetenes planarbeid og en ekspertrolle i forhold til den statlige tilskuddsordningen for selvhjelpsprosjekter og forskning på selvhjelp indikerer at Norsk selvhjelpsforum har deltatt i en samstyring («governance») av selvhjelpsfeltet (Vabo \& Røiseland, 2008).

Norsk selvhjelpsforum og Selvhjelp Norge fremstiller seg selv som et talerør for selvhjelpsbevegelsen med innflytelse på myndighetenes politikkutforming på feltet. På den annen side kan de også oppfattes som statens forlengede arm inn i selvhjelpsfeltet og som representanter for statlig styring. Begge deler kan være riktig, og dette illustrerer den hybride organisasjonen. Organisasjonene representerer i seg selv spenningen mellom å være frivillig organisasjon og å være del av staten. Rollen de har spilt som nasjonal selvhjelpsaktør i utviklingen av selvhjelpsfeltet på 20oo-tallet, viser også andre spenninger. De lokale casene vi har studert, har vist spenningen mellom lokal kultur og selvhjelpsgrupper som en ny type sosial praksis, mellom fagmiljøenes og den nasjonale selvhjelpsaktørens forvaltning av erfaringskunnskapen, og mellom den nasjonale selvhjelpsaktøren og lokale aktører som kommunen og andre frivillige organisasjoner. Samtidig illustrerer de lokale casene også spenninger vi vil anta at har en mer generell karakter og springer ut av selvhjelpsarbeidets grenseoverskridende karakter.

Vi ser konturene av en ny type sosial helsebevegelse (Archibald, 2010; Brown et al., 2004). Selv om de spesifikke diagnosene nedtones, så gis 
det likevel stor oppmerksomhet til kroppslige og psykiske opplevelser og emosjonelle reaksjoner på egen livssituasjon (embodiment). Selvhjelp Norge refererer ofte til en norsk psykoterapeut som har skrevet om «symptomet som ressurs» (Axelsen, 1997), og som vektlegger hvordan kroppslige signaler kan tolkes og vise vei mot en løsning av problemene. Selvhjelpsgruppenes arbeid kan i stor grad beskrives som bearbeiding og refortolkning av negative følelser med sikte på økt psykologisk selvinnsikt og bedret selvfølelse (Taylor \& Leitz, 2010). Personlige erfaringer med ulike livskriser i form av alvorlige psykiske og/eller sosiale problemer er rekrutteringsgrunnlag. Kronisk sykdom eller fysiske funksjonshemninger kan godt være utgangspunktet, men fokuset er lagt på de psykososiale utfordringene en slik livssituasjon skaper. Terminologien er flyttet bort fra de spesifikke diagnosene og over til mer generaliserte begreper om selvutvikling, mestring og forebygging. Det samfunnskritiske potensialet som man ellers forbinder med sosiale bevegelser er, som nevnt, ikke like åpenbart i denne nye retningen for selvhjelp (Archibald, 2010; Brown \& Zavestoski, 2005). Siden det også finnes pasient- og brukerorganisasjoner som har en tydelig interessepolitisk dagsorden, kan det tenkes at det har skjedd en arbeidsdeling her: at den nasjonale selvhjelpsaktøren overlater den samfunnskritiske funksjonen til andre organisasjoner.

Selvhjelpsgrupper som fenomen blir imidlertid også politisk ved at det skjer en organisering rundt gruppene med formål om bedre tilrettelegging, større utbredelse og allmenn informasjon. Selvhjelp Norge er involvert i dette på lokalt nivå, ved etablering av et LINK eller et distriktskontor, eventuelt når det lages samarbeidsavtaler med andre lokale aktører som ønsker å bruke deres kompetanse. På nasjonalt nivå er Selvhjelp Norge regelrett en integrert del av statens helse- og velferdspolitikk. Denne politiseringen (se også kapittel 3) innebærer at selvhjelp blir gitt politisk og faglig legitimitet og tilgang til offentlige støtteordninger. Selvhjelpsgrupper har også blitt synliggjort gjennom samarbeid og finansiell støtte fra myndighetene, noe som kan ha hatt effekt på opinionsdannelsen. Det kan innebære større sosial og kulturell anerkjennelse av gruppedeltakere som i utgangspunktet har opplevd seg selv som marginaliserte og stigmatiserte (Archibald, 2010; Taylor \& Leitz, 2010). 
Verken Norsk selvhjelpsforum eller Selvhjelp Norge har som nevnt en medlemsbase. Vi har derfor ikke å gjøre med en demokratisk organisasjon som kan sammenlignes med andre frivillige organisasjoner i Norge. Den er heller ikke bygget opp hierarkisk med lokale, regionale ledd og et sentralt organ på toppen. Selvhjelp Norge har riktignok bygget ut et nettverk av regionale distriktskontorer, men disse er en forlengelse av det sentrale leddet og fungerer omtrent som lokalavdelinger i en bedrift. Denne organisasjonsformen er dermed utradisjonell, men ikke enestående. ${ }^{3}$ Norsk selvhjelpsforum og Selvhjelp Norge står i lang skandinavisk tradisjon når det gjelder å ha et tillitsfullt forhold til staten (Enjolras \& Strømsnes, 2018).

Selvhjelp Norge utøver grensearbeid i rommet mellom sivilsamfunnet og staten, en virksomhet som har hatt åpenbare gevinster, men som også kan ha hatt sine omkostninger. Når staten blir en alliert, kan man få større gjennomslag og nå lenger ut med opplysningsarbeidet, men det gir mindre mulighet for samfunnskritikk. Når Norsk selvhjelpsforum får utforme innholdet $\mathrm{i}$ et viktig styringsdokument, er det vanskeligere for dem å kritisere den nasjonale planen i etterkant. Man blir mer bundet ved å delta i en slik form for samstyring som for øvrig beskrives som en trend («governmentality») i den vestlige velferdsstatsutviklingen (Høgsbro, 2010). Det kan også gi økt sjanse for gjennomslag ved å tilpasse seg til skiftende politiske satsinger på et mer overordnet plan, for eksempel satsingen på psykisk helse, som etter en stund ble avløst av en stor folkehelsesatsing. Ulempene kan imidlertid være, som den amerikanske forskeren Archibald skriver, at det skjer en målforskyvning, at organisasjonens formål blir kooptert av den sterkere alliansepartneren og følgelig at tilhengerne blir skuffet og desillusjonerte (Archibald, 2010, s. 243).

Betraktet fra myndighetenes side så kan Norsk selvhjelpsforum være en bortimot ideell partner. Samhandlingsreformen, som innebar en stor delegering av oppgaver og ansvar til lavere administrative nivåer hadde en tilleggsmålsetting om et mer omfattende samarbeid med sivilsamfunnet. Det som ble kalt «den andre samhandlingsreformen» (NOU 2011:11) kan også tolkes som en overføring av ansvar til borgerne og til de frivillige

3 Innenfor miljøvernområdet har vi for eksempel en lignende stiftelse i form av Bellona, som ble opprettet av en liten gruppe aktivister og som i dag utvikler kompetanse, overvåker utviklingen og utøver kritikk på miljøvernområdet. 
organisasjonene - ansvar for egen helse og velferdsbehov. Selvhjelp Norges gruppemodell er, i likhet med de andre selvhjelpsorganisasjonenes virksomhet, en sosial teknologi som passer inn i en slik visjon (Foucault, 1991; Hedlund \& Landstad, 2012; Høgsbro, 2010; Lundgren, 2010).

Foucault-inspirerte analyser peker ofte på hvordan statlig makt får nedslag i sivilsamfunn og i borgernes bevissthet gjennom indirekte styringsformer og endringer i hva som fremstår som mulig, det vil si diskursive endringer (Foucault, 1991). Det kan være nyttig å minne om at Foucault ikke betraktet «makt» som noe negativt i seg selv, heller ikke statsmakten. Også Rose og Miller (1992), to viktige representanter for denne forskningstradisjonen, understreker at deres analyser ikke er ment som en normativ kritikk, men en deskriptiv beskrivelse av hvordan velferdsstater styres i senmoderniteten. Selv om staten har en interesse i å flytte mer ansvar for egen helse over på borgerne og la frivilligheten ta en større rolle i velferdsproduksjonen, så kan dette også ha positive elementer sett fra borgernes og organisasjonenes side i form av frihet, mulighet til å agere og påvirke. Norsk selvhjelpsforum og Selvhjelp Norge betrakter samarbeidet med staten som «vellykket» fordi de har forankret selvhjelpsarbeidet politisk og fått sin fortolkning synliggjort i flere politiske dokumenter av sentral betydning. Det betyr at også de har utøvd diskursiv makt, påvirket hvordan politikere og en bredere opinion kan tenke om selvhjelpsgrupper.

Hvordan vil dette utvikle seg videre? Den sterke bindingen til staten har åpenbart styrket selvhjelpssakens legitimitet i profesjonsmiljøer og lokale myndigheter, og påvirket opinionen. Vi må likevel spørre om dette i lengden svekker deres legitimitet på grasrotnivået. Norsk selvhjelpsforum er også sårbare siden de ikke har en demokratisk base i form av medlemmer eller medlemsorganisasjoner. Vi mener allerede å ha observert en sviktende legitimitet og relevans når det gjelder relasjonen til de andre selvhjelpsorganisasjonene samt pasient- og brukerorganisasjonene.

\section{Referanser}

Archibald, M. E. (2007). The evolution of self-help. New York: Palgrave Macmillan. Archibald, M. E. (2010). Sources of self-help movement legitimation. I J. C.

Banaszak-Holl, S. R. Levitsky \& M. N. Zald (Red.), Social movements and the transformation of American health care. Oxford: Oxford University Press. 
Axelsen, E. D. (1997). Symptomet som ressurs: Psykiske problemer og psykoterapi. Oslo: Pax.

Brown, P. \& Zavestoski, S. (2005). Social movements in health: An introduction. I P. Brown \& S. Zavestoski (Red.), Social movements in health. Oxford: Blackwell. Brown, P., Zavestoski, S., McCormick, S., Mayer, B., Morello-Frosch, R. \& Gasior Altman, R. (2004). Embodied health movements: New approaches to social movements in health. Sociology of Health \& Illness, 26(1), 50-80. https://doi.org/ https://doi.org/10.1111/j.1467-9566.2004.00378.x

Diani, M. \& Della Porta, D. (2009). Social movements: An introduction. Hoboken, UK: John Wiley \& Sons, Incorporated.

Eimhjellen, I., Steen-Johnsen, K., Folkestad, B. \& Ødegård, G. (2018). Changing patterns of volunteering and participation. I B. Enjolras \& K. Strømsnes (Red.), Scandinavian civil society and social transformations: The case of Norway (s. 25-65). Cham: Springer International Publishing.

Enjolras, B. \& Strømsnes, K. (2018). The reconfiguration of the Norwegian voluntary sector. I B. Enjolras \& K. Strømsnes (Red.), Scandinavian civil society and social transformations: The Case of Norway (s. 165-185). Cham: Springer International Publishing.

Eyal, G. (2013). For a sociology of expertise: The social origins of the autism epidemic. American Journal of Sociology, 118(4), 863-907. https://doi.org/10.1086/668448

Feiring, M. (2013). Politicisation of self-help in Norway. I L. Nicolaou-Smokoviti, Sünker, Heintz, Rozanova, Julia \& Pekka Economou, Victoria (Red.), Citizenship and social development. Citizen participation and community involvement in social welfare and social policy. Frankfurt am Main: Peter Lang Publishing Group.

Feiring, M. (2019b). Selvhjelpsarbeid - mellom erfaringskunnskap og forskningsbasert kunnskap. I O. P. Askheim, I. M. Lid \& S. Østensjø (Red.), Samproduksjon i forskning. Oslo: Universitetsforlaget.

Foucault, M. (1991). Governmentality. I G. Burchell, C. Gordon \& P. Miller (Red.), The Foucault effect: Studies in governmentality (s. 87-104). Chicago: University of Chicago Press.

Gidron, B. (2005). Understanding multi-purpose hybrid voluntary organizations: The contributions of theories on civil society, social movements and non-profit organizations AU - Hasenfeld, Yeheskel. Journal of Civil Society, 1(2), 97-112. https://doi.org/10.1080/17448680500337350

Gieryn, T. F. (1999). Cultural boundaries of science: Credibility on the line. Chicago: University of Chicago Press.

Godager, E. V. \& Talseth, S. (2013). Selvhjelp. Om å ta tak i eget liv sammen med andre. Falun: $\mathrm{Z}$ Forlag.

Hedlund, M. \& Landstad, B. (2012). The construction of self-help in Norwegian health policy. International Journal of Self Help and Self Care, 6(1), 65-87. 
Helsedirektoratet. (2014). Nasjonal plan for selvhjelp 2014-2018. Oslo: Helsedirektoratet.

Høgsbro, K. (2010, 16-17 September 2010). Social policy and self-help in Denmarka governmentality perspective. Innlegg presentert ved Workshop on Self-Help, Levanger, Norway.

Karlsson, M. (1997). Självhjälpsgrupper i Sverige: En introduktion. Sköndal: Sköndalsinstitutet.

Katz, A. H. (1993). Self-help in America: A social movement perspective. New York: Twayne Publishers.

Klawiter, M. (2008). The biopolitics of breast cancer: Changing cultures of disease and activism. Minneapolis: University of Minnesota Press.

Lundgren, G. V. (2010). Självhjälpens retorik: En Foucaultinspirerad textanalys av Norsk selvhjelpsformums introduktionshäfte Sevlhjelp: En innføring. Oslo: Universitetet i Oslo.

Norske kvinners sanitetsforening. (1971). Norske kvinners sanitetsforening 1946-1971: B. 2: Arbeidsperioden 1946-1971. Oslo: Foreningen.

NOU 2011:11. (2011). Innovasjon i omsorg. Oslo: Helse- og omsorgsdepartementet.

Pestoff, V. (2014). Hybridity, coproduction, and third sector social services in Europe. American Behavioral Scientist, 58(11), 1412-1424. https://doi. org/10.1177/0002764214534670

Pope, C. (2003). Resisting evidence: The study of evidence-based medicine as a contemporary social movement. Health, 7(3), 267-282. https://doi. org/10.1177/1363459303007003002

Rose, N. (2006). Governing «advanced» liberal democracies. I A. Sharma \& A. Gupta (Red.), The anthropology of the state: A reader. Malden, Mass.: Blackwell.

Rose, N. \& Miller, P. (1992). Political power beyond the state: Problematics of government. British Journal of Sociology, 43(2), 173-205.

Salamon, L. M. (1987). Of market failure, voluntary failure, and third-party government: Toward a theory of government-nonprofit relations in the modern welfare state. Journal of Voluntary Action Research, 16(1-2), 29-49. https://doi. org/10.1177/089976408701600104

Snow, D. A. (2004). Social movements as challenges to authoriy: Resistance to an emerging conceptual hegemony. I D. J. Myers \& D. M. Cress (Red.), Authority in Contention (s. 3-25). New York: Elsevier.

Snow, D. A. \& Benford, R. D. (1988). Ideology, frame resonance and movement participation. International Social Movement Research, 1, 197-217.

Star, S. L. \& Griesemer, J. R. (1989). Institutional ecology, 'translations' and boundary objects: Amateurs and professionals in Berkeley's Museum of Vertebrate Zoology, 1907-39. Social Studies of Science, 19(3), 387-420. https://doi. org/10.1177/030631289019003001 
Stefansen, K. (2006). Krisesentrene i Norge - fra sosial bevegelse til profesjonaliserte hjelpetiltak. Nordisk sosialt arbeid, 26(01), 27-37. Hentet fra http://www.idunn.no/ nsa/2006/o1/krisesentrene_i_norge_-_fra_sosial_bevegelse_til_profesjonaliserte_ hjelpeti

Taylor, V. \& Leitz, L. (2010). From infanticide to activism. Emotions and identity in self-help movements. I J. C. Banaszak-Holl, S. R. Levitsky \& M. N. Zald (Red.), Social movements and the transformation of American health care. Oxford: Oxford University Press.

Trägårdh, L. (1997). Statist individualism. I Ø. Sørensen \& B. Stråth (Red.), The cultural construction of Norden. Oslo: Scandinavian University Press.

Trägårdh, L., Selle, P., Henriksen, L. S. \& Hallin, H. (2013). Civilsamhället klämt mellan stat och kapital: Välfärd, mångfald, framtid. Stockholm: SNS förlag.

Vabo, S. I. \& Røiseland, A. (2008). Governance på norsk. Samstyring som empirisk og analytisk fenomen. Norsk statsvitenskapelig tidsskrift, 24(01-02), 86-107.

Valverde, M. (1998). Diseases of the will: Alcohol and the dilemmas of freedom. Cambridge: Cambridge University Press. 


\section{Kort om forfatterne}

Ånund Brottveit er sosialantropolog. Han har skrevet PhD om bruken av åpen dialog teori og sosialt nettverkstilnærming innenfor psykisk helsevern i Norge. I dag er han forskningssjef i KIFO, Institutt for kirke-, religions- og livssynsforskning, og forsker på blant annet religiøst mangfold og tros- og livssynsdialog. anund.brottveit@kifo.no

Marte Feiring er utdannet sosiolog. Hun har skrevet $\mathrm{PhD}$ om den historiske utviklingen av rehabiliteringspraksiser i Norge. I dag er hun førsteamanuensis ved Fakultet for helsefag, Masterprogrammet i rehabilitering og habilitering, OsloMet hvor hun forsker og underviser i rehabilitering, samhandling, brukermedvirkning samt kvalitative forskningsmetoder. marte.feiring@oslomet.no

Nora Gotaas er sosialantropolog og forsker 2 ved By- og regionforskningsinstituttet NIBR - OsloMet. Hun arbeider med kunnskaps- og problemforståelse i forvaltning og sivilsamfunn og ulike former for sosialt arbeid og - entreprenørskap. Gotaas er i ferd med å avslutte en PhD-avhandling om personlig endringsarbeid i selvorganiserte selvhjelpsgrupper, sett i forhold til institusjonelle og kulturelle rammer. nora.gotaas@ oslomet.no

Hilde Hatleskog Zeiner er statsviter med PhD i Politial and Social Studies fra European University i Firenze. Hun arbeider ved By- og regionforskningsinstituttet NIBR - OsloMet hvor hun blant annet forsker på organiseringen av offentlige velferdstjenester, kunnskapsforståelse og organisering av ansvar mellom ulike forvaltningsnivå. hildehatleskog. zeiner@oslomet.no 
